UNIVERSIDADE DE SÃO PAULO

FACULDADE DE ECONOMIA, ADMINISTRAÇÃO E CONTABILIDADE DEPARTAMENTO DE ADMINISTRAÇÃO

PROGRAMA DE PÓS-GRADUAÇÃO EM ADMINISTRAÇÃo

\title{
CAPTAÇÃO DE SINAIS ANTECIPATIVOS NA WEB UTILIZANDO AGENTES INTELIGENTES
}

Ana Helena da Silva Moreira

Orientador: Prof. Dr. Fernando Carvalho de Almeida

SÃO PAULO

2006 
Profa. Dra. Suely Vilela

Reitora da Universidade de São Paulo

Prof. Dr. Carlos Roberto Azzoni

Diretor da Faculdade de Economia, Administração e Contabilidade

Prof. Dr. Isak Kruglianskas

Chefe de Departamento de Administração

Prof. Dr. Lindolfo Galvão de Albuquerque

Coordenador do Programa de Pós-Graduação em Administração 


\title{
CAPTAÇÃO DE SINAIS ANTECIPATIVOS NA WEB UTILIZANDO AGENTES INTELIGENTES
}

\author{
Dissertação apresentada ao Departamento de \\ Administração da Faculdade de Economia, \\ Administração e Contabilidade da \\ Universidade de São Paulo como requisito \\ para a obtenção do título de Mestre em \\ administração.
}

Orientador: Prof. Dr. Fernando Carvalho de Almeida

\section{SÃO PAULO}




\section{FICHA CATALOGRÁFICA}

Elaborada pela Seção de Processamento Técnico do SBD/FEA/USP

Moreira, Ana Helena da Silva

Captação de sinais antecipativos na web utilizando agentes inteligentes

/ Ana Helena da Silva Moreira. -- São Paulo, 2006.

xxx p.

Dissertação (Mestrado) - Universidade de São Paulo, 2006

Bibliografia.

1. Gestão da informação 2. Monitoramento estratégico ambiental

3. Agentes inteligentes I. Universidade de São Paulo. Faculdade de Economia, Administração e Contabilidade II. Título.

CDD - 658.4038 
A meus pais, que sempre me acolheram de braços abertos ao voltar das minhas viagens em frágeis balões coloridos.

A três mulheres maravilhosas, que ainda não fossem minhas irmãs, as admiraria profundamente.

À Nara, Carolina, Francisco, João e Paulo, que me ensinaram o que é amar incondicionalmente.

Ao meu querido cunhado Marcelo, mais ainda, um irmão. 
Existem características das pessoas as quais admiro profundamente: inteligência, justeza, generosidade em ensinar, humildade em aprender; todas elas meu orientador, Prof. Dr. Fernando Carvalho de Almeida, possui. Que prazer foi trabalhar com ele. Agradeço ao Prof. Dr. Ronaldo Zwicker e ao Prof. Dr. Hiroo Takaoka pelos caminhos indicados na qualificação, que abriram outras possibilidades de aprendizado. Não poderia deixar de registrar um agradecimento ao meu eterno professor de coração Prof. Dr. Adolpho W. P. Canton.

Ao Dr. Taki Cordás, por me fazer viver, minha eterna gratidão.

Dizem que todos acham que seu próprio terapeuta e seu próprio cão são os mais brilhantes do mundo. Isso não cabe a mim. Eu não tenho cão e o meu terapeuta é realmente o mais brilhante do mundo. A ele, Dr. Adriano Segal, por me fazer viver mais feliz. Não consigo exprimir meus sentimentos de amizade, confiança e amor.

À minha amiga e mestra Bety Chachamovitz, pelos ensinamentos da vida. Aos meus grandes amigos e incentivadores Cynthia, Ciça, Maria Helena, Marquinhos, Bension, Edu, Kátia, com quem tenho o prazer de conviver há mais de 25 anos e espero que sejam companheiros eternos. Mayra querida, foi amor à primeira conversa. Aos amigos Ana Lúcia e Valentim (precisamos voltar às nossas conversas que percorrem todos os planetas, agora talvez somente por 4 ou 5 horas, já que temos um a menos a percorrer). Aos meus mais recentes amigos Otávio, Ana Carolina, Celina, Ricardo, que se tornem meus amigos de mais de 25 anos de convivência. A outros amigos queridos que não cito nominalmente por total falta de espaço, obrigada por tudo.

Aos meus primos, primas, tios e tias, que o tempo não permite uma maior convivência. Ao meu doce tio Mingo. Aos almoços nos domingos, concedidos bondosamente pela minha mãe, com as presenças da Mônica, tia Graça e Dna. Ednen. Em memória, à minha querida tia Lélia.

À FIAP, por me permitir aprender e ensinar. Aos meus alunos, com quem sempre me relaciono com muito carinho e preocupação de deixar um pouco do que sei. A todos os profissionais da escola, que estão sempre prontos a nos atender com bom humor. Especial agradecimento ao Professor Danúbio, que me deu a oportunidade de iniciar esta aventura. À minha equipe de profissionais excepcionais e amigos, Abrão, Adelaide, Gregório, Kátia, Maritza, Mauri, Regina. Vamos continuar juntos por muito tempo, assim espero.

Por fim, o mais importante. Ao José Manoel e ao André, meu mais profundo afeto, para sempre. 
“... o sagrado instinto de não ter teorias...”

Fernando Pessoa 


\section{RESUMO}

Este trabalho explora uma solução para tornar mais eficiente a recuperação de sinais estratégicos antecipativos na Internet, na chamada fase de rastreamento ou de captação de informação estratégica antecipativa, segundo diferentes autores, que descrevem ciclos da Inteligência Competitiva. Durante o texto a seguir serão descritos os conceitos de Inteligência Competitiva e de agentes inteligentes de software, considerada a solução ideal para suportar a recuperação de informação neste mundo imenso que é a Internet.

Um protótipo será arquitetado para verificar a possibilidade de agentes serem uma boa representação e solução para o rastreamento de informação, com o objetivo de suportar o monitoramento estratégico do ambiente de uma organização. Estas informações, necessariamente, devem ser qualificadas, confiáveis e condizentes com um tema, atores e fontes predeterminados. A forma de obtenção das informações no ambiente Web pode ser feita diretamente e de forma discreta (no tempo) ou contínua, sem que seja acionada uma questão para busca direta, mas em resposta a um evento com características de interesse definidas. 


\begin{abstract}
This work explores a solution to making more efficient the recovery of antecipative strategical signals in the Internet, in the so-called tracking phase or antecipative strategical information captation phase, according to different authors describing cycles of Competitive Intelligence. In the text that follows, the concepts of Competitive Intelligence and intelligent agents of software will be described, considering the ideal solution to support the recovery of information in this immense world that is the Internet.
\end{abstract}

A prototype will be set to verify the possibility of agents being good representation and a solution for the tracking of information, with the objective of supporting the strategical monitoring of an organization's environment. These pieces of information must necessarily be qualified, trustworthy and related to predetermined subject, actors and sources. The attainment of information in the Web environment can be direct and of discrete form (within time constraints) or continuum, without inputting a question for direct search, but in reply to an event with definite characteristics of interest. 


\section{SUMÁRIO}

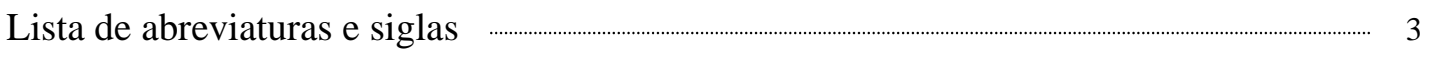

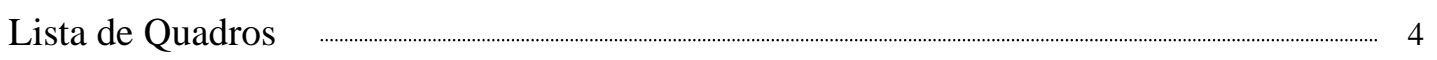

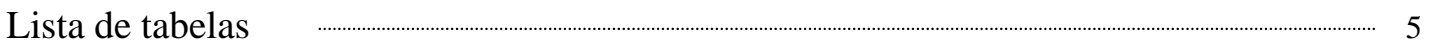

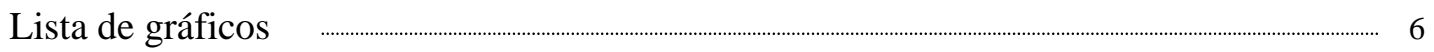

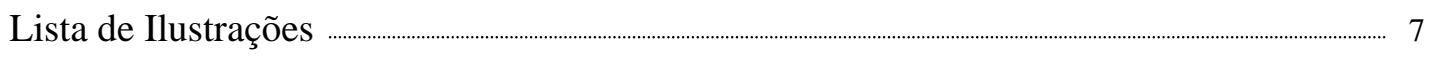

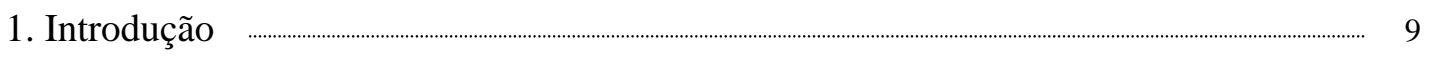

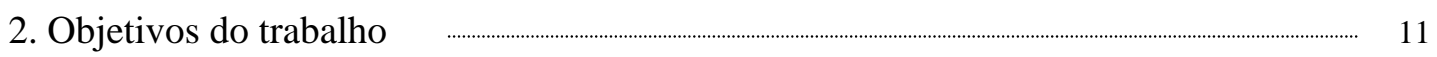

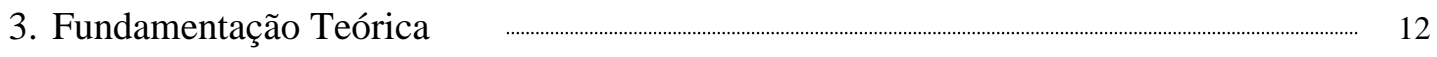

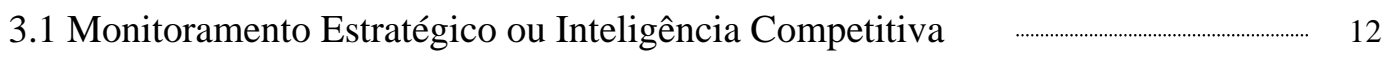

3.1.1 A necessidade da informação para uma organização $\quad$ _.......................................... 12

3.1.2 Como recuperar informação para a organização $\quad$ ………………………………............ 16

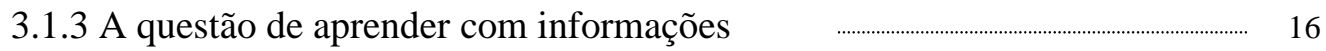

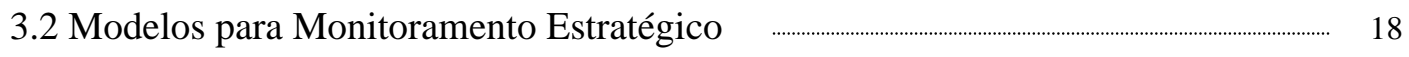

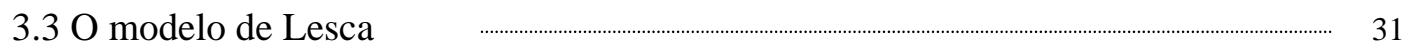

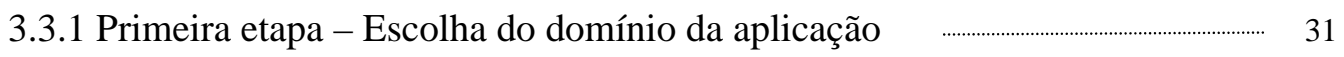

3.3.2 Segunda etapa - Amplitude do processo do MAE-IC $\quad$ _...………………………….... 31

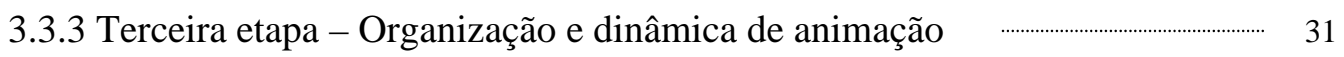

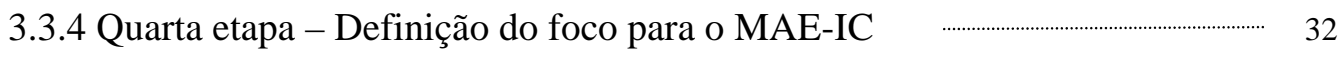

3.3.5 Quinta Etapa - Criação coletiva de sentido ..................................................................... 34

3.3.6 Sexta etapa - Organizar continuar o rastreamento das informações, do

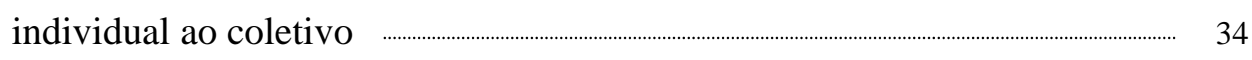

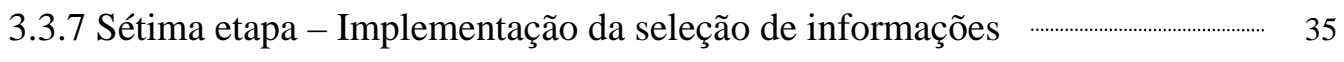

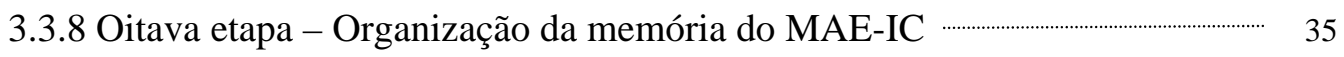


3.3.9 Nona Etapa - Difusão das informações e do conhecimento produzido ……... 36

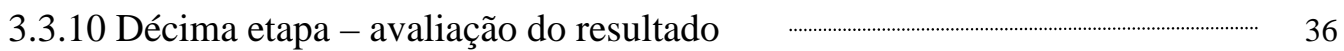

3.4 A Internet como fonte de informações para Monitoramento estratégice …………………..... $\quad 37$

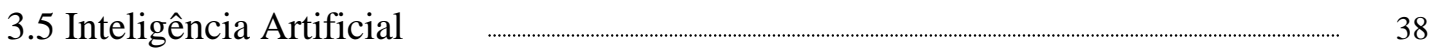

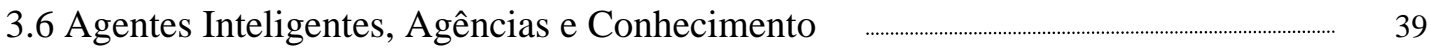

3.6.1 Agentes e a comparação com a mente humana por Marvin Minsky $\quad$ …….... $\quad 39$

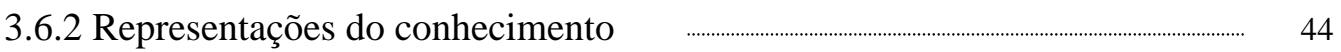

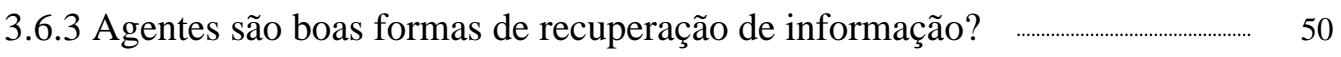

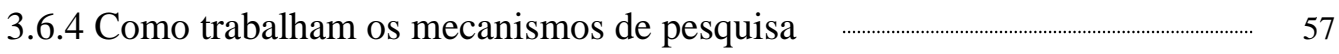

3.7 Um estudo de caso de Inteligência Competitiva utilizando Agentes Inteligentes, segundo Lafaye (2005)

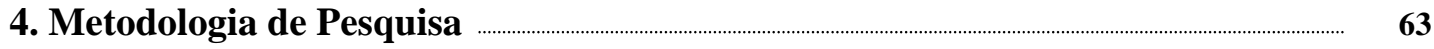

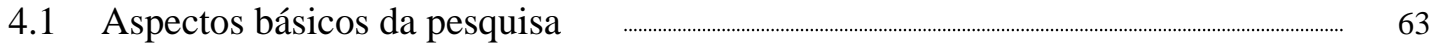

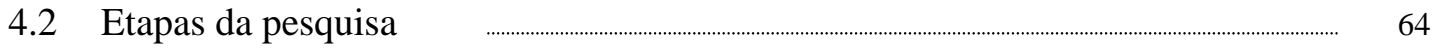

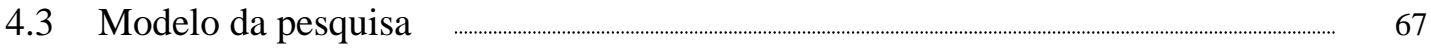

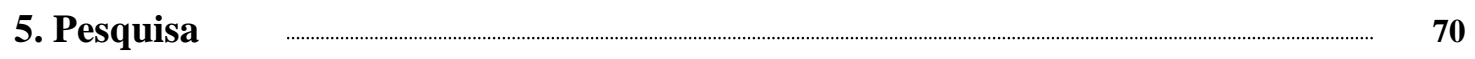

5.1 Desenvolvimento e aplicação de uma ferramenta de busca na Internet $\quad$ ………..... $\quad 70$

5.2 Estabelecimento do foco de monitoramento …uㅡ.

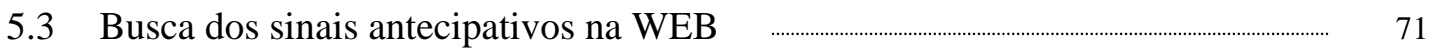

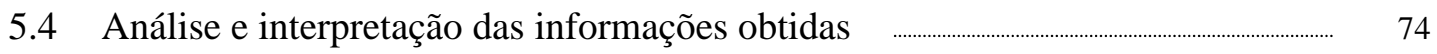

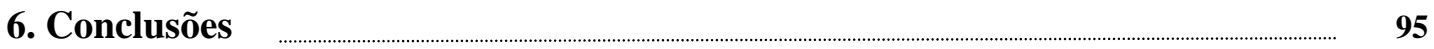

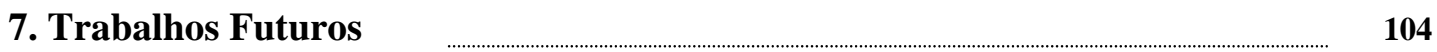

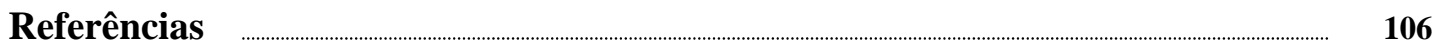

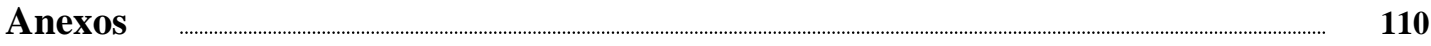

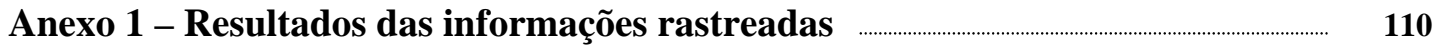




\section{LISTA DE ABREVIATURAS E SIGLAS}

URL - Universal Resource Locator

FTP - File Transfer Protocol

HTML - Hyper Text Markup Language

HTTP - Hyper Text Transfer Protocol

IC - Inteligência Competitiva

ME - Monitoramento Estratégico

MAE - Monitoramento Antecipativo Estratégico

AAII - Agente Artificial de Informação Internet

ABRAS - Associação Brasileira de Supermercados

APAS - Associação Paulista de Supermercados

PROVAR - Programa de Administração de Varejo 


\section{LISTA DE QUADROS}

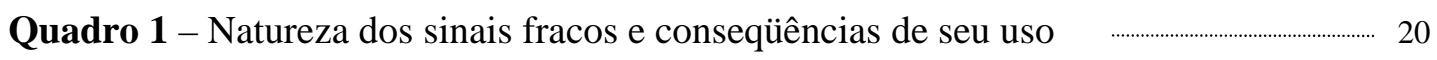

Quadro 2 - Componentes de análise do concorrente (adaptado de PORTER, 1980)…….. 25

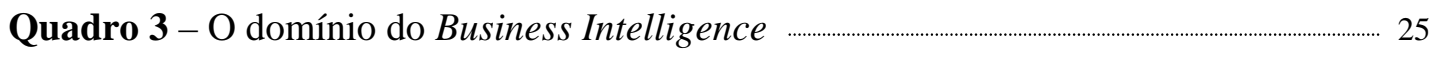

Quadro 4 - Modos de rastreamento e interpretação ……………………………………………………………….... 27

Quadro 5 - Algumas definições de IA ………… 


\section{LISTA DE TABELAS}

Tabela 1: Tabela com número de informações rastreadas e de interesse, por fonte ………..... 75

Tabela 2: Demonstrativo de informações rastreadas no site da Folha de São Paulo -.......... 76

Tabela 3: Demonstrativo de informações rastreadas no site do ValorOnLine …........................... 77

Tabela 4: Demonstrativo de informações rastreadas no site da ABRAS …………….............. 78

Tabela 5: Demonstrativo de informações rastreadas no site da APAS ………....................... 78

Tabela 6: Demonstrativo de informações rastreadas no site do Estado de São Paulo -……. 78

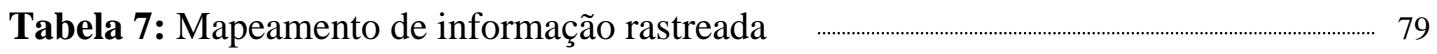




\section{LISTA DE GRÁFICOS}

Gráfico 1 - Matriz de diversas causas 


\section{LISTA DE ILUSTRAÇÕES}

Ilustração 1 - Esquema conceitual do comportamento de gestores frente à informação 12

Ilustração 2 - Esquema conceitual para rastreamento do ambiente ………………………............ 13

Ilustração 3 -O processo de Monitoramento estratégico ou Inteligência Competitiva 21

Ilustração 4 - Inteligência Coletiva Criativa - um modelo conceitual …………………………. 23

Ilustração 5 - Formas de captação de informação organizacional externa …………………… 24

Ilustração 6 - Estágios no gerenciamento da engenharia de pesquisa ………………............... 28

Ilustração 7 - Evolução de programa de IC (PRESCOTT \& MILLER, 2002) …………… 29

Ilustração 8 - Conceito de rastreamento e interpretação _..................................................................... 30

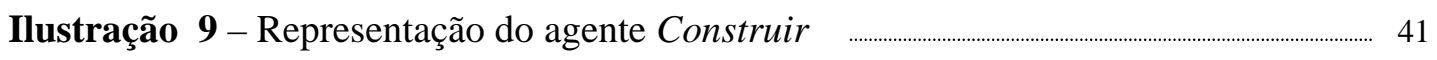

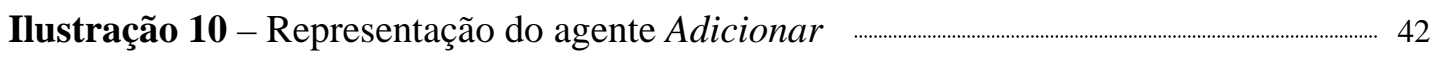

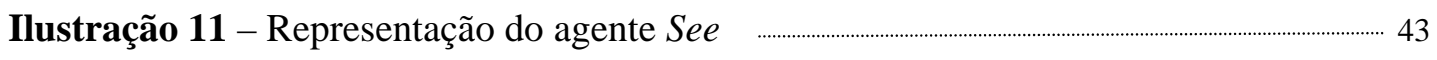

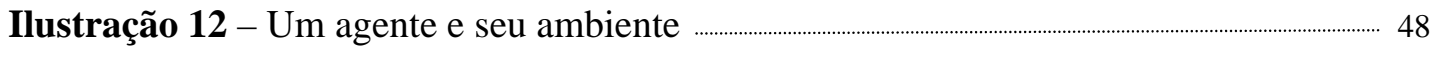

Ilustração 13 - Subsistemas de percepção e ação ………........................................................................... 48

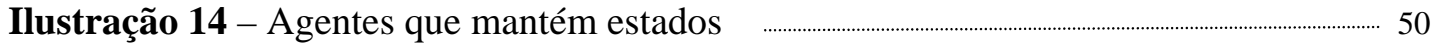

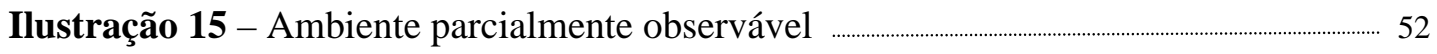

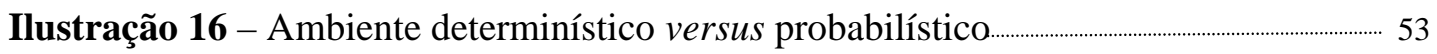

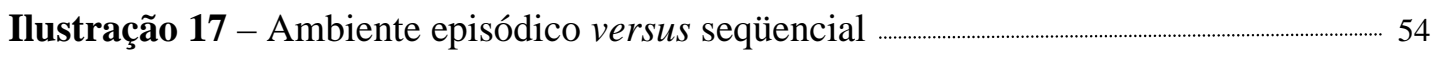

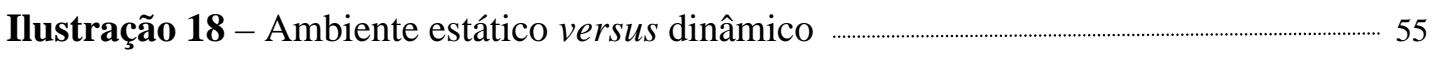

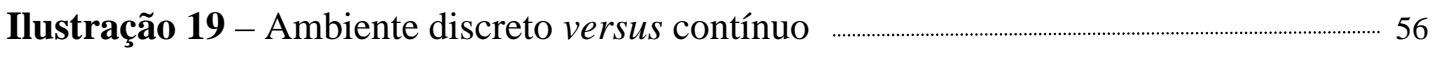

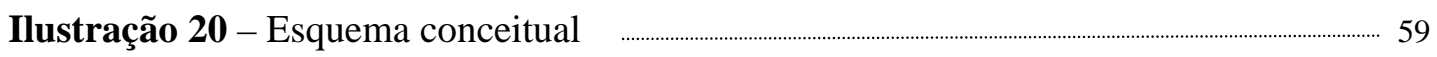

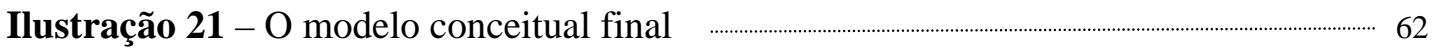

Ilustração 22 - Modelo para solução de monitoramento estratégico envolvendo abordagem do monitoramento, pesquisador e agente inteligente $\quad$...………. 64

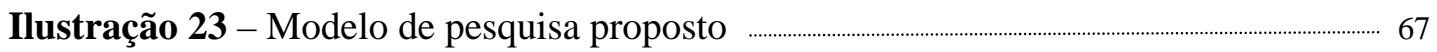

Ilustração 24 - Tela inicial do programa de indexação da Web ………………………………….... 72

Ilustração 25 - Tela após o início do programa de indexação da Web ……………………………….... 73

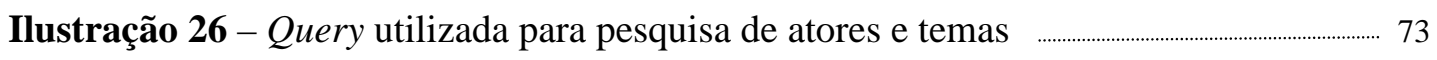

Ilustração 27 - Exemplo do resultado parcial do agente de busca _..._._........................................ 74

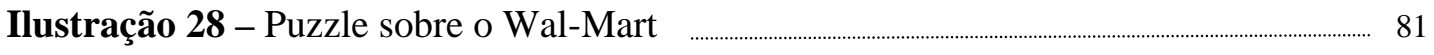

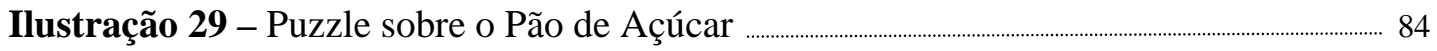

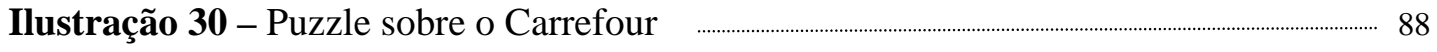

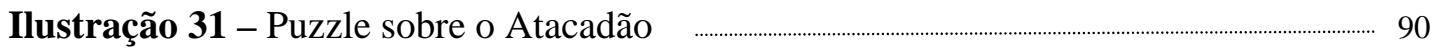


Ilustração 32 - Puzzle geral sobre o mercado supermercadista 


\section{INTRODUÇÃO}

Segundo Liu (1998), existe uma dependência crítica entre uma organização e seu ambiente externo, que requer dela um alerta constante para mudanças em seus relacionamentos externos e na forma como estes podem provocar efeitos em seus negócios. O rastreamento de informações do meio externo é vital para sua sobrevivência e desenvolvimento. $O$ autor ressalta alguns estudos que revelaram um relacionamento positivo entre rastreamento de informações e performance organizacional. Apesar de salientar a importância da recuperação e do tratamento de informações, ele descreve também as dificuldades em obtê-las. "Existe um grande crescimento de informações disponibilizadas por computadores, que podem ser uma ameaça, pois podem exceder a nossa capacidade de gerenciamento de rapidamente filtrar, ordenar, escolher e encontrar a informação correta" (LIU, 1998).

Essas informações, que são de extrema importância para a captação de sinais antecipativos para a organização, possuem como características serem qualitativas, fragmentadas, incompletas, incertas e imprecisas (LESCA, 2003), o que significa uma grande dificuldade para obtê-las e transformá-las em conhecimento coletivo para a organização.

Com a disseminação da Internet, a quantidade de fontes de textos e dados para obtenção desse tipo de informação cresceu de uma forma exponencial. Mohammadia et al (2004) afirmam que a World Wide Web tem adicionado uma abundância de dados e informações, aumentando muito a complexidade para seus disseminadores e usuários, e que com essa complexidade vem o problema de se localizar a informação útil e relevante, ou seja, a informação que satisfaça à necessidade dos gestores, que são as informações inclusas nos campos da Inteligência Competitiva, também denominada Monitoramento Estratégico (LESCA, 1997).

Segundo a metodologia de Lesca (2003) mais precisamente, a Inteligência Competitiva (IC) procura criar sentido a partir da detecção e da exploração de sinais de alerta precoce, também chamados sinais fracos, captados no ambiente. Este termo é proveniente do que Ansoff (1975) chama de "sinais fracos" (weak signals). Lesca (2003) denomina essa etapa de captação desses sinais de rastreamento. $\mathrm{O}$ rastreamento consiste, em um primeiro momento, em captar as informações do ambiente externo e, em um segundo momento, filtrar de forma inicial essas informações de maneira a serem transformadas, posteriormente, em informações úteis, após a etapa de formação de sentido. 
Uma questão natural é se um sistema baseado em computadores pode suportar o rastreamento e a interpretação estratégicos (SSI - Strategic Scanning and Interpretation) e como construir esse ambiente de software para contribuir no rastreamento de informações para gestores, e que façam sentido para estes. Sistemas de informações gerenciais ou sistemas gerenciais de suporte à decisão são exemplos de tentativas anteriores de se prover suporte efetivo para o nível decisório que não se mostraram suficientes para alcançar os objetivos gerenciais esperados (LIU, 1998).

Eles não são, em sua maioria, suficientemente flexíveis para captar mensagens e sinais, do mundo dos negócios, que indiquem oportunidades ou antecipem problemas ou rupturas.

Em nossas pesquisas nós exploraremos o uso de uma alternativa, o uso de agentes de software, como uma forma de rastrear e interpretar sistemas de suporte na tentativa de ultrapassar as barreiras descritas acima. (LIU, 1998)

Liu (1998) defende que uma solução viável, e que em sua opinião parece ser a melhor, é a de se utilizar agentes inteligentes, também denominados agentes de software. Agentes de software são programas computacionais ou entidades que agem para realizar tarefas especializadas em favor dos usuários. Eles parecem ter vários atrativos. Eles agem, com algum grau de autonomia, na direção de alcançar ou realizar certas especificações dos usuários ou metas geradas automaticamente.

Existem três formas principais de se construir agentes para a Internet:

a) O primeiro é integrar agentes com sistemas de busca existentes.

b) A segunda forma é baseada em regras. Um engenheiro do conhecimento levanta essas regras e incorpora-as no agente.

c) A terceira forma é uma abordagem de aprendizagem, onde o agente é treinado a aprender as preferências e ações de seu usuário (JANSEN, 2002 apud MOHAMMADIAN, 2004).

A construção de um protótipo de agente inteligente de software será baseada na primeira forma descrita por Mohammadian (2004) para a fase de Inteligência Competitiva que passaremos a utilizar e a denominar de rastreamento. 


\section{OBJETIVOS DO TRABALHO}

Este trabalho tem como objetivo explorar a Web como fonte principal de sinais antecipativos ou sinais de alerta precoce para organizações que desejam minimizar riscos em suas tomadas de decisão. O método para trabalhar sinais de alerta pressupõe vários passos, mas este trabalho tem como objetivo principal o rastreamento de informações, dado um foco definido, e a construção de puzzles (quebra-cabeças) como pré-análise das informações.

Essas informações e conclusões preliminares são analisadas em maior detalhe através de reuniões de formação de sentido posteriores, mas cujo desenvolvimento e análise não constam do escopo deste trabalho.

Como a Web é um mundo ainda pouco padronizado e com uma quantidade de informações brutal a serem disponibilizadas em uma pesquisa específica, o objetivo é também a proposta e construção de um protótipo, baseado no conceito de agentes inteligentes de software que facilite a fase de rastreamento inicial, dentro de um foco de maior precisão.

Após a coleta de informações através deste protótipo serão feitas as mesmas pesquisas utilizando o mecanismo de busca do produto de mercado hoje mais disseminado, o Google A finalidade desta comparação é a identificação de possíveis disparidades e a análise delas para alterações e melhorias do protótipo criado, avaliar e discutir a adequação dos sinais coletados por esse programa e se o conceito de agentes pode ou não ser utilizado de forma a recuperar informações para utilização em inteligência competitiva de forma mais efetiva.

Para coleta, objeto desta pesquisa, será definido um foco específico de busca, no caso supermercados no mercado brasileiro, mais precisamente Pão de Açúcar, Carrefour e WalMart, com o tema de aquisições, fusões, compra e venda de bandeiras, através das fontes com acesso via Web de atuação generalista como Valor Econômico, Folha de São Paulo, O Estado de São Paulo e fontes especializadas como a ABRASNET da ABRAS (Associação Brasileira de Supermercados), a APAS (Associação Paulista de Supermercados) e PROVAR (Programa de Administração de Varejo). 


\section{FUNDAMENTAÇÃO TEÓRICA}

\subsection{Monitoramento Estratégico ou Inteligência Competitiva}

\subsubsection{A necessidade da informação para uma organização}

Um dos maiores desafios de uma organização inteligente (que aprende, é apta para criar e reunir conhecimento e modificar seu comportamento para refletir o novo conhecimento) é entender como o ambiente externo está mudando, quais os significados dessas mudanças e como melhor responder às novas condições. O processo de aprender sobre o ambiente externo é denominado "rastreamento do ambiente" — a arte de reunir e interpretar informação sobre o ambiente de forma a permitir que a organização tenha conhecimento para desenvolver cursos efetivos de ação (CHOO, 2002).

Para Choo (2002), a forma histórica como os gerentes trabalhavam a informação era composta inicialmente por três conjuntos de atividades: busca de informação, uso da informação e necessidades de informação. A busca de informação e sua utilização eram guiadas pela necessidade, e, alimentando o ciclo, acabavam gerando mais necessidades de informação. Outros aspectos também influenciavam, segundo o autor, a forma como os gerentes captavam informações - dimensões situacionais, estratégias organizacionais e traços gerenciais, representados na Ilustração 1:

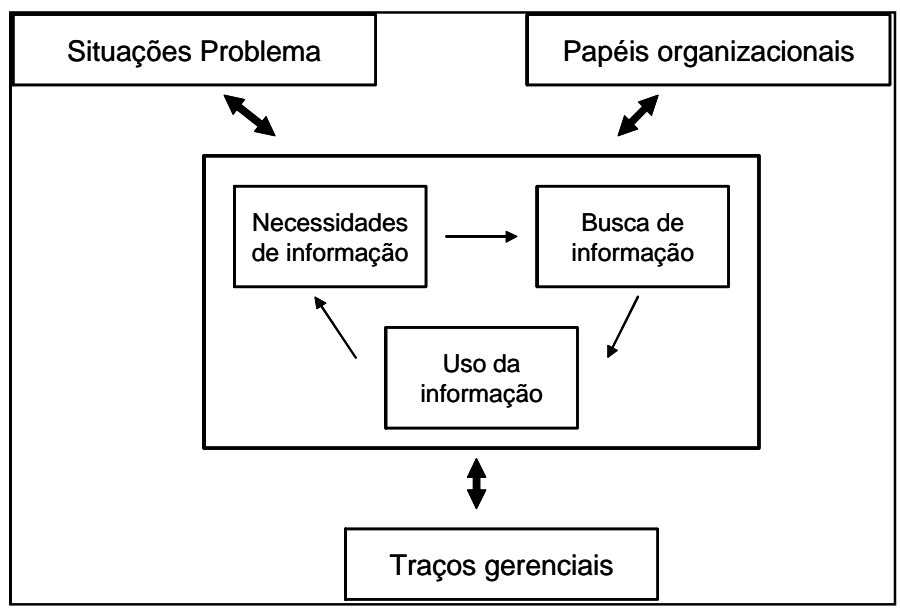

Ilustração 1 - Esquema conceitual para o comportamento de gestores diante da informação.

Fonte: Choo (2002, p. 65).

a) Situações-problema: referem-se às dimensões dos ambientes internos e externos, assim 
como a normas organizacionais e incertezas externas que determinam o uso da informação (MACMULLIN \& TAYLOR, 1984 apud CHOO, 2002).

b) Papéis organizacionais: são formas de agrupar atividades gerenciais em largas categorias ou papéis funcionais (MINTTZBERG, 1973).

c) Traços gerenciais: referem-se a tipo de características pessoais, como especialização ou seus estilos cognitivos.

Estudos posteriores, que investigam os efeitos externos às organizações, alteram os significados e denominações da figura anterior, passando a ser como representados na Ilustração 2:

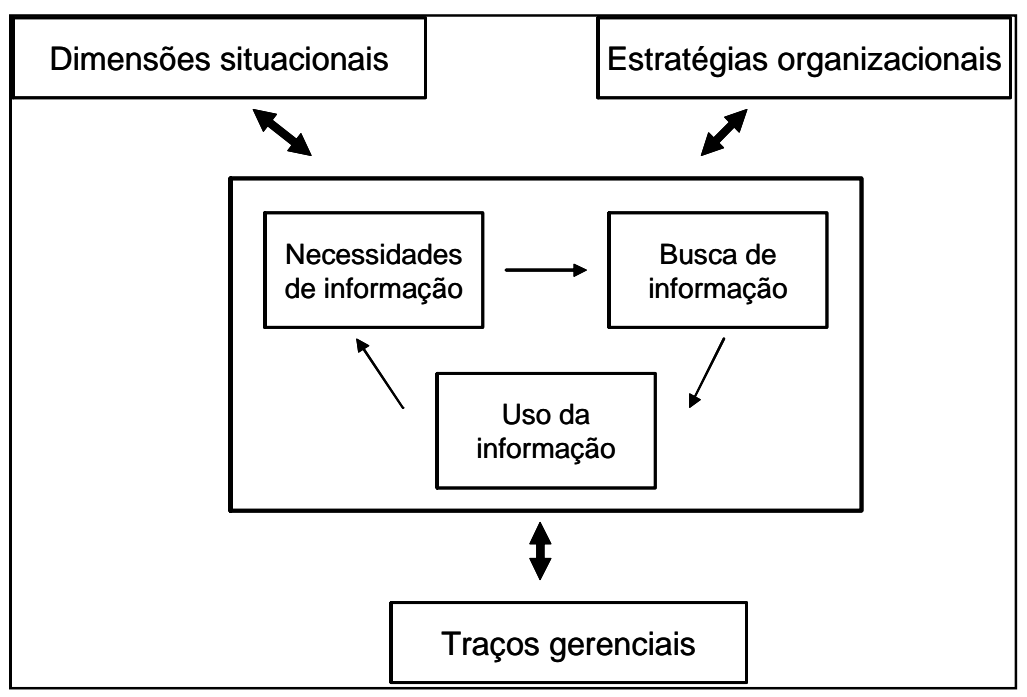

\section{Ilustração 2 - Esquema conceitual para rastreamento do ambiente.}

Fonte: Choo (2002, p. 98).

a) Dimensões situacionais: freqüentemente medidas pela incerteza do ambiente externo, um conceito que é muito relacionado com a percepção da análise do ambiente como rastreamento-interpretação-aprendizagem.

b) Estratégias organizacionais: referem-se à posição ou instância em que a empresa se encontra versus o ambiente externo, e dois exemplos de tipologias estratégias bem conhecidas foram desenvolvidas por Miles \& Snow (1978 apud CHOO, 2002) e Porter (1980 apud CHOO, 2002).

c) Traços gerenciais: incluem especialidades funcionais da gerência, níveis hierárquicos e estilos cognitivos. 
As informações e sua necessidade nas organizações que se pretendem competitivas são bem descritas nas palavras de Liam Fahey:

[...] ajudar as organizações a vencerem, descobrirem as táticas e superarem concorrentes atuais e potenciais e olharem para a concorrência como forma de auto-análise para verificar até que ponto as próprias organizações funcionam bem. (FAHEY apud PRESCOTT \& MILLER, 2002)

Prescott \& Miller (2002) descrevem como desafios ao isolamento empresarial a necessidade de identificação das fontes de informação, a coleta de dados e a análise das informações, com a aplicação de ferramentas afiadas e de técnicas como jogos de guerra, análise de cenários competitivos, mineração de dados (data mining) nas informações já arquivadas (de modo que possam ser aplicadas a tarefas analíticas), reconhecimento de tecnologias por meio do acompanhamento de patentes e outras ferramentas que revelem, por exemplo, áreas nas quais a concorrência está perto de fazer avanços importantes.

Para os autores, é fundamental o acompanhamento das intenções dos concorrentes e de concorrências imprevistas no mercado por meio de exame de registros públicos, monitoramento atento na Internet e nos meios de comunicação de massa, contato com clientes, fornecedores, parceiros, especialistas do setor e outras fontes confiáveis, criação de perfis psicológicos de tomadores de decisão de alto nível, com o objetivo de reunir dados relativos ao que os concorrentes estão fazendo e por fazer, e incorporar esse conhecimento ao planejamento dos negócios.

Muitas vezes, a falta de habilidade de gerentes em enxergar antecipadamente mudanças que podem destruir as vantagens competitivas de uma organização, tem sido apontada como uma das principais ameaças para sustentar o sucesso em mercados que possuem ambientes de negócios de rápida evolução (ILMOLA et al, 2002 apud DECKER et al, 2005). Essas dificuldades de antecipação provêm das naturezas descontínuas da ocorrência de fatos decisivos, no fato desses gerentes considerarem os procedimentos de monitoramento contínuo do ambiente complexos e dispendiosos, na grande quantidade de informação que hoje está disponível através da Internet, fazendo com que, freqüentemente, estes mesmos gerentes se restrinjam a processos de recuperação de informações para ocasiões excepcionais, como reuniões estratégicas.

[...] nós temos aprendido de pesquisas anteriores que a inércia cognitiva de gerentes em responder a iminentes mudanças do ambiente aumentam a probabilidade de erros em planejamento de mercado (REGER \& PALMER, 1996; HODGKINSON, 1997; DANIELS et al, 2002 apud DECKER et al, 2005.). 
Iniciando com o trabalho pioneiro de Ansoff (1975), a literatura referente ao gerenciamento estratégico de mercado tem sugerido que esses problemas podem ser reduzidos por iniciativas proativas baseadas em sinais fracos, que são alertas internos e externos em termos de eventos e desenvolvimentos que ainda estão incompletos para permitir uma estimativa precisa de seus impactos. Este ponto levanta duas questões que necessitam de respostas práticas. A primeira acerca do tipo de ações que devem ser tomadas se o impacto de um fato for ainda desconhecido; a segunda, de como detectar sinais fracos, em particular quando associados a mudanças e descontinuidades causadas por fatores estranhos à indústria.

A primeira pergunta, segundo Decker et al (2005), só pode ter uma resposta quando se está com o fato em mãos, quanto a se ter ou não conhecimento quanto à probabilidade de ocorrência e credibilidade das fontes. Quanto a como detectar sinais fracos quando associados por fatores que a própria organização e seus gestores desconhecem, essa é a motivação da Inteligência Competitiva.

No contexto dos negócios, uma nova tendência ou uma mudança estrutural surpreendente é raramente criada por um simples item de informação de um só emissor. Para o autor, os sinais fracos emergem de uma combinação de mensagens, relatórios, discussões e mesmo especulações da parte de pessoas que conhecem o assunto. A combinação desses materiais contendo informações fragmentadas é o maior desafio para a detecção de sinais fracos, e tem que ser feita antes que se torne evidente para toda a indústria. Conseqüentemente, a detecção desses sinais antecipativos oferece uma vantagem competitiva essencial (DECKER et al, 2005).

Uma pergunta freqüente que nos fazemos em IC é sobre a diferença entre um sinal forte e um sinal fraco antecipativo. Os autores respondem:

Sinais fortes diferem de sinais fracos pela sua alta credibilidade comparativamente um a outro e também porque requerem ação gerencial imediata. Hiltunen (2001) enfatiza a tendência inexistente ou a falta de passado facilmente reconhecível de sinais fracos. Com essa falta de história é difícil o reconhecimento de desenvolvimentos emergentes. Mesmo a definição de critério para acesso a mudanças indicadas pelos sinais fracos antecipativos parecem ser impossíveis até que eles se transformem em sinais fortes. (DECKER et al 2005)

As características relevantes das fontes das quais são retirados os sinais fracos antecipativos são muito similares ao conteúdo e à estrutura da Web. No domínio da IC, a análise e a interpretação de pedaços de informação múltiplos e aparentemente não correlacionados é que definem a qualidade da Inteligência Competitiva. 


\subsubsection{Como recuperar informação para a organização}

Os termos Inteligência Competitiva (IC), Monitoramento Estratégico (ME) ou Monitoramento do Ambiente (MA) referem-se ao que a alta gerência da organização estuda e monitora em ambientes relevantes para os seus negócios. Contrastando com a pesquisa de mercado, que usualmente inicia com objetivos bem definidos a serem atingidos, a IC inspeciona o ambiente de negócios à maneira de um radar, continuamente (DECKER, 2005).

Prescott \& Miller (2002) iniciam seu livro já esclarecendo a diferença do trabalho de espionagem nas empresas:

\footnotetext{
Distantes das sombras dos estereótipos "spy versus spy" corporativos, nos dias de hoje, os profissionais de IC coletam, analisam e aplicam, legal e eticamente, informações relativas às capacidades, vulnerabilidades e intenções de seus concorrentes e monitoram acontecimentos do ambiente competitivo geral (como concorrentes antes desconhecidos que surgem no horizonte ou novas tecnologias que podem alterar tudo). (PRESCOTT \& MILLER, 2002)
}

Algumas empresas, com o objetivo de aumentar sua eficácia, prepararam a organização para conviver com as cada vez mais intensas mudanças no ambiente externo; outras buscaram identificar as mudanças desse ambiente externo para planejar o tipo de intervenção no ambiente interno. Como ponto comum, existe a certeza da necessidade de interação entre a empresa e seu meio externo, influenciando e sendo influenciada por ele, que se encontra em processo de transformação permanente e acelerado (ROEDEL, 2005).

Para Roedel (2005), nessa situação, a necessidade de introduzir os conceitos de inteligência competitiva (compreendendo coleta, tratamento, análise e disseminação de atividades dos concorrentes, fornecedores, clientes, tecnologias e tendências gerais dos negócios) é de fundamental importância. Monitorar continuamente o ambiente externo permite estabelecer um direcionamento estratégico e tomar decisões em tempo real. Formular estratégias em tempo real tem sido um fator identificado como uma opção ágil e dinâmica de responder prontamente às mudanças nas demandas e no ambiente de negócios das empresas.

\subsubsection{A questão de aprender com informações}

Questionando a administração estratégica, Mintzberg, citado por Roedel (2005), apresenta a escola do aprendizado como a que tem assumido grande relevância nos últimos anos. Dentre as premissas citadas por Mintzberg, destacam-se:

a) A natureza complexa e imprevisível da organização. 
b) O processo de formação da estratégia depende de um processo de aprendizado contínuo ao longo do tempo e, no limite, acaba tornando a formulação e a implementação do aprendizado indistinguíveis.

c) Embora o líder possa até ser o principal aprendiz, em geral é o sistema coletivo que aprende.

d) Esse aprendizado acontece de forma emergente, por meio do comportamento e do estímulo ao pensamento retrospectivo que leve a compreender a ação a ser tomada.

e) A liderança deixa de ter o papel de preconceber estratégias deliberadas, mas de gerenciar o processo de aprendizado estratégico.

Nonaka \& Takeuchi, citados por Roedel (2005), propõem uma taxonomia para o conhecimento, classificando-o em explícito (formal e sistêmico), expresso em palavras e números e tácito (algo pessoal e enraizado nos indivíduos, dotado de emoções, valores, ideais e de aspectos cognitivos). Dessa forma, o grande desafio das organizações é compartilhar conhecimentos, transformando em explícito o conhecimento tácito para levar à criação do conhecimento organizacional. Esses aspectos têm como objetivo assegurar que, ao criar conhecimento, sua gestão o torne disponível para toda a empresa.

Para Lesca (2003), no Monitoramento Antecipativo Estratégico - Inteligência Competitiva (MAE-IC), a fase Criação Coletiva de Sentido consiste em captar e transformar a memória da organização como representação durável, explícita, despersonalizada de seus conhecimentos e das informações, que facilite o acesso, o compartilhamento e a reutilização, pelos profissionais, das informações captadas externamente. A palavra "memória" é utilizada pelo autor para designar todos os lugares onde possa estar uma informação ou um conhecimento.

É da maior importância o cruzamento das informações com os conhecimentos tácitos e as experiências de vários membros da organização, se possível complementares em termos de conhecimento (LESCA, 2003).

Para Decker (2005), a combinação do material captado contendo informações fragmentadas é o maior desafio para a detecção de sinais fracos e tem que ser feita antes que a complementação dos fragmentos se torne evidente para a grande massa de especialistas externos em toda a indústria.

O conhecimento precisa, afinal, ser gerado e analisado antes de poder ser comunicado e 
administrado. Isso se aplica tanto aos dados gerados internamente quanto à inteligência obtida de fontes situadas fora do âmbito da empresa, para que a confiabilidade e a credibilidade das informações sejam mantidas (PRESCOTT \& MILLER, 2002).

Esse é um papel que precisa ser coordenado de forma estreita entre a Gestão do Conhecimento e a Inteligência Competitiva.

\subsection{Modelos para Monitoramento estratégico}

O objetivo da busca proativa das informações, sua interpretação e utilização consistem em vigiar e antecipar a evolução do ambiente atual e potencial (clientes, concorrentes, fornecedores, poderes públicos etc.) de uma empresa. Monitoramento Estratégico é um tipo de expressão genérica, que engloba vários tipos de monitoramentos específicos, tais como o monitoramento tecnológico, o monitoramento de clientes (atuais e potenciais), o monitoramento de concorrentes (atuais e potenciais), o monitoramento de parcerias etc. (BLANCO et al, 2003).

Para Lesca (2003), mais precisamente, o monitoramento estratégico procura criar sentido a partir da detecção e da exploração dos sinais fracos — também chamados de sinais de alerta precoces - captados no ambiente externo. A expressão "sinais de alerta precoces" é proveniente do que Ansoff (1975 apud LESCA, 2003) chama de "sinais fracos" (weak signals). Segundo Lesca (2003), o objetivo do monitoramento estratégico, ou inteligência competitiva, consiste em criar oportunidades de negócios e reduzir os riscos e a incerteza, a fim de que a empresa possa agir rapidamente, no momento certo e de maneira apropriada à situação. Esta operação de detecção é qualificada de rastreamento.

Ainda segundo o autor, o rastreamento consiste, em um primeiro momento, em captar as informações e, em um segundo momento, em repassar essas informações de maneira eficaz. Essa tarefa de "repasse" implica fazer chegar essas informações de monitoramento estratégico à pessoa encarregada de armazená-las (por exemplo, o facilitador do monitoramento estratégico).

Em Mohammadian et al (2004), os mecanismos de busca e recuperação de informação têm aumentado de maneira significativa sua capacidade, mas Jansen (2002 apud MOHAMMADIAN, 2004) afirma que, embora esses mecanismos tenham se tornado bastante sofisticados, eles não podem e não provêem assistência suficiente para os usuários na ação de 
localizar e filtrar a informação relevante desejada por ele.

É preciso fazer com que a pesquisa possa conter formas de melhorar seus mecanismos para considerar necessidades particulares via seus métodos de filtragem. Para que este objetivo seja possível, é necessária uma concentração de tecnologias, que possam entender necessidades reais, claras e acessíveis, com capacidade de pesquisar, analisar e filtrar resultados a serem utilizados por gestores de informação. (JANSEN, 2002 apud MOHAMMADIAN, 2004)

Independentemente da questão tecnológica, as definições da tarefa de rastreamento das informações são numerosas. Segundo o autor, o rastreamento é uma operação contínua no tempo que enfatiza a pesquisa ativa de informações em caráter antecipativo. Ela é garantida por pessoas que têm a missão de antecipar as informações de monitoramento estratégico (MOHAMMADIAN, 2004).

A operação "de rastreamento e repasse" é realizada pelos colaboradores da empresa, os rastreadores, que compõem uma interface fundamental entre a empresa e seu ambiente, já que da sua vontade "de rastreamento" depende o sucesso da implantação do dispositivo de monitoramento estratégico e também a sua perenidade (BLANCO et al, 2003). Mais especificamente, essas informações estratégicas se referem a eventos, tendências e relacionamentos no ambiente de negócios, interno e externo, ao conhecimento que servirá de assistência para executivos de alto padrão identificarem e entenderem oportunidades e ameaças. O rastreamento de informações está olhando por informação (visão geral) e olhando para a informação (pesquisando) (AGUILAR, 1967 apud LIU, 1998).

Para Lafaye (2005), o rastreador é um ator no processo de monitoramento estratégico, e toda ou parte da sua missão na organização será identificar, acessar, selecionar e garantir as informações antecipativas externas diretas (coletadas por canais externos de monitoramento estratégico) e potencialmente agregar as informações antecipativas externas indiretas (obtidas do ambiente externo, trazidas à organização por captadores que não pertencem à equipe de monitoramento) a fim de alimentar o processo de monitoramento, seja ele interno ou externo.

Coloca-se então a questão da proveniência desses sinais de alerta precoce. A fim de conseguir captar esses sinais, certas empresas, consideradas de competitividade durável, implantaram um dispositivo que constitui o suporte do monitoramento estratégico (LESCA \& CASTAGNOS, 2000).

Normalmente, segundo Lesca (2003), são informações que possuem as seguintes características: são qualitativas, fragmentadas, incompletas, incertas e imprecisas. 
Podemos distinguir vários tipos de sinais antecipativos ou de fraca intensidade, bem como a conseqüência do seu uso (BLANCO et al, 2003). Os sinais de alerta precoce provenientes do que Ansoff (1975) chama de "sinais fracos" (weak signals), suas naturezas e as possíveis conseqüências de sua utilização.

\section{Quadro 1 - Natureza dos sinais fracos e conseqüências de seu uso}

\begin{tabular}{|l|l|}
\hline \multicolumn{1}{|c|}{$\begin{array}{c}\text { Natureza dos sinais de } \\
\text { alerta precoce }\end{array}$} & \multicolumn{1}{|c|}{ Conseqüência de suas análises } \\
\hline Antecipativa & $\begin{array}{l}\text { Como estão relacionados com eventos futuros potenciais, } \\
\text { podem fazer com que os gestores considerem cedo demais } \\
\text { para agir. }\end{array}$ \\
\hline Qualitativa & $\begin{array}{l}\text { Não são registros com dados ou passíveis de se fazer } \\
\text { inferências sobre eles. Sinais que alertam para o futuro, na } \\
\text { forma como são captados na Inteligência Competitiva, } \\
\text { não podem ser quantitativos ou factuais. }\end{array}$ \\
\hline Ambígua & $\begin{array}{l}\text { Não constituem certezas, mas dicas e caminhos incertos. } \\
\text { Eles podem ser interpretados de formas diferentes, sem } \\
\text { possibilidade de ter "a" interpretação correta. }\end{array}$ \\
\hline Fragmentada & $\begin{array}{l}\text { São fortemente fragmentados e devem ser pacientemente } \\
\text { coletados e agrupados por vários rastreadores de } \\
\text { ambiente. Vistos separadamente, são suspeitos; somente } \\
\text { possuem significado quando checados uns com os outros. }\end{array}$ \\
\hline De várias representações & $\begin{array}{l}\text { Pedaços de informação podem ser coletados em qualquer } \\
\text { formato, assim como: alguém ouvir uma conversa não } \\
\text { intencional, dados eletrônicos, mensagens de conferências } \\
\text { etc. Já que não são homogêneos, sua exploração é a de } \\
\text { maior dificuldade. }\end{array}$ \\
\hline
\end{tabular}

Fonte: Blanco (2003, p. 82).

A operação de "rastreamento" e "repasse" das informações insere-se no cerne do dispositivo mais global do MAE (Monitoramento Antecipativo Estratégico) com, além dos problemas acima apontados, os que são citados a seguir: 
Convém, no entanto, observar que, assim como os diferentes trabalhos de pesquisa de nossa equipe e os diversos trabalhos acadêmicos, nossas intervenções em empresas fizeram emergir uma problemática crucial com relação à perenidade do dispositivo de monitoramento estratégico e aos fatores críticos de sucesso de que ela depende. Constatamos que, em certos casos, a implantação de um dispositivo como esse podia acabar ao final de alguns meses. Uma das causas seria a falta de motivação dos rastreadores para a execução da tarefa 'de rastreamento e de repasse' das informações MAE. (BLANCO et al, 2003, p. 82)

Ainda por Blanco et al (2003), a Inteligência Competitiva é um processo de captação de informação representado pelo modelo da Ilustração 3, que pode ser visto conjuntamente com outro processo, o de aprendizagem constante da organização:

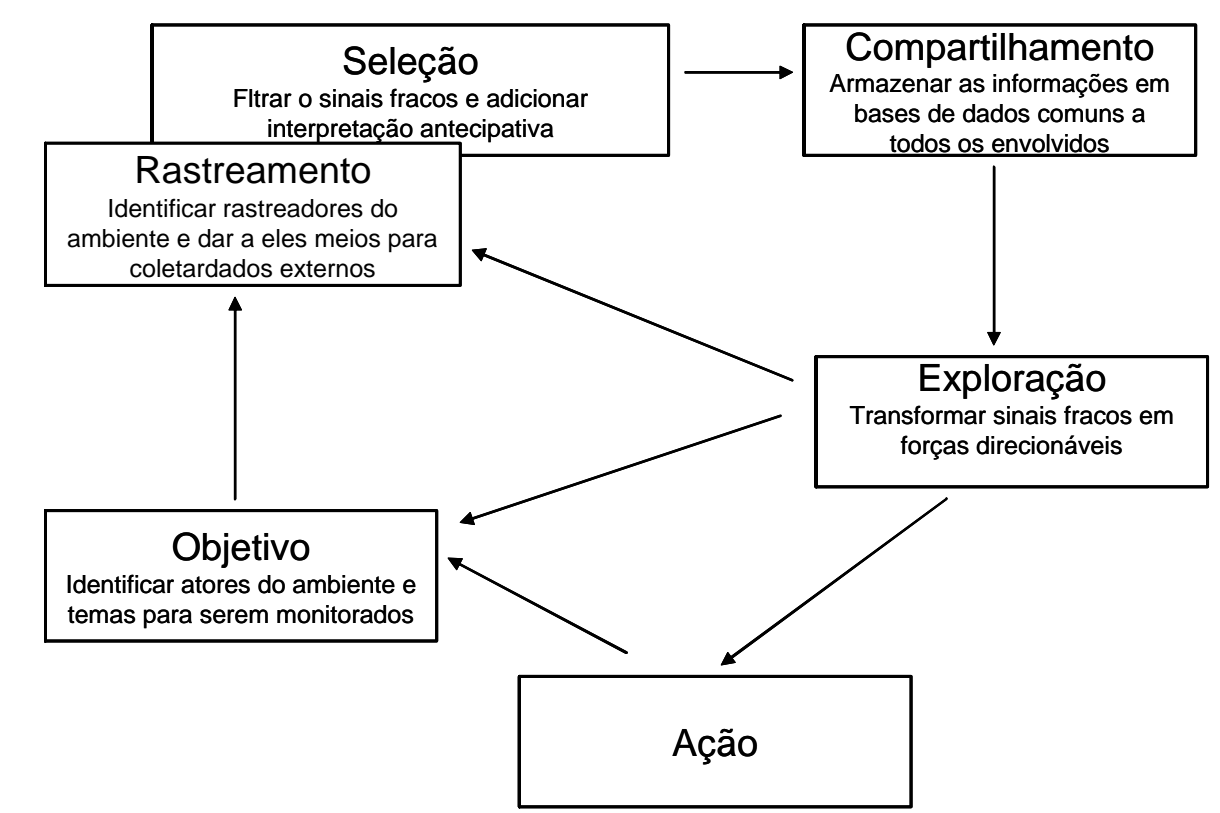

Ilustração 3 - O processo de Monitoramento Estratégico ou Inteligência Competitiva.

Fonte: Blanco (2003, p. 81).

Segundo Blanco et al (2003), provavelmente devido aos sinais fracos que estão sendo captados não terem uso imediato ou significado óbvio, alguns gerentes consideram sua exploração muito difícil. Apesar deste fato os autores perceberam que, mesmo com dificuldades, esses gestores não gostariam de abdicar do que a Inteligência Competitiva pode proporcionar.

Talvez eles preferissem receber sinais fracos de forma apropriada somente quando necessário. No entanto, já que métodos como esses não estão disponíveis esses gerentes preferem abdicar de explorar esses sinais. No entanto, se nossas hipóteses estão corretas, deverá haver aceitação por vários gerentes de um método para analisar pedaços de informação e produzir significado, ambos individualmente e coletivamente, mesmo quando não existe urgência para resolver um problema ou tomar uma decisão. (BLANCO et al, 2003)

Após a captação de informação, vem a fase de maior ou igual dificuldade, uma forma para 
produzir inteligência coletiva dos sinais fracos em todos os participantes do processo e futuramente de toda a organização. Reagrupar informações depende muito do estilo cognitivo, ou forma de assimilação, dos gerentes da organização. Esses estilos cognitivos há anos vêm sendo estudados por vários autores (MILLER, 1956; MINTZBERG, 1976; GOLDHAR, BRAGAW \& SCHWARS, 1976; TAGGARTT \& ROBEY, 1981 apud BLANCO et al, 2003). Alguns são os critérios de reagrupar informações (como critérios de similaridade, critérios de proximidade) e de criar ligações entre pedaços de informação (ligação por causalidade e ligações por influência).

Não faz parte do escopo deste trabalho aprofundar o estudo das formas de agrupamento de informações, etapa pós-rastreamento e filtragem das informações rastreadas.

Blanco et al.(2003) propõem um método simples para análise inicial dessas informações coletadas. Após o rastreamento das informações estas são verificadas individualmente e checadas para a identificação de sinais antecipativos.

Podemos agora resumir nosso conhecimento e incorporá-lo em um método macro para criar inteligência coletiva no ambiente de uma organização. A Ilustração 4, a seguir, é uma representação deste método (BLANCO et al., 2003): 


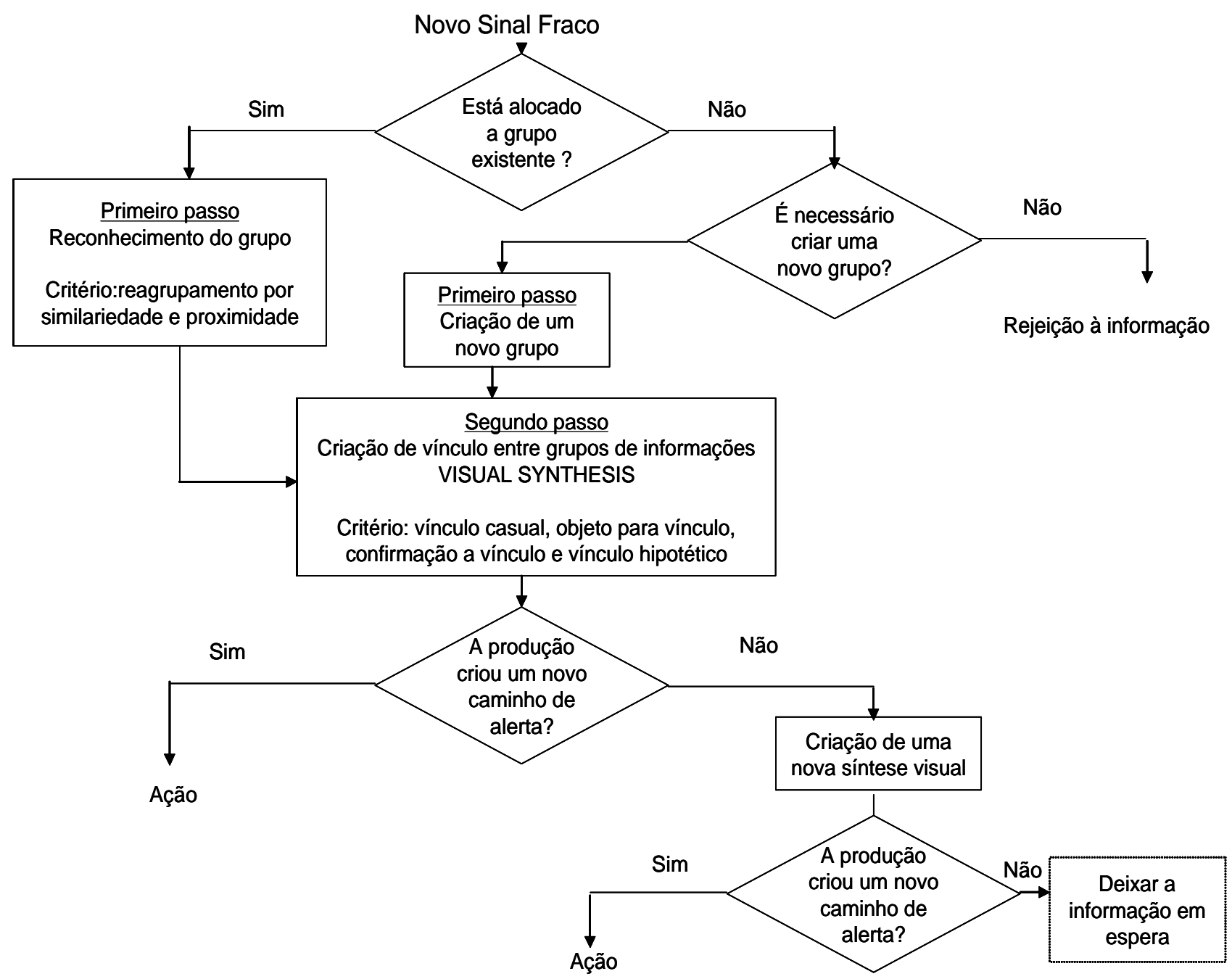

Ilustração 4 - Inteligência Coletiva Criativa - um modelo conceitual.

Fonte: Blanco et al (2003, p. 85). 
Diferentemente de Blanco, Choo (2002) considera Rastreamento do Ambiente e Inteligência Competitiva assuntos de magnitudes e significados diferentes. Demonstrado na Ilustração 5, o seu modelo de tratamento de informação, correspondente à versão contemporânea de seus modelos anteriores, defende várias formas de buscar informações nas organizações, evidenciando a força com que as organizações foram adotando o tipo de forma dessa busca em termos de tempo e profundidade.

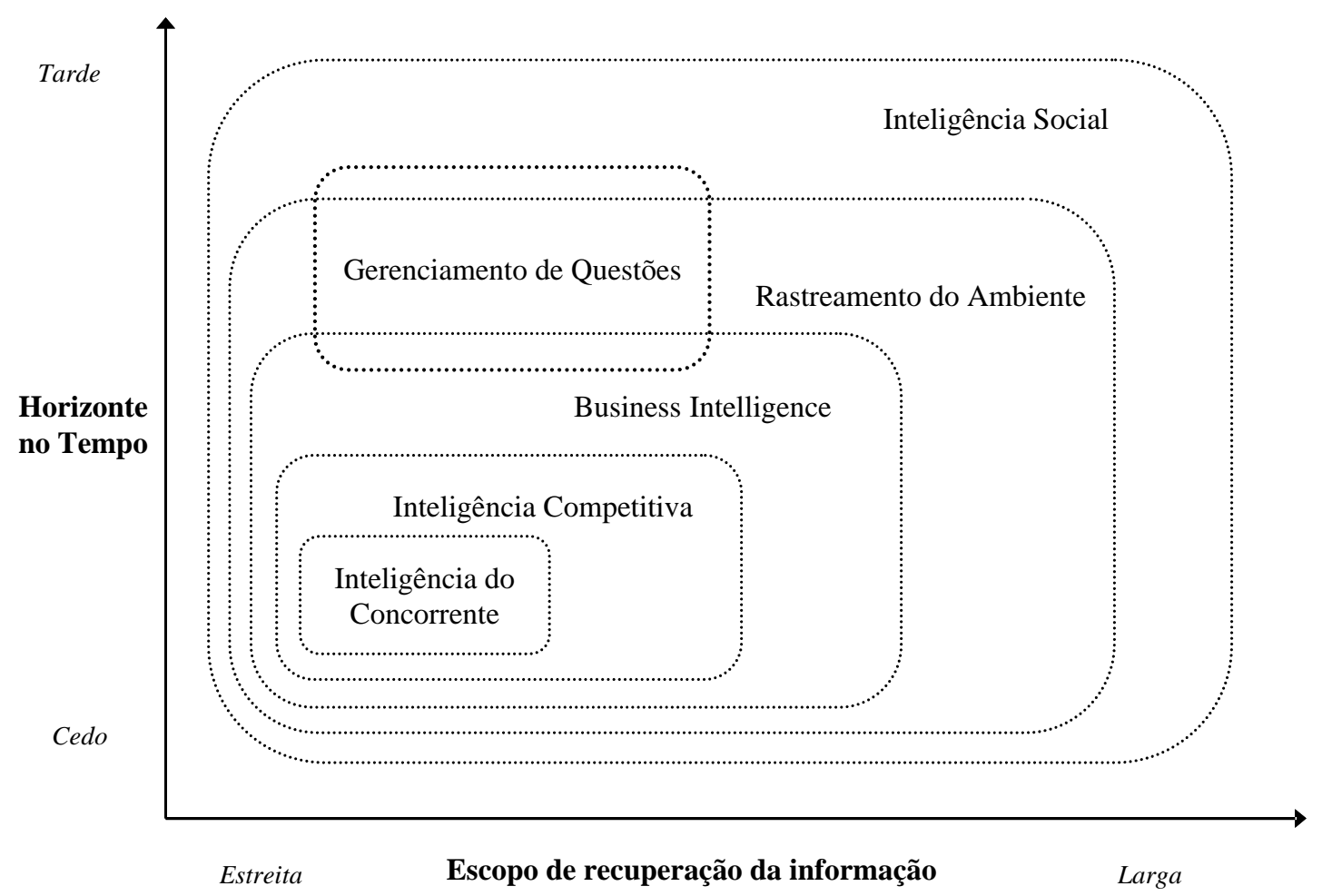

Ilustração 5 - Formas de captação de informação organizacional externa. Fonte: Choo (2002, p. 88).

a) Inteligência do concorrente (competitor intelligence): tem uma orientação para um período de tempo mais imediato, com questões mais táticas, com preocupações mais fundamentadas em preço, distribuição, promoção e outros. 


\section{Quadro 2 - Componentes de análise do concorrente (adaptado de PORTER, 1980)}

\begin{tabular}{|l|l|l|}
\hline \multirow{2}{*}{$\begin{array}{l}\text { 1. O que direciona o } \\
\text { concorrente? }\end{array}$} & $\begin{array}{l}\text { Metas } \\
\text { futuras }\end{array}$ & $\begin{array}{l}\text { Objetivos em todos os níveis de gerenciamento e } \\
\text { analisados em múltiplas dimensões }\end{array}$ \\
\cline { 2 - 3 } & Premissas & Premissas assumidas sobre eles mesmos e a indústria \\
\hline $\begin{array}{l}\text { 2. O que o } \\
\text { foncorrente está } \\
\text { fazendo e pode }\end{array}$ & $\begin{array}{l}\text { Estratégia } \\
\text { corrente }\end{array}$ & Como o concorrente está "concorrendo" atualmente \\
\cline { 2 - 3 } $\begin{array}{l}\text { 3. Perfil de respostas } \\
\text { do concorrente? }\end{array}$ & Capacidades & Forças e fraquezas do concorrente \\
\hline & $\begin{array}{l}\text { O concorrente está satisfeito com a sua posição atual? } \\
\text { Quais são as prováveis alterações de estratégias ou } \\
\text { mudanças que o concorrente fará? } \\
\text { Onde o concorrente é vulnerável? } \\
\text { O que provocará a maior e mais efetiva retaliação por } \\
\text { parte do concorrente? }\end{array}$ \\
\hline
\end{tabular}

Fonte: Choo (2002, p.90).

b) Inteligência competitiva (competitive intelligence): tem uma boa definição de Bernhrdt (1994, p.13 apud CHOO, 2002) - processo analítico que transforma concorrentes, indústria e dados de mercado em estratégias conhecidamente acionáveis sobre as capacidades, intenções, resultados e posição dos concorrentes.

c) Business intelligence: com significado mais abrangente, tem sido definido como a atividade de monitorar o ambiente externo para captar informações que são relativas para processos de decisão da organização (GILAD \& GILAD, 1988 apud CHOO, 2002).

\section{Quadro 3: O domínio do Business Intelligence}

\begin{tabular}{lll}
\hline Concorrentes atuais & $\circ$ Ambiente econômico \\
$\circ$ Concorrentes potenciais & $\circ$ Ambiente social e comunitário \\
$\circ$ Oportunidades de crescimento & $\circ$ Índices demográficos \\
$\circ$ Mercados & $\circ$ Fornecedores \\
$\circ$ Políticas e regulamentações ambientais & $\circ$ Candidatos à aquisição
\end{tabular}

Fonte: Choo (2002, p.91). 
d) Gerenciamento de questões (issues management): seu papel é desenvolver políticas da empresa e suportar programas de caráter socioeconômico que poderão afetar a futura viabilidade da organização.

e) Rastreamento do ambiente (environmental scanning) ou rastreamento: é parte do processo da estratégia de decisão e deve analisar a seleção de uma série de fontes de informação. Qualquer mudança no ambiente externo cria sinais e mensagens que uma organização deve trabalhar (DILL, 1986 apud CHOO, 2002). Alguns desses sinais são fracos (difíceis de serem detectados), muitos são confusos (difíceis de serem analisados) e outros são espúrios (não indicam necessariamente uma mudança real). Na busca de informações, as organizações teriam de ser capazes de trabalhar com uma grande quantidade de sinais criados por um ambiente dinâmico, interpretá-los mesmo que provavelmente confusos e criar sentido em informações que se relacionam a metas e atividades da organização. O Quadro 4 demonstra esses aspectos: 


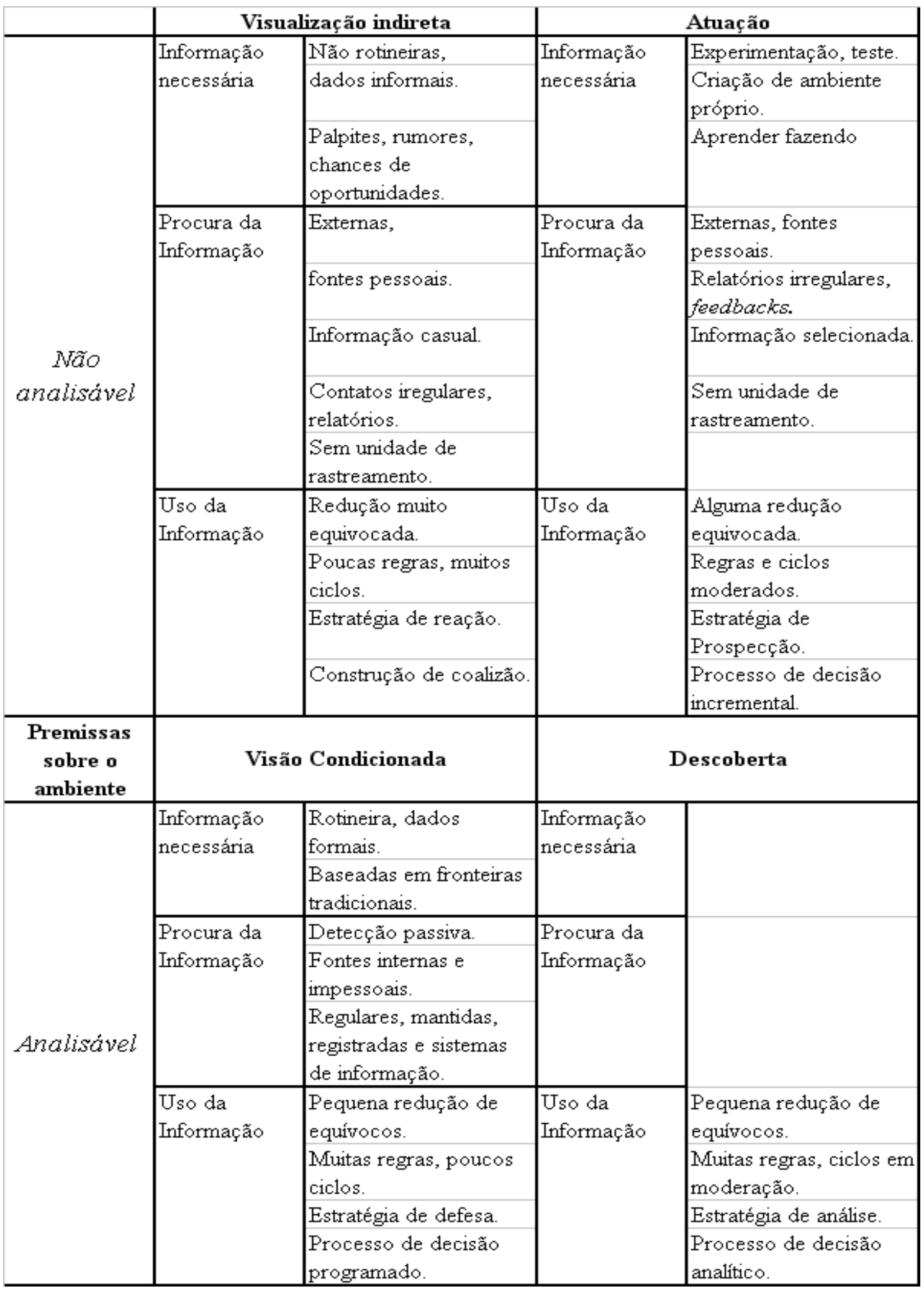

Quadro 4 - Modos de rastreamento e interpretação

Fonte: Choo (2002, p.95). 
f) Inteligência social (social intelligence): tem o escopo e a visão mais abrangentes, o que significa que a sociedade e as instituições têm capacidade de identificar problemas, coletar informações relevantes sobre esses problemas, transmitir, processar, avaliar e finalmente colocá-las em uso. O termo tem sido utilizado para descrever a capacidade de um país em utilizar a informação com o objetivo de alcançar estratégias nacionais.

Blanco et al (2003) propõem a construção de uma série de ferramentas como em uma visão de uma plataforma de engenharia de tecnologia. Essas ferramentas devem enriquecer e formar, provavelmente, uma plataforma tecnológica de IC. Os autores dizem apontam uma distância entre os problemas práticos e a literatura científica sobre o assunto, o que os faz propor o protótipo de um modelo que possa diminuir essa distância e facilitar a absorção, pelas empresas, dos métodos criados no ambiente acadêmico. "O nosso objetivo é melhorar a situação sob o ponto de vista dos praticantes e coletar dados do que é satisfatório ou insatisfatório no novo método". A Ilustração 6 é uma representação do que é denominado pelos autores de Management engineering aproach.

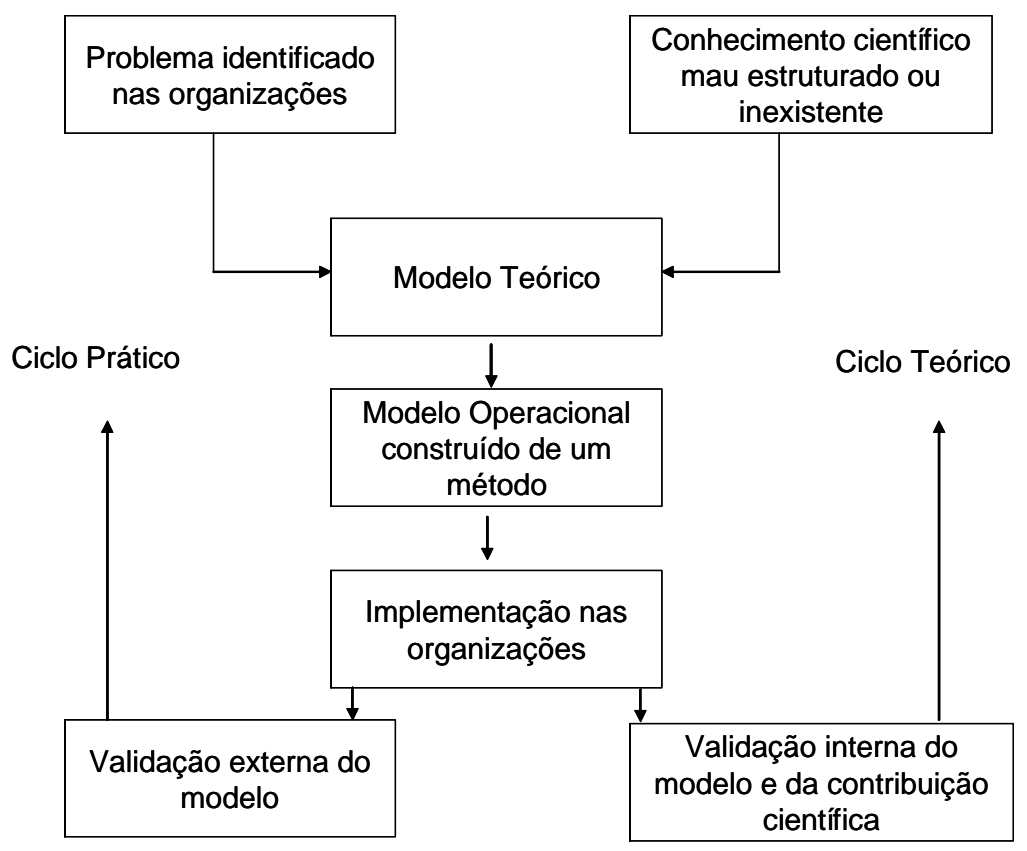

Ilustração 6 - Estágios no gerenciamento da engenharia de pesquisa.

Fonte: Blanco (2003, p.86).

Prescott \& Miller (2002) descrevem quatro lições abrangentes para auxiliar as empresas na implementação de seus esforços de IC: 
a) Programas de IC exigem um papel claramente articulado, que decorre do processo de reconhecer as necessidades de informação dos integrantes da organização. Sem isso, um programa de IC falhará ou, pior ainda, se tornará um centro de pedidos ad hoc.

b) O conjunto de resultados de um programa de IC deve ser disseminado oportunamente, apresentando implicações acionáveis e sendo visto como merecedor de credibilidade e confiança:

- Um trabalho de inteligência deve ser emoldurado por uma ferramenta analítica;

- A comunicação eficaz domina a análise;

- Falhas éticas comprometerão a credibilidade e a confiança.

c) Nas organizações, uma cultura impulsionada pela inteligência é construída passo a passo, uma pessoa de cada vez, com o aprimoramento das qualificações relativas ao trato das informações, a formação de redes de contatos pessoais e os mecanismos que facilitam o fluxo de informações.

d) A evolução dos programas de IC é um fenômeno natural impulsionado pelas necessidades da empresa, pelo feedback e por técnicas de melhoria da qualidade. A Ilustração 7 a seguir detalha o que os autores descrevem neste item.

\begin{tabular}{|c|c|c|}
\hline $\begin{array}{l}\text { Propulsores da } \\
\text { evolução }\end{array}$ & $\begin{array}{l}\text { Que tipo de grupo de IC } \\
\text { queremos ser? } \\
\text { (Visão) }\end{array}$ & \\
\hline 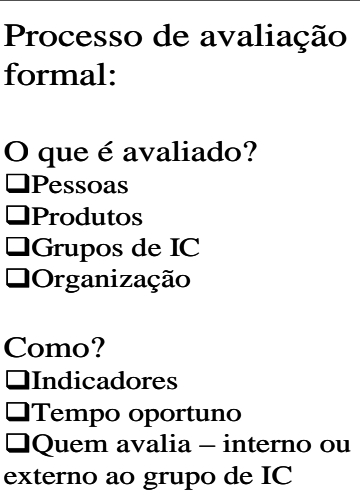 & $\begin{array}{c}\text { Onde estamos agora e quais } \\
\text { são nossas limitações? } \\
\text { Como nossos esforços } \\
\text { contínuos de } \\
\text { aperfeiçoamento nos } \\
\text { ajudam a alcançar a visão? }\end{array}$ & $\begin{array}{l}\text { Avaliação Informal } \\
\square \text { Grupos de IC } \\
\square \text { Outros } \\
\square \text { Relação com equipes da } \\
\text { alta gerência }\end{array}$ \\
\hline $\begin{array}{l}\text { Por quê? } \\
\text { 口Resolução de problemas } \\
\text { 口Busca de melhoria }\end{array}$ & & \\
\hline
\end{tabular}

Ilustração 7 - Evolução de programa de IC (PRESCOTT \& MILLER, 2002). 
Para Liu (1998), um sistema de rastreamento e interpretação serve como percepção, identificação e significado, para prover informações, para criar uma base para a formulação de estratégias para empresas. Esse sistema é útil para detectar alterações e desenvolvimento no ambiente e problemas de funcionamento na organização. É suposto que o rastreamento seja capaz de aprender sobre o futuro e ser capaz de projetar e dar forma a ele para vantagem própria. O modelo conceitual proposto pelo autor para rastreamento e interpretação está demonstrado na Ilustração 8:

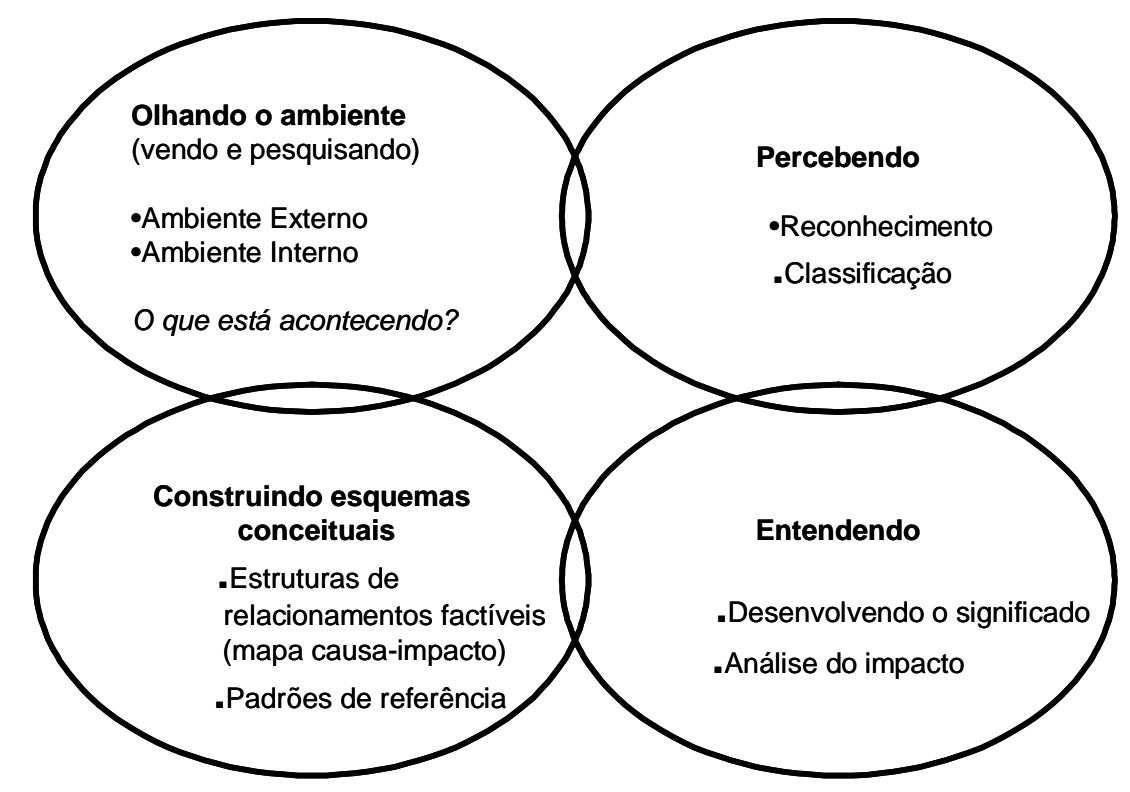

\section{Ilustração 8 - Conceito de rastreamento e interpretação.}

Fonte: Liu (1998, p.299).

Liu (1998) considera esse modelo de aprendizagem como um ambiente de rastreamento que uma corporação deveria perseguir, em razão de não somente ajudar os usuários a encontrar ou pesquisar informações, mas também em torná-lo um processo contínuo de aprendizagem para gerentes, transformando sinais antecipativos em vantagens antecipativas contínuas.

O autor afirma que o processo de um agente inteligente de software, rodando autonomamente para cumprir essas tarefas, seria capaz de cumprir esse processo, contínuo também, de uma forma mais eficiente. Um agente de software é definido analogamente como um programa computacional que age para executar uma tarefa em favor do usuário com algum grau de autonomia e, fazendo isso, emprega algum conhecimento ou representação de desejos e metas dos usuários. 
Os agentes de software, também denominados inteligentes, serão detalhados num próximo tópico.

Comparando os modelos descritos acima, optamos pela utilização do modelo descrito por Blanco et al (2003), que segue a metodologia de Lesca (2003), com etapas de rastreamento e filtro de informações, atores, rastreadores e foco mais bem definidos. Este trabalho tratará exatamente dessas fases e da utilização dos conceitos descritos pelos autores.

\subsection{O modelo de Lesca}

\subsubsection{Primeira etapa - Escolha do domínio da aplicação}

Em seu livro de 2003, Lesca denomina de LESCanning ${ }^{\circledR}$ sua metodologia para o tratamento de informações da Inteligência Competitiva nas organizações. A primeira decisão a ser tomada deve ser a definição de uma estrutura que será responsável por realizar as tarefas de Monitoramento Antecipativo Estratégico - Inteligência Competitiva (MAE-IC), incluindo a subordinação a essa estrutura. O posicionamento do grupo de MAE-IC varia com a dimensão da organização, podendo existir mais de um grupo simultaneamente.

A quantidade de grupos combinada com o tamanho de cada um e o seu posicionamento hierárquico é que determinará o que o autor denomina "domínio da aplicação" do MAE-IC na organização.

\subsubsection{Segunda etapa - Amplitude do processo do MAE-IC}

O termo amplitude é empregado neste contexto para designar a delimitação das fronteiras de atuação do grupo MAE-IC, sendo explicitado por meio de uma lista das pessoas que poderão contribuir ou se beneficiar com os resultados das atividades:

a) os responsáveis e suas hierarquias;

b) os profissionais que comporão o grupo;

c) os futuros utilizadores potenciais das informações.

\subsubsection{Terceira etapa - Organização e dinâmica de animação}

A nomeação de um animador do projeto, o profissional que insufla vida ao processo de MAEIC e à estrutura técnico-organizacional que lhe dá suporte, é a terceira etapa do processo. Sem um responsável oficial, claramente designado e reconhecido pela hierarquia e seus membros, 
o processo correrá o risco de não funcionar de forma durável, dada a sua estrutura matricial, com áreas diferentes envolvidas.

\subsubsection{Quarta etapa - Definição do foco para o MAE-IC}

O ambiente organizacional é constituído por atores, que são entidades ligadas a determinadas informações. O interesse nas informações pode variar, dependendo do tipo de ator envolvido no processo. São exemplos de atores: concorrentes, clientes, fornecedores, acionistas e investidores.

Conceito de ator: os atores podem ser pessoas físicas ou jurídicas, externas às fronteiras do monitoramento estratégico, cujas decisões e ações podem exercer influência direta ou indireta no futuro da organização. Estes atores devem ser nomeados, identificados e caracterizados, no mínimo, por nome e endereço (como encontrá-los, caso necessário, ou mesmo para caracterizá-los com maior precisão). Termos genéricos como "mercado" ou "a concorrência" devem ser excluídos.

Conceito de tema: um tema é o centro de interesse que pode influenciar o futuro, podendo ser identificado de diversas formas:

a) em relação a um ato específico;

b) em relação a vários atores simultaneamente;

c) sem referência a nenhum ator em particular. Por exemplo, quando os atores não são conhecidos, mas potenciais.

São exemplos de tema:

a) pesquisas de um laboratório que estejam em andamento;

b) projeto de lançamento de um novo produto por um concorrente;

c) informações da concorrência sobre fusões e cisões de empresas.

Conceito de foco: a construção de um foco no MAE-IC é a operação pela qual se delimita o ambiente externo à empresa sobre o qual há um interesse comum dos membros do grupo. Construir um foco de MAE-IC significa exprimir, de modo explícito e formal, o que pode interessar a todos os participantes do processo. 
Existem três razões principais para a construção de um foco para o MAE-IC:

a) superar o desafio da necessidade de informação do dirigente. Normalmente os decisores têm dificuldades para discernir, de maneira clara e precisa, quais são as informações estratégicas antecipativas realmente necessárias. A definição do foco é como a definição do escopo de um projeto: caso ela não seja formalizada claramente, qualquer necessidade pode surgir no caminho e os participantes podem não se sentir atendidos pelo projeto, ou mesmo haver identificações errôneas das verdadeiras necessidades;

b) a determinação do foco é o que permite definir coletivamente a partição do ambiente sobre o qual se deve concentrar a atenção. A atenção é a aptidão de observar e tentar compreender um fenômeno suscetível de ser produzido em um ambiente. É também a ferramenta mais importante na captação de informações ditas informais, que estimulam decisões, que podem ser consideradas até as mais importantes, que são mais abundantes, mas as que mais facilmente se perdem;

c) utilizar os recursos dedicados ao MAE-IC da melhor forma possível. Os recursos dedicados ao MAE-IC e os prazos esperados para que existam resultados concretos definem a necessidade de se delimitar a amplitude do projeto.

O resultado da operação de foco é constituído por um ou mais dos seguintes documentos:

a) lista de atores;

b) lista de temas;

c) tabela de combinação "foco $\mathrm{x}$ atores $\mathrm{x}$ temas";

d) lista de pessoas motivadas por um ou mais atores ou por um ou mais temas;

e) linha de raciocínio que levou à escolha de atores e temas;

f) glossário de termos e temas;

g) lista das fontes de informação a pesquisar.

\section{Dimensão do foco}

A dimensão do foco é caracterizada pelo número de atores, temas e fontes e de onde se esperam que venham as informações necessárias. Esta dimensão pode variar em função do estágio em que se encontra a evolução da estrutura de monitoramento. 


\subsubsection{Quinta Etapa - Criação coletiva de sentido}

A criação coletiva de sentido é a fase na qual é criado o "sentido acrescentado", o conhecimento a partir de certas informações que desempenham o papel de indutores do estímulo e através de interações entre os participantes da sessão de trabalho coletivo, assim como entre os participantes e as diversas memórias (tácitas e formais) da empresa.

O objetivo fundamental da criação coletiva de sentido é a transformação das informações antecipativas (entre elas os sinais fracos) em forças motrizes úteis para a ação dos responsáveis.

O resultado é a formulação de conclusões provisórias plausíveis (hipóteses) antes da partida para ações efetivas. É também a criação coletiva de conhecimentos. Para ajudar as empresas nesta etapa, Lesca (2003) propõe o método PUZZLE ${ }^{\circledR}$ (quebra-cabeça), que permite estruturar a reflexão coletiva do grupo de trabalho.

Quando do término da criação coletiva de sentido, os produtos finais devem atingir os objetivos de passar à ação e fazer emergir uma inteligência coletiva na empresa.

\subsubsection{Sexta etapa - Organizar e dar continuidade ao rastreamento das informações, do individual ao coletivo}

O rastreamento é a operação voluntarista (proativa) que objetiva que os membros da empresa percebam, escolham ou provoquem informações. A palavra rastreamento foi escolhida para significar que as informações mais interessantes do MAE-IC não vêm por si mesmas até os profissionais. Ao contrário, é necessário um esforço voluntarista:

a) de exposição deliberada à informação;

b) de provocar legalmente informações que não existem a priori;

c) de perceber informações onde elas não são automaticamente evidentes;

d) de reter (eleger) algumas entre elas.

Os rastreadores podem ser externos ou internos à empresa e sedentários (freqüentemente são profissionais de informação, que receberam formação apropriada e acessam documentos, base 
de dados, Internet e outros) ou internos à empresa e de campo (normalmente em deslocamento, suas fontes de informações residem principalmente em contatos com pessoas de naturezas diversas, clientes, fornecedores, concorrentes, laboratórios, feiras, congressos e outros). Estes últimos geralmente não receberam nenhuma formação no campo da informação.

\subsubsection{Sétima etapa - Implementação da seleção de informações}

A seleção das informações é a operação que consiste em reter somente aquelas que podem interessar aos usuários potenciais dentro do perímetro MAE-IC. Existem pelo menos dois critérios para que uma informação seja retida: o caráter antecipativo e a pertinência.

A seleção é coletiva e apresenta muitas vantagens para o desenvolvimento de um aprendizado coletivo e para aumentar a confiabilidade das informações. Por outro lado, ela pode ser vista como dispendiosa em termos do tempo dos especialistas. Devido a esse fato, essa seleção coletiva será preferida por empresas preocupadas acima de tudo com a utilização realmente eficaz da informação.

\subsubsection{Oitava etapa - Organização da memória do MAE-IC}

A memória da organização é a representação durável, explícita, despersonalizada de seus conhecimentos e das informações que facilite o acesso, o compartilhamento e a reutilização pelos profissionais corretos na organização. Esta descrição, que está limitada somente a uma parte da memória da organização, é justamente a que corresponde aos limites da estrutura de MAE-IC.

As informações em si não são suficientes para a criação coletiva de sentido. É da maior importância o cruzamento destas com os conhecimentos tácitos e as experiências de vários membros da organização, se possível complementares em termos de conhecimento.

Os conhecimentos úteis para criar coletivamente o sentido e explorar as informações MAE-IC devem ser:

a) Conhecimentos provenientes de diversas pessoas, por definição, da inteligência 
coletiva;

b) Conhecimentos ligados ao saber da experiência vivida pelas pessoas, portanto conhecimentos originalmente tácitos;

c) Conhecimentos que as detêm, provavelmente espalhados no domínio de aplicação do MAE-IC.

\subsubsection{Nona Etapa - Difusão das informações e do conhecimento produzido}

A difusão é a operação que consiste em colocar à disposição dos usuários potenciais as informações e os conhecimentos resultantes principalmente da criação coletiva de sentido. Estes usuários são, freqüentemente, os responsáveis operacionais. É o gestor do armazenamento de informações e de conhecimento que tem a iniciativa da operação de difusão. Difundir de forma eficaz significa:

a) As informações devem ser claramente compreendidas por seus destinatários.

b) Será efetivamente levado em conta pelos usuários em potencial o seu comportamento de aceitação ou de recusa em relação à informação recebida.

O ponto de partida dessa operação é o local onde estão armazenadas as informações elaboradas, enquanto o ponto de chegada é o local onde essas informações serão utilizadas pelos usuários potenciais, que podem ser denominados Clientes da MAE-IC.

\subsubsection{Décima etapa - Avaliação do resultado}

O responsável pelo grupo de MAE-IC certamente se defrontará com as seguintes questões:

a) Os objetivos foram atingidos?

b) Como medir os resultados?

O método LESCAnning ${ }^{\circledR}$ propõe quatro níveis de avaliação de resultados, apresentados a seguir em ordem decrescente de ambição:

a) O MAE-IC tem se traduzido em bons resultados para a empresa ou para unidade a que está vinculado? 
b) O MAE-IC tem contribuído para o desenvolvimento de uma inteligência coletiva na organização?

c) O MAE-IC tem aumentado a qualidade das informações antecipativas sobre o ambiente da empresa?

d) O processo MAE-IC tem funcionado corretamente?

As respostas positivas a estas questões devem vir acompanhadas de indicadores que as comprovem. Tais indicadores podem ter as mais diversas naturezas, mas geralmente devem refletir o desempenho global da empresa ou unidade de negócios, tais como os indicadores de geração de lucro, redução de custos e efetividade administrativa.

\subsection{A Internet como fonte de informações para Monitoramento estratégico}

Devido ao fato de que a Internet está se tornando um elemento indispensável de comunicação diária, muitos dos fatos que estão para surgir no mundo real já deixaram suas marcas nesse mundo virtual (DECKER et al, 2005).

Tendências em negócios, ciência, sociedade, política e tecnologia são digitalmente anunciadas na Internet, principalmente na World Wide Web (WWW). O espectro da informação digital vai de publicações de institutos de pesquisa, relativas a invenções de novas tecnologias e declarações de fundo político, até estudos empíricos em vários tópicos de mercado. Infelizmente, muitas dessas tendências são nebulosas, e mais fortemente incompreensíveis do que ruídos no sistema, quando consideradas separadamente (DECKER et al, 2005).

O autor diz buscar um sistema automático para prover informações com o mínimo de esforço humano para a busca de informações competitivas na Web. Segundo ele, rastrear documentos de interesse com mecanismos de busca como Google ou AltaVista consome muito tempo e nem sempre leva a um resultado acertado. Novos documentos aparecem na Web a cada segundo, os existentes são modificados ou excluídos. Por esse motivo, utilizar esses mecanismos de busca para Monitoramento estratégico de forma a serem controlados e ajustados pelo usuário é no máximo paliativo.

Chen et al (2002) descrevem uma pesquisa com mais de 300 profissionais de Monitoramento estratégico, que mostrou que mais de $30 \%$ do tempo de um projeto é utilizado para rastrear informações. Esses profissionais estão investindo muito mais tempo em coletar do que em 
analisar informações. Esse problema se torna ainda maior quando se trata da Internet, devido à enorme carga de informações, que ainda sofrem atualizações a cada semana, dia, hora ou minuto. Para resolver essa situação, estão sendo realizadas pesquisas para o desenvolvimento de técnicas e ferramentas para analisar, categorizar e visualizar grandes coleções de páginas Web, entre outros tipos de documentos.

\subsection{Inteligência Artificial}

Uma definição de Inteligência Artificial (IA), dada por Zwicker (2005) é de que se trata do estudo de como fazer o computador realizar tarefas para as quais, atualmente, o homem ainda pode ser considerado melhor. Sua origem, com perspectivas bastante otimistas, deu-se no início da década de 1960, com problemas a serem resolvidos baseados em jogos e teoremas considerados de progresso lento.

São consideradas, ainda, pelo autor, três visões sobre IA:

a) Máquinas que pensam e aprendem, programas exóticos e sem resultados práticos;

b) Considerar como questão combinatória, enumerar soluções e escolher a melhor e explosão combinatória;

c) Conjunto de técnicas computacionais para representar o conhecimento e pesquisar soluções.

Durante milhares de anos, procuramos entender como pensamos; isto é, como um mero punhado de matéria pode perceber, compreender, prever e manipular um mundo muito maior e mais complicado que ela própria. O campo da Inteligência Artificial vai ainda além: ele tenta não apenas compreender, mas também construir entidades inteligentes. (RUSSEL, 2003)

Russel (2003) descreve algumas definições de IA através do Quadro 5, onde, em linhas gerais, as que estão na parte superior se relacionam a processos de pensamento e raciocínio, enquanto as definições da parte inferior se referem ao comportamento. As do lado esquerdo medem o sucesso em termos de fidelidade ao desempenho humano, enquanto as definições do lado direito medem o sucesso comparando-o ao conceito ideal de inteligência humana, chamada pelos autores de racionalidade, ou seja, "um sistema é racional se faz tudo certo com os dados que tem". 


\section{Quadro 5 - Algumas definições de IA}

\begin{tabular}{|c|c|}
\hline Sistemas que pensam como seres humanos & Sistemas que pensam racionalmente \\
\hline $\begin{array}{l}\text { "O novo e interessante esforço para fazer os } \\
\text { computadores pensarem... máquinas com } \\
\text { mentes, no sentido total e literal." } \\
\text { (HAUGELAND apud RUSSEL, 2003) }\end{array}$ & $\begin{array}{l}\text { "O estudo das faculdades mentais pelo uso de } \\
\text { modelos computacionais". (CHARNIAK \& } \\
\text { MCDERMOTT, 1985) }\end{array}$ \\
\hline $\begin{array}{l}\text { "[Automatização de] atividades que } \\
\text { associamos ao pensamento humano, } \\
\text { atividades como a tomada de decisões, a } \\
\text { resolução de problemas, o aprendizado..." } \\
\text { (BELLMAN, 1978) }\end{array}$ & $\begin{array}{l}\text { "O estudo das computações que tornam } \\
\text { possível perceber, raciocinar e agir" } \\
\text { (WINSTON, 1992). }\end{array}$ \\
\hline Sistemas que atuam como seres humanos & Sistemas que atuam racionalmente \\
\hline $\begin{array}{l}\text { "A arte de criar máquinas que executam } \\
\text { funções que exigem inteligência quando } \\
\text { executadas por pessoas". (KURZWEIL, } \\
\text { 1990) }\end{array}$ & $\begin{array}{l}\text { "A Inteligência Computacional é o estudo do } \\
\text { projeto de agentes inteligentes". (POOLE et } \\
\text { al, 1998) }\end{array}$ \\
\hline
\end{tabular}

Fonte: Russel (2003).

O conceito que será utilizado neste trabalho segue a definição do canto inferior direito do Quadro 5, relativa a sistemas que atuam racionalmente, de que é "o estudo do projeto de agentes inteligentes" (POOLE et al, 1998).

\subsection{Agentes inteligentes, agências e conhecimento}

\subsubsection{Agentes e a comparação com a mente humana por Marvin Minsky}

Minsky (2000) diz que somos capazes de resolver problemas de ordem matemática ou física e que temos capacidade de resolver vários tipos de raciocínios lógicos sobre esses assuntos. Mas, nem sempre somos capazes de resolver problemas comuns do mundo real.

$\mathrm{O}$ autor discute a questão da pesquisa da Inteligência Artificial e relata que, nos primeiros anos, foram resolvidos problemas simples, como provar um teorema ou ganhar um jogo de xadrez, por exemplo. Esses programas especialistas usavam procedimentos que trabalhavam 
em um mundo pequeno, enquanto problemas de pensamentos de senso comum normalmente envolvem um conjunto muito mais largo de conhecimento e habilidade.

Pensamentos de senso comum referem-se a coisas que muitas pessoas podem fazer frequentemente, sem nem perceberem que estão fazendo.

Em entrevista concedida por Minsky a Riecken (1994) sobre agentes, o entrevistador faz referência à forma como o autor descreve a inteligência humana, através de agentes e agenciamento, não como máquinas inteligentes, mas como representantes da aquisição do conhecimento, comparando a inteligência humana com o que os agentes computacionais seriam capazes de fazer (MINSKY, 1986).

[...] em Society of Mind (MINSKY, 1986) a idéia foi utilizar a palavra agente quando você deseja fazer referência à uma máquina que realiza algo, sem você saber exatamente como ela trabalha. Você chama de agente quando você deseja tratá-lo como uma caixa-preta... em outras horas seu objetivo pode requerer conhecer mais sobre o que está nesta caixa-preta contendo o agente - e é neste caso que você deseja vê-lo como uma agência... a melhor forma de fazer isto é, usualmente, analisá-lo - isto é, quebrá-lo em partes e entender como elas interagem. (MINSKY, 1986)

Minsky (1986) ainda descreve que, em seu livro, utilizou o termo agência, que sugere a imagem de uma organização composta de vários subagentes interagindo.

Nessa mesma entrevista a Riecken (1994), o autor descreve os agentes computacionais como um sistema que pode desempenhar um papel intermediário entre inteligência humana e computacional por possuírem algumas capacidades especializadas. Ainda em resposta ao entrevistador, Minsky diz:

[...] quando necessitamos de máquinas somente para resolver problemas especializados somos capazes de construir um programa que ajudará a resolvê-los. Mas, quando se trata da necessidade de ser um assistente capaz de ter uma inteligência generalizada, nenhuma máquina presente ajudará, porque lhes falta o que chamamos de senso comum. Basicamente, refere-se a um tipo de coisas que qualquer criança conhece que inclui saber muito sobre tempo e espaço, sobre propriedades de materiais conhecidos, sobre necessidades e desejos de uma pessoa típica e sobre muitas formas de resolver problemas e ultrapassar resultados. (MINSKY em entrevista a RIECKEN, 1994)

Em seu livro, Minsky (1986) denomina as pequenas partes que constroem a mente, cada uma sem funcionar como mente por si mesma. Ele chama esse esquema de "sociedade da mente", onde cada mente é feita de pequenos processos, que serão denominados "agentes". Quando esses agentes se juntam em sociedades — numa forma especial —, isso leva à verdadeira inteligência.

Minsky (1986) utiliza esses processos da mente para explicar o porquê da dificuldade de 
construirmos máquinas ou programas capazes de simular um ser humano. Nas primeiras seções do livro, o autor utiliza a construção de uma torre por crianças, utilizando blocos, para quebrar processos em partes menores e vermos como cada uma delas se relaciona com todas as outras partes.

Imagine uma criança brincando com blocos de madeira para construir uma torre. Nesse instante, vamos denominar o agente de construção desse bloco de Construir. Na verdade, construir uma torre é uma tarefa mais complicada quando vista com mais detalhes. $\mathrm{O}$ agente Construir tem que pedir ajuda para outros agentes:

a) Escolher um lugar para iniciar a torre (Iniciar);

b) Adicionar um novo bloco à torre (Adicionar);

c) Decidir se a torre já está suficientemente alta (Terminar).

Representado na Ilustração 9:

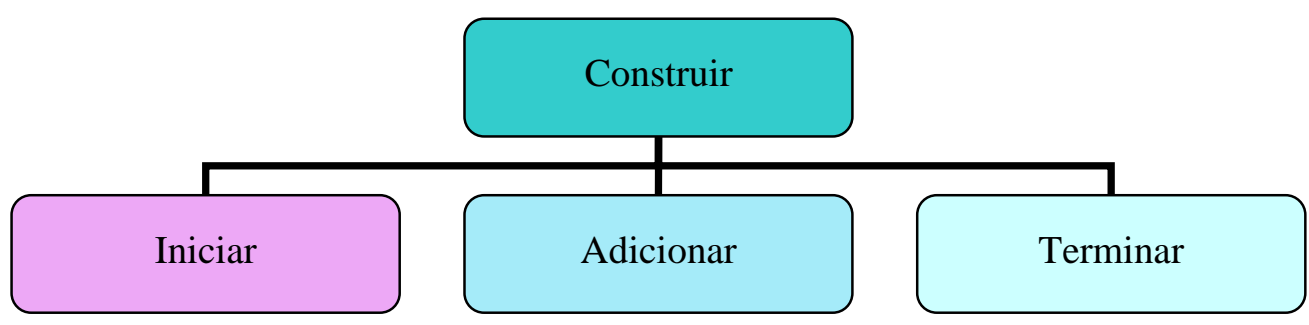

Ilustração 9 - Representação do agente Construir.

Fonte: Minsk (1986).

Na verdade, o agente Adicionar deve ser dividido em outros agentes, conforme demonstrado na Ilustração10:
a) Primeiro, Adicionar deve Encontrar um novo bloco;
b) Então a mão deve Pegar esse bloco;
c) E Colocar em cima da torre. 


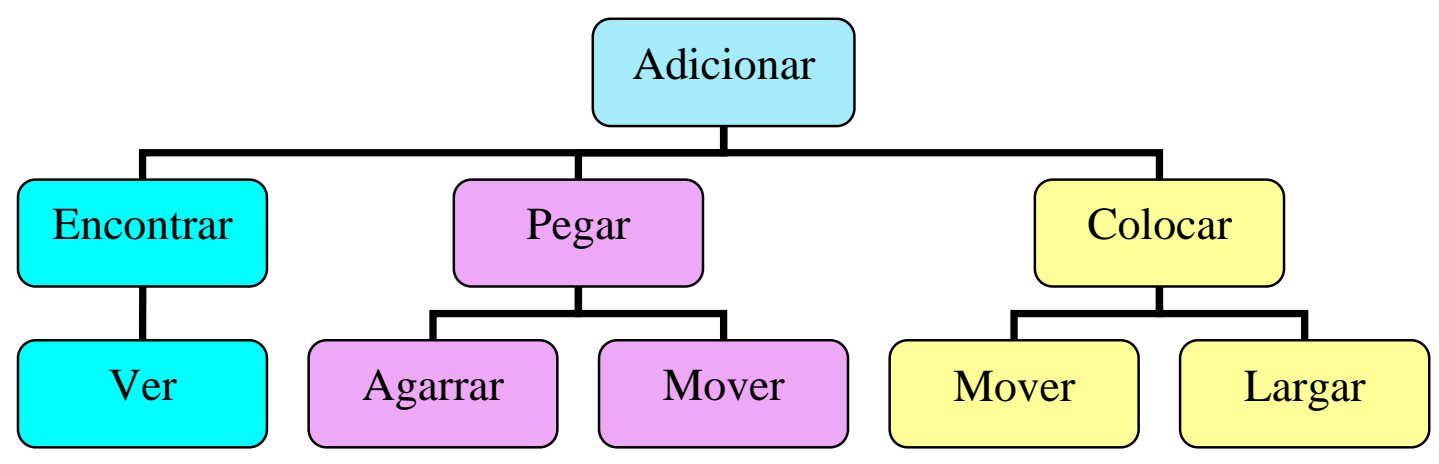

\section{Ilustração 10 - Representação do agente Adicionar.}

Fonte: Minsk (1986).

Minsky (1986) questiona por que quebrar as coisas em partes pequenas como essas e responde que as mentes funcionam dessa forma e que, embora os adultos saibam como fazer tais coisas, ninguém entende como nós aprendemos a fazer isso. As capacidades necessárias para se construir uma pilha de blocos foram adquiridas há tanto tempo, que não somos capazes de lembrar como, afinal, as desenvolvemos. Elas, agora, nos parecem senso comum e assumimos que todas estiveram sempre em nossas mentes, e nunca paramos para pensar em como começaram e se desenvolveram.

Segundo o autor, senso comum não é uma coisa simples, mas uma imensa sociedade de dura aquisição de idéias práticas. Múltiplos aprendizados de regras e exceções, disposições e tendências, manter equilíbrio e checar resultados.

Voltando à questão dos agentes que compõem o agente Construir, visto de fora, com nenhuma idéia de como ele funciona dentro, teremos a impressão de que ele sabe como construir torres. Mas se pudermos ver o seu funcionamento a partir de dentro, certamente não encontraremos nenhum conhecimento lá. Veremos uma série de caminhos encadeados, arranjados de várias formas para tornar cada um deles ligado ou desligado. $\mathrm{O}$ agente Construir realmente sabe como construir torres? A resposta depende de como olhamos para isso. Vamos utilizar duas palavras: agente (como agente, ele não sabe nada) e agência (como agência, ele parece saber qual é o trabalho a fazer). Minsky (1986), para reforçar o conceito, diz: 
alguma coisa está errada com o volante e você deseja saber o que está acontecendo, é melhor você se lembrar que o volante é apenas um agente em uma grande agência: ele se torna uma manivela que mexe uma engrenagem para puxar a roda que manipula o eixo da roda. Claro, ninguém sempre terá esta visão macroscópica. Se você tiver todos estes detalhes em mente quando estiver dirigindo você, provavelmente, causará um acidente. Leva muito tempo para saber qual a forma correta de mexer a roda. Saber como, não é a mesma coisa que saber por quê. (MINSKY, 1986)

Minsky (1986) diz que coisas fáceis são difíceis, isto é, quando nossos sistemas começam a falhar é que procuramos a ajuda de agências envolvidas com o que chamamos de conscientização. Em sua opinião, estamos mais atentos a processos simples, que não funcionam bem, do que aos complexos, que trabalham tranquilamente.

Para os agentes, segundo o autor, as hierarquias nem sempre funcionam. Por exemplo, quando dois agentes necessitam utilizar capacidades um do outro, nenhum deles pode estar no topo da hierarquia. Ele descreve um exemplo, com a Ilustração 11 a seguir. Se, por exemplo, você questiona seu sistema de visão, questiona se os primeiros blocos à esquerda constituem-se de dois ou três blocos.

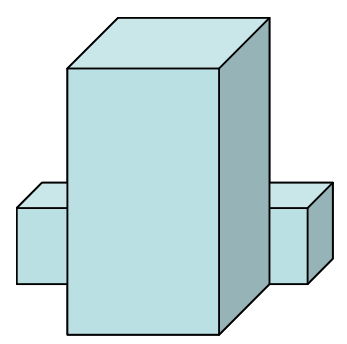

O que você vê

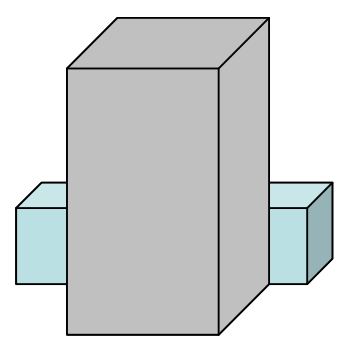

É isto?

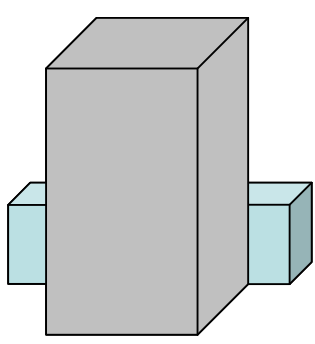

Ou isto?

\section{Ilustração 11 - Representação do agente See.}

Fonte: Minsk (1986).

O agente See poderia responder caso o agente Move pudesse mover o bloco da frente fora da linha de visão. Ao mesmo tempo, o agente Move precisaria ver (utilizar o agente See) se existe algum obstáculo que pudesse interferir na sua trajetória. Em algum momento, Move estaria trabalhando para See e See estaria trabalhando para Move, ambos ao mesmo tempo. Seria impossível representar esse problema em uma hierarquia (MINSK, 1986).

No artigo de 2000, Minsky pergunta e responde:

Por que não somos capazes, com o auxílio de nossos computadores, de saber este tipo de coisa ou aprender por observação? Estes computadores têm algum problema, que somente uma capacidade existente em cérebros humanos pode resolver? 
Não, estas limitações somente persistem porque nós temos aprendido apenas certas formas de programá-los. Por décadas nosso padrão de escrever programas para resolver um problema $P$ tem sido: encontre a melhor forma de representar $P$; encontre a melhor forma de representar o conhecimento necessário para resolver $P$, e encontre o melhor procedimento de resolver problemas como $P$.

Minsky (2000) escreve que existe alguma coisa de errado com essas regras: elas nos levam a escrever somente programas especializados, que resolvem somente determinado tipo de problema, o que nos deixa com milhões de programas especializados e especialistas.

Muita gente ainda acredita que não existem máquinas capazes de ter consciência, ou sentirem ambição, ciúmes, humor, ou ter experiência de vida mental. Para dizer a verdade, nós estamos ainda bem longe de sermos capazes de criar máquinas que sejam capazes de fazer tudo que as pessoas fazem. Mas, isto só significa que precisamos de teorias melhores sobre como o pensamento trabalha. (MINSKY, 1986)

O próximo item aborda a questão de como representar o conhecimento necessário para o desenvolvimento de agentes computacionais segundo Minsk e demais autores.

\subsubsection{Representações do conhecimento}

A melhor forma de representar o conhecimento tem sido primeiramente selecionar uma representação. Para Minsky (2000) este tem sido o problema, pois, caso usemos uma representação particular, rapidamente vamos encontrar alguma limitação ou restrição, acumulando-se até que o raciocínio comece a falhar.

Para o autor, parece que devemos utilizar várias representações para cada fragmento de conhecimento do senso comum sobre cada coisa, idéia ou relacionamento, ainda podendo mudar de um para outros métodos ou representações rapidamente. Importante, para isso, é conhecer quais métodos e representações são bons para cada conhecimento do senso comum, com o intuito de resolver vários tipos de problemas. Para isso existe a necessidade de se caracterizar os "tipos de problemas". O Gráfico 1, segundo Minsky (2000), representa, em um eixo, "a intensidade de fatores ou quantidade de causas envolvidas" e, no outro, "quanto efeito cada fator causa”. Para explicar melhor a relação entre esses eixos ele exemplifica da seguinte forma:

Suponha que você esteja em uma cama confortável. O que mantém você fora do chão? Resposta: você está suportado por milhões de pequenas forças, cada uma formada por minúsculas partículas que estão empurrando para cima alguma parte de sua pele. Esta força tem tão pouco efeito que, se qualquer delas fosse retirada, você jamais saberia que ela não está mais presente. Agora, o que mantém a cama em pé? Ela está sustentada somente por quatro pés fortes. Cada pé sustenta a cama com uma força bastante poderosa e remover qualquer um deles causaria um grande efeito. (MINSKY, 2000, p. 71) 
Poucas $\longleftrightarrow$ Número de causas $\longrightarrow$ Muitas

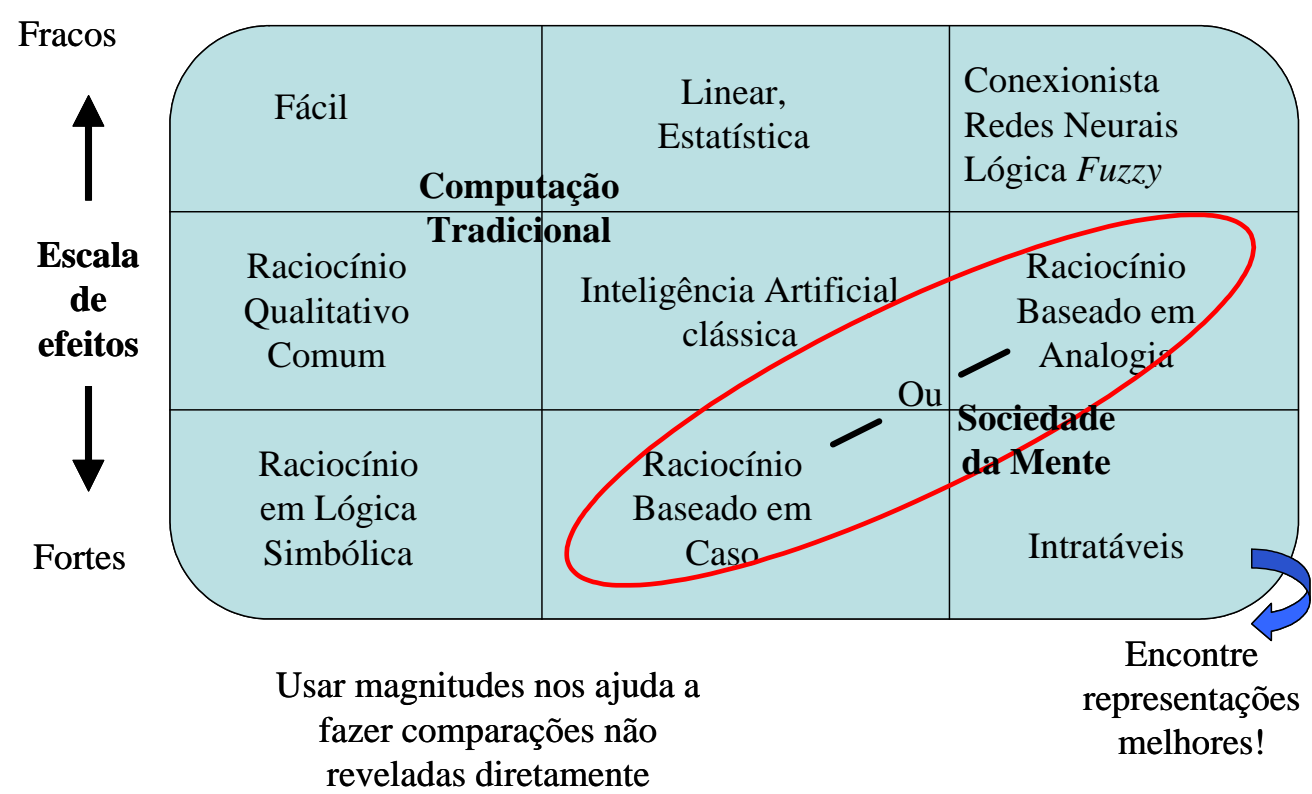

\section{Gráfico 1 - Matriz de diversas causas.}

Fonte: Minsky (2000, p. 71).

Minsky (2000) detalha o Gráfico 1: quando existem apenas algumas causas, cada uma com efeitos fracos (fácil), como exibido no canto superior esquerdo, então o problema será facilmente resolvível tanto por pesquisa exaustiva quanto por requisitar sucessivamente respostas.

Quando o caso for de muitas causas com efeitos fracos, então os métodos estatísticos e as redes neurais podem funcionar bem. No entanto, se estes sistemas têm suas causas com caracteres diferentes que interagem de formas difíceis de serem previstas, eles necessitam ser quebrados em subsistemas. Inclusive pelo fato de sistemas com passos à frente normalmente terem falhas de memórias de curto prazo, estes sistemas terminam por se dividir em problemas seqüenciais, e precisam ser gerenciados por sistemas externos.

Raciocínios em lógica simbólica (canto abaixo esquerdo da matriz) podem trabalhar muito bem quando existem apenas poucos fatores influenciadores - mesmo que cada um tenha grande efeito - , exceto no caso em que a pesquisa se transforme em dificuldade exponencial, em casos de processos seqüenciais. 
É raro que qualquer desses métodos tenha um bom funcionamento quando muitas causas têm fortes efeitos. A menos que o sistema seja linear, esses problemas podem parecer intratáveis, e talvez a solução seja representá-los através de várias formas que se alternem e permitam trabalhar com descrições mais claras.

A situação de múltiplas causas com efeitos modestos é aquela em que a Inteligência Artificial Clássica é mais bem sucedida, utilizando nosso conhecimento e experiência para construir e aplicar métodos de raciocínio baseado em analogias, planejamentos ou casos (Minsky, 2000).

A grande vantagem da representação do conhecimento e do processamento através do raciocínio baseado em casos ou analogias é a possibilidade de adicionar novas informações ao modelo sem ter que fazer grandes modificações no estado atual. Os autores dizem também que a infra-estrutura de conhecimento necessária em um sistema de Monitoramento estratégico ganha valor e é otimizada no uso de conjuntos relevantes de palavras-chave com técnicas de aprendizagem de máquina (machine learning) (Decker et al, 2005).

Segundo Minsky (2000), não existe a melhor forma de representar conhecimento. Falta à forma usual de representação a lógica puramente simbólica, a incerteza, conexões que nos ajudem a fazer novas hipóteses. Portanto, a proposta do autor é a de que cada tipo formal de inferência deveria ser complementado com tipos diversos de mecanismos, que incorporassem conexões heurísticas entre o conhecimento por si mesmo e o que esperamos obter dele.

Psicólogos e físicos, depois da ciência da computação ter abandonado o campo das redes neurais no final da década de 1970 , voltaram, na década de 80, a utilizar a técnica, quando pelo menos quatro grupos diferentes recriaram o algoritmo de aprendizado por retropropagação.

Os chamados modelos conexionistas para sistemas inteligentes eram vistos por alguns como concorrentes diretos dos modelos simbólicos e da abordagem logicista. A visão atual é de que as abordagens conexionista e simbólica são complementares e não concorrentes (RUSSEL \& NORVIG, 2003).

Os autores dizem ainda que, em parte, a IA surgiu como uma rebelião contra as limitações de áreas existentes, como a teoria de controle e a estatística, mas que agora ela inclui esses campos. David McAllester cita:

No período inicial da IA, parecia plausível que novas formas de computação simbólica, como 
frames e redes semânticas, tornariam obsoleta grande parte da teoria clássica. Isso levou a uma forma de isolacionismo na qual a IA ficou bem separada do restante da ciência da computação. Atualmente, esse isolacionismo está sendo abandonado. Existe o reconhecimento de que o aprendizado de máquina não deve ser isolado da teoria da informação, de que o raciocínio incerto não deve ser isolado da modelagem estocástica, de que a busca não deve ser isolada da otimização clássica e do controle, e de que o raciocínio automatizado não deve ser isolado dos métodos formais e da análise estatística. (MCALLESTER, 1998 apud RUSSEL \& NORVIG, 2003)

Alguns pesquisadores, de 1995 até a atualidade, começaram a examinar o problema do "agente como um todo". Esse movimento tem como objetivo entender o funcionamento interno de agentes incorporados a ambientes reais com entradas sensoriais contínuas (sistemas sensoriais como visão, sonar, reconhecimento da fala etc.) com um dos ambientes mais importantes para sua utilização: a Internet (RUSSEL \& NORVIG, 2003).

Podemos formalizar a visão abstrata de agentes com o objetivo de auxiliar a aprendizagem de como construir um agente inteligente. Uma das arquiteturas sugeridas por Wooldridge (2002) é a procedural. Portanto, para esse entendimento, serão necessárias algumas pré-definições.

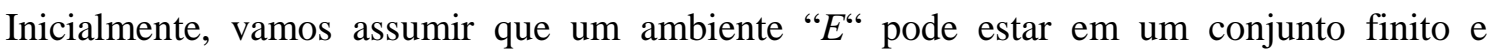
discreto de estados $E$ :

$$
E=\left\{e, e^{\prime}, \ldots\right\}
$$

Os agentes devem ter uma série possível de ações disponíveis, que transformam o estado de um ambiente. Seja:

$$
A c=\left\{\alpha, \alpha^{\prime}, \ldots\right\}
$$

Uma rodada do agente " $r$ ", de um agente em um ambiente $E$ é uma seqüência de estados do ambiente interpostos com ações:

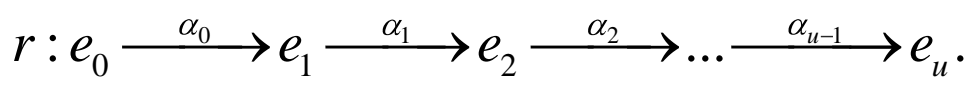

Seja:

a) $\quad R$ o conjunto de todas as possibilidades finitas de sequiências (sobre $E$ e $A c$ );

b) $\quad R^{\text {Ac }}$ o conjunto deste $R$, que termina em uma ação;

c) $\quad R^{E}$ o subconjunto deste anterior, que termina em um estado do ambiente.

Formalmente, o comportamento de um agente puramente reativo pode ser representado pela função:

$$
A g: E \rightarrow A c
$$


A Ilustração 12 a seguir (WOOLDRIDGE, 2002), representa um agente e seu ambiente. Os agentes levam sensores de entrada para o ambiente e, como saída, produzem ações que o afetam.

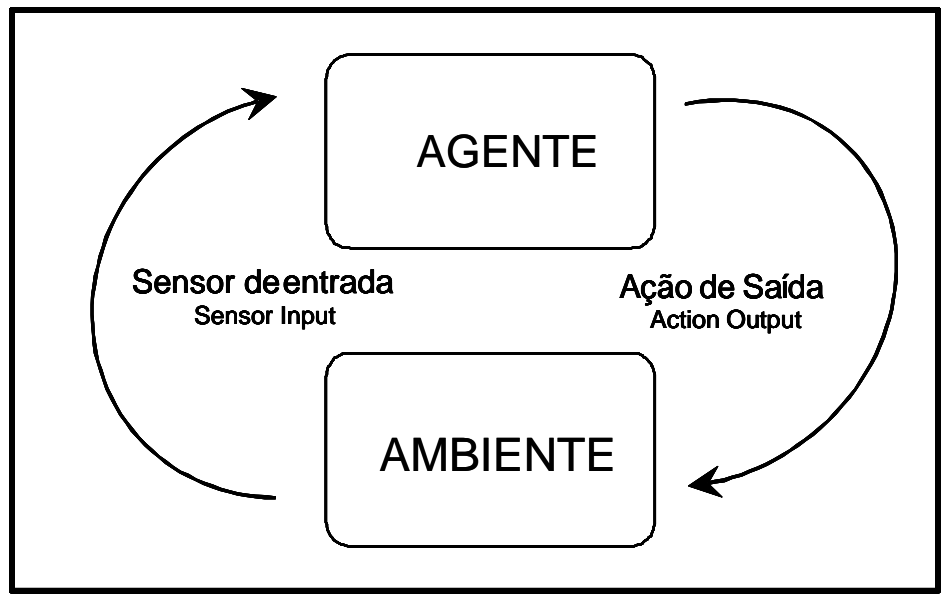

Ilustração 12 - Um agente e seu ambiente.

Fonte: Wooldridge (2002).

A figura dá uma visão abstrata de um agente puramente reativo. Podemos ver a ação de saída gerada pelo agente com o objetivo de afetar seu ambiente. Em muitos ambientes de complexidade razoável, um agente não terá controle total sobre seus ambientes. Ele terá, quando muito, um controle parcial, no qual poderá influenciá-lo.

A próxima figura separa uma função da decisão de um agente em subsistemas para percepção e ação:

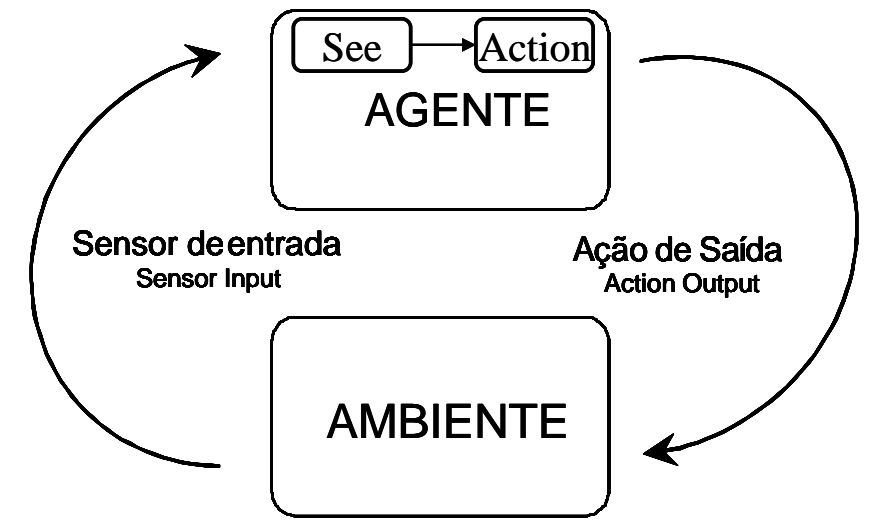

Ilustração 13 - Subsistemas de percepção e ação.

Fonte: Wooldridge (2002, p.34) 
A função see captura a habilidade de um agente para observar seu ambiente, e a função action representa o processo de decisão do agente de como agir. A resposta de uma função see é uma percept - uma percepção da entrada. Sendo Per um conjunto não vazio de percepções, então see é uma função definida como:

$$
\text { see }: E \rightarrow \text { Per }
$$

que mapeia estados do ambiente para as percepções; então, action será:

$$
\text { action : Per* } \rightarrow \text { Ac }
$$

onde $P e r^{*}$ é um subconjunto de Per.

A Ilustração 14 representa um agente com estados. Esses agentes têm algumas estruturas de dados internas, que são tipicamente utilizadas para registrar informações sobre o estado e o histórico do ambiente. Suponha $I$ o conjunto de todos os estados internos de um agente. Uma decisão do que fazer de um agente se baseia, pelo menos em parte, nessa informação. A função de percepção see para um agente baseado em um estado não se altera; continua a ser:

$$
\text { see }: E \rightarrow \text { Per }
$$

A função de ação selecionada action é definida como:

$$
\text { action }: I \rightarrow A c
$$

de estados internos para ações. Uma função adicional next é introduzida para mapear um estado interno e ter a percepção para um estado interno:

$$
\text { next }: I x P e r \rightarrow I
$$

O comportamento de um agente baseado em estado pode ser resumido da seguinte forma: um agente inicia em algum estado interno inicial $i_{0}$. Ele observa o estado do ambiente $e$, e gera see(e). O estado interno do agente é atualizado via função next, tornando-se conjunto para $\left(\operatorname{next}\left(i_{0}, \operatorname{see}(e)\right)\right)$. A ação selecionada pelo agente é então $\left(\operatorname{action}\left(\operatorname{next}\left(i_{0}, \operatorname{see}(e)\right)\right)\right)$. Esta ação é então executada e entra em novo ciclo, percebendo o mundo via see, atualizando seu estado via next e escolhendo uma ação via action. 


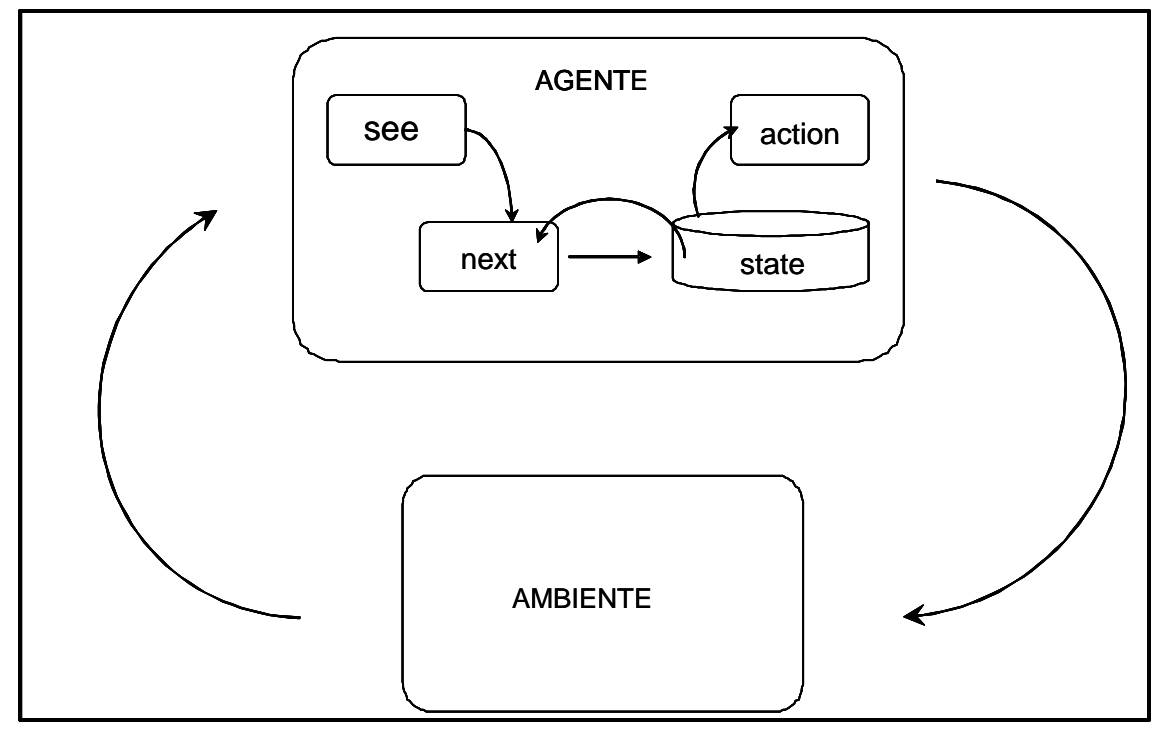

Ilustração 14 - Agentes que mantém estados.

Fonte: Wooldridge (2002, p. 36).

Existem formas diferentes de representação da ação dos agentes inteligentes em seus ambientes. As representações acima retrataram alguns poucos exemplos de necessidades de ações desses agentes, descritas por Wooldridge (2002) e consideradas pelo autor como fundamentais.

\subsubsection{Agentes são boas formas de recuperação de informação?}

Para a maior parte das aplicações, como uma folha de pagamento por exemplo, é inteiramente aceitável que os computadores são obedientes, literais e até serviçais. No entanto, para um grande número de aplicações, são necessários sistemas que possam decidir por si mesmos o que desejam fazer a fim de satisfazer seus objetivos. Esses sistemas de computador são conhecidos como agentes (WEISS, 1999).

O autor dá continuidade, dizendo que os agentes devem operar robustamente em mudanças bruscas, imprevisíveis ou ambientes abertos, onde existe uma possibilidade significativa de que ações possam falhar. Eles são conhecidos como agentes inteligentes ou, às vezes, como agentes autônomos. Ainda não existe um acordo universal para o termo "agente". Essencialmente, existe um consenso geral de que a autonomia é uma característica dos agentes inteligentes. 
Wooldridge \& Jennings (2003) definem agente inteligente: "Um agente é um sistema de computador que é situado em um determinado ambiente, que tem a capacidade de ações autônomas neste ambiente, em ordem de alcançar seus objetivos pré-definidos”.

Quando utilizamos uma query específica para encontrar uma informação na Web, ou mesmo utilizando instrumentos de busca já consagrados (Google, Yahoo etc.), podemos encontrar um processo bastante longo e tedioso, com a recuperação de muitas páginas de informação que nem sempre representam a necessidade real dos usuários.

A idéia poderia ser dar uma query a um agente para que ele faça a pesquisa, que poderia sintetizar pedaços de informação de várias fontes da Internet. Poderia haver falha quando uma fonte de um recurso particular não estivesse disponível, provavelmente devido a uma falha da rede, ou no local onde não pudessem ser obtidos resultados, diz Weiss (1999). O autor continua:

[...] computadores não são muito bons em decidir o que fazer: cada ação deve ser antecipada, planejada, configurada e codificada por um programador. Caso o programa de computador alguma vez encontre uma situação que não foi considerada, então o resultado nem sempre é positivo. Este fato mundano é o coração de nosso relacionamento com eles. (WEISS, 1999)

Para Russel \& Norvig (2003), um agente é algo que age (agente vem do latim agere, fazer):

Agentes de computadores ou computacionais têm atributos especiais esperados, que os distinguem de meros 'programas', assim como: operar sobre controle autônomo, percebendo seu ambiente, persistindo por um longo período, adaptando-se às mudanças e serem capazes de atingir objetivos de outros. Um Agente Inteligente assume a melhor ação possível em uma situação.

Uma forma muito parecida de denominação dos agentes de software são os programas computacionais ou entidades que agem para realizar tarefas especializadas em favor dos usuários. Eles parecem ter vários atrativos. Os agentes agem com algum grau de autonomia, no sentido de alcançar ou realizar certas especificações dos usuários ou metas geradas automaticamente (LIU, 1998).

Então, quando consideramos um agente inteligente? Certamente não em um caso como o do termostato. Para o propósito desta pesquisa, vamos assumir que um agente inteligente é capaz de ações flexíveis e autônomas com a meta de atingir seus objetivos desejados.

Para Wooldridge \& Jennings (2003), flexibilidade significa:

a) reatividade: agentes inteligentes são capazes de perceber seu ambiente, responder com um comportamento adequado à situação e fazer intervenções em tempo necessário para 
que satisfaçam seus objetivos definidos;

b) proatividade: agentes inteligentes são capazes de dirigir-se a uma meta tendo a iniciativa de satisfazer a seus objetivos definidos;

c) habilidade social: agentes inteligentes são capazes de interagir com outros agentes (e possivelmente humanos) em ordem de satisfazer a seus objetivos definidos.

Ainda para o autor, para sistemas não funcionais, este modelo simples de programação direta orientada para objetivos não é aceitável, já que ele considera hipóteses bem limitadas. Em particular, ele assume que o ambiente não se altera enquanto o procedimento está sendo executado. Se o ambiente realmente se altera e, em particular, se as hipóteses (pré-condições) que estão por trás do procedimento se tornam falsas enquanto o procedimento é executado, então o comportamento do procedimento pode não ser definido — freqüentemente ele entrará em falência (crash). É também assumido que o objetivo, isto é, a razão para executar o procedimento, permaneça válida até, no mínimo, o procedimento terminar. Se o objetivo não se mantém válido, não existe razão para continuar a execução do procedimento.

Para Russel \& Norvig (2003), os agentes devem sempre se sujeitar ao ambiente em que vão executar suas ações e dependem dessas propriedades para o sucesso ou fracasso na operação. As propriedades do ambiente em que o agente atuará dividem-se em:

a) Totalmente observável versus parcialmente observável: se os sensores do ambiente dão acesso completo do estado do ambiente ao agente em tempo integral, então dizemos que o ambiente onde os agentes vão executar tarefas é completamente observável. Um ambiente totalmente observável é conveniente dado que o agente não precisa manter nenhum controle do seu estado interno.

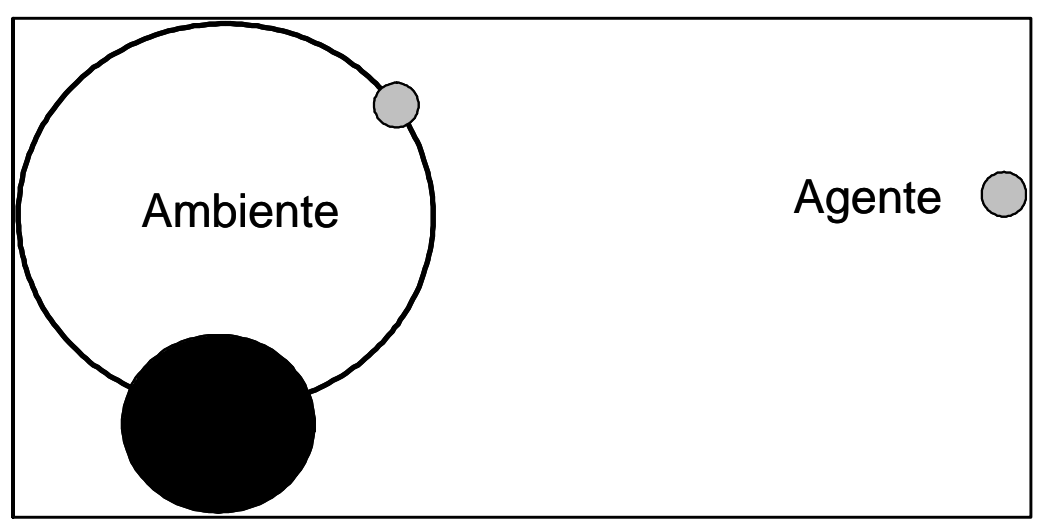

\section{Ilustração 15 - Ambiente parcialmente observável.}


b) Determinístico versus probabilístico: se o próximo estado do ambiente é completamente determinado pelo estado atual e/ou também pela ação executada pelo agente, então dizemos que o ambiente é determinístico; do contrário, ele é estocástico.

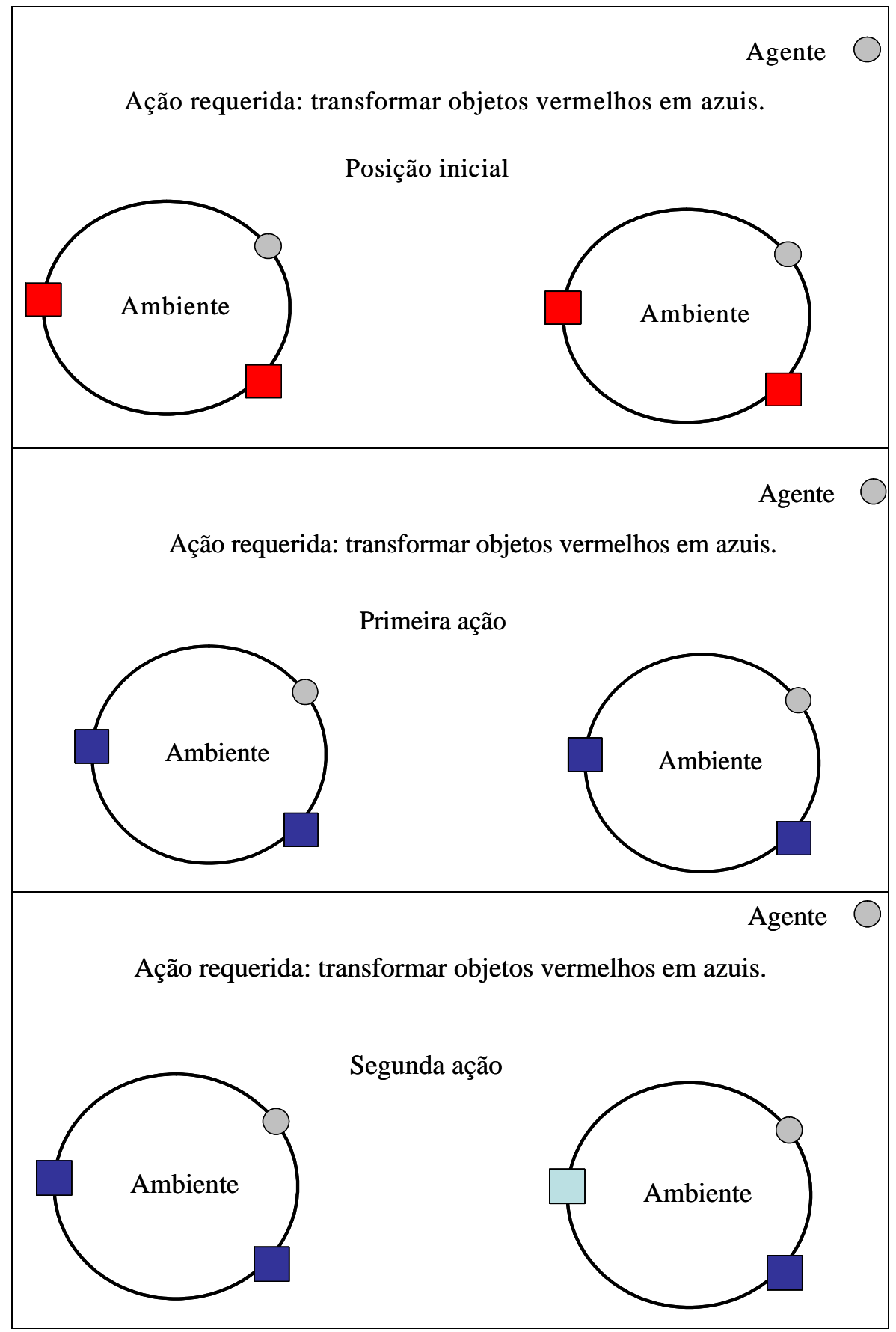

Ilustração 16 - Ambiente determinístico versus probabilístico. 
c) Episódico versus seqüencial: em um ambiente de tarefas episódico, a experiência de um agente é dividida em episódios atômicos. Cada episódio consiste em um agente percebendo e, então, executando uma simples ação. Um próximo episódio não depende das ações que aconteceram em episódios anteriores. Em ambientes episódicos, a chance de ação em cada episódio depende somente dele mesmo. Ambientes episódicos são mais simples que ambientes seqüenciais porque o agente não precisa se antecipar na decisão.

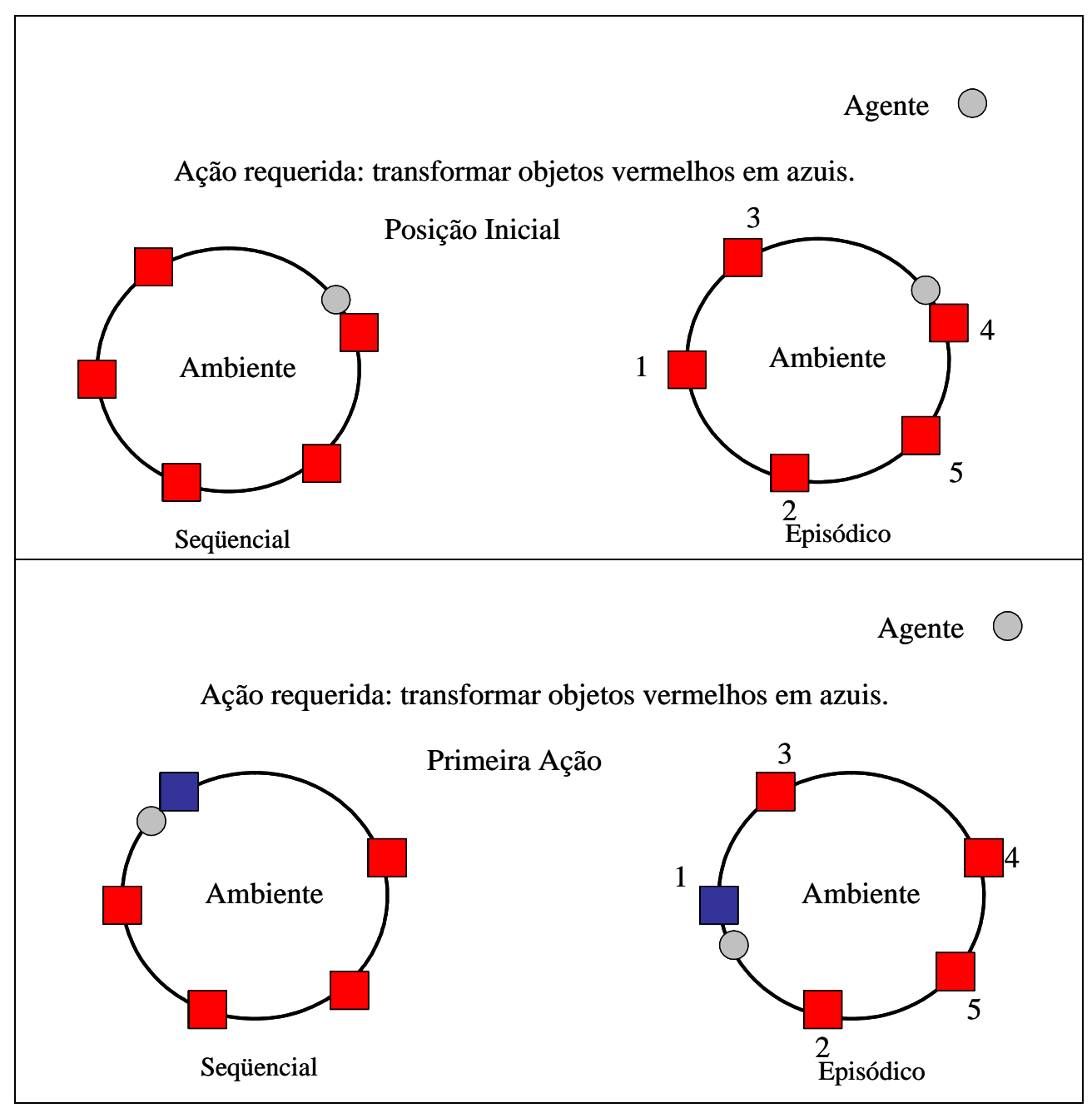

Ilustração 17 - Ambiente episódico versus seqüencial. 
d) Estático versus dinâmico: se o ambiente pode mudar enquanto o agente está funcionando, então dizemos que ele é dinâmico para esse agente. Do contrário, ele é estático, muito mais fácil de lidar, pois o agente não necessita ficar vigiando o ambiente todo o tempo enquanto está decidindo sobre uma ação a ser tomada, nem se preocupar com a passagem do tempo. Ambientes dinâmicos, por outro lado, estão continuamente questionando ao agente o que ele deseja fazer.

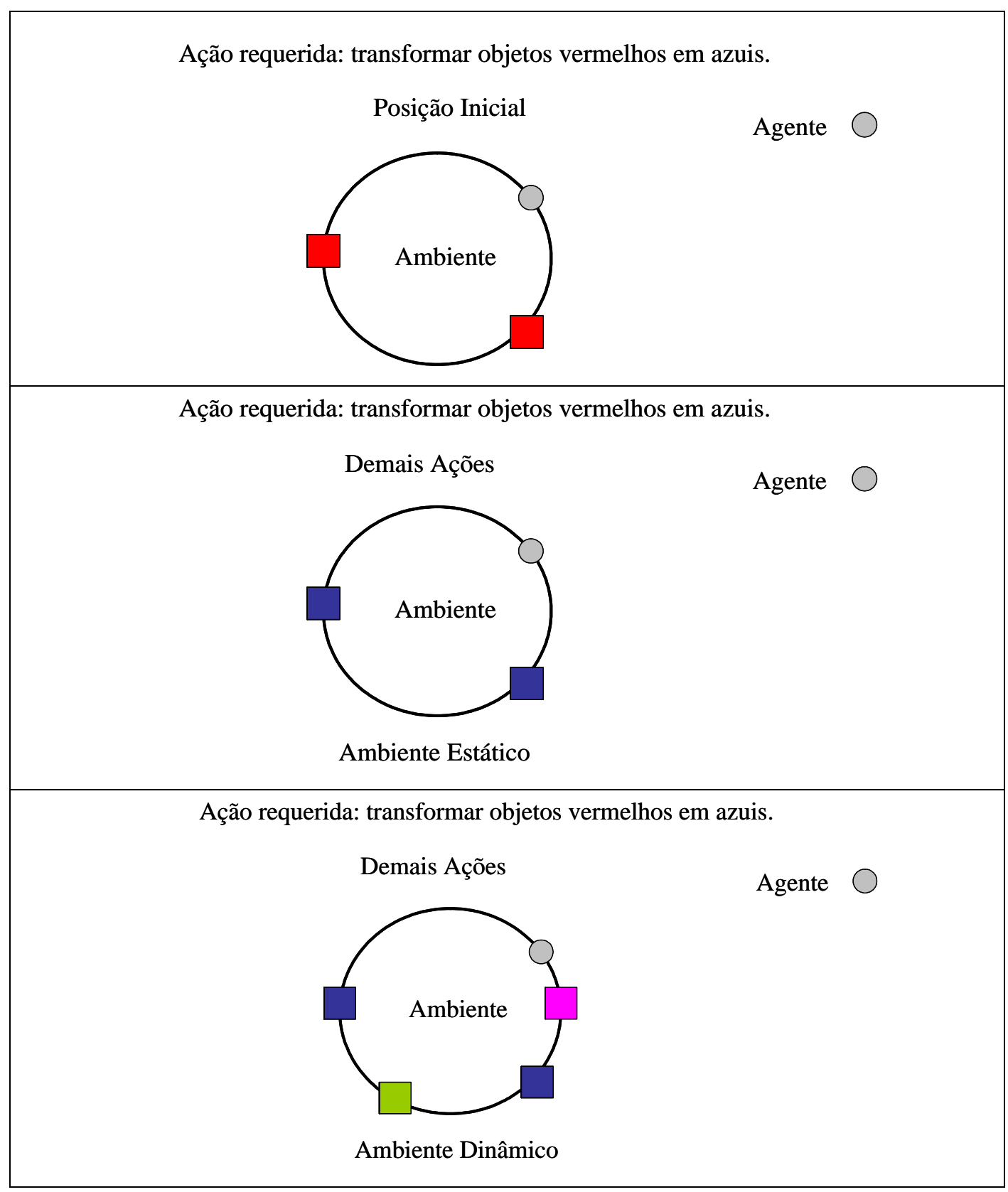

Ilustração 18- Ambiente estático versus dinâmico. 
e) Discreto versus contínuo: a distinção entre discreto e contínuo pode ser aplicada ao estado do ambiente, à forma como o tempo é manejado e às percepções e ações do agente.

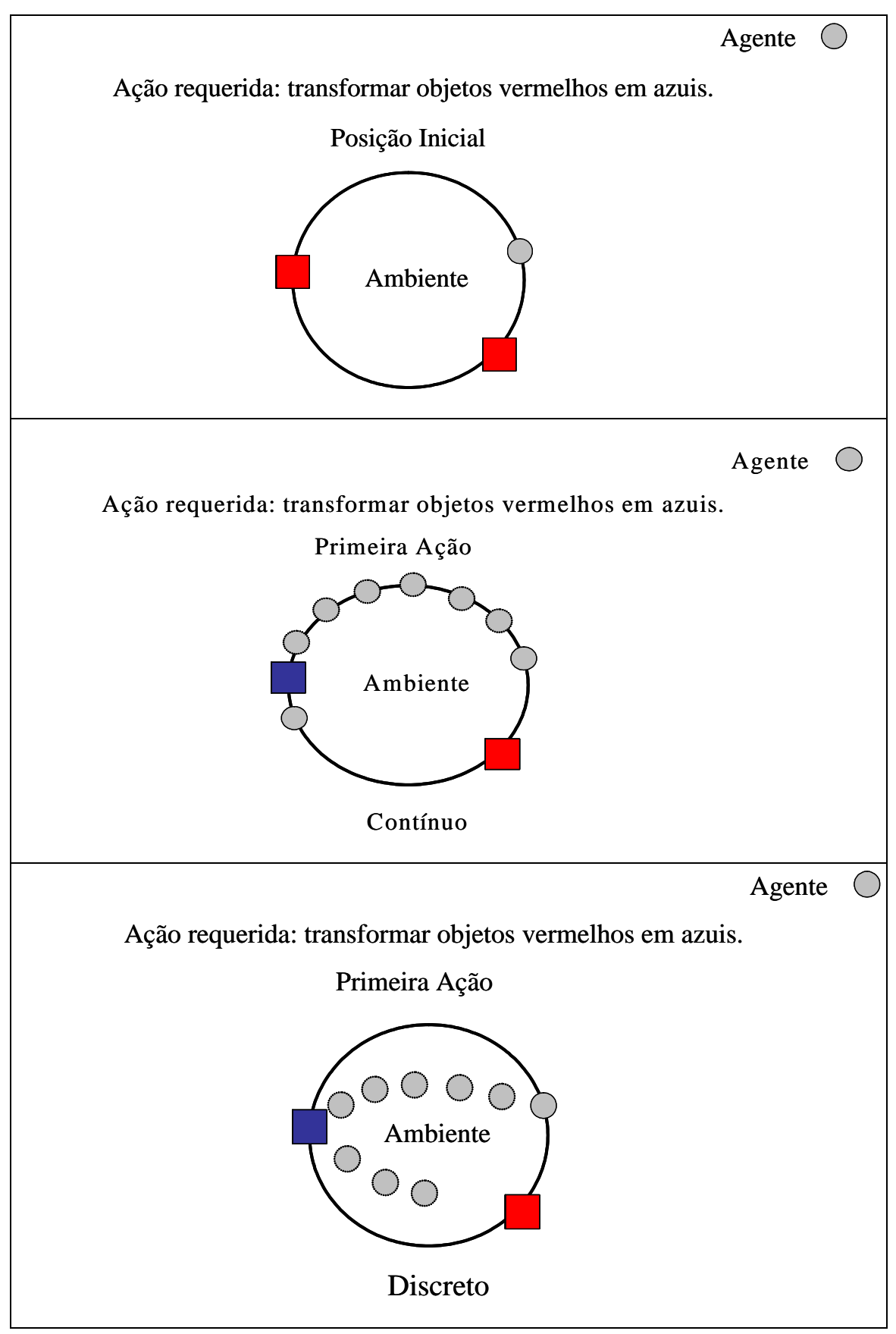

Ilustração 19 - Ambiente discreto versus contínuo. 
f) Ambiente com múltiplos agentes: o autor utiliza um exemplo, que diz ser muito fácil de entender: "um agente resolvendo uma palavra-cruzada por si mesmo é claramente um ambiente com agente simples, mas um agente jogando xadrez está em um ambiente com dois agentes".

Em suma, as classes de ambientes de maior complexidade em que agentes podem agir são as inacessíveis, não determinísticas, dinâmicas e contínuas. Ambientes que têm essas propriedades são freqüentemente denominados abertos (HEWIT, 1986 apud WOOLDRIDGE, 2002). Além da construção de agentes, de programas que excutam ações, é fundamental que se leve em consideração esses estados do ambiente para que estes agentes possam agir de forma a atingir seus objetivos.

\subsubsection{Como trabalham os mecanismos de pesquisa}

Os mecanismos de busca trabalham armazenando informação sobre um grande número de

páginas Web. Essas páginas são recuperadas por um programa tipo Web Crawler, um programa ou um script automatizado que percorre a World Wide Web de uma forma metódica, automatizada (chamada algumas vezes de Web Spider ou Web Robot). Um Web Browser automatizado, que segue cada link que encontra, excluindo aqueles que usam robots.txt. O conteúdo de cada página é analisado para saber como deverá ser indexado e armazenado em um banco de dados para ser utilizado futuramente através de queries com palavras-chave.

Quando um usuário deseja pesquisar por meio de um mecanismo de busca através de uma query, tipicamente através de palavras-chave, o mecanismo busca nos índices e provê uma lista das páginas da Web de acordo com o critério requisitado. Vários mecanismos suportam operadores booleanos como AND, OR e NOT. Na verdade, as pesquisas mais atuais estão sobre mecanismos que trabalham com pesquisas por similaridade, utilizando teorias de clustering (agrupamento), redes neurais e teoria bayseana.

Chen et al, (2002, apud DECKER 2005) cita que Chen e sua equipe desenvolveram uma ferramenta para pesquisa e disponibilização de informação disponível na Internet baseada em tecnologia de agentes inteligentes, denominada CI Spider. Essa ferramenta requisita ao usuário uma URL (endereço de um site de interesse) inicial e palavras-chave a serem 
utilizadas para avaliar os links e documentos que são encontrados no sistema e exibidos em um gráfico bidimensional.

\subsection{Um estudo de caso de Inteligência Competitiva utilizando agentes inteligentes, segundo Lafaye (2005)}

Lafaye (2005) elabora dois estudos de caso que objetivam responder à problemática acerca dos tipos de dinâmicas organizacionais capazes de assimilar a tecnologia de agentes inteligentes num processo de rastreamento de sinais fracos.

No processo de monitoramento estratégico, a atividade de aquisição das informações de caráter estratégico (fase de rastreamento) incorpora cada vez mais a Internet como uma fonte escolhida. No entanto, essa mídia, no exercício do monitoramento prospectivo, caracteriza-se por complexidade e grandes dificuldades, sendo o excesso de informação sua principal causa.

Segundo o autor, é por esse motivo que os agentes inteligentes de monitoramento estratégico — definidos como ferramentas autônomas e automatizadas de ajuda na coleta de informações — são colocados à disposição dos rastreadores. Em virtude da predileção dos técnicos pelo investimento nessas tecnologias e do reduzido número de trabalhos de gestão abordando esses instrumentos, o trabalho de Lafaye buscou responder a essa problemática apoiado na análise qualitativa de dois estudos de caso.

Organizações são sistemas sociais abertos, voltados para um ambiente externo, submetidos a restrições significativas de mudanças e incertezas. As empresas têm necessidade de utilizar o recurso informacional externo de maneira dinâmica, estruturada, coletiva e estratégica (vantagem competitiva que garante a sua continuidade, sendo esta a função do monitoramento estratégico). Choo (1995 apud LIU, 1998) reafirma que as organizações se comportam como sistemas complexos e abertos e estão engajadas ativamente em trocar informações como entrada e saída de controles com o ambiente.

Lafaye (1995), para o modelo conceitual inicial, apóia-se na teoria geral de sistemas de informação desenvolvida por Alter (1996, 1999), abaixo representada, adaptando o "conceito de trabalho" ao contexto do monitoramento estratégico, particularmente na fase de busca (rastreamento) de informação, obtendo o modelo da Ilustração 20. 


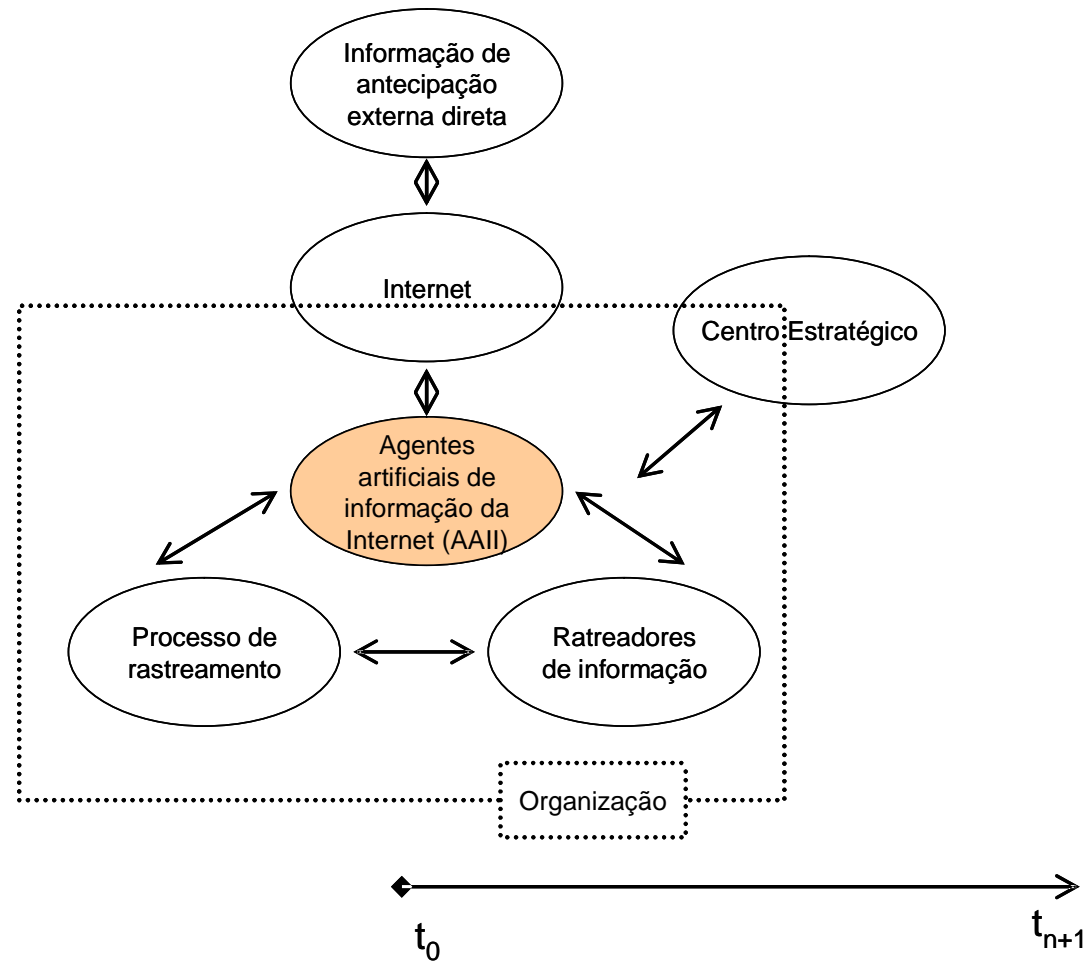

Ilustração 20 - Esquema conceitual.

Fonte: Lafaye (2005).

Distintamente do modelo alteriano, que utiliza a denominação "cliente", o autor utiliza a de “centro estratégico", conceito de Martinet (1984). Se o centro estratégico está situado dentro ou fora da organização é porque pode espelhar duas realidades distintas.

Lafaye (2005), tal como no presente trabalho, restringe-se à aplicação de agentes inteligentes na fase de aquisição, ou fase de rastreamento da informação.

Normalmente, as informações antecipativas são coletadas pelos rastreadores em seu deslocamento, encontros e comunicações fora da empresa. Em contrapartida, a Internet coloca-se como um novo terreno de rastreamento, porém de alta dificuldade em caso de exercício manual. Lafaye (2005) propôs o uso de agentes inteligentes - concebidos como entidades programadas autônomas, automatizadas e teoricamente dotadas de capacidades de inferência. 
onde o papel é, a partir de diferentes fontes distribuídas, de facilitar a identificação, a recuperação, a seleção e o acesso de informação considerada como pertinente pelo usuário. Optamos pelos agentes de busca (permitem ao usuário desobrigar-se da tarefa de identificação, de extração e, em parte, de filtragem de dados correspondentes a uma solicitação definida) e agentes de vigilância ( propõem-se a avisar o usuário toda vez que um objeto Internet visado sofre uma modificação).

Lafaye (2005) criou e acompanhou os casos estudados nas organizações Sierra (entrevistas por telefone, após a utilização da ferramenta criada e implementada na organização) e Tango (entrevistas semidiretas do tipo face a face).

A Organização Sierra: grande laboratório industrial de materiais cuja missão principal é efetuar pesquisas e monitoramento do ambiente científico, técnico e tecnológico, para as filiais industriais do grupo Delta (indústria de transformação de matérias-primas). O departamento em que as entrevistas foram feitas foi o de serviços em fontes de documentação e monitoramento, com dois encarregados de rastreamento, pesquisadores e engenheiros dos centros de pesquisa e desenvolvimento ou das fábricas localizadas no mundo inteiro. Os rastreadores têm um AAII de pesquisa e monitoramento do tipo servidor multipostos.

Concluindo o caso Sierra, pode-se dizer que a apropriação da tecnologia AAII segue uma trajetória na qual o foco está na questão técnica da ferramenta. De fato, com a introdução da tecnologia AAII, a atividade de rastreamento deve, inicialmente, centrar-se na ferramenta a fim de liberar os recursos humanos para o desenvolvimento do campo de rastreamento. A questão é que existem problemas como: a ferramenta desenvolvida evolui com velocidade menor que a Internet, surgindo novos formatos Web (plugin, pdf, flux, RSS, Xml etc.), sem que o programa possa integrá-los nas adequações de parâmetros de rastreamento. A Sierra teve que chamar um consultor para resolver problemas como estes. Em outras palavras, a organização não atingiu uma autonomia estrutural de funcionamento com o AAII.

A falta de maturidade da ferramenta foi um gerador de problemas crítico. A performance de rastreamento automatizado, assim como seu desenvolvimento, é condicionada pelas atualizações regulares do AAII. Em virtude desses problemas recorrentes, as estratégias e os modos de rastreamento propostos foram limitados. Os rastreadores conservaram ativos os procedimentos manuais de rastreamento.

A Organização Tango: é uma associação pública criada em 1986 e que evoluiu rapidamente para uma rede de documentação nacional. Sua missão é disponibilizar, para os profissionais e para o público, informações especializadas sobre assuntos societários. O local das entrevistas foi o centro coordenador de Lyon que possui sete funcionários, três deles rastreadores (um 
voluntário e dois designados, utilizadores do AAII de vigilância monoposto).

Resultados do estudo na Tango: a tecnologia Internet chega à empresa através do estudo de caso, com os objetivos de alimentar uma base de dados interna para permitir a todo o centro responder às solicitações dos usuários e, enfim, elaborar as vigilâncias temáticas. O modo de funcionamento do trabalho se desorganiza e desestrutura rapidamente. Todo membro da empresa se vê diante de uma massa de informação à qual não tinha acesso antes.

A escolha de recorrer à tecnologia AAII é analisada em dois níveis diferentes:

a) de macrocontexto: focalizado na entidade global da empresa. $\mathrm{O}$ objetivo inicial vem de uma vontade de estruturar a rede de vigilância;

b) de microcontexto: focalizado no centro coordenador da empresa (aumentar a capacidade reativa dos rastreadores em função da solicitação, estender o campo de fontes a vigiar e mostrar a via da modernização aos outros membros da empresa).

Antes da introdução da ferramenta de AAII, o processo de rastreamento era definido, pelos atores locais, como lento, repetitivo e primário.

Após a sua implementação, eles ressaltam que uma parametrização adequada da ferramenta necessita de uma análise detalhada e da compreensão da sua estrutura no seu modo de funcionamento.

Na fase de iniciação as questões são:

[...] o problema é que existe uma diferença fundamental entre o rastreamento manual na Internet e o rastreamento automático: no primeiro caso um conhecimento básico da estrutura do site é suficiente para operacionalizar o rastreamento, enquanto no segundo, um conhecimento mais preciso e mais técnico da arquitetura e do modo de funcionamento do site são necessários para sua implementação e sua delegação à ferramenta [...]

[...] durante a fase de iniciação, o aprendizado necessário para a assimilação do AAII constituiu uma barreira importante para sua utilização. (LAFAYE, 2005).

$\mathrm{Na}$ fase de expansão, o maior problema esteve em um desenvolvimento limitado pelas competências técnicas dos atores. Como resultado, os usuários do centro utilizam a ferramenta de forma básica. Paradoxalmente, segundo o responsável pelo serviço, apesar da ferramenta não permitir o benefício da economia de tempo, nem atingir seus objetivos iniciais, sua utilização é considerada indispensável. 
$\mathrm{O}$ autor altera parcialmente o modelo inicialmente proposto, por achar fundamental a colaboração e a estrutura de Tecnologia da Informação, prestadores de serviço de vigilância externos à organização, entidades externas de visão organizadora para darem suporte à implementação.

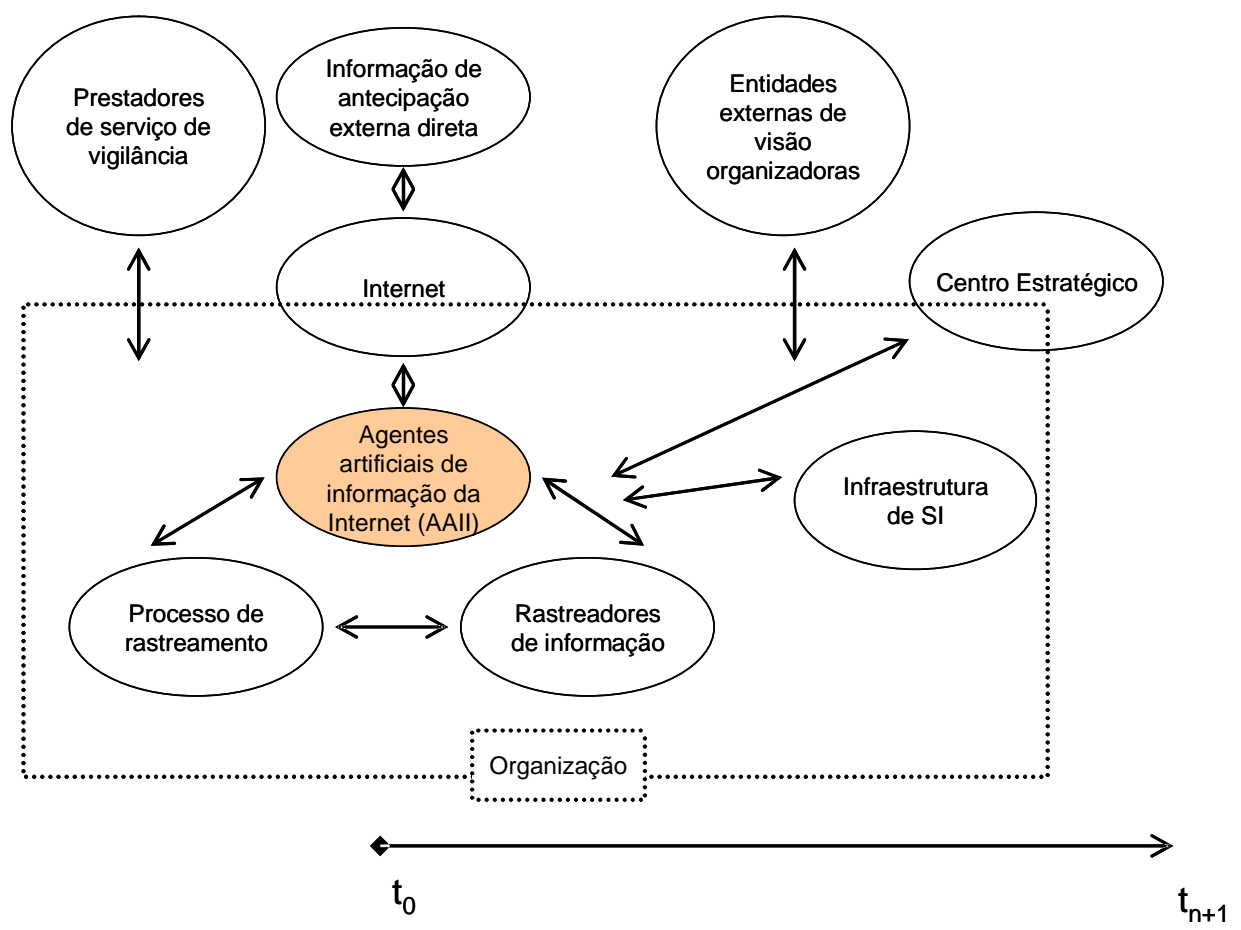

Ilustração 21 - O modelo conceitual final.

Fonte: Lafaye (2005, p.21).

Conclusão do estudo de caso de Lafaye (2005):

a) O caso da Sierra mostrou que a atualização e a estabilidade da ferramenta são fundamentais.

b) $\mathrm{O}$ caso Tango demonstrou que o treinamento inicial dos rastreadores pode reduzir a chance de resultado lento ou mesmo negativo na implementação de um agente Internet baseado em agentes inteligentes. 


\section{METODOLOGIA DE PESQUISA}

Esta pesquisa foi desenvolvida através de um método do tipo pesquisa-engenharia (referência), que é a construção e aplicação de uma ferramenta e, conseqüentemente, a análise dos resultados obtidos com essa aplicação.

Nesse sentido, ela foi desenvolvida a partir da construção e aplicação de um protótipo de software de busca na Internet baseado em conceitos de agentes inteligentes.

\subsection{Aspectos básicos da pesquisa}

A pesquisa é calcada em três aspectos básicos:

a) Desenvolvimento e aplicação de uma ferramenta de busca na Internet:

Apesar da existência de ferramentas de busca prontas na Internet, tais como Google, Yahoo, Exalead, CIspider (Competitive Intelligence Spider), crawlers em geral, um protótipo de uma ferramenta de busca foi criado nesta pesquisa com o objetivo de permitir ao pesquisador avaliar uma maior independência e autonomia na definição de parâmetros para o software. Permitiu também avaliar as necessidades e dificuldades de escolher parâmetros e efetuar a busca na Internet; de melhor conhecer a estrutura dos sites, para assim melhor focar a pesquisa nestes. Uma vez que o objetivo principal da pesquisa não foi o de gerar uma ferramenta de alto desempenho na busca de informações na Internet, mas sim testar a possibilidade de encontrar sinais antecipativos através da Internet e com o auxílio destas ferramentas, utilizou-se também a ferramenta de busca do Google para fins comparativos. Dessa forma, foi possível avaliar e interpretar os resultados obtidos com as duas ferramentas.

b) Uma abordagem de busca de sinais antecipativos (sinais fracos):

Foi utilizada a abordagem proposta por Lesca (2003) para estabelecer o foco de busca dos sinais antecipativos, isto é, estabelecer o que ele denomina atores, temas e fontes de informação, que configuram assim o foco de busca ou, de maneira mais abrangente, de monitoramento. $\mathrm{O}$ estabelecimento do foco norteou o estabelecimento dos critérios de busca através do protótipo de busca, bem como do Google.

c) A interação do pesquisador com as ferramentas de software e a abordagem proposta por Lesca (2003):

Um terceiro aspecto relevante diz respeito ao papel do pesquisador, que tanto construiu 
a ferramenta, efetuou sua implementação, obtendo as informações da Internet, quanto analisou as informações obtidas. Uma vez que o processo de monitoramento estratégico antecipativo significa um processo de inteligência através da interpretação de sinais antecipativos, a ferramenta utilizada é apenas parte inicial do processo de inteligência, buscando facilitar sua identificação. No entanto, cabe ao pesquisador efetuar a interpretação dos sinais obtidos. A questão relevante foi então verificar até que ponto o mecanismo de busca facilita ou enriquece o processo de monitoramento estratégico através de um acesso automático, e eventualmente mais eficaz, de busca de sinais antecipativos. É importante lembrar que as informações obtidas foram baseadas na busca de sinais em fontes de informações formais. Dentro do processo de monitoramento estratégico, as fontes podem ser classificadas em fontes formais e informais (LAFAYE, 2005).

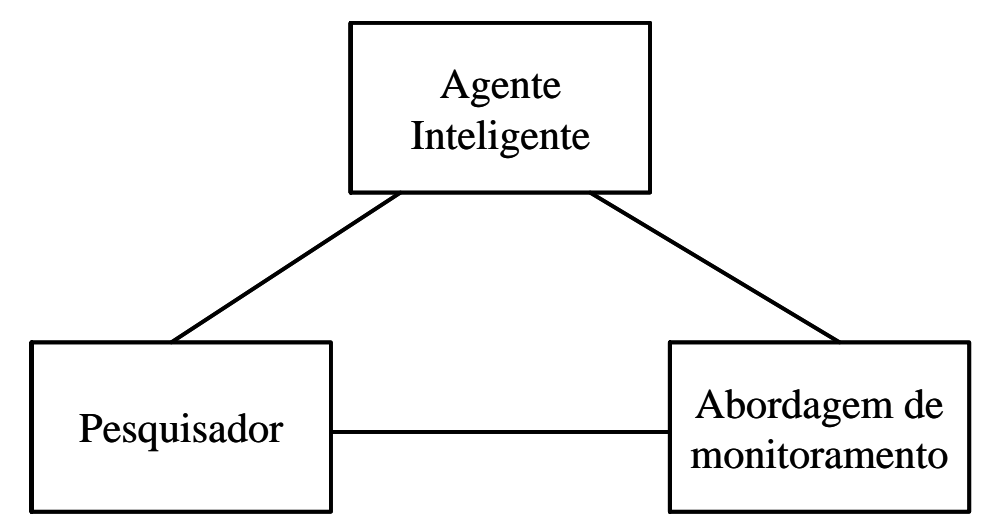

\section{Ilustração 22 - Modelo para solução de monitoramento estratégico envolvendo abordagem do monitoramento, pesquisador e agente inteligente.}

\subsection{Etapas da pesquisa:}

A pesquisa foi desenvolvida seguindo as etapas:

a) Desenvolvimento e aplicação de uma ferramenta de busca na Internet:

O software desenvolvido apoiou-se na utilização de códigos disponíveis na literatura e em sites especializados em códigos Java de utilização livre.

b) Estabelecimento do foco de monitoramento:

Foco de monitoramento: a fim de testar o conceito proposto, foi necessário estabelecer um foco de monitoramento que pudesse ser tratado nesta pesquisa. 
O estabelecimento de um foco no MAE-IC é a operação pela qual se delimita o ambiente externo à empresa em que há o interesse comum dos membros do grupo. Construir um foco de MAE-IC significa exprimir, de modo explícito e formal, o objeto de interesse do monitoramento.

Foi escolhido então o setor de redes de supermercados, em razão de sua dinâmica atual no Brasil e de sua exposição na mídia.

Atores: Foram escolhidas redes de supermercado a serem monitoradas. Atores podem ser pessoas físicas ou jurídicas, externas às fronteiras do monitoramento estratégico, cujas decisões e ações podem exercer influência direta ou indireta no futuro da organização. Estes atores devem ser nomeados, identificados e caracterizados. Termos genéricos como "mercado" ou "a concorrência" não são especificações de ator (LESCA, 2003).

Temas: Dada à dinâmica do setor, foram escolhidos temas ligados a processos de expansão, fusões e aquisições dessas redes. Um tema é o centro de interesse que pode influenciar o futuro, podendo ser identificado de diversas formas (LESCA, 2003):

- Em relação a um ator específico;

- Em relação a vários atores simultaneamente;

- Sem referência a nenhum ator em particular. Por exemplo, quando os atores não são conhecidos, mas potenciais.

Fontes: Uma vez que o objetivo era pesquisar informações na Internet, um conjunto de sites foi selecionado, conjunto este que pudesse fornecer os sinais procurados.

c) Busca dos sinais antecipativos na Internet:

Uma vez desenvolvidas as primeiras versões do software, foi iniciado o processo de busca e obtenção de informações. A partir dos resultados obtidos, o software evoluiu e foi adaptado a fim de melhorar sua adequação às necessidades de informação.

A abordagem de busca na Internet por intermédio de um agente desenvolve-se através de duas etapas. Uma primeira etapa, de indexação dos sites buscados, que faz com que haja uma transformação de arquivos em vários formatos em um único formato tratável posteriormente. Na segunda etapa ocorre então a busca através de palavras-chave 
(atores e temas estabelecidos no alvo de monitoramento) e operadores booleanos.

d) Análise e interpretação das informações obtidas:

Uma vez obtidas as informações, voltou-se então à aplicação dos conceitos da abordagem proposta por Lesca (2003) de interpretação das informações obtidas à busca de identificação de sinais antecipativos, formados freqüentemente como um conjunto de informações obtidas. 


\subsection{Modelo da pesquisa}

O modelo de pesquisa empregado pode então ser representado a partir da Ilustração 23:

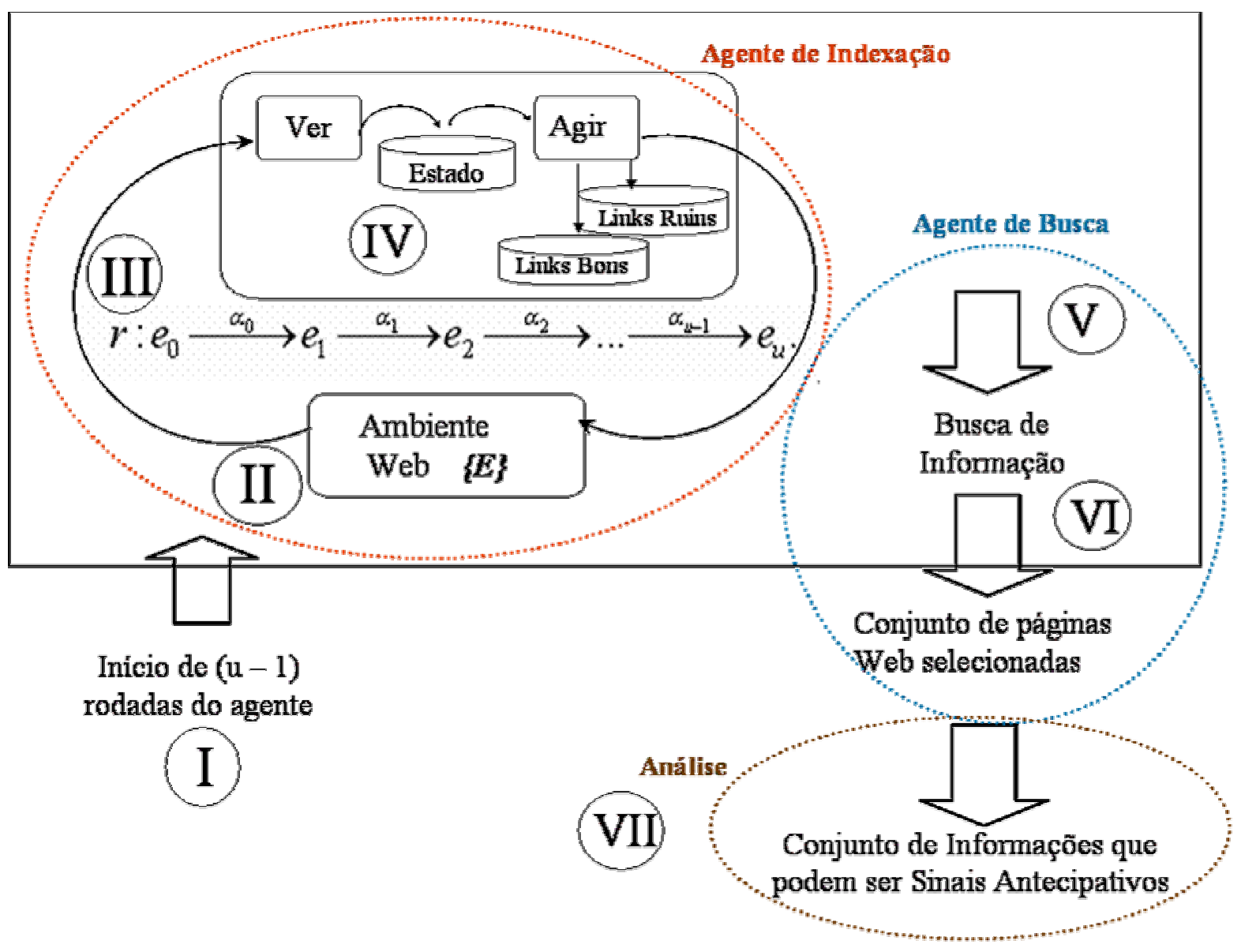

Ilustração 23 - Modelo de pesquisa proposto.

Para explicar em maior detalhe o modelo de pesquisa a ser aplicado exibido, na Ilustração 23, cada algarismo romano representa uma etapa do processo geral:

I. Inicia-se uma série de (u-1) iterações de busca na Web por links bons (aqueles que permitem acesso e que não representem perigo para o ambiente);

II. São executadas "u-1" pesquisas no ambiente Web, representadas pelo conjunto de estados do ambiente $\{\boldsymbol{E}\}$ onde se encontra os tipos mais difíceis de estados a serem tratados: parcialmente observável (se sensores do ambiente não dão acesso completo do 
estado do ambiente ao agente em tempo integral então dizemos que o ambiente onde os agentes vão executar tarefas não é completamente observável), probabilístico (se o próximo estado do ambiente é completamente determinado pelo estado atual e/ou também pela ação executada pelo agente, então nós dizemos que o ambiente é determinístico; do contrário ele é probabilístico), episódico (cada episódio consiste de um agente percebendo e executando uma simples ação; um próximo episódio não depende das ações que aconteceram em episódios anteriores), dinâmico (se o ambiente pode mudar enquanto o agente está funcionando então nós dizemos que o ambiente é dinâmico para este agente) e contínuo (a distinção entre discreto e contínuo pode ser aplicada ao estado do ambiente, a forma em que o tempo é manejado e às percepções e ações do agente).

III. Cada rodada de um Agente "r", aqui representando genericamente, no ambiente Web encontra um estado $\left(\mathrm{e}_{0}, \mathrm{e}_{1}, \mathrm{e}_{2}, \ldots\right)$ que é seguido por uma ação interposta correspondente $\left(\alpha_{0}, \alpha_{1}, \alpha_{2}, \ldots\right)$, como verificar se já existe um repositório de links visitados e bons ou links visitados ruins, criá-los em caso negativo e em caso positivo, gravar um link bom para futura pesquisa de interesse em atores e temas escolhidos ou gravar um link ou endereço de página ruim, que não será utilizado futuramente. A cada rodada, o agente de Indexação verifica se o link encontrado no ambiente já foi visitado anteriormente, para que a pesquisa não se torne infinita;

IV. O agente denominado de Indexação, agora como uma agência, é composto pelos agentes Ver (verifica qual o estado em que o ambiente se encontra), que passa uma mensagem para Ação, que armazena a informação em repositório de links bons, indexando-as para serem lidas posteriormente, ou em repositório de links ruins, a serem desprezados.

V. O agente denominado Busca requisita uma query com palavras chave a serem rastreadas no repositório de links bons, que designam os temas e atores especificados anteriormente, e a partir do endereço (URL) de uma fonte escolhida, busca páginas que tratam do tema e atores desejados;

VI. O produto do processo (V) é um conjunto de páginas WEB selecionadas que obedecem ao objetivo especificado através de Temas, Atores e Fonte. 
VII. A análise é executada a cada endereço de página WEB (URL) encontrada, manualmente pelo pesquisador, verificando se a informação contida na página encontrada pode ser proveitosa para a formação de sinais antecipativos. 


\section{PESQUISA}

\subsection{Desenvolvimento e aplicação de uma ferramenta de busca na Internet}

Para o desenvolvimento do agente Indexação do ambiente Web, foi utilizado como ferramenta, a partir da qual foi escrito o programa de indexação do protótipo, um código baseado no que se encontra detalhado em artigo de Heaton (2002), autor do programa, que utiliza o conceito de spider, também chamado crawler, para a construção de um indexador da Web:

Spiders são programas que podem visitar sites da WEB e seguir hyperlinks. Usando um spider você pode rapidamente mapear as páginas contidas em um site da WEB [...] Java é particularmente uma boa escolha como uma linguagem para construção de spiders. Java suporta o protocolo http, que é utilizado para transferir a maior parte de informações da WEB. (HEATON, 2002)

Em artigo de 2005, Mostafa diz que muito do conteúdo digital hoje permanece inacessível devido ao fato de muitos sistemas não armazenarem na Web formatos que usuários normalmente conseguem ver. Os programas típicos de spiders ou crawlers sofrem com estes problemas, impedidos de recuperar este conteúdo, denominado hidden Web (Web escondida), estimado segundo o autor em 500 vezes o tamanho da web convencional.

O protótipo de indexação construído é tipicamente um crawler, como os que se baseiam os grandes mecanismos de busca do mercado.

Um segundo programa, que compõe o protótipo, denominado ProcurarIndex.java foi uma adaptação da biblioteca Apache Lucene, um projeto de código aberto para pesquisa de texto, escrito na linguagem Java, de utilização gratuita.

\subsection{Estabelecimento do foco de monitoramento}

$\mathrm{O}$ foco de monitoramento escolhido o setor de redes supermercadista. Como observado anteriormente, optou-se por este foco por ser um setor bastante dinâmico, objeto de grande movimentação das empresas atuantes. Conforme a abordagem adotada (LESCA, 2003), os seguintes itens compuseram o foco:

a) Atores:

Uma vez que Lesca (2003) sugere um número limitado e administrável de atores a 
serem escolhidos, os atores adotados para serem monitorados nesta pesquisa foram as três maiores redes de supermercados do Brasil, segundo o Ranking da Abras (SuperHiper, 2006):

- Companhia Brasileira de Distribuição, CBD (Grupo Pão de Açúcar);

- Carrefour; e

- Wal-Mart;

b) Temas:

A fim de restringir o processo de monitoramento, alguns temas foram escolhidos por sua relevância e presença na mídia:

- fusão (ou joint-venture);

- aquisição;

- compra e venda de bandeiras de redes nacionais ou internacionais;

c) Fontes de informação a pesquisar:

Uma vez que o objeto de estudo envolve a pesquisa de informações na Internet, foram selecionados sites da grande mídia e sites específicos do setor supermercadista.

- O Estado de São Paulo (iwww.estadao.com.b̆bi);

- A Folha de São Paulo (http://www1.folha.uol.com.br);

- Valor Econômico (hîttp:///www.valoronline.com.bìn),

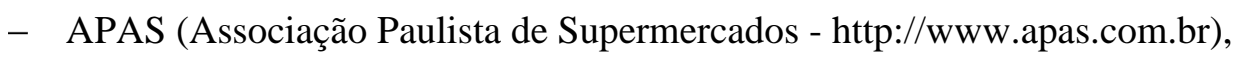

- ABRAS no site AbrasNet (Associação Brasileira de Supermercado com sua respectiva publicação SuperHiper - hittp://Www.abrasnet.com.bịt) e

- PROVAR (Programa de Administração de Varejo - http:/ /Wwww.provar.org).

\subsection{Busca dos sinais antecipativos na WEB}

Segundo o modelo exibido anteriormente na Ilustração 23, a primeira fase da ação se dá com a execução do agente Indexação de cada uma das fontes citadas no item 5.2, utilizando-se o protótipo desenvolvido em Java. Este protótipo foi adaptado a partir de um programa de acesso livre com código descrito ajustado às necessidades da pesquisa, denominado checkLinks.java, cujas telas se encontram nas Ilustrações 24 e 25.

Inicia-se o procedimento de indexação dos sites conforme a tela exibida na Ilustração 24. Para 
cada uma das fontes identificadas no item 5.2, é requisitada a URL raiz do site que se pretende visitar. A partir do site especificado, o programa segue e indexa todas as páginas que têm algum link a partir da página inicial e, a partir desta página chamada, o programa busca páginas citadas nesta, e assim por diante, conforme Ilustração 25. Se essa busca fosse feita sem nenhum controle de repetição, ela seria infinita.

Portanto, as páginas são armazenadas em um repositório, páginas que ainda não estejam identificadas por indexação anterior, para que sejam utilizadas em momentos de busca posteriores. A quantidade de páginas indexadas não obedece a uma relação direta com a quantidade de informação disponibilizada pelo site em questão, mas com a qualidade da construção desse site, que muitas vezes mantém um sistema de identificação de links com nomes diferentes e fixos para retornos à mesma página.

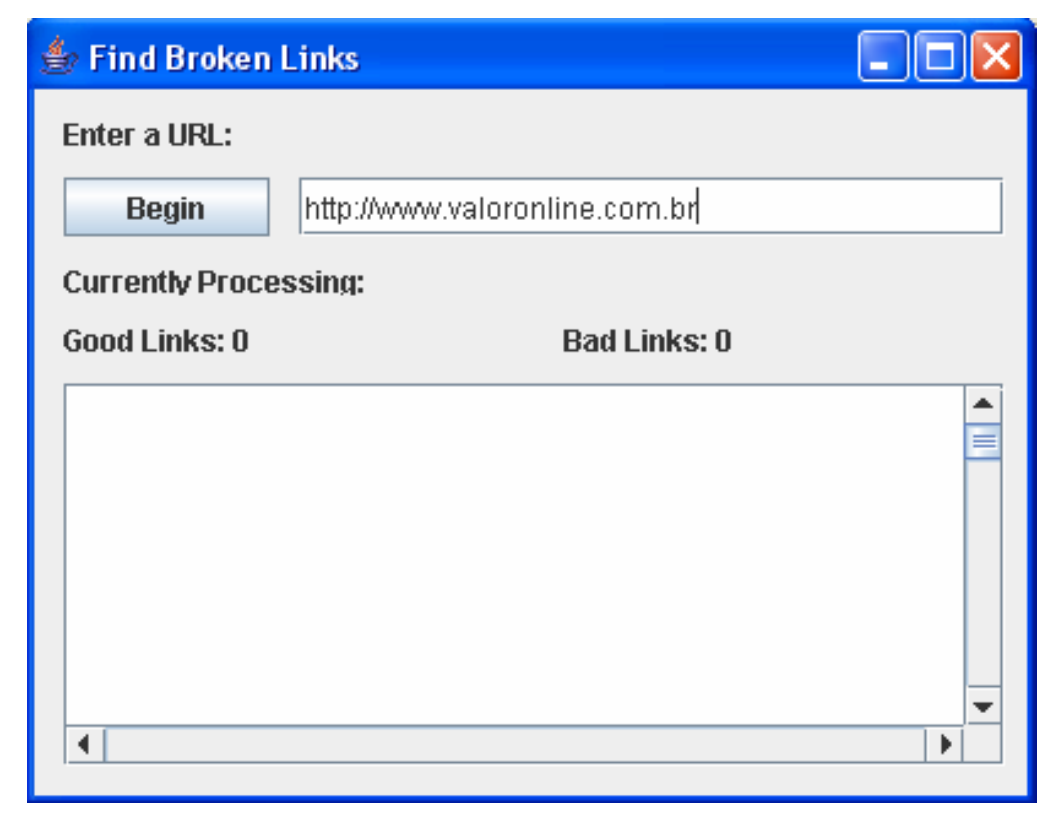

\section{Ilustração 24 - Tela inicial do programa de indexação da Web.}

$\mathrm{Na}$ tela representada na Ilustração 25, o programa foi interrompido logo após o seu início apenas a título de exemplo. Essa tela exibe a quantidade de links aproveitados (good links:27) e de links que possuem um bloqueio de acesso (bad links: 1) e que não podem ser indexados. Os bad links aparecem listados no quadro inferior da figura. 


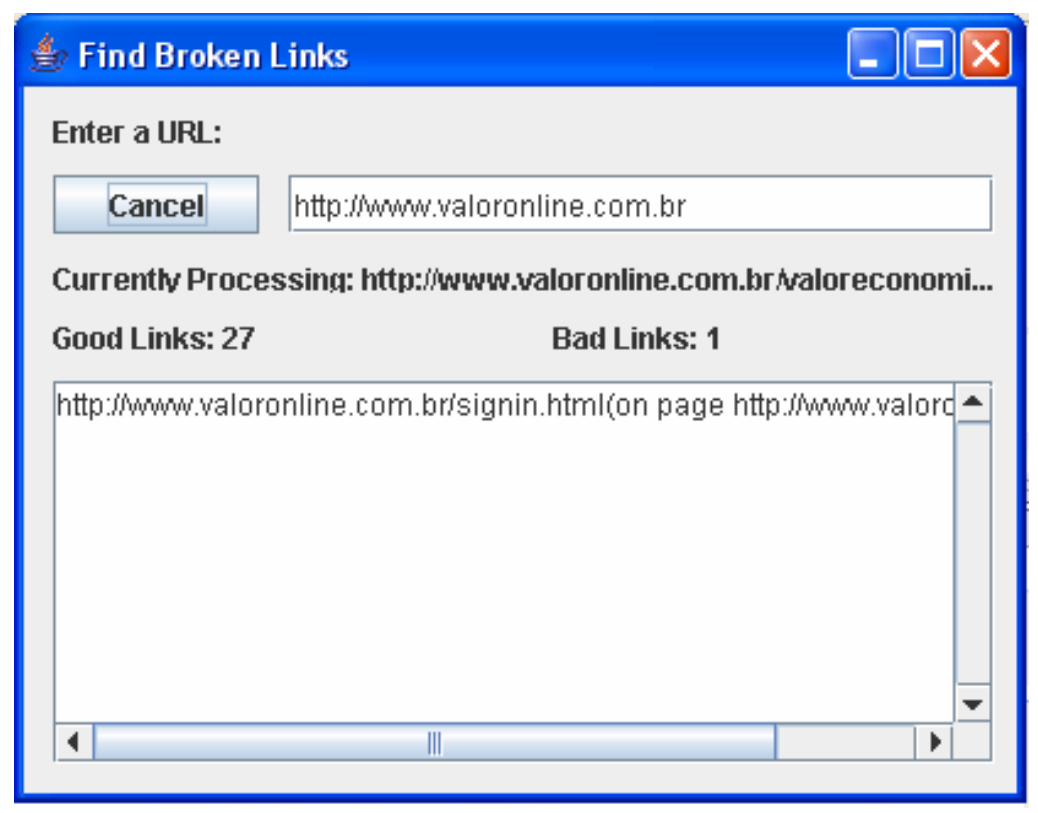

\section{Ilustração 25 - Tela após o início do programa de indexação da Web.}

A segunda fase, utilização do agente de busca Procura, a partir de palavras-chave designando atores e temas quais as páginas que possuem as informações desejadas. Também para a construção do protótipo de busca foi utilizado um software livre com algumas alterações, denominado ProcurarIndex.java.

A partir do foco estabelecido, iniciou-se a busca com a utilização de uma query na pesquisa por informações rastreadas, utilizando-se operadores simples booleanos AND e OR, palavras e prefixos representando as palavras "aquisição", "fusão", “compra” e "venda”, e os atores definidos anteriormente. A Ilustração 26 apresenta o formato da query final:

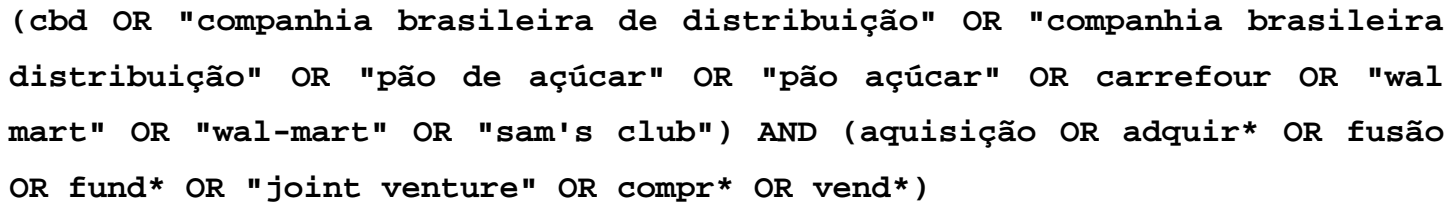

Ilustração 26 - Query utilizada para pesquisa de atores e temas.

O resultado do protótipo construído para fazer a busca por páginas de interesse está, 
parcialmente, exibido na Ilustração 27. Este resultado é composto por uma lista de páginas da web, com informações relevantes para a fase posterior de análise. Na fase de análise o pesquisador busca no conteúdo de cada uma destas páginas informações que muitas vezes são incompletas, fragmentadas, imprecisas, não para entendimento da informação em si, mas em termos do entendimento de um evento maior, um sinal antecipativo, que só terá sentido através de um agrupamento de informações, como a formação de um quebra-cabeça, termo utilizado por Lesca (2003).

Resultado(s) encontrado(s): 3

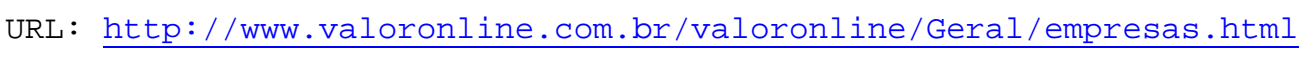

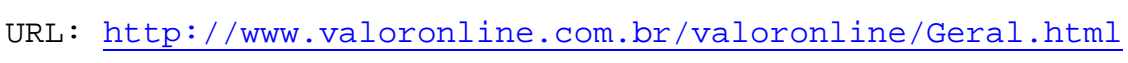

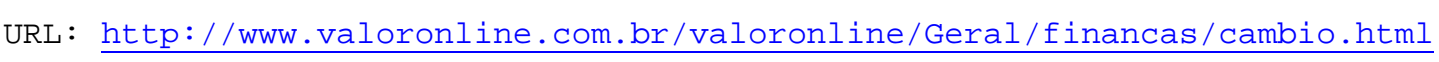

\section{Ilustração 27 - Exemplo do resultado parcial do agente de busca.}

\subsection{Análise e interpretação das informações obtidas}

Sinais antecipativos podem provocar ações por parte da organização, seja para a determinação de ações positivas no sentido de favorecimento do negócio, seja para a antecipação de uma situação que requer mais cuidado, uma situação de perigo, incluindo até uma ruptura capaz de determinar perdas significativas na sua participação no mercado em que atua.

Para detecção destes sinais foram obtidas informações do ano de 2006 (com poucas exceções do final do ano de 2005), das fontes especificadas, a partir da utilização do protótipo e do buscador de mercado Google ${ }^{\odot}$. A utilização do Google ${ }^{\circledR}$ teve como objetivo uma comparação com os resultados obtidos do protótipo desenvolvido com a finalidade de identificar possíveis desvios significativos, que invalidassem a sua utilização. As informações obtidas foram, resumidamente: 


\begin{tabular}{|c|c|c|c|c|c|c|c|c|c|}
\hline \multicolumn{10}{|c|}{$\begin{array}{c}\text { Quantidade de páginas visitadas na WEB, informações rastreadas com atores e temas definidos e } \\
\text { informações de interesse para a pesquisa }\end{array}$} \\
\hline & \multicolumn{5}{|c|}{ Protótipo } & \multicolumn{4}{|c|}{ Google } \\
\hline & $\begin{array}{l}\text { Data da } \\
\text { Leitura }\end{array}$ & $\begin{array}{l}\text { Páginas } \\
\text { Visitadas }\end{array}$ & $\begin{array}{l}\text { Páginas web } \\
\text { de saída }\end{array}$ & $\begin{array}{l}\text { Qtde. } \\
\text { Informações } \\
\text { de Interesse }\end{array}$ & $\%$ QII/PWS & $\begin{array}{l}\text { Data da } \\
\text { Leitura }\end{array}$ & $\begin{array}{l}\text { Páginas web } \\
\text { de saída }\end{array}$ & $\begin{array}{l}\text { Qtde. } \\
\text { Informações } \\
\text { de Interesse }\end{array}$ & $\%$ QII/PWS \\
\hline O Estado de São Paulo & 08-ago-06 & 13.737 & 0 & 0 & $0 \%$ & 10 -ago-06 & 24 & 1 & $4 \%$ \\
\hline Folha de São Paulo & 03-ago-06 & 208.071 & 36 & 25 & $69 \%$ & 31-ago-06 & 54 & 30 & $56 \%$ \\
\hline Valor Esconômico & 28-ago-06 & 37.745 & 43 & 20 & $47 \%$ & 28 -ago-06 & 20 & 14 & $70 \%$ \\
\hline APAS & 07-ago-06 & 22 & 0 & 0 & $0 \%$ & 22-ago-06 & 7 & 2 & $0 \%$ \\
\hline ABRASNET & 04-ago-06 & 1.601 & 14 & 4 & $29 \%$ & 22-ago-06 & 5 & 3 & $60 \%$ \\
\hline PROVAR & 23-ago-06 & 4.814 & 7 & 0 & $0 \%$ & 23-ago-06 & 9 & 0 & $0 \%$ \\
\hline Total & & 265.990 & 100 & 49 & $49 \%$ & & 119 & 50 & $42 \%$ \\
\hline
\end{tabular}

Tabela 1: Tabela com número de informações rastreadas e de interesse, por fonte

a) Rastreadas pelo protótipo, 265.990 páginas web. Não é possível apontar quantas páginas são visitadas pelo Google ${ }^{\circledast}$ dado que o mecanismo não disponibiliza esta informação;

b) Das 265.990 páginas mais as adicionadas pelo Google ${ }^{\circledR}$, foram selecionadas 219 páginas com informações relativas ao foco definido. Estas 219 páginas foram lidas e analisadas manualmente por parte do pesquisador (o número, expurgando-se repetições reduz-se para 68, demonstradas pela numeração nas tabelas 2, 3, 4, 5 e 6). Esta etapa poderia ser automatizada futuramente a partir de um algoritmo mais elaborado. Foram selecionadas informações referentes ao foco definido e que trariam, com alguma possibilidade, utilidade durante o processo de formação de sentido; 


\begin{tabular}{|c|c|c|c|c|c|}
\hline \multicolumn{6}{|c|}{ Informações extraídas da fonte Valor Econômico On Line } \\
\hline \multicolumn{6}{|c|}{ Informações extraídas em } \\
\hline & $\begin{array}{l}\text { (P)rotótipo } \\
\text { (G)loogle }\end{array}$ & Título & \begin{tabular}{|l|} 
Sinal \\
(A)ntecipativo \\
(P)otencial \\
Z - armazenar
\end{tabular} & Ator & Data \\
\hline 1 & G & À espera de um novo dono, Atacadão abre quatro lojas & SA & $\begin{array}{l}\text { Atacadão, WM, PA, } \\
\text { CAR }\end{array}$ & $15 / 08 / 06$ \\
\hline 2 & G & $\begin{array}{l}\text { A produção puxa os lucros e traz mais ânimo para } \\
\text { investir }\end{array}$ & SA & $\begin{array}{l}\text { WM, Mercado } \\
\text { varejista }\end{array}$ & $27 / 06 / 05$ \\
\hline 3 & $\mathbf{P}$ & $\begin{array}{l}\text { Abras diminui para 1,5\% previsão de crescimento das } \\
\text { vendas de supermercados em } 2006\end{array}$ & SA & $\begin{array}{l}\text { Mercado } \\
\text { Supermercadista }\end{array}$ & 03/08/06 \\
\hline 4 & $\mathbf{P}$ & $\begin{array}{l}\text { Avanço do comércio virtual e crédito ditam indicações } \\
\text { no varejo }\end{array}$ & SA & Comércio Virtual & $21 / 8 / 2006$ \\
\hline 5 & $\mathbf{P}$ & Carrefour e CVC irão vender viagens no supermercado & SP & CAR & 19/07/06 \\
\hline 6 & $\mathbf{P}$ & Casa em ordem e expansão & $\mathrm{Z}$ & PA (Casino), WM & Início 2006 \\
\hline 7 & G & Casino reforçará posição no Brasil e na Colômbia & SA & Casino,PA, WM & $24 / 05 / 06$ \\
\hline 8 & G & $\begin{array}{l}\text { Com } 149 \text { lojas, Unisuper avança em direção a Santa } \\
\text { Catarina e Paraná }\end{array}$ & SA & Unisuper & $21 / 08 / 06$ \\
\hline 9 & G & $\begin{array}{l}\text { Com mais recursos, Casas Bahia planeja expansão para } \\
2007\end{array}$ & SP & Casas Bahia & $27 / 03 / 06$ \\
\hline 10 & $\mathbf{P}$ & $\begin{array}{l}\text { Consumo aumenta, mas faturamento dos supermercados } \\
\text { diminui com preços mais baixos. }\end{array}$ & SA & $\begin{array}{l}\text { Mercado } \\
\text { Supermercadista }\end{array}$ & 03/08/06 \\
\hline 11 & $\mathbf{P}$ & $\begin{array}{l}\text { Despesa com venda de operações diminui lucro } \\
\text { trimestral da Wal-Mart }\end{array}$ & SA & WM & $15 / 08 / 06$ \\
\hline 12 & $\mathbf{P}$ & $\begin{array}{l}\text { Eletrônicos garantem crescimento de } 2,6 \% \text { nas vendas } \\
\text { de mesmas lojas do Pão de Açúcar em junho }\end{array}$ & SA & PA & $13 / 07 / 06$ \\
\hline 13 & G & Fusões de bancos crescem em todo mundo & SP & WM & $30 / 05 / 06$ \\
\hline 14 & $\mathbf{P}$ & $\begin{array}{l}\text { Lojas Wal-Mart há um ano em funcionamento têm } \\
\text { vendas 2,7\% maiores em agosto }\end{array}$ & SA & WM & $31 / 08 / 06$ \\
\hline 15 & $\mathbf{G}$ & $\begin{array}{l}\text { Os sonhos dos stakeholders e as realidades dos } \\
\text { acionistas }\end{array}$ & SP & WM & $06 / 07 / 06$ \\
\hline 16 & G & Pão de açúcar adota uma nova política de preços & SA & $\mathrm{PA}, \mathrm{WM}$ & $11 / 08 / 06$ \\
\hline 17 & G & Pão de Açúcar fecha lojas não-rentáveis no Paraná & SP & PA, Extra & $10 / 05 / 06$ \\
\hline 18 & $\mathbf{P}, \mathbf{G}$ & Persistência e paciência na rota das aquisições & SA & WM, CAR & 20/08/06 \\
\hline 19 & $\mathbf{P}$ & $\begin{array}{l}\text { Preços menores prejudicaram faturamento dos } \\
\text { supermercados em maio, diz Abras }\end{array}$ & SA & $\begin{array}{l}\text { Mercado } \\
\text { Supermercadista }\end{array}$ & $21 / 06 / 06$ \\
\hline 20 & G & $\begin{array}{l}\text { Ranking da Abras mostra disputa acirrada entre } \\
\text { Carrefour e Wal-Mart }\end{array}$ & SA & PA, CAR WM & $26 / 04 / 06$ \\
\hline 21 & $\mathbf{P}$ & $\begin{array}{l}\text { Rede Smart, criada pelo Martins, já fatura perto de } \mathrm{R} \$ 3 \\
\text { bilhões }\end{array}$ & SP & Rede Smart (Martins) & $23 / 05 / 06$ \\
\hline 22 & $\mathbf{P}$ & $\begin{array}{l}\text { Reestruturação reduz lucro do Pão de Açúcar no } \\
\text { segundo trimestre }\end{array}$ & SA & PA, CAR & $10 / 08 / 06$ \\
\hline 23 & $\mathbf{P}$ & $\begin{array}{l}\text { Vendas de supermercados caíram 4,04\% em maio, diz } \\
\text { Abras }\end{array}$ & SA & $\begin{array}{l}\text { Mercado } \\
\text { Supermercadista }\end{array}$ & $21 / 06 / 06$ \\
\hline 24 & $\mathbf{P}$ & $\begin{array}{l}\text { Vendas de supermercados recuam } 2,28 \% \text { em junho e } \\
\text { baixam } 2,74 \% \text { no semestre, diz Abras }\end{array}$ & SA & $\begin{array}{l}\text { Mercado } \\
\text { Supermercadista }\end{array}$ & 03/08/06 \\
\hline 25 & $\mathbf{P}$ & $\begin{array}{l}\text { Vendas do Carrefour crescem 9,2\% no Brasil no } \\
\text { segundo trimestre }\end{array}$ & SA & CAR & 13/07/06 \\
\hline 26 & $\mathbf{P}$ & $\begin{array}{l}\text { Vendas do grupo Pão de Açúcar caem 3,5\% em maio no } \\
\text { conceito de mesmas lojas }\end{array}$ & SA & $\mathrm{PA}$ & 13/06/06 \\
\hline 27 & $\mathbf{P}$ & $\begin{array}{l}\text { Vendas dos supermercados brasileiros caem 3,37\% em } \\
\text { julho ante } 2005\end{array}$ & SA & $\begin{array}{l}\text { Mercado } \\
\text { Supermercadista }\end{array}$ & 31/08/06 \\
\hline 28 & $\mathbf{P}$ & $\begin{array}{l}\text { Vendas nas lojas da Wal-Mart abertas há } 12 \text { meses nos } \\
\text { EUA sobem 1,2\% em junho }\end{array}$ & SP & WM & 06/07/06 \\
\hline 29 & $\mathbf{P}, \mathbf{G}$ & $\begin{array}{l}\text { Wal-Mart abandona Alemanha e passa suas lojas para } \\
\text { Metro }\end{array}$ & SP & WM & 28/07/06 \\
\hline 30 & $\mathbf{P}$ & $\begin{array}{l}\text { Wal-Mart divulga previsão de crescimento de } 2,4 \% \text { nas } \\
\text { vendas de julho }\end{array}$ & SA & WM & $31 / 07 / 06$ \\
\hline 31 & $\mathbf{P}$ & $\begin{array}{l}\text { Wal-Mart, Pão de Açúcar e Carrefour estão na reta final } \\
\text { pelo Atacadão }\end{array}$ & SA & $\begin{array}{c}\text { Atacadão. PA, WM, } \\
\text { CAR }\end{array}$ & 07/07/06 \\
\hline
\end{tabular}

Tabela 2: Demonstrativo de informações rastreadas no site do ValorOnLine 


\begin{tabular}{|c|c|c|c|c|c|}
\hline \multicolumn{6}{|c|}{ Informações extraídas da fonte Folha de São Paulo On Line } \\
\hline \multicolumn{6}{|c|}{ Informações extraídas em } \\
\hline & $\begin{array}{l}\text { (P)rotótipo } \\
\text { (G)loogle }\end{array}$ & Título & $\begin{array}{l}\text { Sinal } \\
\text { (A)ntecipativo } \\
\text { (P)otencial } \\
\text { Z - armazenar }\end{array}$ & Ator & Data \\
\hline 32 & $\mathbf{P}, \mathbf{G}$ & Bancos agora almejam varejo regional & SA & $\begin{array}{l}\text { M.Supermercadista, } \\
\text { S. Bancário }\end{array}$ & $12 / 06 / 06$ \\
\hline 33 & $\mathbf{P}, \mathbf{G}$ & $\begin{array}{l}\text { BNDES aprova financiamento de } \mathrm{R} \$ 30 \text { milhões para } \\
\text { Magazine Luiza }\end{array}$ & SP & $\begin{array}{l}\text { M. Luiza, } \\
\text { PA,Americanas, } \\
\text { Shoptime }\end{array}$ & $13 / 02 / 06$ \\
\hline 34 & P, G & BNDES aprova $\mathrm{R} \$ 34,5 \mathrm{mi}$ para financiar PC Popular & SP & M. Luiza, PA & $13 / 02 / 06$ \\
\hline 35 & G & $\begin{array}{l}\text { Carrefour compra dez supermercados BIG e amplia } \\
\text { concentração no setor }\end{array}$ & $\mathrm{Z}$ & CAR, BIG & $8 / 6 / 2005$ \\
\hline 36 & $\mathbf{P}, \mathbf{G}$ & Carrefour cresce mais que grupo Pão de Açúcar & SA & CAR, PA & $14 / 07 / 06$ \\
\hline 37 & $\mathbf{P}, \mathbf{G}$ & Carrefour vai contratar 165 profissionais em São Paulo & SP & CAR & $10 / 03 / 06$ \\
\hline 38 & $\mathbf{P}, \mathbf{G}$ & $\begin{array}{l}\text { Dólar cai e Bovespa diminui ritmo de alta; risco cai } \\
\text { para menor valor na história }\end{array}$ & SA & PA, M. Financeiro & $09 / 08 / 06$ \\
\hline 39 & $\mathbf{P}, \mathbf{G}$ & $\begin{array}{l}\text { Empresas brasileiras sobem de posição em ranking da } \\
\text { "Fortune" }\end{array}$ & $\mathrm{SP}$ & WM & $12 / 07 / 06$ \\
\hline 40 & G & $\begin{array}{l}\text { Gigante Wal-Mart compra lojas do Sonae no Brasil por } \\
\mathrm{R} \$ 1,7 \text { bi }\end{array}$ & $\mathrm{Z}$ & WM, Sonae, CAR & $14 / 12 / 05$ \\
\hline 41 & $\mathbf{P}, \mathbf{G}$ & $\begin{array}{l}\text { Lucro do Pão de Açúcar cai 30\% em } 2005 \text { e atinge R\$ } \\
257 \text { milhões }\end{array}$ & SP & PA & $09 / 03 / 06$ \\
\hline 42 & $\mathbf{P}, \mathbf{G}$ & $\begin{array}{l}\text { Lucro do Pão de Açúcar cai 36\% no segundo trimestre e } \\
\text { atinge R } \$ 41 \text { milhões }\end{array}$ & SP & PA & $08 / 08 / 06$ \\
\hline 43 & $\mathbf{P}, \mathbf{G}$ & Lucro do Wal-Mart cai $26 \%$ no segundo trimestre & SA & WM & $15 / 08 / 06$ \\
\hline 44 & $\mathbf{P}, \mathbf{G}$ & Mesmo em baixa, juro de loja é maior no Brasil & SP & WM, PA, Casino & $20 / 02 / 06$ \\
\hline 45 & $\mathbf{G}$ & $\begin{array}{l}\text { Pão de Açúcar compra Coopercitrus e amplia presença } \\
\text { no interior de SP }\end{array}$ & SP & PA & $4 / 5 / 2005$ \\
\hline 46 & $\mathbf{P}, \mathbf{G}$ & $\begin{array}{l}\text { Pão de Açúcar fecha } 2005 \text { com crescimento de 2,6\% } \\
\text { nas vendas }\end{array}$ & SP & PA & $12 / 01 / 06$ \\
\hline 47 & $\mathbf{P}, \mathbf{G}$ & $\begin{array}{l}\text { Pão de Açúcar mantém liderança em ranking de } \\
\text { supermercados pelo } 3^{\circ} \text { ano }\end{array}$ & $\mathrm{Z}$ & PA, CAR, WM & $12 / 04 / 06$ \\
\hline 48 & $\mathbf{P}, \mathbf{G}$ & $\begin{array}{l}\text { Pão de Açúcar planeja investir R } \$ 935 \text { milhões neste } \\
\text { ano }\end{array}$ & SA & PA & $27 / 03 / 06$ \\
\hline 49 & $\mathbf{P}, \mathbf{G}$ & Pão de Açúcar planeja investir R\$ 1,5 bi até 2007 para a & SA & PA & $12 / 01 / 06$ \\
\hline 50 & $\mathbf{P}, \mathbf{G}$ & Sonae quer comprar Portugal Telecom & $\mathrm{Z}$ & Sonae, CAR, WM & $07 / 02 / 06$ \\
\hline 51 & $\mathbf{P}, \mathbf{G}$ & Supermercados demitem mais de 1.700 & SA & PA, CAR, WM & $06 / 06 / 06$ \\
\hline 52 & $\mathbf{G}$ & $\begin{array}{l}\text { Veja raio-x da rede Sonae no Brasil, comprada hoje } \\
\text { pelo Wal-Mart }\end{array}$ & SP & WM, Sonae & $14 / 12 / 2005$ \\
\hline 53 & $\mathbf{P}, \mathbf{G}$ & Venda do Atacadão está em banho-maria & SA & $\begin{array}{l}\text { Atacadão, WM, PA, } \\
\text { CAR }\end{array}$ & $03 / 07 / 06$ \\
\hline 54 & $\mathbf{P}, \mathbf{G}$ & $\begin{array}{l}\text { Vendas de supermercados caem 1,5\% em fevereiro, diz } \\
\text { Abras }\end{array}$ & SA & $\begin{array}{l}\text { M. Supermercadista, } \\
\text { PA, CAR, WM }\end{array}$ & $21 / 03 / 06$ \\
\hline 55 & $\mathbf{P}, \mathbf{G}$ & $\begin{array}{l}\text { Vendas do Grupo Pão de Açúcar crescem 3,6\%, a R\$ } \\
1,255 \text { bi, em junho }\end{array}$ & SA & PA & $13 / 07 / 06$ \\
\hline 56 & $\mathbf{P}, \mathbf{G}$ & $\begin{array}{l}\text { Vendas nos supermercados avançam } 0,66 \% \text { e atingem } \\
\text { R\$ } 105 \text { bi em } 2005\end{array}$ & SA & $\begin{array}{l}\text { M. Supermercadista, } \\
\text { PA, CAR, WM }\end{array}$ & $26 / 01 / 06$ \\
\hline 57 & $\mathbf{P}, \mathbf{G}$ & $\begin{array}{l}\text { Wal-Mart inaugura loja em Sorocaba e inicia disputa } \\
\text { por vice-liderança }\end{array}$ & SA & WM, CAR & $25 / 01 / 06$ \\
\hline 58 & G & Wal-Mart paga R $\$ 1,6$ bilhão por rede do Sul & SP & WM, Sonae & $21 / 11 / 2005$ \\
\hline 59 & $\mathbf{P}, \mathbf{G}$ & Wal-Mart planeja 150 mil contratações na China & SA & WM & $20 / 03 / 06$ \\
\hline 60 & $\mathbf{P}, \mathbf{G}$ & $\begin{array}{l}\text { Wal-Mart pode passar Carrefour e virar } 2^{\circ} \text { maior } \\
\text { supermercado do país }\end{array}$ & SA & WM, CAR, PA & $26 / 04 / 06$ \\
\hline 61 & $\mathbf{P}, \mathbf{G}$ & Wal-Mart traça plano para dominar varejo brasileiro & SA & WM, CAR & $08 / 07 / 06$ \\
\hline
\end{tabular}

Tabela 3: Demonstrativo de informações rastreadas no site da Folha de São Paulo 


\begin{tabular}{|c|c|c|c|c|c|}
\hline \multicolumn{6}{|c|}{ Informações extraídas da fonte ABRASNET } \\
\hline \multicolumn{6}{|c|}{ Informações extraídas em } \\
\hline & $\begin{array}{l}\text { (P)rotótipo } \\
\text { (G)loogle }\end{array}$ & Título & \begin{tabular}{|l|} 
Sinal \\
(A)ntecipativo \\
(P)otencial \\
Z - armazenar \\
\end{tabular} & Ator & Data \\
\hline 62 & $\mathbf{P}, \mathbf{G}$ & Mercados - SuperHiper abril de 2006 & SA & WM, CAR, PA & abr-06 \\
\hline 63 & P, G & Perspectivas - SuperHiper Dezembro de 2005 & SA & WM, CAR, PA & dez-05 \\
\hline 64 & $\mathbf{P}, \mathbf{G}$ & Concentração - SuperHiper Maio de 2006 & SA & WM, CAR, PA & mai-06 \\
\hline 65 & $\mathbf{P}$ & Gestores - SuperHiper Junho de 2006 & SA & WM, CAR & jun-06 \\
\hline
\end{tabular}

Tabela 4: Demonstrativo de informações rastreadas no site da ABRAS

\begin{tabular}{|l|c|c|c|c|c|}
\hline \multicolumn{7}{|c|}{ Informações extraídas da fonte APAS } \\
\hline \multicolumn{2}{|c|}{ Informações extraídas em } \\
\hline $\begin{array}{l}\text { (P)rotótipo } \\
\text { (G)loogle }\end{array}$ & \multicolumn{1}{|c|}{ Título } & $\begin{array}{l}\text { Sinal } \\
\text { (A)ntecipativo } \\
\text { (P)otencial } \\
\text { Z - armazenar }\end{array}$ & Ator & Data \\
\hline 66 & G & Pão de Açucar muda direção executiva & SA & PA & $26 / 4 / 2006$ \\
\hline 67 & G & Uma chave para crescer & SA & PA & $01 / 2006$ \\
\hline
\end{tabular}

Tabela 5: Demonstrativo de informações rastreadas no site da APAS

\begin{tabular}{|l|c|c|c|c|c|}
\hline \multicolumn{5}{|c|}{ Informações extraídas da fonte O Estado de São Paulo } \\
\hline & $\begin{array}{l}|c| \\
\text { (P)rotótipo } \\
\text { (G)loogle }\end{array}$ & Título & $\begin{array}{l}\text { Sinal } \\
\text { (A)ntecipativo } \\
\text { (P)otencial } \\
\text { Z - armazenar }\end{array}$ & Ator extraídas em & Data \\
\hline $\mathbf{6 8}$ & G & Wal Mart comunica oficialmente compra do Sonae & Z & WM, Sonae & $5 / 1 / 2006$ \\
\hline
\end{tabular}

Tabela 6: Demonstrativo de informações rastreadas no site do Estado de São Paulo

Observação: não foram encontradas informações referentes ao foco definido no site do PROVAR.

c) Dessas 68 páginas foram criadas tabelas com as informações sobre Título, Fonte, Data de publicação, Data de leitura, Comentários e Atores envolvidos. A tabela 7 a seguir é um exemplo das 68 tabelas anexas ao trabalho. 


\begin{tabular}{|l|c|c|}
\hline \multicolumn{3}{|l|}{ Wal-Mart, Pão de Açúcar e Carrefour estão na reta final pelo Atacadão } \\
\hline Fonte & Data de Publicação & Data de Rastreamento \\
\hline Valor OnLine & $07 / 07 / 2006$ & $26 / 08 / 2006$ \\
\hline Informação Essencial & \\
\hline Dos seis grupos que olharam a rede, estão na disputa apenas três: Wal-Mart, Carrefour e Pão de \\
Açúcar. O que está em jogo é a liderança do varejo - nas mãos do Pão de Açúcar desde 2000.
\end{tabular}

De controle familiar, a rede Atacadão opera um bem sucedido modelo de negócio - que mistura atacado e varejo. $\mathrm{O}$ que chama atenção dos interessados é o seu baixo custo de operação: a rede não aceita nem mesmo cartão de crédito para não onerar a sua margem - que já é apertada. A maior parte das vendas é paga em dinheiro, na boca do caixa.

Extremamente simples, as suas 35 lojas são bem localizadas e algumas delas chegam a faturar R \$ 20 milhões ao mês. O volume impressiona, Carrefour, Wal-Mart e Pão de Açúcar têm poucas unidades com um faturamento tão expressivo. O Atacadão fatura algo próximo a $\mathrm{R} \$ 5$ bilhões por ano.

O seu modelo de negócio não chega a se encaixar perfeitamente em nenhum formato dos interessados. O Wal-Mart é o que mais se aproxima, com a rede Sam's Club. Pão de Açúcar e Carrefour não têm operações do gênero.

Depois de ter feito aquisições desastrosas nos últimos anos - algumas com sérios problemas fiscais - o Carrefour tornou-se um comprador extremamente cuidadoso. O Valor apurou que o grupo francês quer se certificar de que o Atacadão está livre de qualquer pendência. De capital fechado, o atacadista volta e meia é acusado de ter sérios problemas fiscais.

Fonte que acompanha a negociação diz que, para evitar qualquer dor de cabeça ao futuro controlador, contingências fiscais, trabalhistas e civis estão sendo estimadas e serão colocadas numa conta à parte (na prática, uma conta gráfica, ou " escrow account ", em inglês). O valor pode chegar a US\$ 150 milhões.

Na compra do Sonae, pelo Wal-Mart, a "escrow account" chegou a US\$ 200 milhões e o negócio foi fechado por US\$ 720 milhões. A venda do Atacadão pode superar US\$ 700 milhões. Os mais otimistas acham que o negócio pode bater na casa do US\$ 1 bilhão. Procurado, o Atacadão não se manifestou.

Análise da Informação

O que está em questão é a liderança no ranking supermercadista.

Temas Atores

Aquisição Wal-Mart, Pão de Açúcar, Carrefour, Atacadão

\section{URL da fonte}

hthttp://www.valoronline.com.br//valoronline/Geral/empresas/37/Wali Mart+Pao+de+Acucar+e+Carrefour+estao+na+reta+final+pelo+Atacadao, $37,3779803 . \mathrm{htm}$

Tabela 7: Mapeamento de informação rastreada 
d) Dessas 68 tabelas, 72 informações eram prováveis ou potenciais sinais antecipativos. Denominados potenciais dado que não possuem significado quando analisados de forma independente, mas potencialmente podem formar um sinal antecipativo em momento de criação de sentido através da formação de puzzles (quebra-cabeças) como nas Ilustrações 28, 29, 30, 31 e 32; 


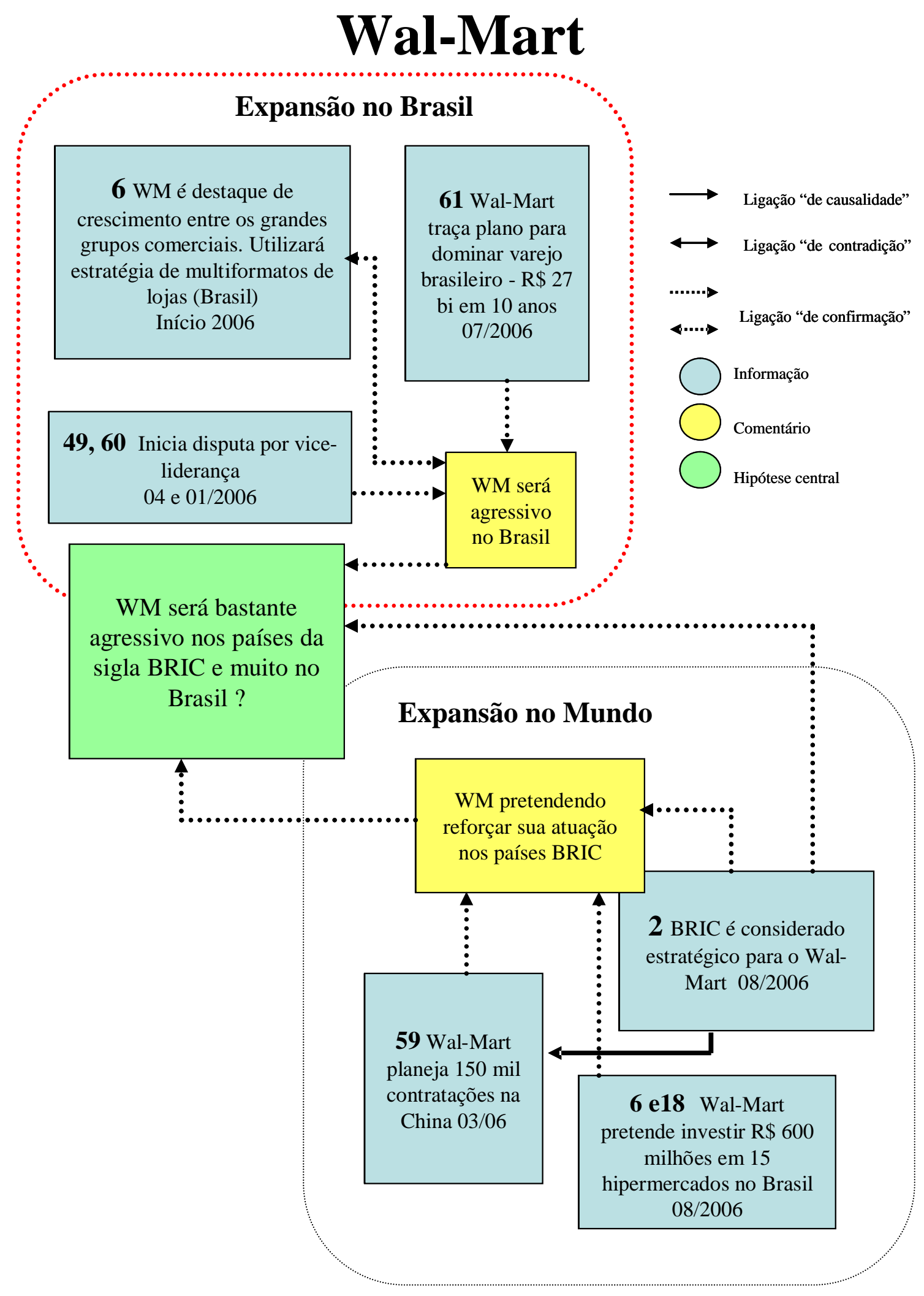

Ilustração 28 - Puzzle sobre o Wal-Mart 
O Wal-Mart, maior rede de comércio varejista do mundo, até a pouco estava ainda adequando seu modelo de gestão à realidade brasileira. Mas em 2006 começará a ser mais agressivo. Segundo Wilson Mello Neto, vice-presidente de assuntos corporativos, o Brasil é um país estratégico para o Wal-Mart.

Os mercados da área de comércio varejista com maior potencial de expansão e crescimento nos próximos tempos são os designados pela sigla BRIC - Brasil, Rússia, Índia e China.. Na China, por exemplo, o grupo pretende contratar 150 mil funcionários nos próximos cinco anos. A empresa planeja a abertura de 20 lojas no país neste ano. Já existem 56 lojas da WalMart na China contra, por exemplo, as 78 de que dispunha o Carrefour até o fim de 2005 (Valor OnLine - 15/08/2006).

Em menos de dois anos o Wal-Mart foi responsável pelo desembolso de US\$ 1 bilhão em aquisições. Daqui para frente, prevêem analistas, o grupo irá brigar pela liderança, seja por meio de novas compras ou com a construção de seus próprios hipermercados.

Em termos de investimentos previstos o Wal-Mart projetou para 2006 gastos de R\$ 600 milhões na inauguração de 15 novos pontos comerciais, utilizando uma estratégia de multiformatos de lojas. Para fins de comparação, o Carrefour informou que deve investir R\$ 700 milhões na abertura de 15 lojas no país e o Pão de Açúcar pretende investir R\$ 1,5 bilhão no biênio 2006/2007 na abertura de 16 a 20 hipermercados e entre 40 a 60 supermercados, monstantes muito parecidos (Valor OnLine - Início 2006).

Em reunião fechada nos EUA, executivos do grupo previram para o Brasil um faturamento anual de R \$ 40 bilhões (valor nominal) daqui a dez anos, que seriam R 27 bilhões a valor presente, o equivalente à soma da receita da cadeia americana e do grupo Pão de Açúcar no ano de 2005. Se conseguir atingir os R 27 bilhões, será uma expansão média real anual até 2016 de 8,73\%, muito superior à taxa de crescimento do setor nos últimos anos, assim como a prevista para os próximos dez anos. Uma expansão nesse patamar, de quase 9\%, só será possível roubando mercado alheio, dizem especialistas. Seja por um veloz crescimento orgânico ou por aquisições. Segundo eles, é nesse segundo caso que o crescimento pode ser mais acelerado (Folha OnLine 08/07/2006). 
Os grandes varejistas têm focado seus objetivos em três frentes :

a) O mercado de baixa renda. O Carrefour, por exemplo, deslanchou em São Paulo a bandeira Dia\%, modelo de supermercados "hard discount" trazido da Espanha e o Wal-Mart está testando no Nordeste a bandeira Balaio, uma rede de pequenos supermercados localizados em áreas de menor poder aquisitivo (Valor OnLine 23/05/2006.).

b) Os mercados regionais do Norte e o Nordeste, onde está a maior parte dos domicílios brasileiros e do consumo no País, $26 \%$ e $27 \%$, respectivamente. No entanto, apenas $14 \%$ dos consumidores dessas regiões fazem suas compras nos supermercados. A rede Wal-Mart há dois anos adquiriu o Bompreço, a maior rede do Nordeste (SuperHiper - 04/2006).

c) Existe um movimento para o interior de São Paulo. O Wal-Mart inaugurou a sua primeira loja em Sorocaba, que recebeu $\mathrm{R} \$ 40$ milhões em investimentos. Com a nova filial, a rede varejista de origem norte-americana dá início à disputa pela vice-liderança do setor supermercadista brasileiro. Para encostar no Carrefour, o Wal-Mart já anunciou que pretende abrir 15 novos pontos. Entre as novas lojas está a unidade de Franca (400 km de São Paulo), que deve ser inaugurada até o final do ano (Folha OnLine - 25/01/2006).

Quanto ao atacado, a disputa ficou mais competitiva com o avanço de grandes empresas, como o Atacadão, o Makro e o próprio Wal-Mart. O grupo possui duas bandeiras de atacado, o Sam‘s Club e o Maxxi, rede comprada do Sonae na região Sul. 


\section{Pão de Açúcar}

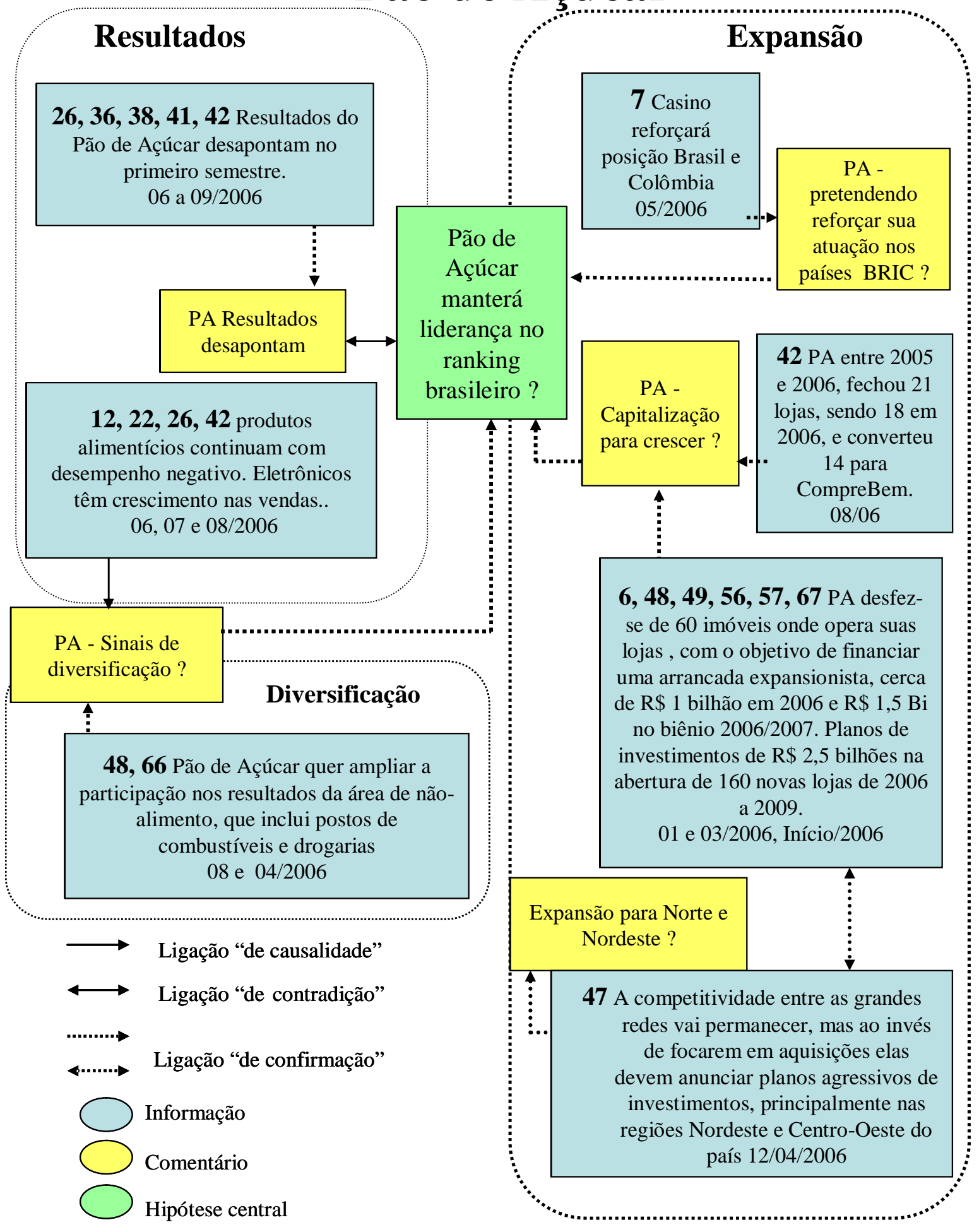

Ilustração 29 - Puzzle sobre o Pão de Açúcar 
A Ilustração 29 retrata o puzzle referente ao Grupo Pão de Açúcar. As informações do Puzzle são resumidas de forma proposital para permitir a visão geral de um cenário que pode ser visto e analisado como um todo. Abaixo, estão as informações que originaram estes sinais antecipativos. As conclusões extraídas destes sinais estão no final do texto. O objetivo não é esgotar possibilidades mas formar sentido em informações fragmentadas e aparentemente desconexas.

Desde 1999 o Grupo Pão de Açúcar divide o controle com o Groupe Casino, o que permitiu um aporte de R $\$ 1$ bilhão, reduzindo o endividamento líquido da empresa e viabilizando um plano de investimentos de, aproximadamente, $\mathrm{R} \$ 2,5$ bilhões na abertura de 160 novas lojas (120 supermercados e 40 hipermercados) de 2006 a 2009. Segundo Francis Mauger, diretor geral da varejista francesa para a América Latina, "Para o biênio 2006/2008, o grupo fixou como objetivo reforçar sua posição na América Latina, com foco no Brasil e na Colômbia". Na França, o Casino possui 7 mil pontos e opera lojas que vão desde supermercados sofisticados ao "hard discount", direcionado ao público de baixa renda. O Pão de Açúcar, diz Mauger, tem acesso aos formatos que o Casino opera no exterior e poderia trazê-los ao Brasil. Até setembro de 2005, a CBD (Cia. Brasileira de distribuição), dona das bandeiras Pão de Açúcar, Extra Eletro, Comprebem e Sendas, contava com 555 pontos de venda no país (Folha OnLine de 12/01/06).

Quanto aos mercados regionais mais promissores ao setor supermercadista, o destaque é para o Norte e o Nordeste, onde está a maior parte dos domicílios brasileiros e do consumo no País, 26\% e 27\%, respectivamente (SuperHiper de 04/2006.).

O Grupo fechou 2005 mais uma vez na liderança, com participação de 15,2\% do mercado (abaixo dos 15,8\% em 2004) e faturamento de R \$ 16,169 bilhões. Mas obteve um resultado fraco em termos de lucro líquido 30.5\% inferior em 2005 na comparação com mesmo período de 2004. Em contrapartida, no conceito mesmas lojas ${ }^{1}$, o crescimento nominal acumulado no ano foi de $2,6 \%$, impulsionado pela boa performance registrada pelos produtos nãoalimentícios que cresceram $12,5 \%$ no período.

No segundo trimestre de 2006 o lucro líquido do grupo foi $36 \%$ menor se comparado ao de

\footnotetext{
${ }^{1}$ Lojas com mais de 12 meses de operação, onde são expurgados valores de abertura e operação inicial.
} 
igual período de 2005. Os investidores reagiram mal ao balanço do Pão de Açúcar, cujos resultados do trimestre ficaram aquém das expectativas dos analistas da Merrill Lynch e do Credit Suisse, que divulgaram relatórios sobre a varejista. Mas o Pão de Açúcar não é um "caso isolado", aponta a Merril Lynch, lembrando que as demais redes também apresentaram um fraco desempenho nas vendas em lojas comparáveis. O setor está sendo afetado pela deflação nos preços dos alimentos.

A venda de produtos alimentícios continua com desempenho negativo (ValoOnLine de 13/07/06). A deflação nos preços dos alimentos coloca em xeque uma forte tradição dos supermercados brasileiros: as ofertas. O varejo sempre focou sua artilharia nas promoções. Hoje, porém, com a deflação, nem as lojas nem as indústrias têm margem de manobra suficiente para conceder descontos pontuais nos preços para, depois, aumentá-los novamente (ValorOnLine de 11/08/06.).

Problemas com a área de alimentos levaram o Grupo Pão de Açúcar a mudar sua diretoriaexecutiva. Rodolfo Landim, ex-presidente da BR Distribuidora, assume o cargo de diretorexecutivo comercial de não-alimentos da rede. A contratação está confirmada e Landim tem a missão de ampliar a participação nos resultados da área de não-alimento, que inclui postos de combustíveis (Site APAS de 26/04/2006.).

Lund, presidente da Informa Publicações, que edita a revista Supermercado Moderno, avalia que o ritmo de aquisições no setor vai desacelerar. "Existem menos possibilidades de aquisições hoje. As empresas que ficaram têm um desempenho muito positivo, o que exigiria um desembolso muito maior de recursos por parte dos compradores", afirmou Lund.

Para Lund, a competitividade entre as grandes redes vai permanecer, mas ao invés de focarem em aquisições elas devem anunciar planos agressivos de investimentos, principalmente nas regiões Nordeste e Centro-Oeste do país (FolhaOnLine 31/08/06).

\section{Conclusão}

O Groupe Casino que detém, aproximadamente, 62\% da CBD (Cia. Brasileira de Distribuição, dona do Pão de Açúcar) é um grupo forte, com 7.000 lojas somente na França. 
O grupo declara claramente ter grande interesse na América Latina, principalmente no Brasil e na Colômbia.

As indicações apontam que os investimentos previstos para os anos de 2006-2009 no Brasil, da ordem de $\mathrm{R} \$ 2,5$ bilhões, serão para duas frentes:

a) Crescimento orgânico forte no mercado supermercadista brasileiro, principalmente nos mercados Norte e Nordeste;

b) Deve ocorrer forte diversificação na abertura de negócios na área não-alimentícia, na área de eletro-eletrônicos, postos de gasolina e drogarias.

A manutenção do primeiro lugar no ranking ABRAS dependerá da concretização destes investimentos e de como serão os comportamentos dos demais líderes do ranking, Carrefour e Wal-Mart. 


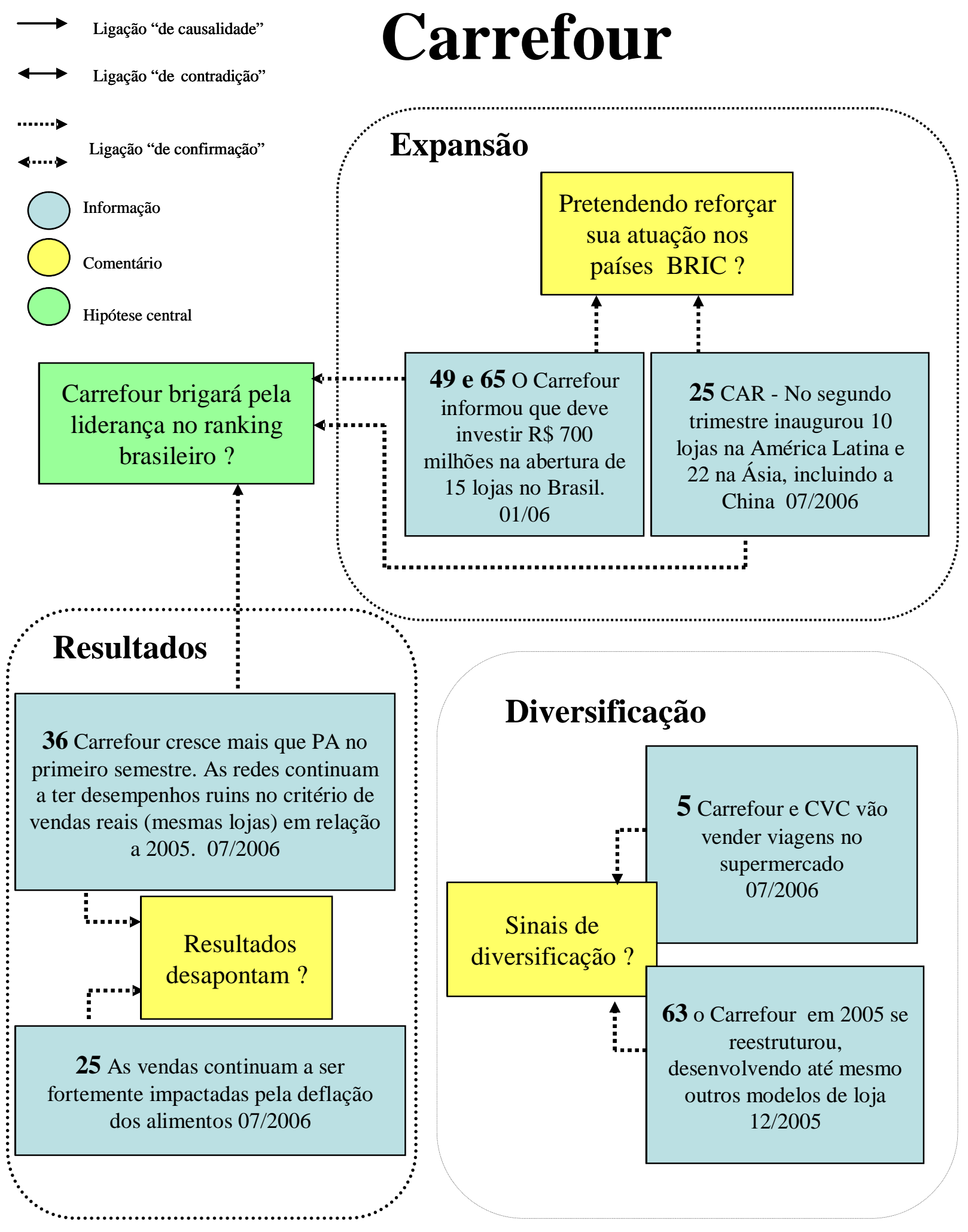


Em 2005 a rede Carrefour teve sua posição no ranking ABRAS de supermercados comprometida, com o Wal-Mart, terceiro colocado, encostando na segunda posição. As duas redes de supermercados devem travar um batalha acirrada para aumentar a participação de mercado e disputar o segundo lugar no ranking do setor em 2006 (ValorOnLine 26/04/2006.). Simultaneamente o Carrefour persegue a posiçãode líder do ranking, embora distante. O faturamento do Carrefour foi de R\$ 12,5 bi e o do Pão de Açúcar de R\$ 16,2 bi.

No segundo trimestre de 2006, o resultado do Carrefour foi melhor do que o do Pão de Açúcar, mas as redes continuam a ter desempenhos ruins no critério de vendas reais (mesmas lojas) em relação a 2005 (Folha OnLine - 14/07/2006.). Segundo o ValorOnLine de 13 de julho de 2006, a empresa declarou que as vendas continuam a ser fortemente impactadas pela deflação dos preços dos alimentos e pela decisão de reposicionar preços.

A empresa vem em um processo de reestruturação, com fechamento em 2005 de toda a sua operação com a bandeira de supermercados Champion e incentivo à operação dos hipermercados, seu principal formato de loja desde que chegou ao País, na década de 80 . O Carrefour abrirá mais 16 unidades somente este ano, com investimentos de R 700 milhões (SuperHiper 06/2006.).

No segundo trimestre deste ano, a varejista inaugurou 232 lojas em todo o mundo, entre as quais 10 na América Latina e 22 na Ásia, incluindo-se a China, onde já dispunha de 78 até o final de 2005. São, no mundo, 12.185 lojas (Valor OnLine - 15/08/2006.).

Para o varejo alimentar, o reforço da área de serviços e outros negócios, como farmácias e postos de gasolina, é visto como uma maneira de aumentar a fidelidade do consumidor e oferecer um diferencial. A rede Carrefour opera 49 postos de gasolina e 32 farmácias pretende atingir 50 atá o final do ano. "Já vínhamos focando nos postos e as farmácias, faltava reestruturar o turismo", diz Ribeiro. "Criar o projeto e colocar na loja não significa que vai funcionar, mas definimos uma estratégia muito clara" (ValorOnLine - 19/07/2006.). 


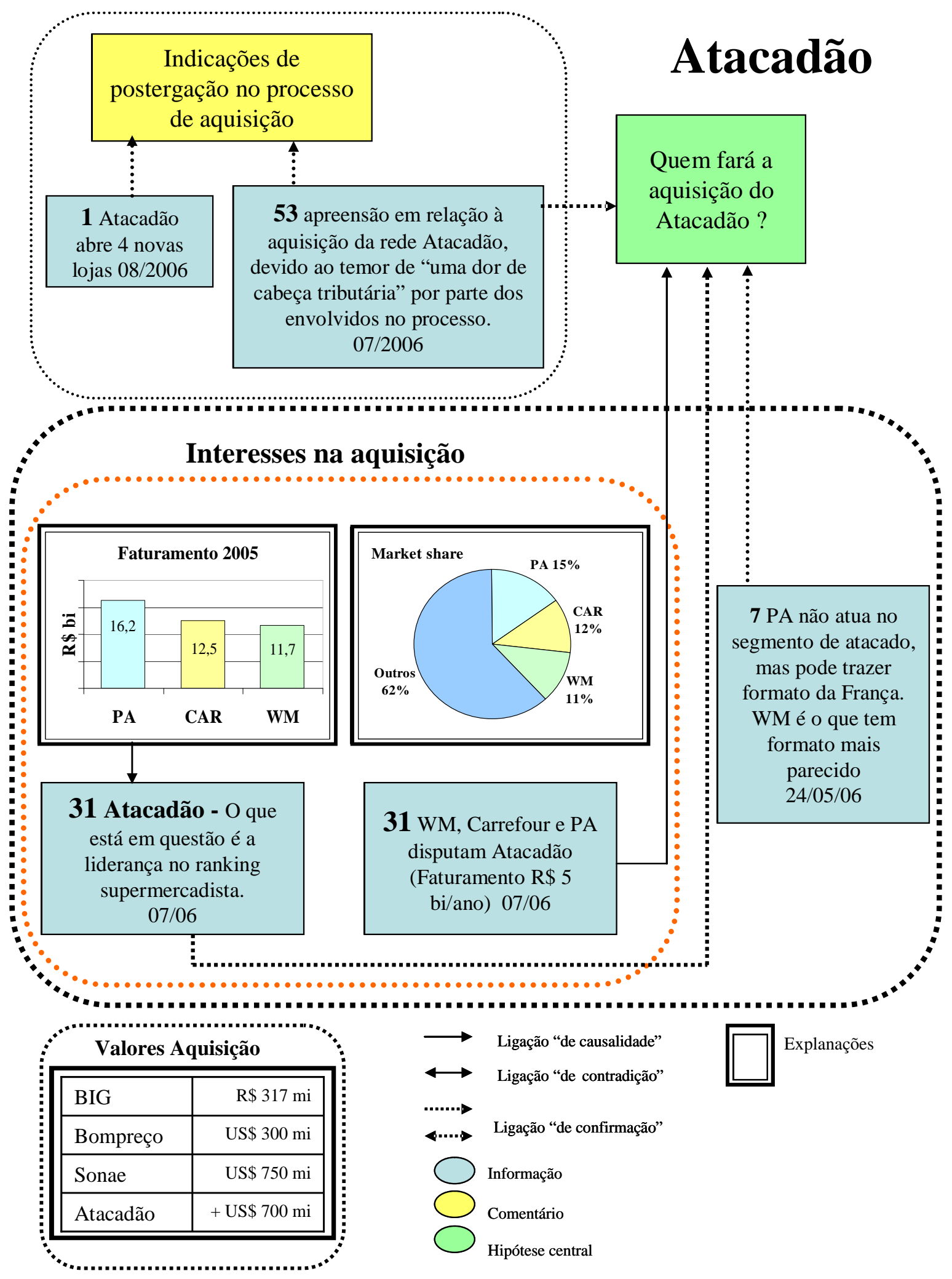


O Pão de Açúcar, Carrefour e Wal-Mart estão envolvidos no maior processo de aquisição em andamento no momento, o da rede Atacadão. A rede opera um modelo de negócio, que mistura atacado e varejo.

Com 35 lojas bem localizadas, algumas chegam a faturar $\mathrm{R}$ \$ 20 milhões ao mês, um número que causa impacto, já que Carrefour, Wal-Mart e Pão de Açúcar têm poucas unidades com um faturamento tão expressivo. $\mathrm{O}$ Atacadão fatura algo próximo a $\mathrm{R} \$ 5$ bilhões por ano. Dado que os faturamentos de 2005 do Pão de Açúcar, Carrefour e Wal-Mart são, respectivamente, $\mathrm{R}$ \$ 16.2 bilhões, $\mathrm{R}$ \$ 12,5 bilhões e $\mathrm{R}$ \$ 11,7 bilhões, esta aquisição pode definir uma nova composição para os primeiros colocados do ranking da ABRAS.

O seu modelo de negócio não chega a se encaixar perfeitamente em nenhum formato dos interessados, o Wal-Mart é o que mais se aproxima e o Pão de Açúcar pode importar o formato do Groupe Casino francês.

Porém, tudo indica que a aquisição está em compasso de espera. Primeiramente, existe um temor de que a compra do Atacadão se transforme numa questão bastante onerosa, devido a passsivos tributários ou trabalhistas. Em segundo lugar, o Atacadão acaba de abrir quatro novas lojas enquanto aguarda a definição do processo.

Quem deve adquirir a rede ainda é uma incógnita até a finalização desta pesquisa. 


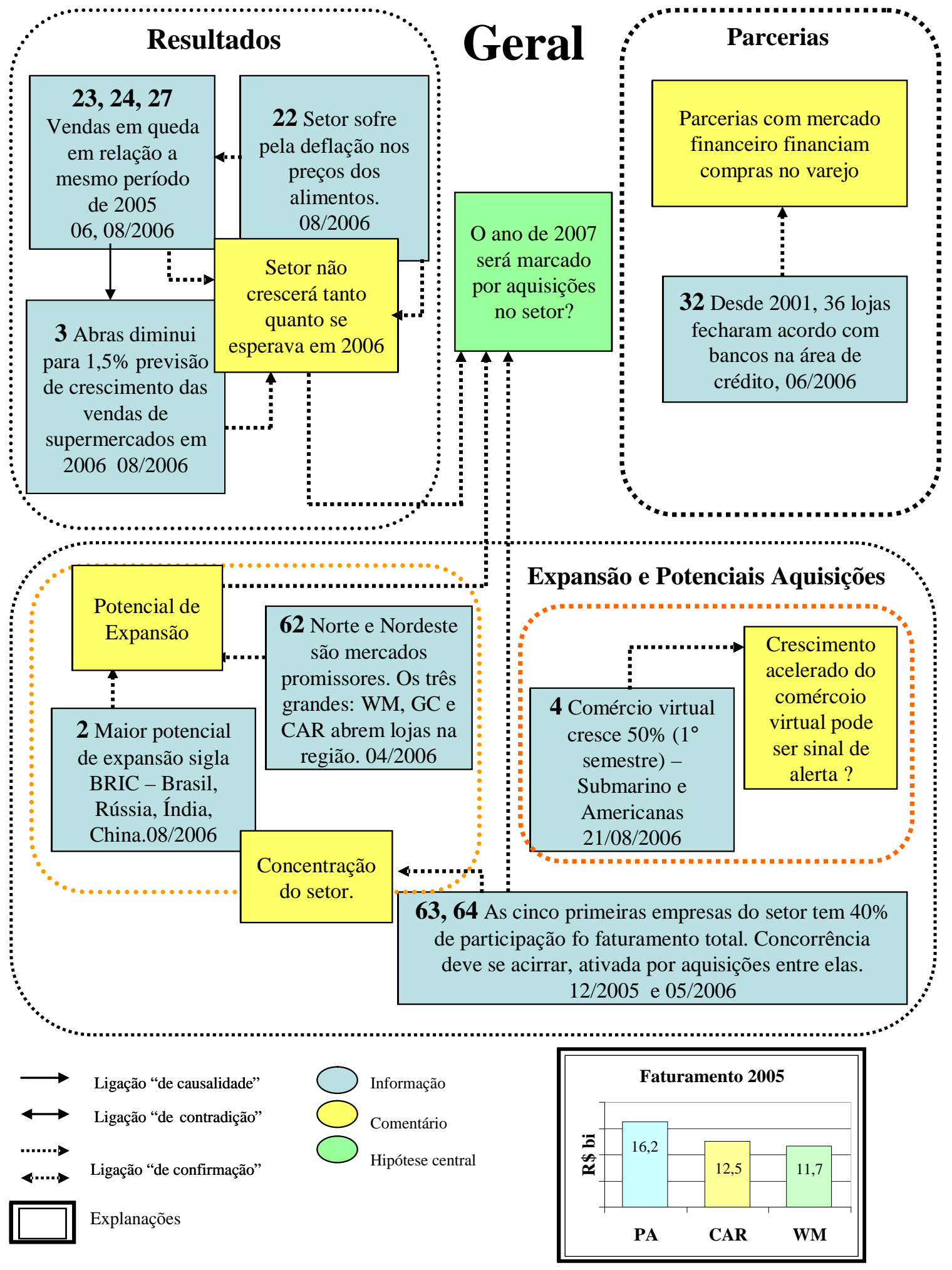

Ilustração 32 - Puzzle geral sobre o mercado supermercadista 
O puzzle identificado como Ilustração 28 trata de aspectos gerais do setor supermercadista. Existe uma alta concentração no faturamento do setor. As 3 primeiras empresas detêm, em termos percentuais de faturamento, $38 \%$ do total do setor. Pelo ranking ABRAS (Associação Brasileira de Supermercados) esses três são, por ordem de participação: CBD (Cia. Brasileira de Distribuição ou Pão de Açúcar), Carrefour e Wal-Mart.

O Grupo Pão de Açúcar fechou 2005 com 15\% de participação, o Carrefour com 11,8\%, com o Wal-Mart praticamente encostado, com $11 \%$.

Porém, mesmo entre os primeiros colocados, os resultados de 2006 não demonstram otimismo. A previsão de crescimento real para o ano, antes estimada pela Abras em alta de $2 \%$ a $2,5 \%$, foi revista e alterada para $1,5 \%$, devido ao fraco primeiro semestre, quando as vendas indicaram queda real de $2,74 \%$. No acumulado do ano até julho, o setor computou declínio de 2,83\% em relação ao mesmo período de 2006 (ValorOnline - 03/08/2006.).

Apesar do volume de vendas (em unidades) estar crescendo, o faturamento reduz-se, devido à deflação nos preços dos alimentos. Nos últimos 12 meses, os índices IPCA-Alimentos e o IPC-Alimentação da Fipe registraram deflação acumulada de 3,9\% e 3,4\%, respectivamente (ValorOnLine - 21/06/2006.).

Quando o assunto é expansão a unanimidade da mídia fica com duas frentes :

a) Os mercados da área de comércio varejista com maior potencial de crescimento nos próximos anos são os designados pela sigla BRIC - Brasil, Rússia, Índia e China.

b) No mercado brasileiro, as regiões mais promissoras são as do Norte e Nordeste, onde está a maior parte dos domicílios brasileiros e do consumo no País, 26\% e 27\%, respectivamente. Grandes redes, como Wal-Mart, que há dois anos adquiriu o Bompreço, a maior rede do Nordeste, o Carrefour e o Grupo Pão de Açúcar, abrem lojas nas duas regiões para fortalecerem suas presenças num mercado com alto potencial de expansão.

A ampliação da base de consumidores com acesso à internet permitem um crescimento considerado bastante expressivo e que deixa o atual mercado supermercadista em alerta, o do 
comércio eletrônico, com crescimento superior a 50\% no primeiro semestre, principalmente nas empresas de expansão acelerada, como o site Submarino ou Lojas Americanas, que extrai do braço virtual Americanas.com grande parte do seu faturamento. (ValorOnLine 21/08/2006.).

Para atacar a frente de redução de custos, o setor vem repassando o financiamento a seus clientes para o mercado financeiro, através de parcerias com bancos. O Pão de Açúcar tem um modelo desse tipo com o Itaú, e o Magazine Luiza, com o Unibanco. Bradesco e a rede de varejo G. Barbosa fizeram uma aliança. O Unibanco, com o Wal-Mart, trouxe para São Paulo o cartão HiperCard e o Cetelem tem convênio com o Carrefour (ValorOnLine - 21/08/2006.). 


\section{CONCLUSÕES}

No resumo inicial deste trabalho foram introduzidas algumas questões relativas ao tratamento de informações estratégicas para as organizações e as dificuldades de obtê-las, transformá-las em sinais antecipativos que possam representar um quadro onde fragmentos tornam-se um cenário com sentido mais concreto, desafiando executivos a tomarem decisões, mas com maior visibilidade e menor incerteza. A captação e tratamento destes tipos de sinais representam o campo de estudo da Inteligência Competitiva ou do Monitoramento Estratégico.

Autores afirmam, evidenciado na referência bibliográfica, que um ambiente onde essas informações estão cada vez mais sendo disponibilizadas e pesquisadas é o da Web. Tratandose de ambiente que se torna cada vez mais utilizado, inserido ou não em contexto acadêmico, empresarial ou simplesmente de uso popular ainda é praticamente impossível mantê-lo focado e ordenado de forma a facilitar a pesquisa de seu usuário.

Portanto, o objetivo deste trabalho foi explorar a Web como fonte principal destes sinais antecipativos. Hoje, é grande a quantidade de informações armazenadas e que são passíveis de serem recuperadas. É ainda maior o número de páginas que não conseguimos acessar seus conteúdos e que somente com programas de tecnologia mais apropriada para busca de informação, ou melhor, de formação de conhecimento, poderiam ser disponibilizados.

Para o trabalho com estas informações, foram executadas as etapas de rastreamento de sinais potencias, com um foco definido, a pré-análise destes sinais e formações de sentido com as informações obtidas através dos puzzles criados. É fundamental lembrar que o monitoramento estratégico é um processo contínuo, com visões sendo possivelmente alteradas, adicionadas ou eliminadas constantemente dos cenários para tomada de decisão. As informações tratadas neste trabalho foram rastreadas estaticamente, em uma só data, para cada fonte de informação.

A decisão para desenvolvimento da pesquisa foi pela utilização do método desenvolvido por Humbert Lesca (2003), descrito na referência bibliográfica.

Como a Web é um mundo ainda pouco padronizado e com uma quantidade de informações 
brutal a serem disponibilizadas em uma pesquisa específica, o objetivo foi também a construção de um protótipo de programa computacional, baseado no conceito de agentes inteligentes de software que facilitou a fase de rastreamento inicial, dentro de um foco de maior precisão.

O foco é definido pelo tema, atores e fontes de pesquisa. O tema escolhido foi referente a aquisição, fusão, compra e venda de bandeiras entre supermercados no mercado brasileiro. Outros temas coletados, que surgiram durante a pesquisa e que deveriam ser inclusos neste tipo de pesquisa, foram fundamentais para análise dos sinais antecipativos. Estes temas dizem respeito:

a) Resultados das empresas, para estudarmos potencial de aquisição dos envolvidos;

b) A expansão orgânica que aponta para direções além das inicialmente definidas de aquisições e fusões.

Como o foco engloba atores que podem ser pessoas jurídicas ou físicas e que sejam de interesse do pesquisador, foram escolhidos para serem trabalhados os maiores supermercados com atuação no mercado brasileiro, mais precisamente Pão de Açúcar, Carrefour e Wal-Mart. Esta escolha pareceu bastante adequada, já que a mídia trata estes grupos como os preferenciais de suas publicações e os três representam 38\% do market share do setor.

Durante o processo de rastreamente de informações surgiu um ator, que não era inicialmente foco da pesquisa, a rede Atacadão. O fato é que esta rede estava, no momento da pesquisa, em processo justamente de aquisição e envolvendo os atores definidos inicialmente como foco. Este caso foi fundamental para o entendimento deste tipo de processo, como o adiamento possível do processo de aquisição em caso de dúvidas de dívidas fiscais e trabalhistas, adequação de tipo de cultura e formatos de lojas.

Para fontes com acesso via Web foram selecionadas algumas de atuação generalista como Valor Econômico, Folha de São Paulo, O Estado de São Paulo e fontes especializadas como a ABRASNET da ABRAS (Associação Brasileira de Supermercados), a APAS (Associação Paulista de Supermercados) e PROVAR (Programa de Administração de Varejo). 
Definido o foco da pesquisa, o passo seguinte foi o de formalizar a visão abstrata de agentes com o objetivo de auxiliar a aprendizagem de como construir agentes para o caso do modelo de pesquisa a ser desenvolvido. Uma das arquiteturas sugeridas por Wooldridge (2002) é a procedural. Portanto, esta foi a forma de representação no modelo de pesquisa proposto.

O modelo foi baseado em um conjunto de iterações de busca na Web por links bons (aqueles que permitem acesso e que não representem perigo para o ambiente). Cada rodada de um agente denominado Ver verificava se já existia um repositório de links visitados e bons ou links visitados ruins, criava-os em caso negativo ou em caso positivo, gravava um link bom para futura pesquisa de interesse em atores e temas escolhidos ou gravava um link ruim que não seria utilizado para busca futura. A cada rodada, o agente de Indexação verificava se o link encontrado no ambiente já fora visitado anteriormente, para que a pesquisa não se tornasse infinita.

O agente denominado Busca requisitava uma query com palavras chave a serem rastreadas no repositório de links bons, que designavam os temas e atores especificados anteriormente, e a partir do endereço (URL) de uma fonte escolhida, buscava páginas que tratavam do tema e atores desejados. O produto do processo foi um conjunto de páginas WEB selecionadas que obedeciam ao objetivo especificado através de Temas, Atores e Fonte.

A análise era executada a cada endereço de página WEB (URL) encontrada, manualmente pelo pesquisador, verificando se a informação contida na página poderia ser proveitosa para a formação de sinais antecipativos.

Para o desenvolvimento de um programa com a utilização de agentes de software pode-se utilizar ferramentas específicas, que facilitam seu desenvolvimento e implementação, na maior parte das vezes escritas na linguagem Java, ou desenvolver-se em Java diretamente. Esta segunda opção foi a utilizada.

Quando estava em curso a pesquisa por mecanismos que facilitassem essa criação, foram encontrados programas que eram pontos de partida factíveis e que ajudaram muito para acelerar a construção do protótipo. Com algumas alterações, estes programas viabilizaram a indexação (etapa necessária para início de uma pesquisa na web, responsável pela transformação de formatos diferentes em formatos legíveis em etapa seguinte) e busca a partir 
de termos pré-definidos.

Utilizado pelas primeiras vezes, a etapa de indexação chegava a levar, dependendo da fonte especificada, até dois dias para ser finalizada. Um dado importante é que o ambiente de hardware utilizado era um microcomputador com processador Intel, Pentium 4, CPU de 3.20 GHz e 496 Mb de RAM, com ambiente de software Microsoft Windows XP Home Edition Versão 2002, Service Pack 2. O acesso à Internet era através de conexão de banda larga de velocidade 10,0 Mbps. Esta é uma configuração de microcomputador de uso pessoal, mais simples da que pode ser utilizada em muitas organizações, principalmente no que se refere ao acesso de redes através de banda larga, um fator fundamental para quem está utilizando a Web.

Para otimizar este processo, algumas melhorias foram necessárias como, por exemplo, a utilização de stopwords (palavras utilizadas comumente na linguagem e que não são necessárias para busca de termos específicos) como, por exemplo: a, o, de, até, portanto, todavia, contudo, mesmo, se, algum, alguma, senão, e tantas outras. Quando eliminadas pelo programa na fase de indexação elas chegam a reduzir seu processamento em até metade do tempo inicial.

A construção e utilização deste programa foram essenciais para o conhecimento do ambiente que já é hoje o grande repositório de informações necessárias para o Monitoramento Estratégico de ambiente de uma organização. Caso a pesquisa não seja bem definida e o foco restringido, pode ser impraticável trabalhar com a quantidade de informações recuperadas.

Além disso, foi fundamental a percepção de que sites diferentes são construídos diferentemente, sem nenhum padrão pré-definido. Pesquisar no site da Folha de São Paulo, que ao final da página mantém um link para páginas com assuntos semelhantes é completamente diferente de pesquisar no site do Valor Econômico, que mantém um frame fixo nas suas páginas (mas com informações que se alteram durante o dia, como o valor do dólar, por exemplo) e no seu corpo exibe as páginas que foram pesquisadas.

Uma das conclusões mais importante deste processo foi que o rastreador profissional de uma organização precisa conhecer como estes sites são construídos e até como os criadores de informação, na maioria das vezes jornalistas ou pesquisadores, tem suas próprias visões dos 
assuntos tratados. Seja do geral para o específico, seja do específico para o geral.

Estes problemas de diferenças em como sites e informações são construídos e armazenados devem ser solucionados gradativamente à medida que padrões sejam estabelecidos.

A busca por padronização de formatação e ordenação dessas informações representa um desafio para pesquisadores da área de conhecimento e tecnologia, baseado em padrões como, por exemplo, o da Web Semântica ${ }^{2}$.

Na construção do protótipo levou-se em conta o que é opinião de vários autores, pesquisados para este trabalho, que o melhor método para a recuperação de informação na Web é através da tecnologia de Agentes Inteligentes. A estrutura desse ambiente é muito similar à forma como agentes e agências são estruturados, facilitando a forma de indexação e busca focada em atores, temas e fontes definidos por usuários do conceito de sinais antecipativos, ou seja, do monitoramento estratégico de uma organização.

Essa semelhança ficou evidente à medida que o desenho da aplicação, baseado em agentes e agências, e a pesquisa por informações através do protótipo foram sendo desenvolvidos e aplicados na pesquisa por potenciais sinais antecipativos.

O formato utilizado no ambiente da Web, com utilização de hyperlinks ${ }^{3}$, é o tipo de formato em que agentes inteligentes conseguem agir, levando em conta as capacidades de reação (agentes inteligentes são capazes de perceber seu ambiente, responder com um comportamento adequado à situação e fazer intervenções em tempo necessário para que satisfaçam seus objetivos definidos), pró-atividade (agentes inteligentes são capazes de dirigir-se a uma meta tendo a iniciativa de satisfazer seus objetivos pré-definidos) e habilidade social (agentes inteligentes são capazes de interagir com outros agentes em ordem de satisfazer seus objetivos definidos).

\footnotetext{
${ }^{2}$ A Web Semântica é um projeto dirigido por Tim Berners-Lee, criador do HTML e da World Wide Web sob a coordenação do W3C (World Wide Web Consortium) com o objetivo de melhorar as potencialidades da Web através da criação de ferramentas e de padrões que permitam atribuir significados claros aos conteúdos das páginas e facilitar a sua publicação e manutenção. As páginas construídas usando a filosofia da Web Semântica passam a fazer parte de um meio universal para a troca de informação. (Extraído do site http://www.artifice.web.pt/redir.htmïtpag=00/web-design/02-11-2004-web-semantica.htmi em 26/09/2006.).
}

3 Hyperlink é uma referência ou elemento de navegação em um documento para outra seção do mesmo documento, outro documento ou para uma seção específica de outro documento que, automaticamente traz a informação referida. 
Para a finalidade deste trabalho foram utilizados programas diretamente escritos em linguagem Java, utilizando-se bibliotecas de classes e métodos de domínio público.

Esses programas que percorrem a Web indexando seu conteúdo inicialmente e depois buscando informações de interesse do usuário, normalmente através de palavras-chave, são denominados Web Crawler ou Web Spider ${ }^{4}$. Estes foram utilizados para a construção do protótipo e são utilizados na maioria dos mecanismos de busca, como o Google ${ }^{\circledR}$.

Após a coleta de informações através do protótipo foram feitas as mesmas pesquisas utilizando o mecanismo de busca do produto hoje mais disseminado, o Google ${ }^{\odot}$. A finalidade desta comparação foi a identificação de possíveis disparidades e a análise delas para alterações e melhorias do protótipo criado, avaliar e discutir a adequação dos sinais coletados por esse programa e se o conceito de agentes pode ou não ser utilizado de forma a recuperar informações para utilização em monitoramento estratégico de forma mais efetiva.

Com o rastreamento dessas informações, potenciais sinais antecipativos, foi iniciada a fase de pré-análise. Neste trabalho esta análise foi executada de forma manual pelo pesquisador, página a página, entre as recuperadas pelo programa de busca com as palavras-chave denominadas, constituindo atores e tema escolhidos, e as recuperadas pelo mecanismo de busca do Google ${ }^{\odot}$.

Várias dessas páginas foram eliminadas neste processo, seja pela data de publicação (somente foram selecionadas notícias do ano de 2006, com raríssimas exceções de notícias do ano de 2005), ou ainda pela irrelevância para o foco especificado. Uma tendência forte neste momento foi a de considerar a maior parte das informações como importantes. A construção do puzzle (quebra-cabeça) foi uma forma bastante eficaz de evidenciar que informações não significam nenhuma evidência antecipativa e que podem e devem ser excluídas do processo, tornando a visualização mais clara e com evidências mais bem retratadas.

Foram construídos puzzles para cada um dos atores definidos (Pão de Açúcar, Carrefour e

\footnotetext{
${ }^{4}$ Programa ou script automatizado que percorre a World Wide Web de uma forma metódica.
} 
Wal-Mart com suas outras bandeiras representadas) e, adicionalmente, um para tratar a questão do Atacadão, já que é assunto atual da mídia e o único processo de aquisição de supermercados em andamento até o momento de finalização desta pesquisa. Um puzzle (quebra-cabeça) final, com informações gerais sobre o mercado supermercadista foi elucidativo, como já descrito no item de comentários sobre os puzzles criados.

A experiência de construção de puzzles para formação de sentido foi um exercício precioso para a pesquisa no tratamento da informação, pois estimulou e motivou o pensamento sobre a validade de todo o processo de monitoramento estratégico na Web. O que consta na Web consta na mídia escrita ou em bases de conhecimento com acesso restrito. Como Lesca (2003) descreve, as fontes possíveis de informação são várias e incluem congressos, feiras, bases de patentes, informações de fornecedores e mesmo fontes informais.

Portanto, a complementação através de outras fontes poderia ter enriquecido os resultados encontrados na Web mas, ratificando os autores citados na referência bibliográfica, a conclusão da pesquisa é que a Web reúne a maior parte das informações necessárias para o tipo de monitoramento que foi desenvolvido neste trabalho.

Muitas informações foram trabalhadas para a criação de várias versões dos puzzles. Eles foram sendo criados até que seus fragmentos, muitas vezes tratados por fontes, formas e em momentos diferentes, formaram cenários lógicos.

Finalmente, respondendo às questões iniciais:

a) a exploração da Web como fonte principal de sinais antecipativos ou sinais de alerta precoce para organizações - para a finalidade desta pesquisa, os conteúdos necessários foram encontrados nas fontes especificadas, todas com acesso via Web. Das que necessitavam de uma contratação especial, com acesso restrito a assinantes, somente não foi contratado o serviço de acesso ao Estado de São Paulo, para fins de comparação de conteúdo de um caso e de outro, e também pelo fato que já se conhecia de antemão que O Estado de São Paulo não foca o assunto aquisições e fusões como o periódico Valor Econômico, por exemplo. Realmente, as informações coletadas nesta fonte foram mínimas. A conclusão é que para se trabalhar com essas fontes de acesso limitado são necessárias as devidas contratações de assinaturas. Cada uma delas tem um tipo de 
requisição de senha em um formato diferente e em momentos diferentes no acesso a elas, o que muitas vezes pode levar à necessidade de tratamento específico para acesso a cada uma das fontes escolhidas. Importante citar que as fontes de pesquisa para o Monitoramento Estratégico não se esgotam na mídia, mas podem ser diversas, como contatos com fornecedores, congressos, conversas ocasionais, e outras. O objetivo do trabalho foi o foco do acesso aos sinais antecipativos via Web;

b) a utilização de agentes de software para a construção de ferramentas de acesso mostrouse totalmente adequado. Os acessos às páginas são perfeitamente representados por agências, subdivididas em agentes mas não de forma totalmente hierárquica, como representado por Minsky (1986). Os já descritos WebCrawlers ou WebSpiders são os mecanismos mais utilizados para percorrer estas páginas. O produto de mercado CISpider (Competitive Intelligence Spider), baseado em agentes inteligentes de software, parece ser o mais fácil de ser compreendido neste assunto. Como especificações iniciais permitidas ao usuário existem: o número de spiders que já são utilizadas no início da pesquisa abrindo caminhos diferenciados para percorrer (o que deve depender do harware que se dispõe e da forma de construção do site em questão) e até que nível alcançar em termos de profundidade da pesquisa. Parâmetros como esses parecem facilitar a forma como atuam agentes de software e precisariam ser adicionados ao protótipo para torná-lo mais eficiente, caso fosse de interesse a continuidade de sua utilização;

c) pesquisas utilizando o mecanismo de busca do produto de mercado hoje mais disseminado, o Google ${ }^{\odot}$ com a finalidade de identificar possíveis disparidades e a análise delas para alterações e melhorias do protótipo criado - um aspecto que causou surpresa foi o fato de que as notícias rastreadas no ValorOnLine (site do Valor Econômico) foram praticamente complementares, quando da comparação do rastreamento pelo protótipo e pelo Google ${ }^{\odot}$, diferentemente do site da Folha de São Paulo, por exemplo, com produtos praticamente idênticos. Não foi possível a identificação do porquê deste fato mas a única conclusão possível é a diferença, como já citada anteriormente, na forma como estes sites são construídos e na forma como cada programa percorre cada um deles. Enquanto não houver uma padronização na forma como as páginas da Web e seus conteúdos são armazenados, provavelmente o 
tratamento em cada tipo de negócio terá que ser tratado individualmente, como já atestado por Lafaye (2005). 


\section{TRABALHOS FUTUROS}

A implementação de um mecanismo de Monitoramento estratégico requer atenção a várias frentes ou dimensões de uma organização como:

- $\quad$ cultura organizacional, comportamento das pessoas envolvidas no processo, motivação e técnicas de aprendizagem. Na sua tese de doutorado, Lugo (2004) trata de redes sociais de agentes e comportamentos destes agentes para a formação de conhecimento. No item de trabalhos futuros, ele utiliza termos que abordariam muitas das questões acima levantadas quando se trata de comportamento e utilização de redes de aprendizagem em redes de pessoas: cooperação, conceitos de redes sociais, papéis sociais e ponto de vista de receptores de informações, acumulação de conhecimento e relação entre reputação e conhecimento.

No trabalho de Sukthankar e Sycara (2006) encontra-se o tratamento da questão de composição de times e o mapeamento de agentes como times e o reconhecimento destes em casos de composições dinâmicas. Composições de times são geralmente assumidas como estáticas. No caso de monitoramento estratégico, nem sempre os times mais eficientes são os formados inicialmente e, tratando-se do tema a ser rastreado, podem e muitas vezes são diferenciados. Formar times eficientes e motivados para a continuidade de aprendizagem através de sinais captados pode ditar a continuidade e sucesso da aplicação dos conceitos de Monitoramento.

- técnicas e ferramentas para recuperação da maior quantidade de informações qualificadas possível. Dutante o desenvolvimento desta pesquisa ficou evidente que a fase de um ciclo de Monitoramento Estratégico que exige maior esforço e tempo dos profissionais da informação é a de rastreamento e filtro. Agrupá-las e classificá-las é uma forma de reduzir este esforço. A recuperação de conteúdo de dados em forma textual implica na importância de extrair e interpretar conteúdo semântico em um domínio específico. O objetivo de facilitar a integração de informações de várias fontes (uma necessidade na formação de sentido em dados textuais fragmentados) pode ser alcançado com a utilização do conhecimento semântico extraído de um texto através de ontologias. Os grupos de termos ou palavras que formam uma ontologia podem ser 
aprendidos e armazenados especificamente para uma organização.

Existem formas diferentes de tratamento de textos. Ankolekar et al (2003) citam que o conhecimento semântico de textos e ontologias trazem resultados mais aprofundados do que métodos baseados em estatística convencional, utilizadores do conceito de clustering $^{5}$ ou de teoria das probabilidades como as baseadas no teorema de Bayes ${ }^{6}$. Este é um tema de estudo merecedor para quem necessita escolher um software de prática do Monitoramento Estratégico Competitivo.

- $\quad$ fechando o ciclo, trata-se a forma de disseminação que pode transformar uma decisão parcial em realidade, contando com o estímulo da organização em geral. O conhecimento formado por informações agrupadas em cenários com sentido deve transformar-se em decisão, ser questionado ou descartado. O conhecimento parcial precisa ser partilhado com a organização. Formas de tratar conhecimento é estudo da área de Gestão do Conhecimento e que necessitam estudo específico para a utilização na área em questão.

\footnotetext{
5 Técnica de agrupamento utilizada já há vários anos em dados quantitativos, e agora em pesquisa para aprimoramento de sua utilização em textos.

${ }^{6}$ Teorema de Bayes é uma fórmula matemática simples usada para cálculo de probabilidades condicionais. (extraído deihttp://plato.stanford.edu/entries/bayes-theorem// em 26/09/2006.).
} 


\section{REFERÊNCIAS}

AGUILAR, Francis J. Scanning the Business Environment. NY, New York: MacMillan, 1967.

ALTER, Steven L. Information Systems: a management perspective. Canada: Cummings Publishing Company Inc., 1996.

ALTER, Steven L. A general, yet useful theory of information systems, Communications of Association for Information Systems, v.1, article 13, p.1-70, 1999.

ANSOFF, Igor. Managing Strategic Surprise by Response to Weak Signals, California Management Review, v.18, n.2, p.21-33, 1975.

BELLMAN, Richard E. An introduction to Artificial Intelligence: Can Computers Think?. San Francisco: Boyd \& Fraser Publishing Company, 1978.

BLANCO, Sylvie.; CARON-FASAN, Marie-Laurence.; LESCA, Humbert. Developing Capabilities to Create Intelligence within Organizations. Journal of Competitive Intelligence and Management, v. 1, n. 1,p.80-92, Spring 2003.

CHARNIAK, Eugene; MCDERMOTT, Drew. Introduction to Artificial Intelligence. Massachusetts: Addison-Wesley, Reading, 1985.

CHEN, Hsinchun; CHAU, Michael; ZENG, Daniel. CI Spider: a tool for competitive intelligence on the Web. Decision Support Systems, n.34, p. 1-17. Elsevier Science, 2002.

$\mathrm{CHOO}$, Chun Wei. Information Management for the Intelligent Organizations: the art of Scanning the environment. Medford: ASIS Monograph Series, Information Today Inc., 2002.

DANIELS, Kevin; JOHNSON, Gerry; DE CHERNATONY, Leslie. Task and institutional influences on managers' mental models of competitions. Organizational Studies, v.23, n.1, p.31-62, 2002.

DECKER, Reinhold; WAGNER Ralf; SCHOZ, Sören. An Internet-based approach to environmental scanning in marketing research. Marketing Intelligence \& Planning, v. 23, n. 2; p. 189; ABI/INFORM Global, 2005.

FAHEY, Liam. Analysing the Competition. Business Blindspots, Chicago: Probus Publishing Company, 1993.

HAUGELAND, John. Artificial Intelligence: The Very Idea. Cambridge, Massachusetts: MIT Press, 1985. 
HEATON, Jeff. (2002). Programming a Spider in Java. Extraído em maio de 2006. do site: 'http://Www.developer.com/java/other/article.php/1573761'.

HEWITT, Carl E. Offices are open systems. ACM Transactions on Office Information Systems, v.4, n.3, p.271-287, 1986.

HILTUNEN, Elina. Weak Signals. Paper presented at the seminar on Scenario Building. Turku, available at:http://Web.tukkk.fi/tutu/vanhat/Scemesepapers/ElinaHiltunen.pdfil ., 2001.

HODGKINSON, G.P. Cognitive Intertia in a turbulent market: the case of UK residential estate agents. Journal of Management studies, v.34, n.6, p.921-45, 1997.

ILMOLA, Leena.; AALTONEN, Mika.; AUTIO, ERKKO. Weak signal filters in vision building processes. In: Annual International Conference of the Strategic Management Society, $22^{\text {nd }}$, Paris, 2002.

JANSEN, James. Using an Intelligent Agent to Enhance Search Engine Performance. Disponível em: http://www.firstmonday.dk/issues/issue 2 3/jansen/index.htm>i . Acesso em: jan. 2002.

KURZWEILL, Ray. The Age of Intelligent Machines. Cambridge, Massachusetts: MIT Press, 1990.

LAFAYE, Christophe. Agents Intelligents pour la phase de traque d'un processus de veille stratégique et trajectories d'appropriation organisationelle : une approche exploratoire. Chercheur Equipe Modeme, Université Jean Moulin LYON 3. XIV ${ }^{\text {ième }}$ Conference Internationale de Management Strategique, Pays de La Loire, Angers 2005. Disponível em: hittp://Www.strategie-aims.com/.

LESCA, Humbert. Veille stratégique : la méthode L.E.SCAnning® . Ed. ems, 194 p, 2003.

LESCA Humbert; CASTAGNOS, Jean-Claude. Signaux faibles et méthode Cible : quelques retours d'expérience. Colloque AIMS Montpellier, 2000.

LIU, Shuhua. Strategic scanning and interpretation revisiting: foundations for a software agent support system - Part 1: understanding the concept and context of strategic scanning. Industrial Management \& Data Systems, 98/7, p. 295-312, 1998.

LIU, Shuhua. Strategic scanning and interpretation revisiting: foundations for a software agent support system - Part 2: scanning the business environment with software agents. Industrial Management \& Data Systems, 98/8, p. 362-372, 1998.

LUGO, Gustavo A. G.. Um modelo de Sistemas Multiagentes para Partilha de Conhecimento Utilizando Redes Sociais Comunitárias. Tese apresentada à Escola Politécnica da Universidade de São Paulo para obtenção do Título de Doutor em Engenharia, 2004. 
MACMULLIN, Susan; TAYLOR, Robert. Problem Dimensions and Information Traits. Information Society 3, $n^{\circ} 1$ :91-111, 1984.

MARTINET, Alain Charles. Management Stratégique: organization et politique. Paris: Mc Grawhill, 1984.

McALLESTER, David A. What is the most pressing issue facing AI and the AAAI today? Candidate statement, election for Councilor of the American Association for Artificial Intelligence, 1998.

MILES, Raymond E.; SNOW, Charles C. Organizational Strategy, Structure, and Process. New York, NY:McGraw-Hill, 1978.

MINSKY, Marvin. The Society of Mind. New York, NY: Simon \& Schuster Inc, , 1986.

MINSKY, Marvin. Commonsense-Based Interfaces. Communications of the ACM, August, v.43, n.9, 2000.

MINTZBERG, Henry. The Nature of Managerial Work. New York, NY: Harper \& Row, 1973.

MOHAMMADIAN, Masoud et al. Intelligent Agents for Data Mining and Information Retrieval. IDEA Group Publishing, 2004.

MOSTAFA, Javed. Seeking Better Web Searches. Scientific American, fev. 2005.

NONAKA, Ikujiro; TAKEUCHI, Hirotaka. Criação de Conhecimento na Empresa: como as Empresas japonesas geram a dinâmica da inovação. Rio de janeiro: Campus, 1997.

POOLE, David; MACKWORTH, Alan; GOEBEL, Randy. Computational Intelligence: A logical approach. Oxford, UK: Oxford University Press, 1998.

PORTER, Michael E.. Competitive Strategy: Techniques for Analyzing Industries and Competitors. New York, NY: The Free Press, 1980.

PRESCOTT, John.E.; MILLER, Stephen H. Inteligência competitiva na prática. Rio de Janeiro: Campus, 2002.

REGER, Rhonda; PALMER, Timothy. Managerial categorization of competitors: using old maps to navigate new environments. Organizational Science, v.7, n.1, p.22-39, 1996.

RIECKEN, Doug. A conversation with Marvin Minsky. Communications of the ACM, v.37, n.7, p.23-29, July, 1994.

ROEDEL, Daniel; STAREC, Cláudio (Org.). Gestão Estratégica da Informação e Inteligência Competitiva. São Paulo, SP: Editora Saraiva, 2005. 
RUSSEL, Stuart; NORVIG, Peter. Artificial Intelligence, a modern approach. Prentice Hall Series in Artificial Intelligence, 2003.

ANKOLEKAR, Anupriya; SEO, Young-Woo; SYCARA, Katia. Investigating Semantic Knowledge for Text Learning. Robotics Institute, Carnegie Mellon University, 2003.

SUKTHANKAR, Gita; SYCARA, Katia. Simultaneous Team Assignment and Behavior Recognition from Spatio-temporal Agent Traces. American Association for Arificial Intelligence, 2006.

WEISS, Gerhard et al. Multiagent Systems, a modern approach to Distributed Artificial Intelligence. Massachusetts Institute of Technology, 1999.

WINSTON, Patrick Henry. Artificial Intelligence. $3^{\text {rd }}$ ed.. Addition-Wesley, Reading, Massachusetts, 1992.

WOOLDRIDGE, Michael. An introduction to Multiagent System. Southern Gate, Chichester, West Sussex, PO19 8SQ, England: John Wiley \& Sons, Ltd, 2002.

WOOLDRIDGE, Michael; JENNINGS, Nick. Intelligent Agents: Theory and Practice. Knowledge Engineering Review, v.10, n.2, p.115-152, 2003.

ZWICKER, Ronaldo. Material de aula do curso Informática na Administração da FEA Administração de Empresas, 2005. 


\section{ANEXOS}

\section{ANEXO 1 - Resultados das informações rastreadas.}

\section{1}

\begin{tabular}{|c|c|c|}
\hline \multicolumn{3}{|c|}{ À espera de um novo dono, Atacadão abre quatro lojas } \\
\hline Fonte & Data de Publicação & Data de Rastreamento \\
\hline Valor OnLine & \multirow[t]{2}{*}{$15 / 08 / 2006$} & $26 / 08 / 2006$ \\
\hline \multicolumn{2}{|c|}{ Informação Essencial } & \\
\hline \multicolumn{3}{|c|}{$\begin{array}{l}\text { Em meio à segunda tentativa de mudar de dono, o Atacadão decidiu reforçar os investimentos em expansão. } \\
\text { Apenas este ano, o grupo paulista vai abrir quatro novas lojas - todas em imóveis próprios - no Nordeste e em } \\
\text { São Paulo. O investimento, que inclui a compra do terreno, construção do imóvel, equipamentos e estoque } \\
\text { inicial, soma em média R } \$ 50 \text { milhões por unidade. Até o fim do ano, o grupo terá } 34 \text { lojas em oito capitais. }\end{array}$} \\
\hline \multicolumn{3}{|c|}{ Análise da Informação } \\
\hline \multicolumn{3}{|c|}{$\begin{array}{l}\text { Atacadão esta abrindo quatro novas lojas, em meio à negociação de aquisição de suas loja } \\
\text { pelo Pão de Açúcar, Carrefour ou Wal-Mart. }\end{array}$} \\
\hline \multicolumn{3}{|c|}{ Processo está sendo postergado. } \\
\hline \multirow[t]{2}{*}{ Temas } & & Atores \\
\hline & & Atacadão, WM, PA, CAR \\
\hline
\end{tabular}


2

\begin{tabular}{|c|c|c|}
\hline \multicolumn{3}{|c|}{ A produção puxa os lucros e traz mais ânimo para investir } \\
\hline Fonte & Data de Publicação & Data de Rastreamento \\
\hline Valor OnLine & 15/08/2006 & 26/08/2006 \\
\hline \multicolumn{3}{|c|}{ Informação Essencial } \\
\hline \multicolumn{3}{|c|}{$\begin{array}{l}\text { Pelos lados do Wal-Mart, maior rede de comércio varejista do mundo, até há pouco o grupo estava ainda } \\
\text { adequando seu modelo de gestão à realidade brasileira. Mas em } 2006 \text { começará a mostrar mais as garras. } \\
\text { Segundo Wilson Mello Neto, vice-presidente de assuntos corporativos, o Brasil é um país estratégico para o } \\
\text { Wal-Mart. Os mercados da área de comércio varejista com maior potencial de expansão e crescimento nos } \\
\text { próximos tempos são os designados pela sigla BRIC - Brasil, Rússia, Índia e China. "Em } 2006 \text { vamos investir } \\
\text { R } 600 \text { milhões na abertura de } 15 \text { lojas, o que vai gerar mais de } 5 \text { mil empregos", afirma. }\end{array}$} \\
\hline \multicolumn{3}{|c|}{ Análise da Informação } \\
\hline \multicolumn{3}{|c|}{$\begin{array}{l}\text { Os mercados da área de comércio varejista com maior potencial de expansão e crescimento } \\
\text { nos próximos tempos são os designados pela sigla BRIC - Brasil, Rússia, Índia e China. WM } \\
\text { vai investir } R \$ 600 \text { milhóes na abertura de } 15 \text { lojas em } 2006 \text {. }\end{array}$} \\
\hline \multirow[t]{2}{*}{ Temas } & & \multirow{2}{*}{\begin{tabular}{|l|} 
Atores \\
WM. M. Supermercadista \\
\end{tabular}} \\
\hline & & \\
\hline
\end{tabular}


3

\begin{tabular}{|l|l|}
\hline \multicolumn{3}{|c|}{ Abras diminui para 1,5\% previsão de crescimento das vendas de } \\
Supermercados em 2006
\end{tabular}


4

\section{Avanço do comércio virtual e crédito ditam indicações no varejo}

\begin{tabular}{|l|c|c|}
\hline Fonte & Data de Publicação & Data de Rastreamento \\
\hline ValorOnLine & $\mathbf{2 1 / 0 8 / 2 0 0 6}$ & $\mathbf{2 9 / 0 8 / 2 0 0 6}$ \\
\hline Informação Essencial & & \\
\hline A & &
\end{tabular}

A união dos bancos com as redes varejistas e a ampliação da base de consumidores com acesso à internet são as duas frentes de crescimento do setor de varejo no Brasil, ainda com pouca representação na Bolsa de Valores de São Paulo. Entre as opções existentes, os analistas apostam principalmente nas empresas de expansão acelerada, que atuam na área de comércio eletrônico, como o site Submarino ou Lojas Americanas, que extrai do braço virtual Americanas.com grande parte do seu faturamento.

Pela base de dados da Thomson One Analytics, 6 entre 9 analistas têm recomendação de compra para as ações preferenciais (PN, sem direito a voto) da Lojas Americanas, com a média de preço alvo em $\mathrm{R} \$ 103,25$, um potencial de valorização de mais de $18 \%$ considerando-se a atual cotação na bolsa. Dos 8 analistas que cobrem Submarino, 7 indicam a aquisição do papel, com um preço estimado em R \$ 59,95, 36\% acima do fechamento de ontem.

"O comércio eletrônico cresceu quase $50 \%$ no primeiro semestre e as duas empresas (Submarino e Americanas.com) tiveram uma expansão até acima disso, mostrando que ganharam mercado", diz o analista da Fator Corretora Marcio Kawassaki. "O varejo virtual foi especialmente beneficiado pelo bom desempenho dos eletroeletrônicos, com a venda de produtos de maior tíquete médio, enquanto a área de alimentos - que representa $70 \%$ do mix de vendas do Pão de Açúcar - ficou comprometida por endividamentos de longo prazo em bens duráveis e semi-duráveis."

Submarino é o papel considerado "top pick" (com alto potencial de valorização num curto espaço de tempo)..... expansão da rede de banda larga no Brasil, que deve agregar mais consumidores à internet rápida, e na estratégia da companhia de crescer por meio de aquisições. "A intenção é diversificar ao máximo o ... como ocorreu com a Ingresso.com e a Travel Web."

\section{Comentários}

A união dos bancos com as redes varejistas e a ampliação da base de consumidores com acesso à internet são as duas frentes de crescimento do setor de varejo no Brasil. o comércio eletrônico cresceu quase $50 \%$ no primeiro semestr, com Submarino e Americanas acima disso.

Temas

Atores

PA, Submarino, Americanas

URL da fonte

iwww.valoronline com br/... /Avanco+do+comercio+virtual +e+credito+ditam+indicacoes+no+t varejo, ,49,3849707. html 


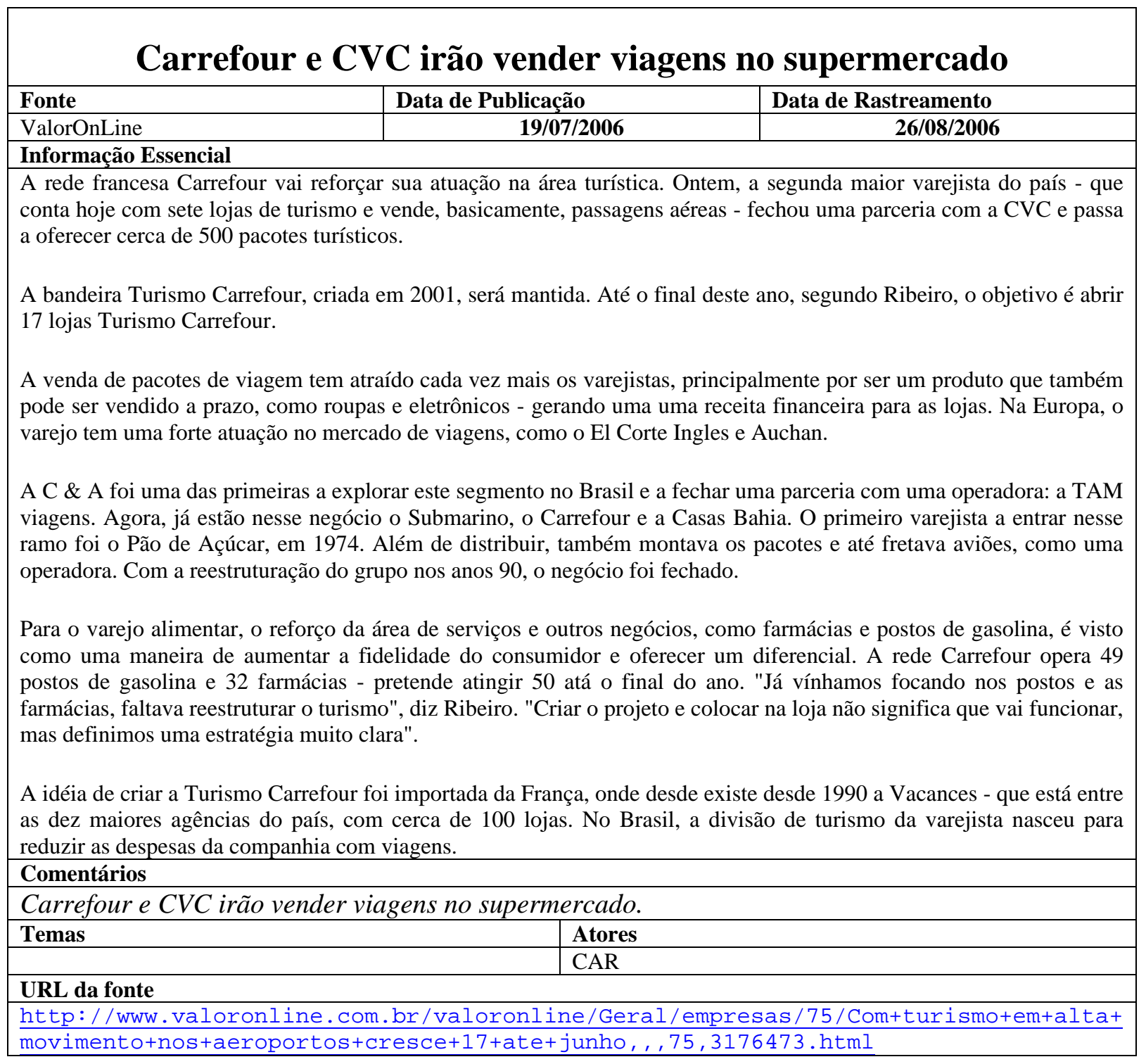




\section{6}

\begin{tabular}{|c|c|c|}
\hline \multicolumn{3}{|c|}{ Casa em ordem e expansão } \\
\hline Fonte & Data de Publicação & Data de Rastreamento \\
\hline Valor OnLine & Início 2006 & $26 / 08 / 2006$ \\
\hline \multicolumn{3}{|c|}{ Informação Essencial } \\
\hline \multicolumn{3}{|c|}{$\begin{array}{l}\text { Depois de adquirir a nordestina Bompreço e ser considerado o virtual comprador da rede de supermercados do } \\
\text { Sonae no Brasil, o Wal-Mart nem precisava acenar com outros investimentos para ser o destaque de crescimento } \\
\text { entre os grandes grupos comerciais. Mesmo assim, o gigante norte-americano abriu dez lojas em } 2005 \text { e } \\
\text { anunciou um agressivo plano de expansão orgânica para } 2006 \text {. Serão gastos R } \$ 600 \text { milhões na inauguração de } \\
15 \text { novos pontos comerciais. "Queremos chegar a todos os lugares, estar acessíveis a todos os clientes, utilizando } \\
\text { uma estratégia de multiformatos", diz Wilson Mello Neto, vice-presidente de assuntos corporativos da Wal-Mart } \\
\text { Brasil. } \\
\text { Para enfrentar o grupo em ascensão, o líder Pão de Açúcar conta com um passado de guinadas surpreendentes - }- \\
\text { incluindo a recente capitalização de mais de } \$ \$ 1 \text { bilhão, obtida com o aporte do sócio Casino. Além de reduzi } \\
\text { o endividamento líquido da empresa, a operação viabilizou um plano de investimentos de aproximadamente } \$ \\
2,5 \text { bilhões na abertura de } 160 \text { novas lojas (120 supermercados e } 40 \text { hipermercados) nos próximos quatro anos, } \\
\text { segundo Fernando Tracanella, diretor de relações com investidores da holding Companhia Brasileira de } \\
\text { Distribuição (CBD). }\end{array}$} \\
\hline \multicolumn{3}{|c|}{ Análise da Informação } \\
\hline \multicolumn{3}{|c|}{$\begin{array}{l}\text { WM é destaque de crescimento entre os grandes grupos comerciais, apontando para } \\
\text { crescimento orgânico durante } 2006 R \$ 600 \mathrm{mi}) \text {, com a estratégia de multiformatos. } O \text { Pão de } \\
\text { Açúcar capitalizou-se com o aporte do Casino }(R \$ 1 \text { bi). }\end{array}$} \\
\hline \multirow[t]{2}{*}{ Temas } & & Atores \\
\hline & \\
\hline
\end{tabular}




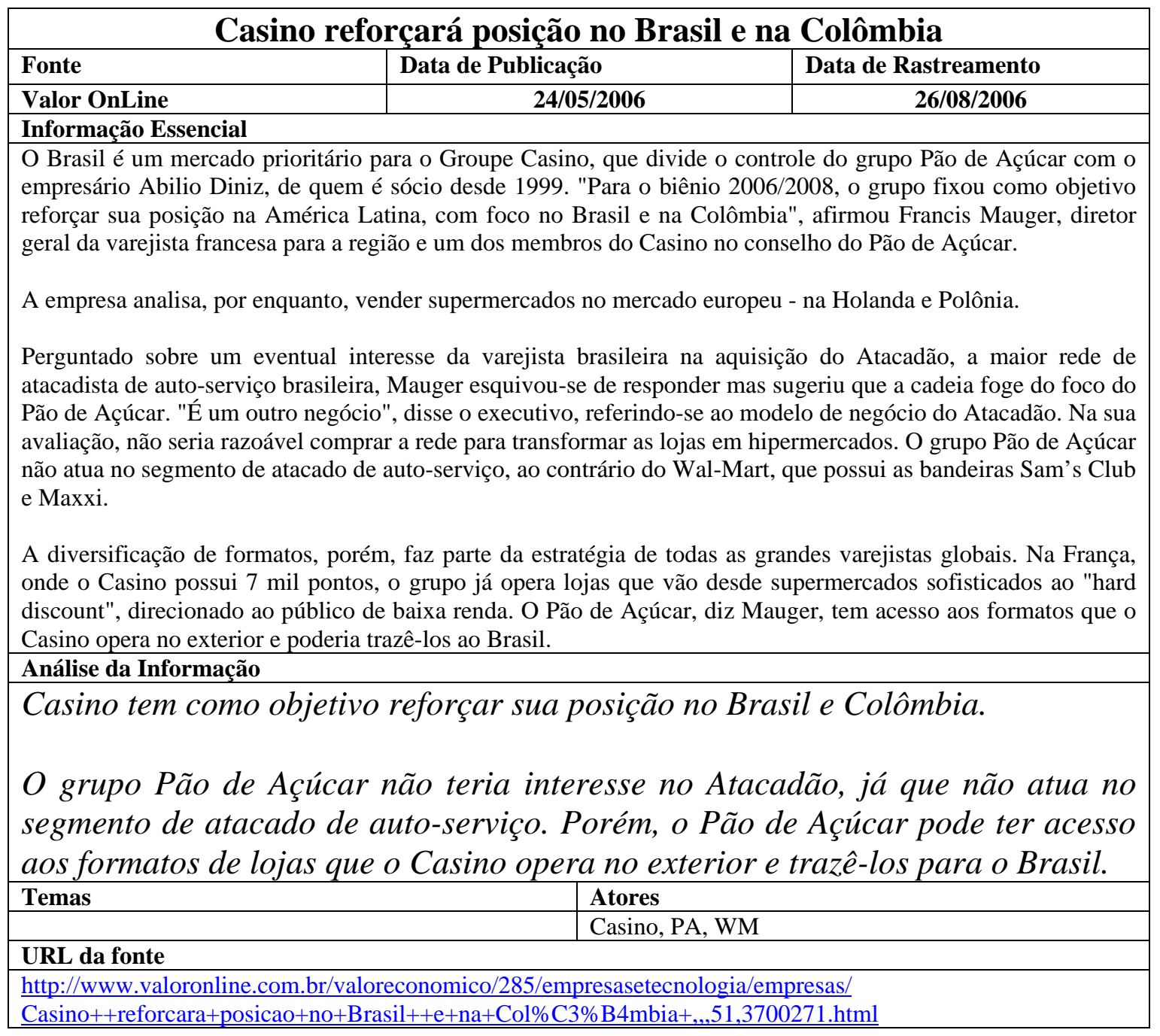


8

\section{Com 149 lojas, Unisuper avança em direção a Santa Catarina e Paraná}

\begin{tabular}{|l|c|c|}
\hline Fonte & Data de Publicação & Data de Rastreamento \\
\hline ValorOnLine & $21 / 08 / 2006$ & $15 / 08 / 2006$ \\
\hline
\end{tabular}

\section{Informação Essencial}

Criada em outubro de 2000, a União Gaúcha de Supermercados (Unisuper), uma central de negócios que desde a fundação ampliou o número de empresas associadas de 14 para 96 e de lojas, de 23 para 149, prepara-se para avançar fora do Rio Grande do Sul. A rede já está negociando a filiação dos primeiros varejistas de Santa Catarina e no segundo semestre do ano que vem a expansão deve chegar ao Paraná.......o avanço da Unisuper é uma resposta à crescente concentração do setor supermercadista, que aumentou com a aquisição das operações da portuguesa Sonae no Brasil pela americana Wal-Mart. Ele estima que até o fim de 2007 a central incorpore mais 100 lojas, sendo pelo menos 50 em Santa Catarina. Em 2008 o número total deve chegar a 400, incluindo no mínimo outras 50 unidades no Paraná.

"Já temos consultas de supermercadistas do Rio de Janeiro e de São Paulo", afirma Silva. Mas, segundo ele, a caminhada para além das fronteiras da região Sul do país é uma etapa que ainda não tem data prevista.

A Unisuper é a quarta maior central de compras no ranking da Associação Brasileira de Supermercados (Abras) relativa a 2004 (os dados de 2005 serão divulgados em setembro). Naquele ano a rede contava com 73 empresas e 120 lojas e faturou R \$ 501,2 milhões, atrás da Arcos, de São Paulo (R \$ 660 milhões), da Avaes, do Espírito Santo (R \$ 594,9 milhões) e da Rede Valor, de Minas Gerais (R \$ 565 milhões).

Segundo Silva, neste ano a central gaúcha deve faturar R \$ 700 milhões, ante R \$ 575 milhões em 2005 (mais do que os $\mathrm{R} \$ 496,1$ milhões faturados pelo $15^{\circ}$ maior supermercado do país, o baiano Ebal) e já projeta vendas de R\$ 1 bilhão em 2007. "Estamos trabalhando para assumir a liderança nacional no segmento", diz. Em Porto Alegre, o centro de distribuição fica na Ceasa, a central de abastecimento ligada à Secretaria da Agricultura do Estado.

Além das compras conjuntas, que garantem custos de $10 \%$ a $30 \%$ menores para os associados, especialmente nas linhas de produtos de limpeza, bazar e perfumaria, os associados da Unisuper compartilham identidade visual, organização das lojas, propaganda, 235 itens de marca própria, serviços contábeis e tributários por um custo mensal "simbólico", diz Silva.

\section{Comentários}

Com 149 lojas, Unisuper avança em direção a Santa Catarina e Paraná. Neste ano deve faturar $R \$ 700$ milhões

\begin{tabular}{|l|l|}
\hline Temas & Atores \\
\hline URL da fonte & Unisuper \\
\hline \multicolumn{2}{|l|}{} \\
\hline
\end{tabular}




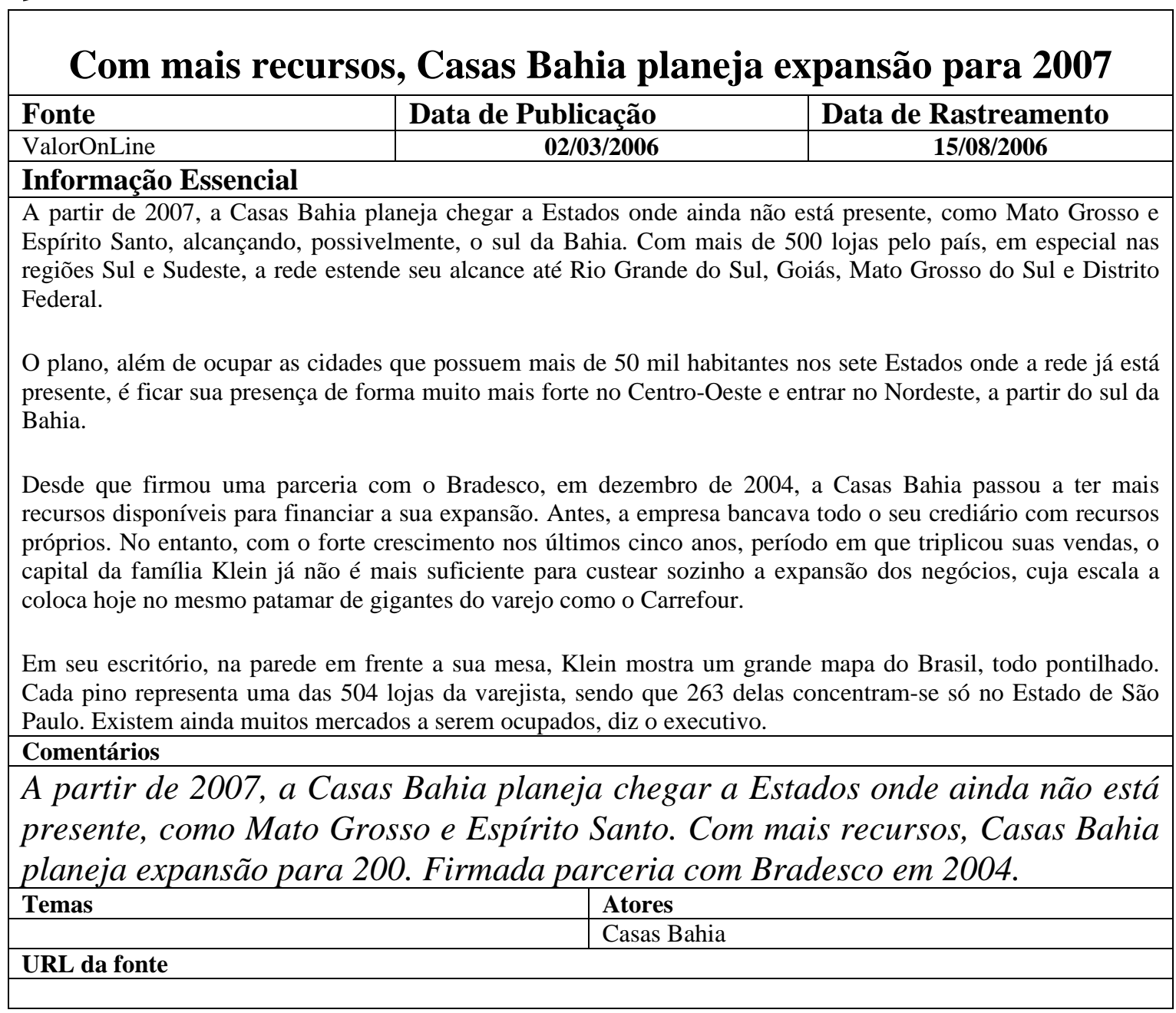




\section{Consumo aumenta, mas faturamento dos supermercados diminui com preços mais baixos}

\begin{tabular}{|l|c|c|}
\hline Fonte & Data de Publicação & Data de Rastreamento \\
\hline ValorOnLine & $\mathbf{0 3 / 0 8 / 2 0 0 6}$ & $\mathbf{2 6 / 0 8 / 2 0 0 6}$ \\
\hline Informação Essencial & \\
\hline O consumo nos supermercados cresce, mas o setor vem apresentando sucessivas perdas de faturamento devido à \\
forte queda nos preços dos produtos. Hoje, a Associação Brasileira dos Supermercados (Abras) reafirmou que as \\
vendas reais do setor, que já acumulam baixa de 2,74\% de janeiro a junho, têm como principal justificativa a \\
diminuição dos preços.
\end{tabular}

"Há um descompasso muito grande entre as vendas físicas e o faturamento", afirmou o presidente da Abras, João Carlos Oliveira. Segundo ele, os dados mais recentes sobre as vendas físicas, referentes ao primeiro quadrimestre deste ano, mostram um aumento de $3,5 \%$. No mesmo intervalo de tempo, o faturamento acumulou queda de $2,53 \%$ em termos reais.

"As pessoas compram produtos mais baratos. A fidelidade à marca está em segundo plano atualmente. Além disso, os preços têm sido sistematicamente reduzidos por causa da concorrência", explicou o dirigente.

A queda dos preços pode ser observada na pesquisa da própria Abras, feita quinzenalmente nos supermercados brasileiros com um conjunto de 35 produtos de alto consumo. A chamada Cesta ABRASMercado registrou queda real de 7,11\% em junho, na comparação com o mesmo mês de 2005.

A redução mais significativa de preços acontece no grupo de Alimentos. Considerando os primeiros seis meses do ano, a pesquisa da Abras mostra que o frango congelado teve queda de 21,23\%. O preço do leite em pó integral declinou $11,06 \%$ e a carne caiu 7,7\% (traseiro). As maiores quedas percentuais ocorreram entre produtos mais afetados por safra, como a batata, que caiu $32,74 \%$, e o tomate, que apontou redução de $44,16 \%$ nos preços nesse mesmo período.

Comentários

Consumo aumenta, mas faturamento dos supermercados diminui com preços mais baixos. A redução mais significativa de preços acontece no grupo de Alimentos. A chamada Cesta ABRASMercado registrou queda real de 7,11\% em junho, na comparação com o mesmo mês de 2005.

\begin{tabular}{l|l} 
Temas & Atores \\
\hline
\end{tabular}

http://www. valoronline. com br//valoronline/Geral/empresas/37/Consumo +aumenta+mas+faturamento dos+supermercados+diminui+com+precos+mais+baixos, , $37,3823784 . \mathrm{html}$ 


\section{1}

\begin{tabular}{|c|c|c|}
\hline \multicolumn{3}{|c|}{ Despesa com venda de operações diminui lucro trimestral da Wal-Mart } \\
\hline Fonte & Data de Publicação & Data de Rastreamento \\
\hline Valor OnLine & $15 / 08 / 2006$ & $26 / 08 / 2006$ \\
\hline \multicolumn{3}{|c|}{ Informação Essencial } \\
\hline \multicolumn{3}{|c|}{$\begin{array}{l}\text { A Wal-Mart fechou os três meses até } 31 \text { de julho com vendas líquidas totais de US\$ } 84,524 \text { bilhões, com alta de } \\
11,3 \% \text { em relação ao segundo trimestre fiscal do exercício anterior. O lucro líquido, porém, ficou em US } \$ 2,083 \\
\text { bilhões - } 25,7 \% \text { menor do que os US } \$ 2,805 \text { bilhões do mesmo período do calendário passado. } \\
\text { A queda no lucro foi relacionada à venda de suas operações na Alemanha. } \\
\text { Durante o trimestre, a varejista desfez-se de suas atividades na Coréia do Sul e na Alemanha, agora } \\
\text { contabilizadas como descontinuadas. }\end{array}$} \\
\hline \multicolumn{3}{|c|}{ Análise da Informação } \\
\hline \multicolumn{3}{|c|}{ WM encerra atividades na Coréia do Sul e Alemanha. } \\
\hline \multirow[t]{2}{*}{ Temas } & & Atores \\
\hline & WM & \\
\hline
\end{tabular}




\section{Eletrônicos garantem crescimento de $2,6 \%$ nas vendas de mesmas lojas do Pão de Açúcar em junho}

\begin{tabular}{|l|c|c|}
\hline Fonte & Data de Publicação & Data de Rastreamento \\
\hline ValorOnLine & $\mathbf{1 3 / 0 7 / 2 0 0 6}$ & $\mathbf{2 6 / 0 8 / 2 0 0 6}$ \\
\hline
\end{tabular}

\section{Informação Essencial}

Enquanto as vendas de produtos alimentícios continuam com desempenho negativo ante o mesmo mês do ano anterior, a categoria de eletrônicos garantiu que o grupo Pão de Açúcar (Cia. Brasileira de Distribuição - CBD) tivesse uma elevação de 2,6\% nas vendas do mês de junho, no conceito de mesmas lojas, em comparação com período correspondente de 2005 .

De acordo com comunicado distribuído pela companhia, o desempenho foi resultado "da boa performance apresentada pela categoria não-alimentos", de $24,2 \%$, puxada principalmente por eletrônicos, além de uma "ligeira recuperação" em relação aos meses anteriores das vendas de produtos alimentícios, que ainda foram $3,8 \%$ menores por causa do impacto do câmbio e da deflação nos preços de alguns itens.

As vendas brutas do grupo no mês passado foram de R\$ 1,25 bilhão, com incremento de 3,6\% sobre junho de 2005 , enquanto as vendas líquidas foram de $\mathrm{R} \$ 1,05$ bilhão, montante 4,4\% superior ante intervalo semelhante do ano anterior.

Em todo o segundo trimestre, as vendas brutas da companhia somaram R \$ 3,97 bilhões, cifra 4,9\% maior que no ano passado. Já a receita líquida foi de $\mathrm{R} \$ 3,33$ bilhões entre abril e junho, com crescimento de 5,6\% em relação ao mesmo intervalo de 2005. No trimestre, as vendas no conceito de mesmas lojas cresceram 2,5\%.

Comentários

Vendas de produtos alimentícios continuam com desempenho negativo. Eletrônicos garantem crescimento de 2,6\% nas vendas de mesmas lojas do Pão de Açúcar em junho

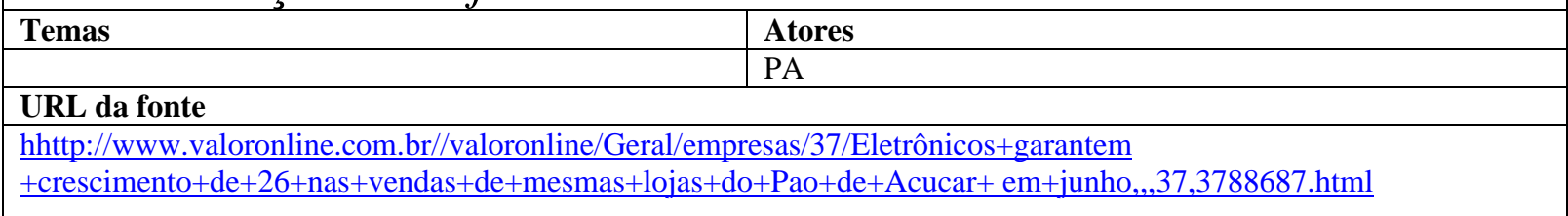


13

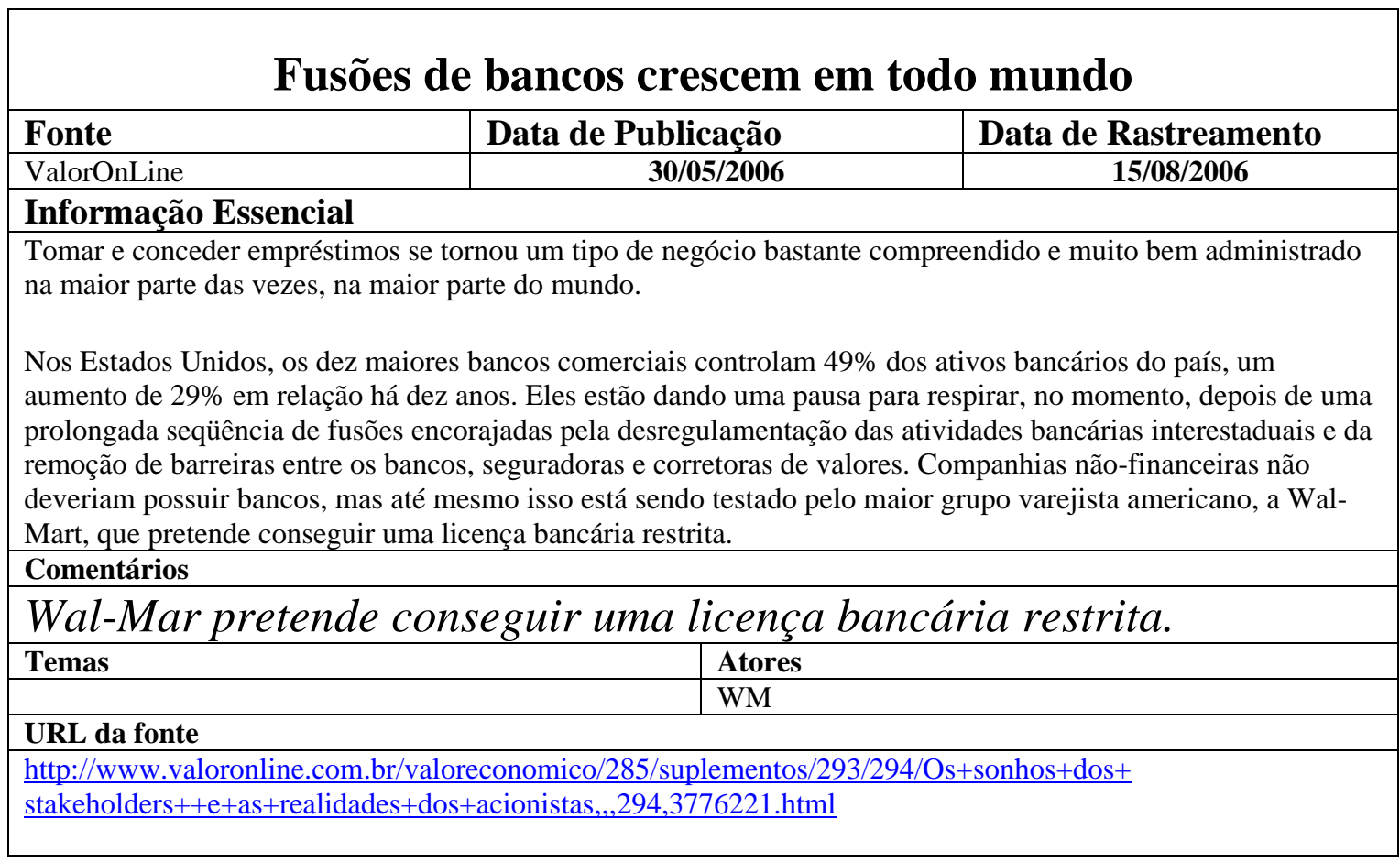




\section{Lojas Wal-Mart há um ano em funcionamento têm vendas 2,7\% maiores em agosto}

\begin{tabular}{|c|c|c|}
\hline Fonte & Data de Publicação & Data de Rastreamento \\
\hline ValorOnLine & $31 / 08 / 2006$ & 15/08/2006 \\
\hline \multicolumn{3}{|c|}{ Informação Essencial } \\
\hline \multicolumn{3}{|c|}{$\begin{array}{l}\text { As lojas da Wal-Mart abertas há pelo menos um ano nos Estados Unidos apresentaram aumento de } 2,7 \% \text { nas } \\
\text { vendas em agosto. A previsão da companhia era de uma elevação de } 1 \% \text { a } 3 \% \text { no faturamento, projeção essa } \\
\text { mantida para o próximo mês. }\end{array}$} \\
\hline \multicolumn{3}{|c|}{$\begin{array}{l}\text { "Vimos um ímpeto nas vendas de agosto. Nossos clientes concentraram suas compras em itens como alimentos e } \\
\text { produtos para a volta às aulas", disse o diretor-financeiro da varejista, Tom Schoewe. } \\
\text { As vendas totais de agosto somaram US\$ } 25,965 \text { bilhões, acima dos US } \$ 23,072 \text { bilhões registrados um ano } \\
\text { antes. }\end{array}$} \\
\hline \multicolumn{3}{|c|}{ Os dados constam de comunicado da própria empresa. } \\
\hline \multicolumn{3}{|l|}{ Comentários } \\
\hline \multicolumn{3}{|c|}{$\begin{array}{l}\text { lojas da Wal-Mart abertas há pelo menos um ano nos Estados Unidos } \\
\text { apresentaram aumento de } 2,7 \% \text { nas vendas em agosto }\end{array}$} \\
\hline \multirow[t]{2}{*}{ Temas } & Atore: & \\
\hline & WM & \\
\hline L da font & & \\
\hline
\end{tabular}




\begin{tabular}{|c|c|c|}
\hline \multicolumn{3}{|c|}{ Os sonhos dos stakeholders e as realidades dos acionistas } \\
\hline Fonte & Data de Publicação & Data de Rastreamento \\
\hline ValorOnLine & \multirow{2}{*}{$06 / 07 / 2006$} & 15/08/2006 \\
\hline \multicolumn{2}{|c|}{ Informação Essencial } & \\
\hline \multicolumn{3}{|c|}{$\begin{array}{l}\text { Nos Últimos meses, o choque entre os interesses de acionistas e de stakeholders (as partes interessadas na empresa, } \\
\text { como governo, organizações não-governamentais, clientes e fornecedores) esteve no centro das batalhas entre as } \\
\text { empresas em toda a Europa. }\end{array}$} \\
\hline \multicolumn{3}{|c|}{$\begin{array}{l}\text { Nos Últimos } 25 \text { anos, os Estados Unidos têm pressionado as empresas a utilizar o conceito de retorno aos } \\
\text { acionistas. O Reino Unido já mostra uma boa aceitação do conceito e ele vai se espalhando pela Europa continental } \\
\text { e o mundo. Mas as empresas enfrentam uma pressão contrária no sentido de atender às reivindicações de outros } \\
\text { stakeholders, que vão além do mero tratamento justo dos funcionários, do cumprimento das leis e das doações para } \\
\text { instituições de caridade. }\end{array}$} \\
\hline \multicolumn{3}{|c|}{$\begin{array}{l}\text { A Gap e a Nike têm sido atacadas por explorar o trabalho infantil no subcontinente indiano. A Coca-Cola, a Kraft e } \\
\text { outras empresas dos setores de alimentos e de bebidas vêm sendo acusadas de contribuir para a obesidade infantil } \\
\text { no mundo em desenvolvimento. }\end{array}$} \\
\hline \multicolumn{3}{|c|}{$\begin{array}{l}\text { É fundamental que as empresas reconheçam a importância do chamado "triple bottom line". Isso exige que, além } \\
\text { das contas financeiras, as empresas também mantenham contas sociais e contas ambientais para saber como estão } \\
\text { atendendo às reivindicações da sociedade e às questões ambientais. }\end{array}$} \\
\hline \multicolumn{3}{|c|}{$\begin{array}{l}\text { Toda empresa que deixa de reconhecer essas reivindicações corre o risco de ter sua reputação chamuscada. A Shell } \\
\text { descobriu isso com o caso Brent Spar; a McDonald’s vem sendo questionada sobre o conteúdo de seus } \\
\text { hambúrgueres; e a Wal-Mart enfrenta uma avalanche de acusações, desde a exploração de funcionários até o } \\
\text { esfacelamento da tradição norte-americana das pequenas lojas de comércio. }\end{array}$} \\
\hline \multicolumn{3}{|c|}{$\begin{array}{l}\text { O indício, por menor que seja, de que a reputação de uma empresa possa ser afetada influencia o preço de suas } \\
\text { ações. Afinal, os acionistas conhecem o poder de pressão dos consumidores, desde os boicotes até a publicidade } \\
\text { negativa. Por outro lado, reconhecer essas reivindicações tem feito bem aos negócios. A Starbucks, que no passado } \\
\text { era acusada de causar a falência das pequenas empresas, hoje faz questão de enfatizar suas credenciais de } \\
\text { praticante do comércio justo. Vamos aguardar o primeiro relatório sobre sustentabilidade da Wal-Mart, prometido } \\
\text { para } 2007 \text {. }\end{array}$} \\
\hline \multicolumn{3}{|c|}{ Comentários } \\
\hline \multicolumn{3}{|c|}{$\begin{array}{l}\text { Wal-Mart enfrenta uma avalanche de acusações, desde a exploração de } \\
\text { funcionários até o esfacelamento da tradição norte-americana das } \\
\text { pequenas lojas de comércio. Espera-se o primeiro relatório sobre } \\
\text { sustentabilidade da Wal-Mart, prometido para } 2007 .\end{array}$} \\
\hline Temas & Atore & \\
\hline \multicolumn{3}{|c|}{$\begin{array}{l}\text { URL da fonte } \\
\text { acww. valoronline.com.bristas } 1,294,3776221 \text { html }\end{array}$} \\
\hline
\end{tabular}


16

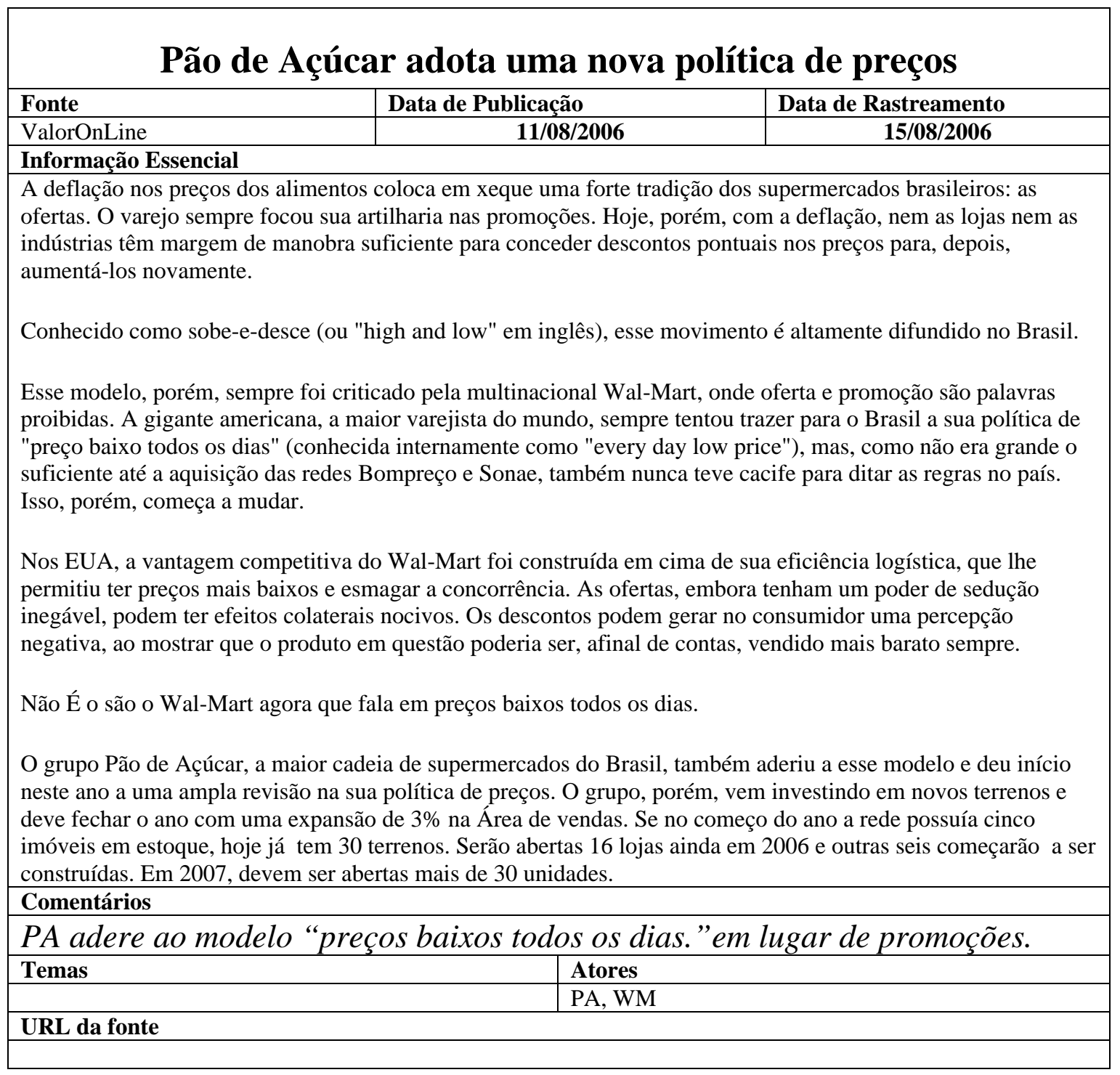




\section{7}

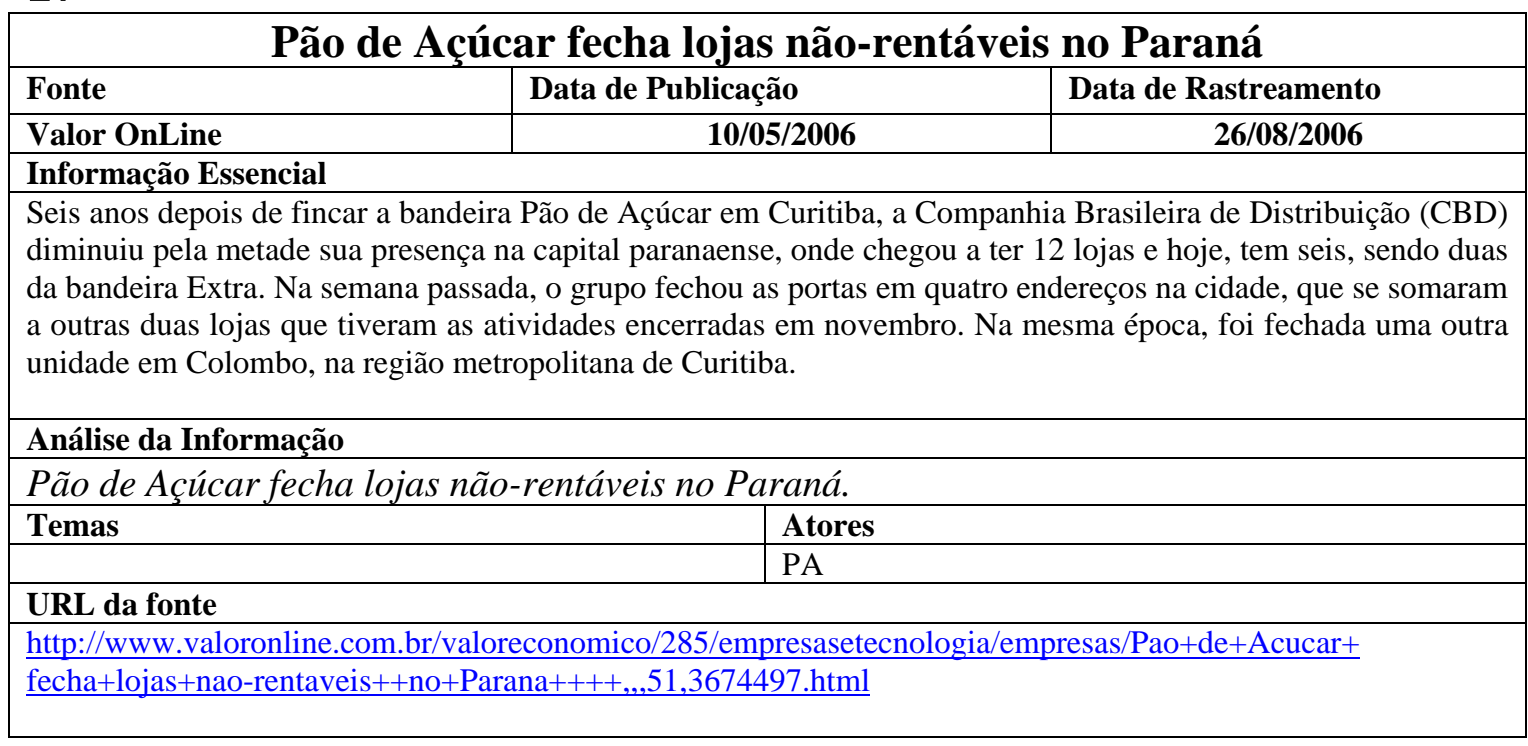


18

\begin{tabular}{|c|c|c|}
\hline \multicolumn{3}{|c|}{ Persistência e paciência na rota das aquisições } \\
\hline Fonte & Data de Publicação & Data de Rastreamento \\
\hline Valor OnLine & 20/08/2006 & $26 / 08 / 2006$ \\
\hline \multicolumn{3}{|c|}{ Informação Essencial } \\
\hline \multicolumn{3}{|c|}{$\begin{array}{l}\text { Em menos de dois anos o Wal-Mart no Brasil foi responsável pelo desembolso de nada menos do que US\$ } 1 \\
\text { bilhão em aquisições. A multinacional americana pagou US\$ } 300 \text { milhões pela rede de supermercados } \\
\text { Bompreço, adquirida em março de } 2004 \text {. As lojas do Sonae, líder na região Sul, foram compradas em dezembro } \\
\text { de } 2005 \text {, por US } \$ 750 \text { milhões. } \\
\text { Daqui para frente, prevêem analistas, o Wal-Mart irá brigar pela liderança, seja por meio de novas compras ou } \\
\text { com a construção de seus próprios hipermercados. } \\
\text { Neste ano, serão investidos cerca de R } \$ 600 \text { milhões na abertura de } 15 \text { hipermercados. No ano passado, foram } \\
\text { desembolsados R } \$ 450 \text { milhões na construção de nove lojas. }\end{array}$} \\
\hline \multicolumn{3}{|c|}{$\begin{array}{l}\text { Com um faturamento em torno de } \mathrm{R} \$ 2,5 \text { bilhões por ano, as operações brasileiras eram modestas para o setor e } \\
\text { não faziam jus ao gigantismo da corporação, a maior do mundo, cujas vendas alcançaram US } \$ 300 \text { bilhões em } \\
2005 .\end{array}$} \\
\hline \multicolumn{3}{|c|}{$\begin{array}{l}\text { "Com o Bompreço, estávamos assumindo uma empresa com vendas anuais de } \mathrm{R} \$ 3,5 \text { bilhões, bem maior do que } \\
\text { nós éramos na época. Não podíamos falhar na aquisição." }\end{array}$} \\
\hline \multicolumn{3}{|c|}{$\begin{array}{l}\text { Na história, há vários casos de aquisições fracassadas e poucos de sucesso. Suas concorrentes, como o grupo } \\
\text { português Sonae, cujos ativos o Wal-Mart viria a adquirir, enfrentaram duras penas para integrar as redes } \\
\text { compradas no mercado brasileiro. O Carrefour fechou vários dos supermercados adquiridos nos anos } 90 . \text { O } \\
\text { próprio Wal_Mart passou por momentos amargos com suas aquisições no Reino Unido e na Alemanha. }\end{array}$} \\
\hline \multicolumn{3}{|c|}{$\begin{array}{l}\text { Trius mostrou que estava preparado para dar o salto que seria o divisor de águas para o Wal-Mart no Brasil. Os } \\
\text { resultados com o Bompreço ficaram muito acima das metas estabelecidas pelo grupo em 2004. Em 2005, o } \\
\text { sucesso repetiu-se. Trius conseguiu, enfim, encontrar a rota para o sucesso das aquisições. Hoje, o processo de } \\
\text { incorporação do Bompreço é considerado pelo Wal-Mart como uma de suas melhores práticas administrativas no } \\
\text { mundo. }\end{array}$} \\
\hline \multicolumn{3}{|c|}{ Análise da Informação } \\
\hline \multicolumn{3}{|c|}{$\begin{array}{l}\text { Em menos de dois anos o WM desembolsou US\$ } 1 \text { bilhão em aquisições e irá brigar pela } \\
\text { liderança. Neste ano serão investidos } R \$ 600 \text { bilhões na abertura de } 15 \text { hipermercados. }\end{array}$} \\
\hline \multirow[t]{2}{*}{ Temas } & & \\
\hline & & \\
\hline \multicolumn{3}{|l|}{ RL da fonte } \\
\hline & & \\
\hline
\end{tabular}




\begin{tabular}{|l|}
\hline \multicolumn{2}{|c|}{ Preços menores prejudicaram faturamento dos supermercados } \\
em maio, diz Abras
\end{tabular}


20

\section{Ranking da Abras mostra disputa acirrada entre Carrefour e Wal-Mart}

\begin{tabular}{|l|c|c|}
\hline Fonte & Data de Publicação & Data de Rastreamento \\
\hline ValorOnLine & $\mathbf{2 6 / 0 4 / 2 0 0 6}$ & $\mathbf{0 7 / 0 8 / 2 0 0 6}$ \\
\hline Informação Essencial & & \\
\hline
\end{tabular}

\section{Informação Essencial}

As redes de supermercados Carrefour e Wal-Mart devem travar um batalha acirrada para aumentar a participação de mercado e disputar o segundo lugar no ranking do setor. Conforme dados divulgados hoje pela Associação Brasileira de Supermercados (Abras) a rede francesa sustentou a segunda posição no ranking de 2005, com $11,8 \%$ da fatia de mercado - pouco acima dos $11 \%$ conquistados pelo Wal-Mart após a aquisição da rede portuguesa Sonae, no ano passado.

Considerando o levantamento feito em 2004, quando a participação do Carrefour era de 12,4\%, com faturamento de $\mathrm{R} \$ 12,1$ bilhões, houve diminuição de seis pontos percentuais na fatia mercado, embora o faturamento tenha crescido para R \$ 12,546 bilhões. Já o Wal-Mart elevou sua participação de 6,2\% para $11 \%$ em 2005, com faturamento de R \$ 11,7 bilhões. Essa expansão é justificada pela aquisição da rede Sonae, que em 2004 ocupava o quarto lugar do ranking, com $4,4 \%$ da fatia do setor.

De qualquer modo, as duas concorrentes estão bem distantes do resultado alcançado pela Companhia Brasileira de Distribuição, dona da rede Pão de Açúcar, que fechou 2005 mais uma vez na liderança, com participação de $15,2 \%$ do mercado (abaixo dos 15,8\% em 2004) e faturamento de $\mathrm{R} \$ 16,169$ bilhões.

O Carrefour preferiu não se pronunciar sobre o ranking, mas o Wal-Mart comemorou o resultado de 2005 anunciando que prevê investimentos da ordem de R \$ 600 milhões para abertura de 15 novas lojas neste ano, maior número de unidades abertas em um ano desde que a rede se instalou no Brasil, em 1995.

Comentários

Disputa acirrada entre Carrefour e Wal-Mart, justificada pela aquisição da rede Sonae.

Temas

URL da fonte
Atores

PA, CAR, WM 


\begin{tabular}{|c|c|c|}
\hline \multicolumn{3}{|c|}{ Rede Smart, criada pelo Martins, já fatura perto de $\mathbf{R} \$ 3$ bilhões } \\
\hline Fonte & Data de Publicação & Data de Rastreamento \\
\hline Valor OnLine & \multirow[t]{2}{*}{ 23/05/2006 } & $26 /$ \\
\hline \multicolumn{2}{|c|}{ Informação Essencial } & \\
\hline \multicolumn{3}{|c|}{$\begin{array}{l}\text { A rede Smart - uma bandeira de supermercados que foi desenvolvida pelo Martins no ano } 2000 \text { como uma } \\
\text { ferramenta para fidelizar os pequenos comerciantes - já se transformou em um negócio tão grande quanto o } \\
\text { próprio grupo atacadista mineiro, o maior distribuidor do país. Com } 801 \text { lojas espalhadas atualmente por } 10 \\
\text { Estados, o "sistema" Smart já fatura algo em torno de R } \$ 3 \text { bilhões por ano. Em } 2005 \text {, as vendas do grupo } \\
\text { Martins totalizaram } R \$ 2,7 \text { bilhões. } \\
\text { O avanço da rede mostra que os formatos conhecidos no setor como "hard discount" e "soft discount" estão se } \\
\text { fortalecendo. Essas pequenas lojas de bairro, direcionadas para as classes C, D e E, estão encontrando espaço } \\
\text { para crescer apesar da maior concentração do setor nas mãos de três grandes cadeias - Pão de Açúcar, Carrefour } \\
\text { e Wal-Mart. } \\
\text { Normalmente, nossos associados são supermercados que possuem um faturamento médio mensal em torno de R } \$ \\
300 \text { mil ", afirma Fábio Batista, diretor de gestão da Rede Smart. } \\
\text { O grupo Martins criou a bandeira Smart com a intenção de ajudar seus clientes a enfrentar as grandes cadeias de } \\
\text { supermercados. Ao aderir à marca, o que pode ser feito sem que o supermercadista tenha de desistir de seu } \\
\text { nome, os pequenos comerciantes ganham escala e conseguem diluir custos. } \\
\text { Com a bandeira Smart, o grupo atacadista no sistema de entrega conseguiu ainda uma outra vantagem. A } \\
\text { empresa colocou um pé no varejo, protegendo assim a sua clientela do assédio dos atacadistas de auto-serviço, } \\
\text { que possuem uma rede de lojas. } \\
\text { A disputa neste mercado acirrou-se com o avanço de grandes empresas, como o Atacadão, o Makro e o Wal- } \\
\text { Mart, que possui duas bandeiras de atacado, o Sam "s Club e o Maxxi, rede comprada do Sonae na região Sul. } \\
\text { O mercado de baixa renda vem atraindo cada vez mais a atenção das grandes varejistas. O Carrefour, por } \\
\text { exemplo, deslanchou em São Paulo a bandeira Dia\%, modelo de supermercados "hard discount" trazido da } \\
\text { Espanha. Mesmo o Wal-Mart está testando no Nordeste a bandeira Balaio, uma rede de pequenos supermercados } \\
\text { localizados em áreas pobres. }\end{array}$} \\
\hline \multicolumn{3}{|c|}{ Análise da Informação } \\
\hline \multicolumn{3}{|c|}{$\begin{array}{l}\text { Sinal de perigo potencial de crescimento acelerado de concorrente entre os primeiros } \\
\text { colocados do ranking supermercadista. }\end{array}$} \\
\hline \multirow[t]{2}{*}{ Temas } & & Atores \\
\hline \\
\hline & & \\
\hline \multicolumn{3}{|c|}{ hthtth://www.valoronline.com.br/valoronline/Geral/empresas/37.html? } \\
\hline
\end{tabular}




\section{2}

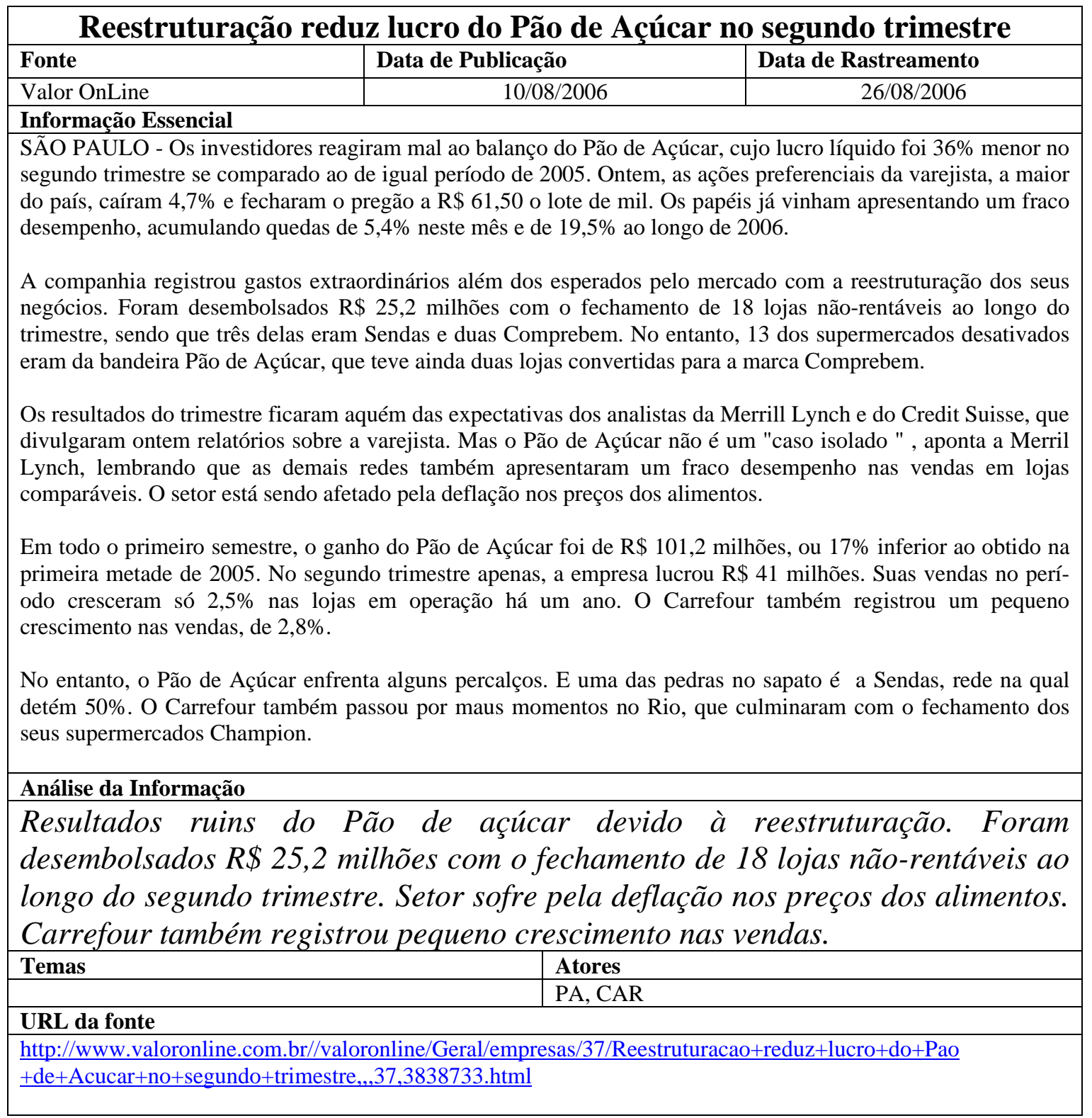


23

\section{Vendas de supermercados caíram 4,04\% em maio, diz Abras}

\begin{tabular}{|l|c|c|}
\hline Fonte & Data de Publicação & Data de Rastreamento \\
\hline ValorOnLine & $\mathbf{2 1 / 0 6 / 2 0 0 6}$ & $\mathbf{1 5 / 0 8 / 2 0 0 6}$ \\
\hline In &
\end{tabular}

\section{Informação Essencial}

As vendas do setor supermercadista apresentaram em maio queda de 4,04\% em valores reais (deflacionados pelo IPCA) em relação ao mesmo mês do ano passado, informou hoje a Associação Brasileira de Supermercados (Abras). Na comparação com abril, a queda real das vendas chegou a 8,51\%. No acumulado do ano, o declínio é de $2,83 \%$.

De acordo com a entidade, o feriado de Páscoa, considerado o segundo melhor momento de vendas para o setor, pode explicar a queda na comparação com abril. Além disso, o descompasso do calendário (cinco finais de semana em abril contra quatro em maio) também contribuiu, segundo a entidade, para a retração das vendas em maio.

No que diz respeito aos preços praticados pelos supermercados, o indicador criado pela associação, chamado AbrasMercado, reportou queda real de $0,23 \%$ em maio na comparação com o mês anterior. A cesta com 35 produtos de alto consumo pesquisada pela entidade, passou de $\mathrm{R} \$ 194,12 \mathrm{em}$ abril para $\mathrm{R} \$ 193,67$ no mês passado. Em relação a maio de 2005 , houve redução de $6,63 \%$ no valor da cesta.

\section{Comentários}

Vendas de maio em queda (4\%) em relação a mesmo período de 2005.

Temas Atores

URL da fonte

Mercado Supermercadista 


\section{4}

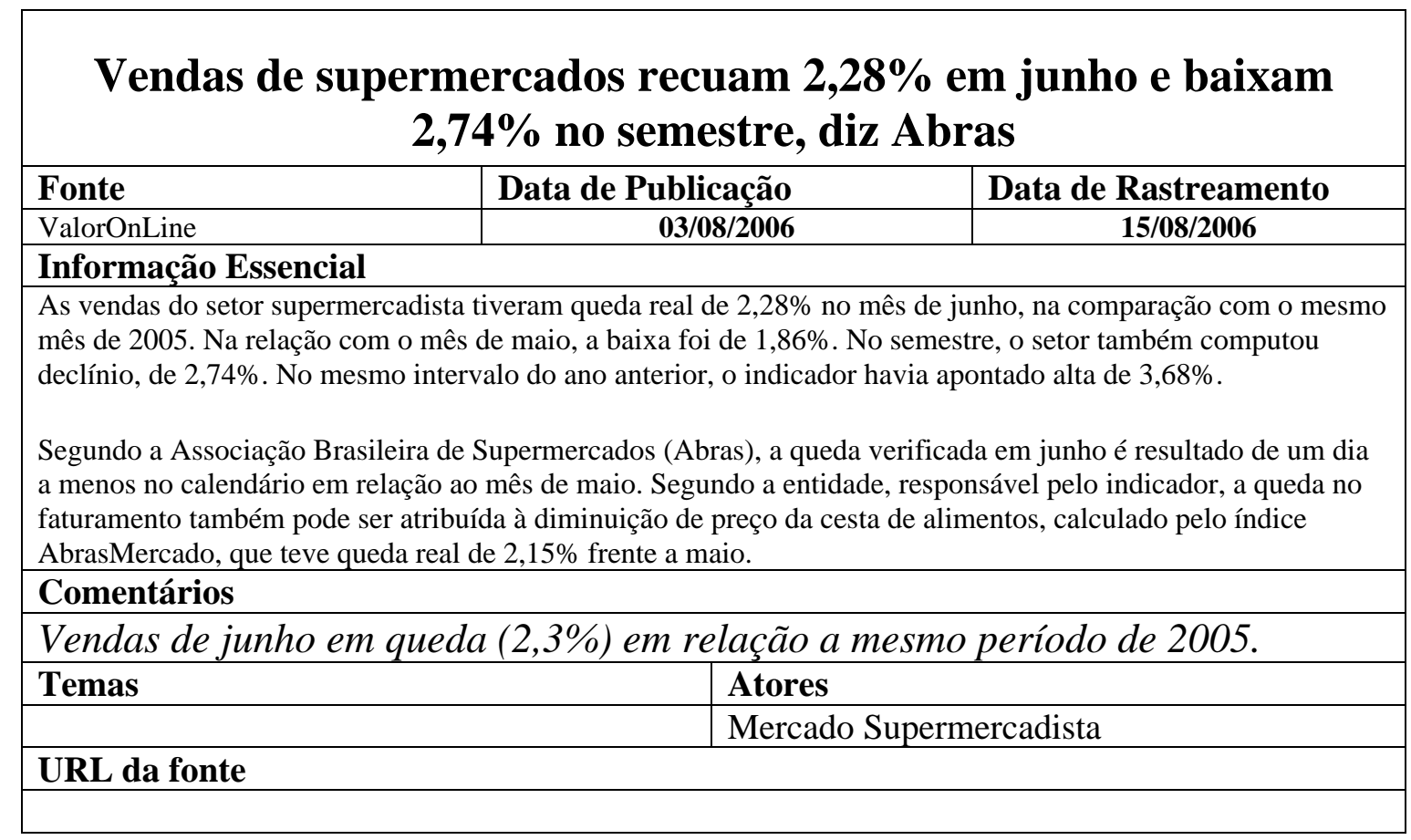




\section{Vendas do Carrefour crescem 9,2\% no Brasil no segundo trimestre}

\begin{tabular}{|l|l|l|}
\hline Fonte & Data de Publicação & Data de Rastreamento \\
\hline
\end{tabular}

\begin{tabular}{|l|r|r}
\hline ValorOnLine & 13/07/2006 & 26/08/2006 \\
\hline
\end{tabular}

Informação Essencial

As vendas do Carrefour no Brasil cresceram 9,2\% no segundo trimestre, em relação a igual período do ano passado, e somaram 1,1 bilhão de euros ( $\mathrm{R} \$ 2,4$ bilhões). O valor representa $65 \%$ da receita do grupo na América Latina, que aumentou $24 \%$, chegando a 1,7 bilhão de euros.

A empresa, em nota, informou que a expansão nas vendas dos hipermercados no Brasil, sem considerar lojas novas, foi de 1,8\%. "As vendas continuam a ser fortemente impactadas pela deflação dos alimentos, e por nossa decisão de reposicionar nossos preços no começo do ano ", declarou a empresa. A rede contabiliza também o desempenho de 33 lojas sob a bandeira Carrefour Bairro.

A redução de preços e a abertura de novas lojas na Ásia e na América Latina foram considerados fatores principais para o aumento de $9,1 \%$ nas vendas mundiais. As vendas globais somaram 21,4 bilhões de euros (US\$ 27,1 bilhões), pouco acima das previsões. Na América Latina, a receita arrecadada pelo Carrefour cresceu 24\%; na Ásia, 16\%. As vendas na Europa, com exceção da França, aumentaram 7,9\%. Na França, o aumento foi de $7,2 \%$.

O Carrefour disse que pretende incorporar 1,5 milhão de metros quadrados de espaço de vendas em 2006. No segundo trimestre deste ano, a varejista inaugurou 232 lojas em todo o mundo, entre as quais 10 na América Latina e 22 na Ásia, incluindo-se a China. São, no mundo, 12.185 lojas.

\section{Comentários}

Apesar da queda geral de vendas apontada no setor o Carrefour as vendas do Carrefour no Brasil cresceram 9,2\% no segundo trimestre, em relação a igual período do ano passado. No segundo trimestre inaugurou 10 lojas na AL e 22 na Ásia, incluindo-se a China.

\begin{tabular}{|c|c|}
\hline Temas & Atores \\
\hline & CAR \\
\hline
\end{tabular}




\section{Vendas do grupo Pão de Açúcar caem 3,5\% em maio no conceito de mesmas lojas}

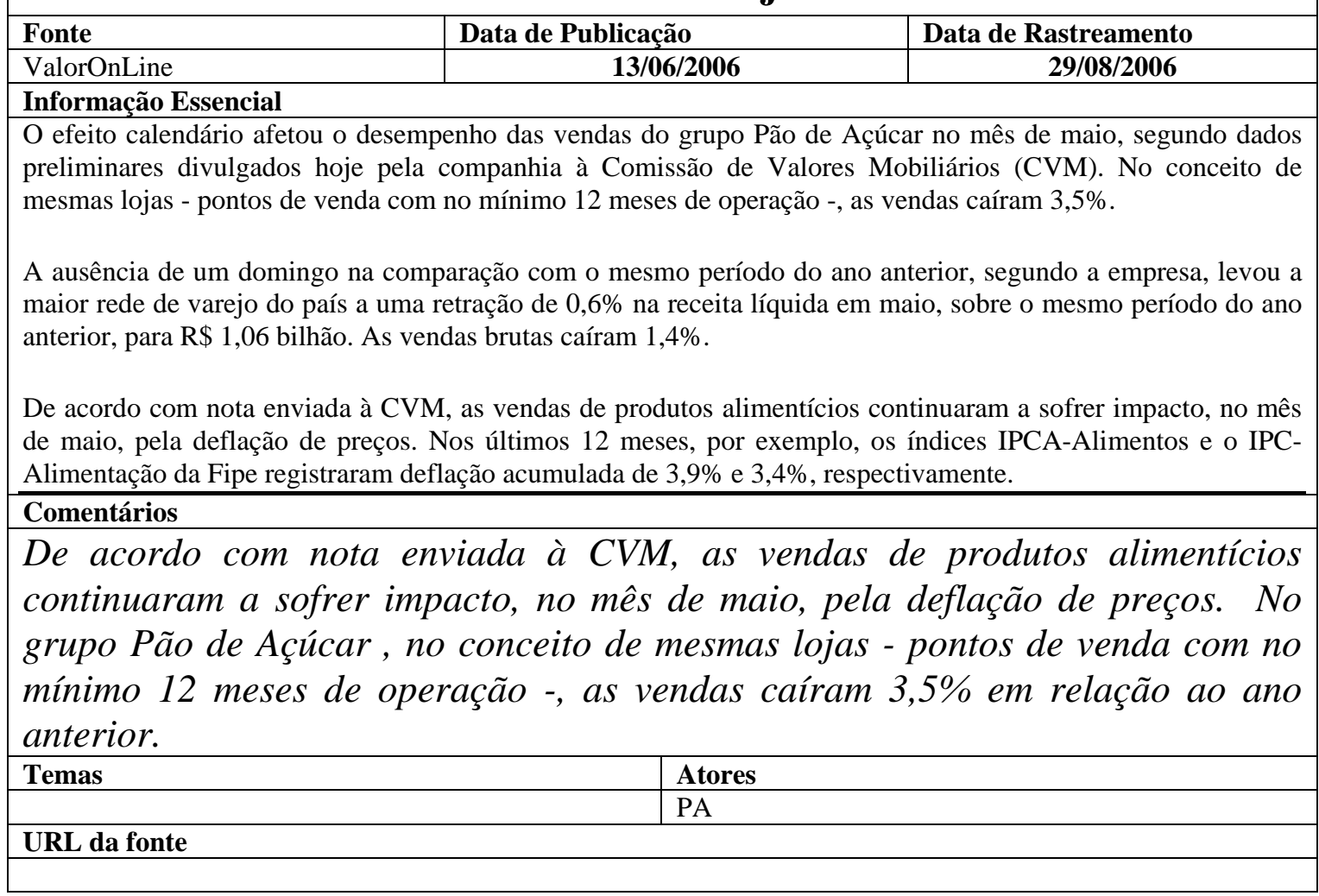




\section{Vendas dos supermercados brasileiros caem 3,37\% em julho ante 2005}

\begin{tabular}{|l|c|c|}
\hline Fonte & Data de Publicação & Data de Rastreamento \\
\hline ValorOnLine & $31 / 08 / 2006$ & $15 / 08 / 2006$ \\
\hline Informação Essencial & & \\
\hline A & &
\end{tabular}

As vendas do setor supermercadista tiveram queda real de 3,37\% no mês de julho, na comparação com o mesmo mês de 2005. Na relação com o mês de junho, no entanto, houve alta de 4,63\%. Já no acumulado do ano, o setor computou declínio de $2,83 \%$. No mesmo intervalo do ano anterior, o indicador havia apontado alta de $3,11 \%$.

Segundo a Associação Brasileira de Supermercados (Abras), o crescimento observado em julho, na comparação com o mês anterior, é atribuído ao calendário, pois junho deste ano contou com 30 dias e 4 finais de semana, enquanto julho teve 31 dias e 5 finais de semana. As promoções realizadas pelo setor também ajudaram a elevar as vendas, segundo a entidade.

\section{Comentários}

Vendas de julho em queda (3,4\%) em relação a mesmo período de 2005.

Temas Atores

URL da fonte

Mercado Supermercadista 
28

\begin{tabular}{|c|c|c|}
\hline \multicolumn{3}{|c|}{$\begin{array}{l}\text { Vendas nas lojas da Wal-Mart abertas há } 12 \text { meses nos EUA } \\
\text { sobem } 1,2 \% \text { em junho }\end{array}$} \\
\hline Fonte & Data de Publicação & Data de Rastreamento \\
\hline ValorOnLine & 06/07/2006 & $26 / 08 / 2006$ \\
\hline \multicolumn{3}{|c|}{ Informação Essencial } \\
\hline \multicolumn{3}{|c|}{$\begin{array}{l}\text { As vendas das lojas da Wal-Mart Stores Inc. abertas há pelo menos } 12 \text { meses nos Estados Unidos cresceram } \\
1,2 \% \text { em junho. O faturamento total da companhia aumentou } 10,4 \% \text { no mês passado, ficando em US } 33,12 \\
\text { bilhões, ante os US } \$ 29,99 \text { bilhões de mesmo período de } 2005 \text {. }\end{array}$} \\
\hline \multicolumn{3}{|l|}{ Comentários } \\
\hline \multicolumn{3}{|c|}{$\begin{array}{l}\text { O faturamento total da WM mudialmente aumentou 10,4\% em junho, ficando } \\
\text { em US\$33,12 bilhões, ante os US\$29,99 bilhões de mesmo periodo de } 2005 \text {. }\end{array}$} \\
\hline \multirow[t]{2}{*}{ Temas } & & Atores \\
\hline & WM & \\
\hline \multicolumn{3}{|l|}{ URL da fonte } \\
\hline
\end{tabular}




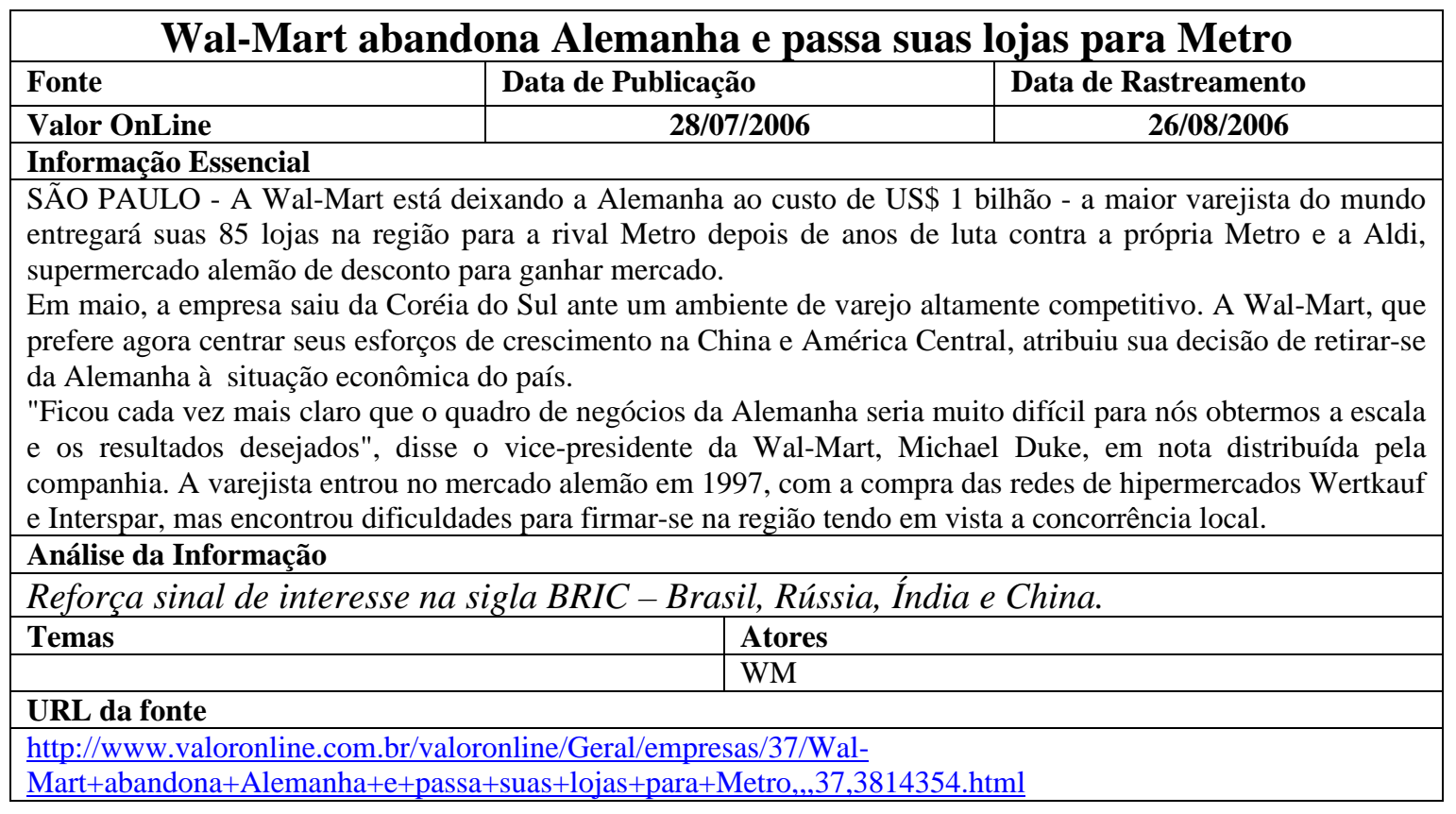


31

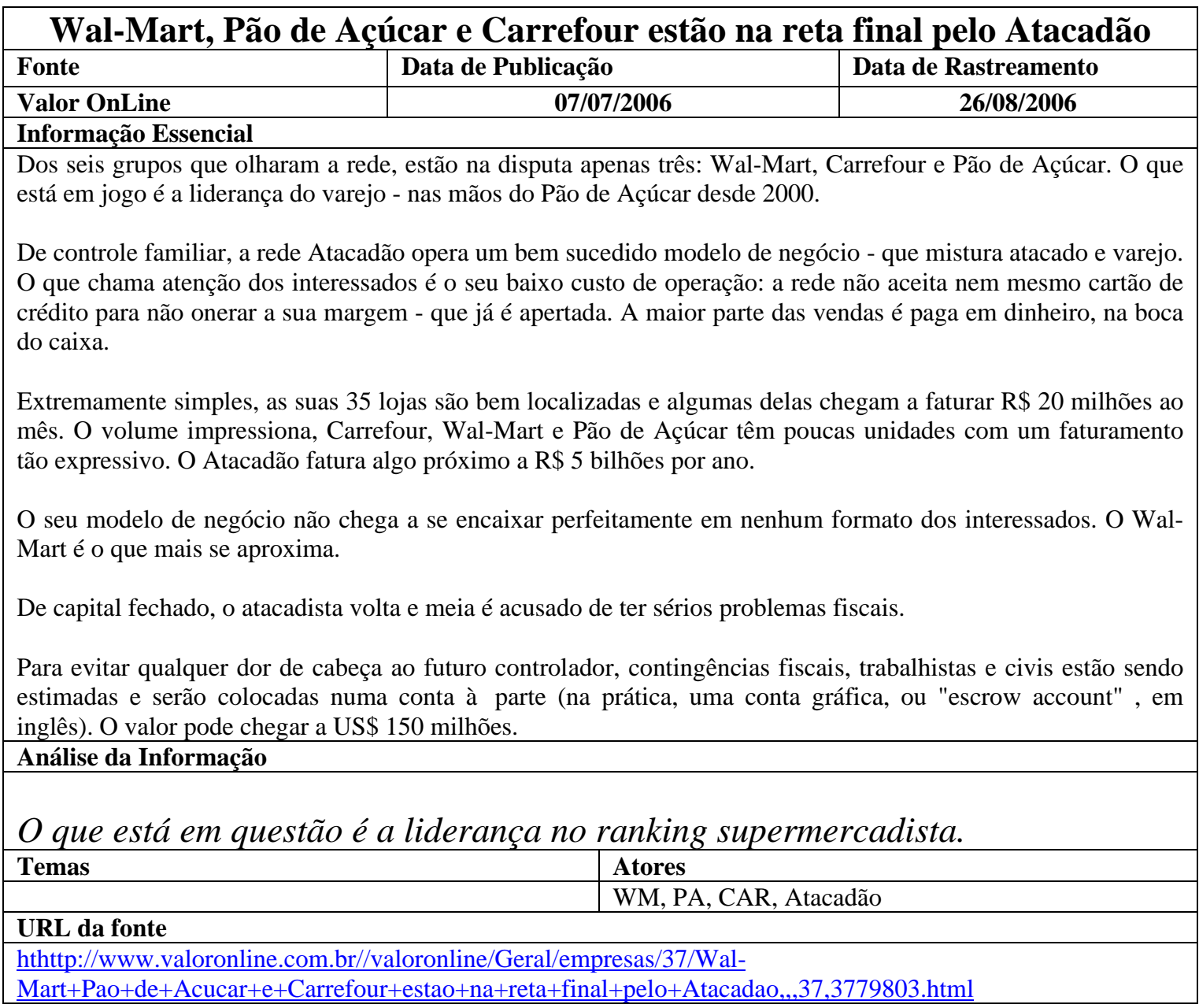


32

\begin{tabular}{|c|c|c|}
\hline \multicolumn{3}{|c|}{ Bancos agora almejam varejo regional } \\
\hline Fonte & \multirow{2}{*}{$\frac{\text { Data de Publicação }}{12 / 06 / 2006}$} & Data de Rastreamento \\
\hline Folha OnLine & & \\
\hline \multicolumn{3}{|c|}{ Informação Essencial } \\
\hline \multicolumn{3}{|c|}{ Grandes bancos continuam a sondar redes cobiçadas na caça de novas parcerias. } \\
\hline \multicolumn{3}{|c|}{$\begin{array}{l}\text { Na lista das mais desejadas, estão: Lojas Insinuante, da Bahia, a rede gaúcha de supermercados Zaffari e a } \\
\text { popular Marabraz, apurou a Folha. Na Renner, o interesse está em fechar parceria para vender seguros. }\end{array}$} \\
\hline \multicolumn{3}{|c|}{$\begin{array}{l}\text { A Folha calculou que, desde 2001, } 36 \text { lojas fecharam acordo com bancos na área de crédito, nos mais diferentes } \\
\text { modelos de parceria. Entre os bancos, já começaram as sondagens às redes de varejo de médio porte. }\end{array}$} \\
\hline \multicolumn{3}{|c|}{$\begin{array}{l}\text { O banco Bradesco já fechou contratos com redes com um potencial de venda total de } \mathrm{R} \$ 15 \text { bilhões. } \\
\text {...negociando mais convênios com lojas que tenham expectativa anual de vendas de mais } \mathrm{R} \$ 10 \text { bilhões." }\end{array}$} \\
\hline \multicolumn{3}{|c|}{$\begin{array}{l}\text { O foco é ampliar acordos que permitam ter acesso ao cliente na loja, montando uma estrutura enxuta para } \\
\text { comercializar serviços (empréstimos, seguro, abertura de contas). Os custos da implantação da operação são } \\
\text { divididos com as lojas. Nesse modelo mais avançado, há a criação de uma nova empresa (50\% da loja, } 50 \% \text { do } \\
\text { banco). }\end{array}$} \\
\hline \multicolumn{3}{|c|}{$\begin{array}{l}\text { Assim, o varejo ganha o acesso fácil ao capital que financia seu consumidor. Está cada vez mais difícil crescer } \\
\text { com dinheiro do próprio bolso --caro no país e, por vezes, escasso. }\end{array}$} \\
\hline \multicolumn{3}{|c|}{ O Pão de Açúcar tem um modelo desse tipo com o Itaú, e o Magazine Luiza, com o Unibanco. } \\
\hline \multicolumn{3}{|c|}{$\begin{array}{l}\text { Na quinta, o Bradesco e a rede de varejo sergipana G. Barbosa fizeram uma aliança nesses moldes... O negócio } \\
\text { foi fechado num momento em que o Unibanco, com o Wal-Mart, traz a São Paulo o cartão HiperCard, } \\
\text { administrado pela companhia nas lojas BomPreço, da rede americana no Nordeste. }\end{array}$} \\
\hline \multicolumn{3}{|c|}{$\begin{array}{l}\text { O Cetelem, banco francês que tem convênios com Carrefour e Lojas Maia, tem negociado com redes com } \\
\text { faturamento anual de } \mathrm{R} \$ 500 \text { milhões a } \mathrm{R} \$ 800 \text { milhões de vários segmentos. }\end{array}$} \\
\hline \multicolumn{3}{|l|}{ Comentários } \\
\hline \multicolumn{3}{|c|}{$\begin{array}{l}\text { A Folha calculou que, desde 2001, } 36 \text { lojas fecharam acordo com bancos na área de crédito, } \\
\text { nos mais diferentes modelos de parceria. Entre os bancos, já começaram as sondagens às } \\
\text { redes de varejo de médio porte. }\end{array}$} \\
\hline \multicolumn{3}{|c|}{$\begin{array}{l}\text { O foco é ampliar acordos que permitam ter acesso ao cliente na loja, montando uma } \\
\text { estrutura enxuta para comercializar serviços. Nesse modelo mais avançado, há a criação de } \\
\text { uma nova empresa (50\% da loja, } 50 \% \text { do banco). }\end{array}$} \\
\hline \multicolumn{3}{|c|}{ O Pão de Açúcar tem um modelo desse tipo com o Itaú, e o Magazine Luiza, com o Unibanco. } \\
\hline \multicolumn{3}{|c|}{$\begin{array}{l}\text { O Bradesco e a rede de varejo sergipana G. Barbosa fizeram uma aliança nesses moldes. } \\
\text { O Unibanco, com o Wal-Mart, traz a São Paulo o cartão HiperCard, administrado pela } \\
\text { companhia nas lojas BomPreço. O Cetelem, banco francês que tem convênios com Carrefour } \\
\text { e Lojas Maia. }\end{array}$} \\
\hline \multirow[t]{2}{*}{ Temas } & & Atores \\
\hline & & ercadista, Setor bancário \\
\hline
\end{tabular}


33

BNDES aprova financiamento de $\mathbf{R} \$ \mathbf{3 0}$ milhões para Magazine

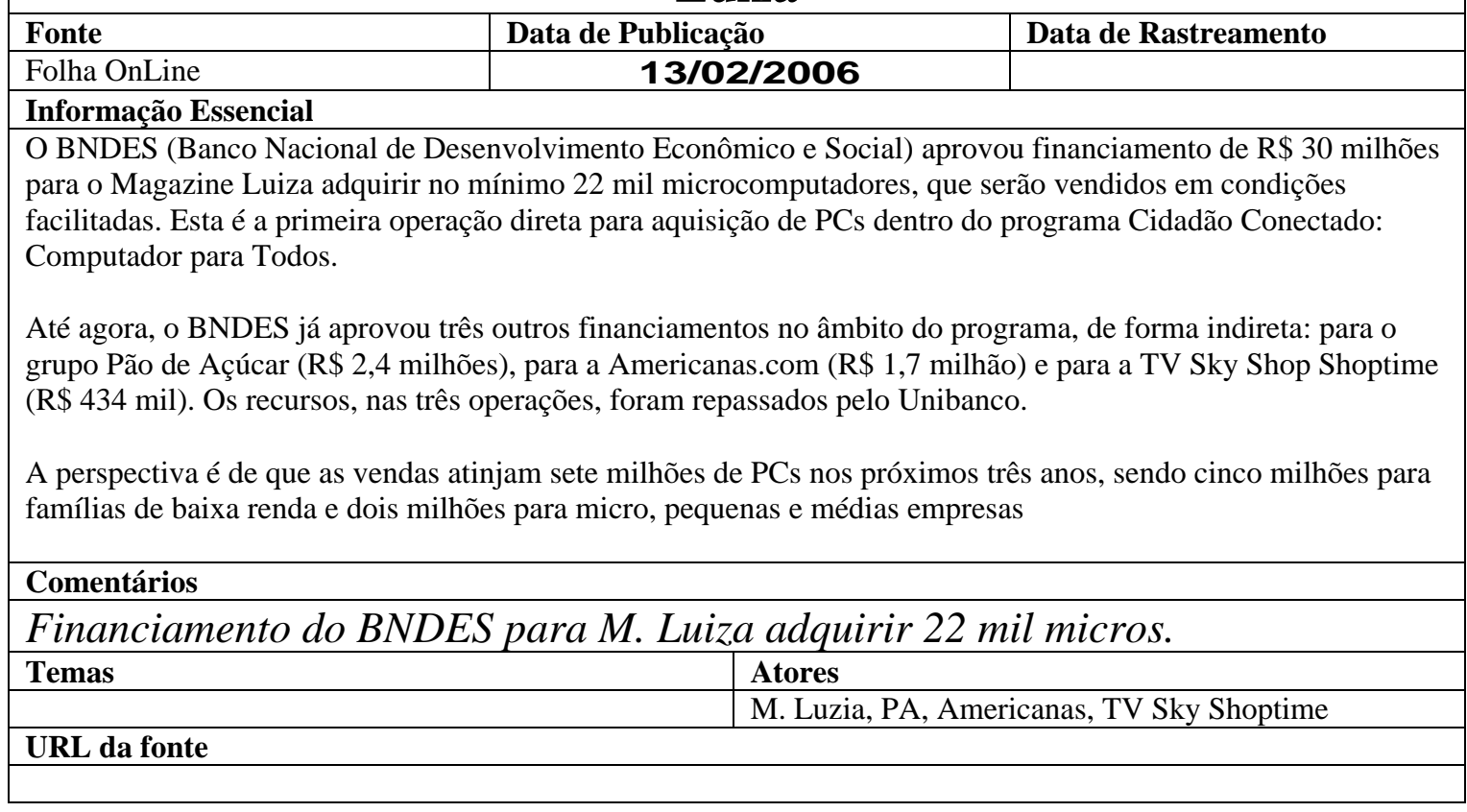


34

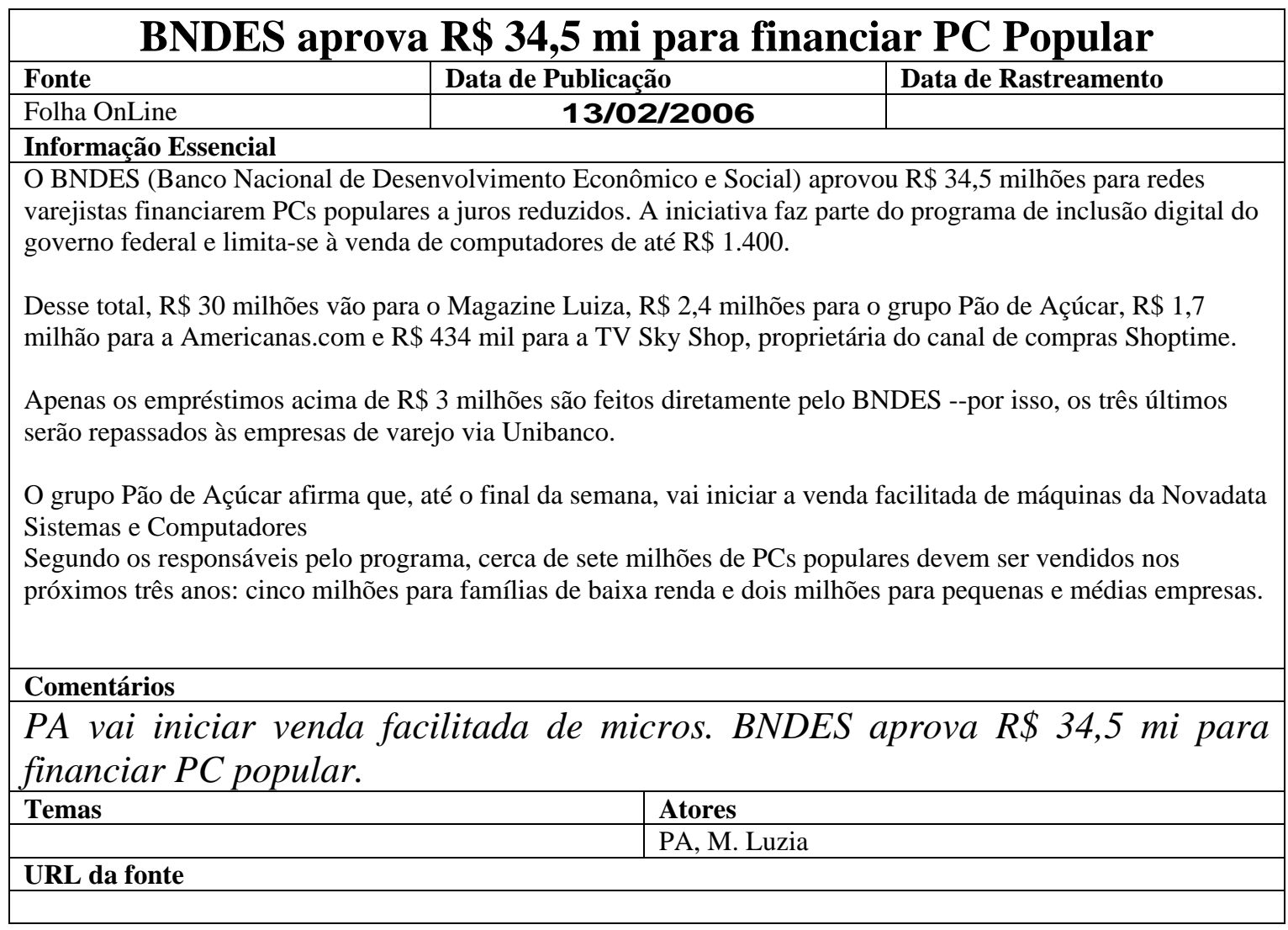


35

\begin{tabular}{|l|c|c|}
\hline Carrefour compra dez supermercados BIG e amplia concentração no setor \\
\hline Fonte & Data de Publicação & Data de Rastreamento \\
\hline Folha OnLine & $08 / 06 / 2005$ & $31 / 08 / 2006$ \\
\hline Informação Essencial & & \\
\hline
\end{tabular}

O Carrefour Brasil anunciou hoje a compra de dez supermercados da bandeira BIG, todos localizados no Estado de São Paulo. As lojas, que pertenciam antes ao grupo Sonae, foram compradas por R \$ 317 milhões.

Com essa transação, o Carrefour pretende melhorar sua participação no setor supermercadista brasileiro. Hoje, o grupo é o segundo do mercado, logo atrás do Pão de Açúcar. Em nota, o Carrefour informou que o negócio faz parte da estratégia mundial de "buscar uma posição de liderança nos mercados em que atua".

Além de tentar ganhar mercado por meio da aquisição de outras redes, o Carrefour também está investindo na construção de novas unidades. Duas novas lojas Carrefour serão inauguradas na próxima semana: uma em Fortaleza (CE) e outra em João Pessoa (PB).

Não é de hoje que o Sonae tenta se desfazer do BIG em São Paulo. O objetivo do grupo de origem portuguesa é para centrar sua atuação no sul do país, com as redes Nacional e Mercadorama.

A aquisição anunciada hoje deve ampliar ainda mais a concentração do setor supermercadista. No ano passado, o faturamento dos cinco maiores grupos representou $40 \%$ da receita total. Em 2003, a participação desses cinco primeiros correspondia a 37\% do faturamento total, segundo ranking divulgado pela Abras (Associação Brasileira de Supermercados).

Análise da Informação

Valor de transação da compra da Rede Big pelo Carrefour foi de $R \$ 317$ milhões.

Temas

URL da fonte

CA, Sonae, Big

inttp://www1.folha.uol.com.br/folha/dinheiro/ult91 u97083.shtmi 
36

\begin{tabular}{|c|c|c|}
\hline \multicolumn{3}{|c|}{ Carrefour cresce mais que grupo Pão de Açúcar } \\
\hline Fonte & Data de Publicação & Data de Rastreamento \\
\hline Folha OnLine & \multirow[t]{2}{*}{ 14/07/2006 } & 31/08/2006 \\
\hline \multicolumn{2}{|c|}{ Informação Essencial } & \\
\hline \multicolumn{3}{|c|}{$\begin{array}{l}\text { As duas maiores redes de supermercados do país, o grupo Pão de Açúcar e o Carrefour, faturaram pouco mais de } \\
\mathrm{R} \$ 14 \text { bilhões de janeiro a junho (valor bruto nominal), alta de } 8,8 \% \text { em relação a } 2005 \text {. No segundo trimestre, o } \\
\text { resultado do Carrefour foi melhor do que o do concorrente, o Pão de Açúcar. As redes continuam a ter } \\
\text { desempenhos ruins no critério de vendas reais (mesmas lojas) em relação a } 2005 \text {. }\end{array}$} \\
\hline \multicolumn{3}{|c|}{$\begin{array}{l}\text { De janeiro a junho, a rede administrada por Abilio Diniz e o parceiro Casino teve receita bruta de } R \$ 7,9 \text { bilhões, } \\
\text { contra } R \$ 7,7 \text { bilhões em igual intervalo de } 2005 \text {. O Carrefour somou } 2,2 \text { bilhões --o que equivale a } R \$ 6,1 \\
\text { bilhões, segundo a cotação da moeda européia em } 30 \text { de junho de } 2006 \text {, ou } R \$ 1 \text { bilhão a mais que em } 2005 \text {. }\end{array}$} \\
\hline \multicolumn{3}{|c|}{$\begin{array}{l}\text { Ao retirar dessa conta o impacto do câmbio para a rede francesa, a situação é a seguinte: de janeiro a junho, o } \\
\text { Carrefour cresceu } 8,7 \% \text { em vendas brutas --informa o balanço publicado no exterior. O Pão de Açúcar, pelo } \\
\text { mesmo critério, teve alta de 2,2\%. Nesse cálculo está o desempenho nominal de todas as lojas das duas redes. }\end{array}$} \\
\hline \multicolumn{3}{|c|}{$\begin{array}{l}\text { Pelos dados publicados, a venda bruta do Pão de Açúcar subiu } 2,5 \% \text { de abril a junho (para o conceito de mesmas } \\
\text { lojas que tinha em 2005, o que expurga o efeito inauguração e aquisições). No mesmo período, o Carrefour } \\
\text { cresceu } 2,8 \% \text {. }\end{array}$} \\
\hline \multicolumn{3}{|c|}{$\begin{array}{l}\text { Boa parte dessa taxa de expansão da rede francesa veio da venda em supermercados --que registrou desempenho } \\
\text { fraco em 2005--, e não dos hipermercados da cadeia. }\end{array}$} \\
\hline \multicolumn{3}{|c|}{$\begin{array}{l}\text { O Pão de Açúcar publicou dados de vendas líqüidas ontem, mas o Carrefour, que é de capital fechado no Brasil, } \\
\text { não informa esse número. A rede brasileira teve alta de } 3,3 \% \text { em sua venda líquida (todas as lojas) no primeiro } \\
\text { semestre. }\end{array}$} \\
\hline \multicolumn{3}{|c|}{$\begin{array}{l}\text { A dor de cabeça das varejistas de supermercados continua sendo a venda real em mesmas lojas --um dado que } \\
\text { não publicam. Esse número é relevante e mostra que não há recuperação no desempenho para as companhias, } \\
\text { apurou a Folha. }\end{array}$} \\
\hline \multicolumn{3}{|c|}{ Análise da Informação } \\
\hline \multicolumn{3}{|c|}{ Resultados do Pão de Açúcar desapontam.Carrefour cresce mais no primeiro semestre. } \\
\hline \multirow[t]{2}{*}{ Temas } & Atores & \\
\hline & $\mathrm{PA}$, & \\
\hline \multicolumn{3}{|l|}{ URL da fonte } \\
\hline \multicolumn{3}{|c|}{ http://www1.folha.uol.com.br/folha/dinheiro/noticias-6.shtml } \\
\hline
\end{tabular}


37

\begin{tabular}{|c|c|c|}
\hline \multicolumn{3}{|c|}{ Carrefour vai contratar 165 profissionais em São Paulo } \\
\hline Fonte & \multirow{2}{*}{$\frac{\text { Data de Publicação }}{10 / 03 / 2006}$} & Data de Rastreamento \\
\hline Folha OnLine & & \\
\hline \multicolumn{3}{|c|}{ Informação Essencial } \\
\hline \multicolumn{3}{|c|}{$\begin{array}{l}\text { O Carrefour contrata a partir desta segunda-feira (13), } 165 \text { profissionais para trabalhar em diversas lojas da rede na cidade de } \\
\text { São Paulo e cidades da região metropolitana. }\end{array}$} \\
\hline \multicolumn{3}{|c|}{$\begin{array}{l}\text { As vagas estão distribuídas nas funções de auxiliar de perecíveis, açougueiro, confeiteiro, empacotador, fiscal de loja, } \\
\text { peixeiro, padeiro, operador de caixa, repositor, supervisor de vendas e vendedor. O processo seletivo só será encerrado após o } \\
\text { preenchimento de todas as funções. }\end{array}$} \\
\hline \multicolumn{3}{|c|}{ Comentários } \\
\hline \multicolumn{3}{|c|}{ Carrefour vai contratar 165 profissionais operacionais em São Paulo. } \\
\hline \multirow[t]{2}{*}{ Temas } & \multirow{2}{*}{\multicolumn{2}{|c|}{$\begin{array}{l}\text { Atores } \\
\text { CAR }\end{array}$}} \\
\hline & & \\
\hline \multicolumn{3}{|c|}{ URL da fonte } \\
\hline
\end{tabular}




\section{8}

\section{Dólar cai e Bovespa diminui ritmo de alta; risco cai para menor valor na história}

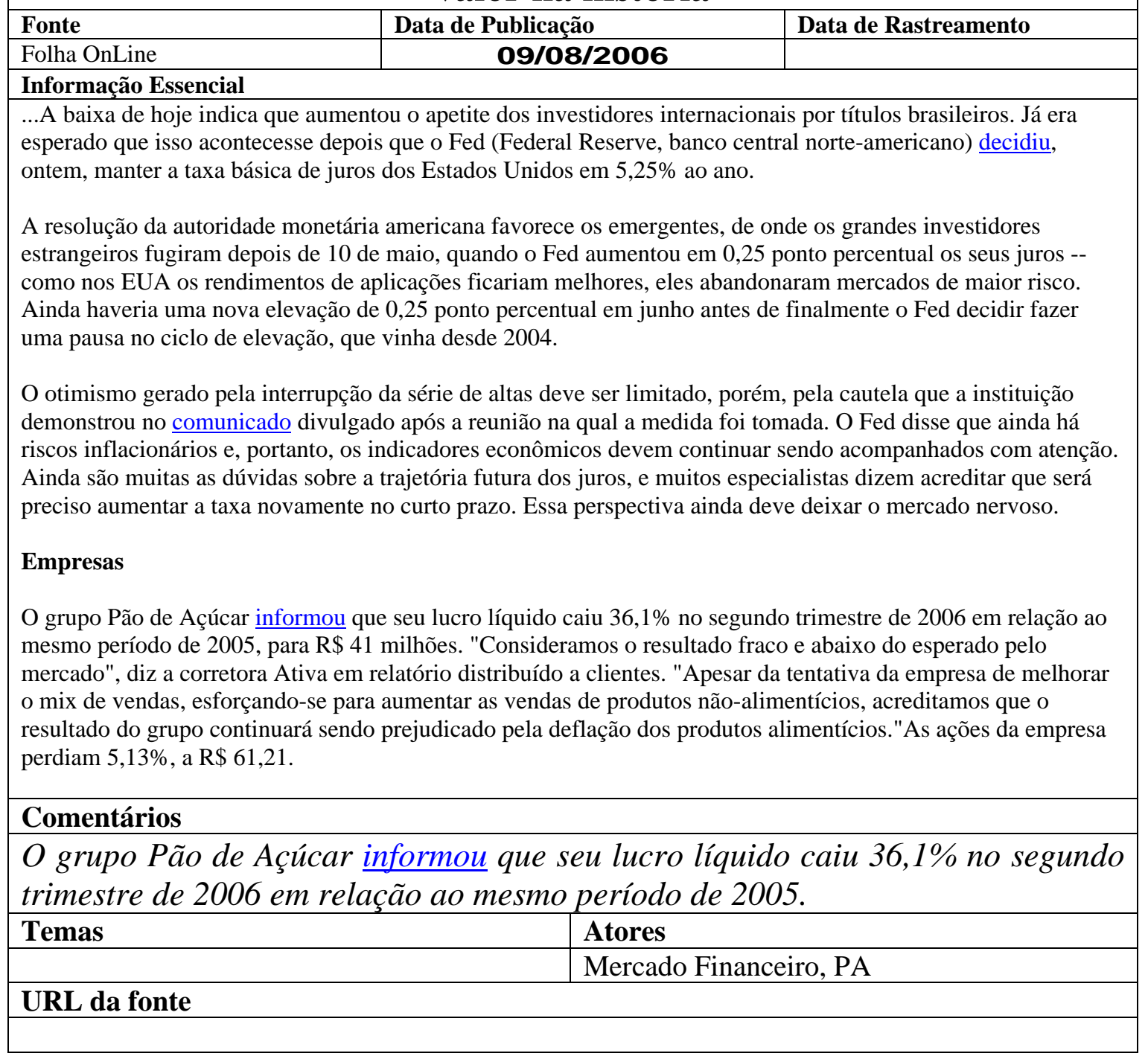




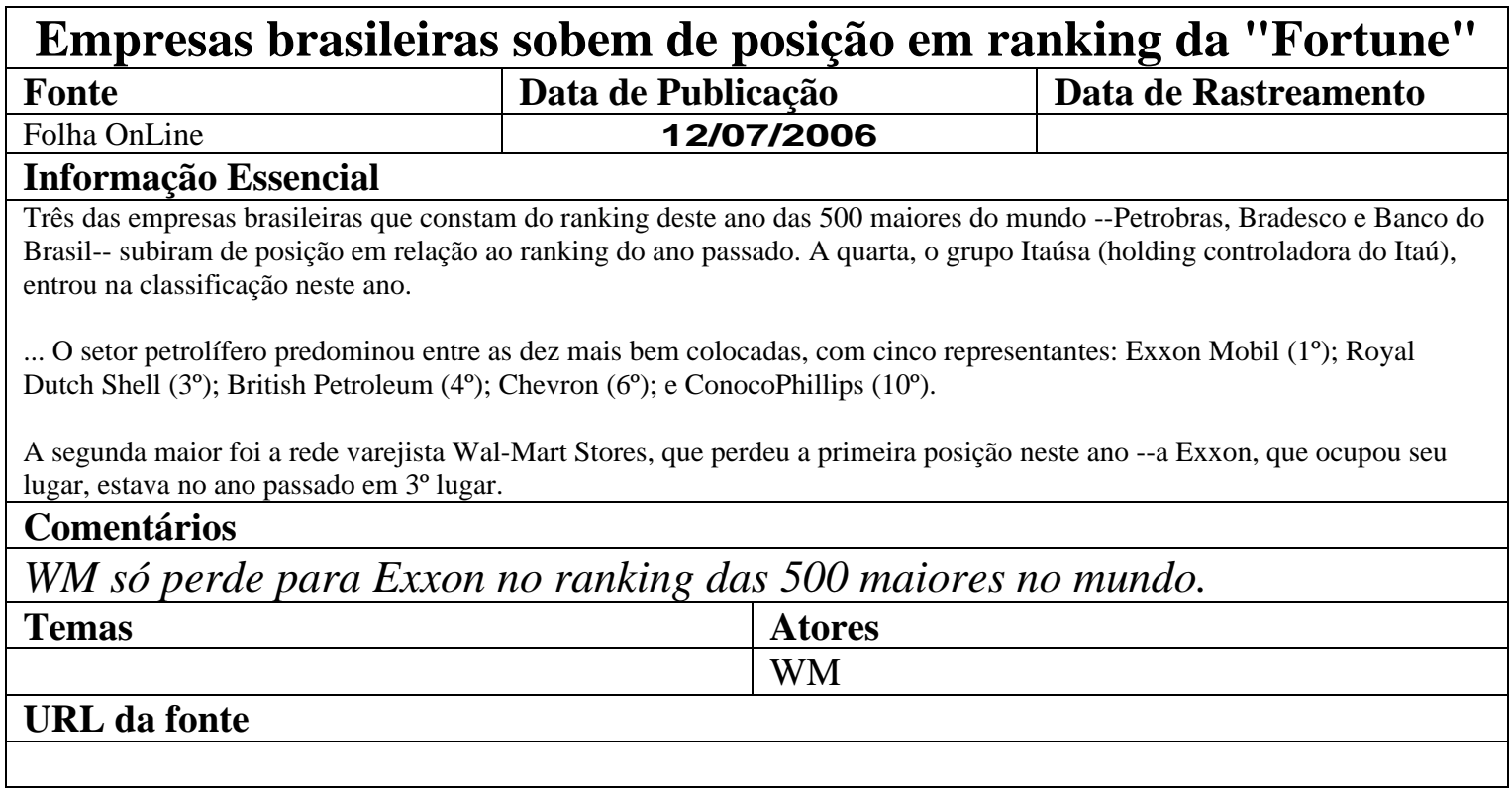


40

\begin{tabular}{|c|c|c|}
\hline \multicolumn{3}{|c|}{ Gigante Wal-Mart compra lojas do Sonae no Brasil por $\mathbf{R} \$ 1,7$ bi } \\
\hline Fonte & Data de Publicação & Data de Rastreamento \\
\hline Folha OnLine & \multirow{2}{*}{$14 / 12 / 2005$} & 31/08/2006 \\
\hline \multicolumn{2}{|c|}{ Informação Essencial } & \\
\hline \multicolumn{3}{|c|}{$\begin{array}{l}\text { O grupo português Sonae anunciou hoje a venda dos supermercados de sua subsidiária brasileira ao Wal-Mart, } \\
\text { maior empresa de varejo do mundo, por } 635 \text { milhões de euros (R\$ } 1,729 \text { bilhão). }\end{array}$} \\
\hline \multicolumn{3}{|c|}{$\begin{array}{l}\text { Em comunicado enviado à Comissão do Mercado de Valores Mobiliários (o órgão regulador do mercado } \\
\text { português), o Sonae, que no Brasil possui } 140 \text { lojas localizadas na região Sul com as bandeiras Nacional, BIG, } \\
\text { Mercadorama e Maxxi, informa que a decisão foi influenciada "pela dificuldade da operação em apresentar } \\
\text { níveis de rentabilidade superiores ao elevado custo do capital", sobretudo devido "às elevadas taxas de juro reais } \\
\text { verificadas ao longo dos últimos anos, que colocaram o custo do capital em patamares extremamente elevados". }\end{array}$} \\
\hline \multicolumn{3}{|c|}{$\begin{array}{l}\text { Segundo o "Jornal de Negócios", de Portugal, a transação acontece um dia após o diretor-geral do Carrefour, } \\
\text { Jean-Marc Pueyo, afirmar estar disponível para negociar a aquisição de lojas da portuguesa Sonae no Sul do } \\
\text { Brasil caso não houvesse entendimento com a Wal-Mart. }\end{array}$} \\
\hline \multicolumn{3}{|c|}{ Análise da Informação } \\
\hline \multicolumn{3}{|c|}{ Custo de compra da Sonae pela WM foi de $R \$ 1,7$ bi. } \\
\hline \multirow[t]{2}{*}{ Temas } & Atores & \\
\hline & WM & \\
\hline \multicolumn{3}{|l|}{ URL da fonte } \\
\hline \multicolumn{3}{|c|}{ http://www1.folha.uol.com.br/folha/dinheiro/ult 91 1u103362.shtm } \\
\hline
\end{tabular}


41

\begin{tabular}{|c|c|c|}
\hline \multicolumn{3}{|c|}{ Lucro do Pão de Açúcar cai 30\% em 2005 e atinge R\$ 257 milhões } \\
\hline Fonte & \multirow{2}{*}{\begin{tabular}{|r|} 
Data de Publicaçãa \\
$09 / 03 / 2006$ \\
\end{tabular}} & Data de Rastreamento \\
\hline Folha OnLine & & 31/08/2006 \\
\hline \multicolumn{3}{|c|}{ Informação Essencial } \\
\hline \multicolumn{3}{|c|}{$\begin{array}{l}\text { O grupo Pão de Açúçar --que também inclui lojas do CompreBem, Sendas, Extra e Extra-Eletro-- obteve lucro } \\
\text { líquido 30,5\% inferior em } 2005 \text { na comparação com 2004. No ano passado, o grupo ganhou R\$257 milhões, } \\
\text { contra R } \$ 369,8 \text { milhões do ano anterior. }\end{array}$} \\
\hline \multicolumn{3}{|c|}{$\begin{array}{l}\text { Após um forte primeiro trimestre, período em que o grupo registrou crescimento de } 15,5 \% \text {, as vendas } \\
\text { desaceleraram nos três trimestres seguintes. }\end{array}$} \\
\hline \multirow{2}{*}{\multicolumn{3}{|c|}{$\begin{array}{l}\text { Em contrapartida, no conceito mesmas lojas, o crescimento nominal acumulado no ano foi de } 2,6 \% \text {, } \\
\text { impulsionado pela boa performance registrada pelos produtos não-alimentícios que cresceram } 12,5 \% \text { no período. } \\
\text { Já as vendas brutas do grupo atingiram } R \$ 16,1 \text { bilhões em } 2005 \text {, com crescimento de } 5,4 \% \text { em relação a } 2004 \text {, } \\
\text { que obteve } R \$ 15,3 \text { bilhões. }\end{array}$}} \\
\hline & & \\
\hline \multicolumn{3}{|c|}{ Análise da Informação } \\
\hline \multicolumn{3}{|c|}{$\begin{array}{l}\text { Resultados do Pão de Açúcar desapontam. Lucro do Pão de Açúcar cai } 30 \% \text { em } \\
2005 \text { e atinge R\$ } 257 \text { milhões }\end{array}$} \\
\hline \multirow[t]{2}{*}{ Temas } & & Atores \\
\hline & PA & \\
\hline \multicolumn{3}{|l|}{ URL da fonte } \\
\hline \multicolumn{3}{|c|}{ 'http://www1. folha.uol.com.br/folha/dinheiro/ult91u105850.shtm/ } \\
\hline
\end{tabular}


42

\begin{tabular}{|c|c|c|}
\hline \multicolumn{3}{|c|}{$\begin{array}{c}\text { Lucro do Pão de Açúcar cai } 36 \% \text { no segundo trimestre e atinge R\$ } 41 \\
\text { milhões }\end{array}$} \\
\hline Fonte & Data de Publicação & Data de Rastreamento \\
\hline Folha OnLine & 08/08/2006 & $31 / 08 / 2006$ \\
\hline \multicolumn{3}{|c|}{ Informação Essencial } \\
\hline \multicolumn{3}{|c|}{$\begin{array}{l}\text { O grupo Pão de Açúcar --que também inclui lojas do CompreBem, Sendas, Extra e Extra-Eletro-- obteve lucro } \\
\text { líquido 36,1\% inferior no segundo trimestre de } 2006 \text { na comparação com } 2005 \text {. No período, o grupo ganhou R } \$ \\
41 \text { milhões, contra } \$ \$ 64,2 \text { milhões do segundo trimestre do ano passado. }\end{array}$} \\
\hline \multicolumn{3}{|c|}{$\begin{array}{l}\text { Segundo a rede, a redução ocorreu, principalmente, em função de resultados não-operacionais originados do } \\
\text { fechamento de lojas e de despesas não-recorrentes, relativas aos gastos com reestruturação. }\end{array}$} \\
\hline \multicolumn{3}{|c|}{$\begin{array}{l}\text { A rede de varejo também registrou queda no movimento do primeiro semestre, quando o lucro líquido teve } \\
\text { redução de } 17 \% \text {, na comparação com } 2005 \text {. Os valores chegaram a } R \$ 101,1 \text { milhões neste ano, contra } R \$ 121,9 \\
\text { milhões no ano passado. }\end{array}$} \\
\hline \multicolumn{3}{|c|}{$\begin{array}{l}\text { O grupo informou que, entre } 2005 \text { e 2006, fechou } 21 \text { lojas, sendo } 18 \text { neste ano, e converteu } 14 \text { para a bandeira } \\
\text { CompreBem. Em 2005, o lucro da rede registrou queda de } 30 \% \text { e atingiu R \$ } 257 \text { milhões. }\end{array}$} \\
\hline \multicolumn{3}{|c|}{ Em contrapartida, no conceito mesmas lojas, o crescimento das vendas foi de $2,5 \%$. } \\
\hline \multicolumn{3}{|c|}{$\begin{array}{l}\text { As vendas brutas do grupo cresceram } 4,9 \% \text { no segundo trimestre do ano na comparação com o mesmo período } \\
\text { de } 2005 \text {, para } R \$ 3,978 \text { bilhões, segundo dados informados pela empresa. As vendas líquidas chegaram a R\$ } \\
3,333 \text { bilhões no período, com alta de 5,6\%. }\end{array}$} \\
\hline \multicolumn{3}{|c|}{$\begin{array}{l}\text { O número de funcionários, que em } 31 \text { de dezembro de } 2005 \text { era de } 62,8 \text { mil, fechou o semestre reduzido para } \\
60,6 \text { mil. }\end{array}$} \\
\hline \multicolumn{3}{|c|}{$\begin{array}{l}\text { Para o segundo semestre a rede planeja a inauguração de lojas e, para isso, destinou investimento de } R \$ 142 \\
\text { milhões no segundo trimestre. No mesmo período do ano passado, o investimento foi de } R \$ 195,2 \text { milhões. No } \\
\text { primeiro semestre, os investimentos atingiram } R \$ 283 \text { milhões, contra } R \$ 334,1 \text { milhões em } 2005 \text {. }\end{array}$} \\
\hline \multicolumn{3}{|c|}{ Análise da Informação } \\
\hline \multicolumn{3}{|c|}{$\begin{array}{l}\text { Resultados do Pão de Açúcar desapontam. O grupo informou que, entre } 2005 \text { e } \\
2006, \text { fechou } 21 \text { lojas, sendo } 18 \text { neste ano, e converteu } 14 \text { para a bandeira } \\
\text { CompreBem. Em 2005, o lucro da rede registrou queda de } 30 \% \text { e atingiu } R \$ \\
257 \text { milhões. }\end{array}$} \\
\hline \multirow[t]{2}{*}{ Temas } & Atores & \\
\hline & PA & \\
\hline
\end{tabular}


43

\begin{tabular}{|c|c|c|}
\hline \multicolumn{3}{|c|}{ Lucro do Wal-Mart cai $26 \%$ no segundo trimestre } \\
\hline Fonte & Data de Publicação & Data de Rastreamento \\
\hline Folha OnLine & \multirow{2}{*}{ 15/08/2006 } & 31/08/2006 \\
\hline \multicolumn{2}{|c|}{ Informação Essencial } & \\
\hline \multicolumn{3}{|c|}{$\begin{array}{l}\text { O lucro da rede varejista americana Wal-Mart Stores (maior do mundo) teve uma queda de } 26 \% \text { no segundo } \\
\text { trimestre deste ano, na comparação anual, devido ao pagamento de encargos ligados à venda de suas operações } \\
\text { na Alemanha. }\end{array}$} \\
\hline \multicolumn{3}{|c|}{$\begin{array}{l}\text { A empresa lucrou no trimestre encerrado em } 31 \text { de julho US } \$ 2,08 \text { bilhões, contra US\$ } 2,81 \text { bilhões há um ano. } \\
\text { O resultado do trimestre passado incluiu o pagamento de US } \$ 863 \text { milhões em encargos relativos à venda de } \\
\text { suas lojas na Alemanha à rede varejista rival alemã Metro. }\end{array}$} \\
\hline \multicolumn{3}{|c|}{$\begin{array}{l}\text { Excluindo dos resultados as operações com as lojas na Alemanha e na Coréia do Sul, que estão em processo de } \\
\text { venda, o lucro com operações contínuas da empresa cresceu } 5 \% \text {, indo para US\$ 2,98 bilhões, contra US\$2,85 } \\
\text { bilhões registrados há um ano. }\end{array}$} \\
\hline \multicolumn{3}{|c|}{$\begin{array}{l}\text { A receita da empresa totalizou US } \$ 85,43 \text { bilhões, um aumento de } 11,4 \% \text { na comparação com os US\$ 76,69 } \\
\text { bilhões registrados há um ano. }\end{array}$} \\
\hline \multicolumn{3}{|c|}{$\begin{array}{l}\text { As vendas totais nas mesmas lojas (abertas há pelo menos um ano) no trimestre cresceram } 1,7 \% \text {--incluindo } \\
1,5 \% \text { de aumento nas vendas nas lojas Wal-Mart e 2,6\% de alta para as lojas Sam's Club. }\end{array}$} \\
\hline \multicolumn{3}{|c|}{ Análise da Informação } \\
\hline \multicolumn{3}{|c|}{ Problemas com resultados no setor. } \\
\hline \multirow[t]{2}{*}{ Temas } & Atores & \\
\hline & WM & \\
\hline
\end{tabular}


44

\begin{tabular}{|c|c|c|}
\hline \multicolumn{3}{|c|}{ Mesmo em baixa, juro de loja é maior no Brasil } \\
\hline Fonte & \multirow{2}{*}{$\begin{array}{l}\text { Data de Publicação } \\
20 / 02 / 2006\end{array}$} & Data de Rastreamento \\
\hline Folha OnLine & & \\
\hline \multicolumn{3}{|c|}{ Informação Essencial } \\
\hline \multicolumn{3}{|c|}{$\begin{array}{l}\text {... captar recursos no país para fazer financiamentos aos consumidores é uma operação cara por conta da pesada } \\
\text { taxa Selic ... Como essa taxa serve como uma espécie de balizador do mercado nessas operações, se ela não cai } \\
\text { de maneira que o mercado absorva essa queda, o dinheiro continua caro. A Selic cai há cinco meses seguidos, } \\
\text { mas o repasse ao mercado consumidor começou a aparecer neste ano. }\end{array}$} \\
\hline \multicolumn{3}{|c|}{$\begin{array}{l}\text { Além disso, a política de manutenção do chamado "spread" das financeiras das lojas --a diferença entre o custo } \\
\text { de captação da empresa e a taxa efetiva cobrada dos clientes-- também ajuda a evitar que as taxas de juros ao } \\
\text { consumidor fiquem mais competitivas. }\end{array}$} \\
\hline \multicolumn{3}{|c|}{$\begin{array}{l}\text { Nessa conta, o brasileiro paga mais pelo mesmo produto vendido em uma loja no exterior. ...o Wal-Mart, cobra } \\
\text { taxa máxima de } 17,99 \% \text { ao ano para a venda de bens duráveis nos EUA no boleto, o que dá } 1,38 \% \text { ao mês. Mas } \\
\text { essa compra no carnê é raríssima. O americano paga boa parte das compras sem juros no cartão. }\end{array}$} \\
\hline \multicolumn{3}{|c|}{$\begin{array}{l}\text { No Brasil, o juro mais baixo do Wal-Mart atingiu } 1,46 \%, \ldots . \text { Nesse caso, há um fator de peso: as redes que } \\
\text { cobrarem até } 2 \% \text { de juros para a venda de computadores, podem se financiar no BNDES com dinheiro barato. É } \\
\text { uma iniciativa do governo iniciada em } 2005 \text {. Fora desse segmento, a taxa média atinge } 2,5 \% \text { ao mês. }\end{array}$} \\
\hline \multicolumn{3}{|c|}{$\begin{array}{l}\text { No grupo Pão de Açúcar, que tem como sócio o francês Casino, as diferenças são grandes. A financeira Taí, do } \\
\text { banco Itaú, cobra taxas mensais que partem de } 1,99 \% \text { ao mês. Para produtos em geral, em } 18 \text { parcelas, ela atinge } \\
2,99 \% \text {--em linha com o praticado por Casas Bahia e Ponto Frio. Com a diferença de que nessas duas lojas a taxa } \\
\text { foi promocional. }\end{array}$} \\
\hline \multicolumn{3}{|c|}{$\begin{array}{l}\text { No Casino, parceiro da rede brasileira, os hipermercados Géant cobram uma taxa menor, que varia de } 14,90 \% \text { ao } \\
\text { ano a } 18,90 \% \text { ao ano --ou } 1,16 \% \text { a } 1,45 \% \text { ao mês-- para a compra de bens duráveis, segundo a empresa informa } \\
\text { em seu site. Mas essa taxa quem paga é uma minoria. Com o cartão da loja, pode-se pagar um valor mínimo e } \\
\text { financiar o resto em juros ainda mais baixos. Na rede inglesa de hipermercados Tesco, por exemplo, as taxas } \\
\text { anuais cobradas são a partir de } 10 \% \text { ao ano. }\end{array}$} \\
\hline \multicolumn{3}{|l|}{ Comentários } \\
\hline \multirow{2}{*}{\multicolumn{3}{|c|}{$\begin{array}{l}\text { O brasileiro paga mais pelo mesmo produto vendido em uma loja no exterior } \\
\text { devido às taxas de juros maiores, apesar de baixas para o Brasil. }\end{array}$}} \\
\hline & & \\
\hline Temas & & \begin{tabular}{|l|} 
Atores \\
WM, PA, Casino \\
\end{tabular} \\
\hline \multicolumn{3}{|l|}{ URL da fonte } \\
\hline
\end{tabular}


45

Pão de Açúcar compra Coopercitrus e amplia presença no interior de SP

\begin{tabular}{|l|l|c|}
\hline Fonte & Data de Publicação & Data de Rastreamento \\
\hline
\end{tabular}

\begin{tabular}{|l|r|r}
\hline Folha OnLine & 04/05/2005 & $31 / 08 / 2006$
\end{tabular}

Informação Essencial

O grupo Pão de Açúcar anunciou hoje a aquisição da rede de supermercados Coopercitrus. Com esse negócio, o grupo ampliará sua presença no interior de São Paulo.

A Coopercitrus possui sete unidades localizadas nas cidades de Barretos, Bebedouro, Guaíra, Orlândia, Olímpia e Viradouro.

Em Olímpia, são duas lojas. Em Guaíra, Barretos e Orlândia, a rede também possui postos de gasolina.

Com esse negócio, a concentração no setor varejista deve aumentar ainda mais. No ano passado, o grupo Pão de Açúcar faturou R \$ 15,43 bilhões. O resultado considera o desempenho das bandeiras Pão de Açúcar ,

CompreBem Barateiro, Extra e Sendas.

Com esse desempenho, o Pão de Açúcar foi o primeiro grupo supermercadista do país de 2004, segundo ranking a Abras (Associação Brasileira de Supermercados). O segundo lugar foi ocupado mais uma vez pelo carrefour que faturou R\$12,12 bilhões no ano passado. Até 2000, o carrefour era o líder do ranking da Abras e o segundo lugar era do Pão de Açúcar .

Com esse resultado, os dois maiores grupos supermercadistas do país passaram a concentrar 28\%. Em 2003, as duas maiores respondiam por $27 \%$ do faturamento de todo o setor. O valor da transação não foi divulgado.

Análise da Informação

Ampliação no interior de São Paulo pelo PA.

Temas $\quad$ Atores

URL da fonte

PA, Coopercitrus

inttp://www1.folha.uol.com.br/folha/dinheiro/ult91 
46

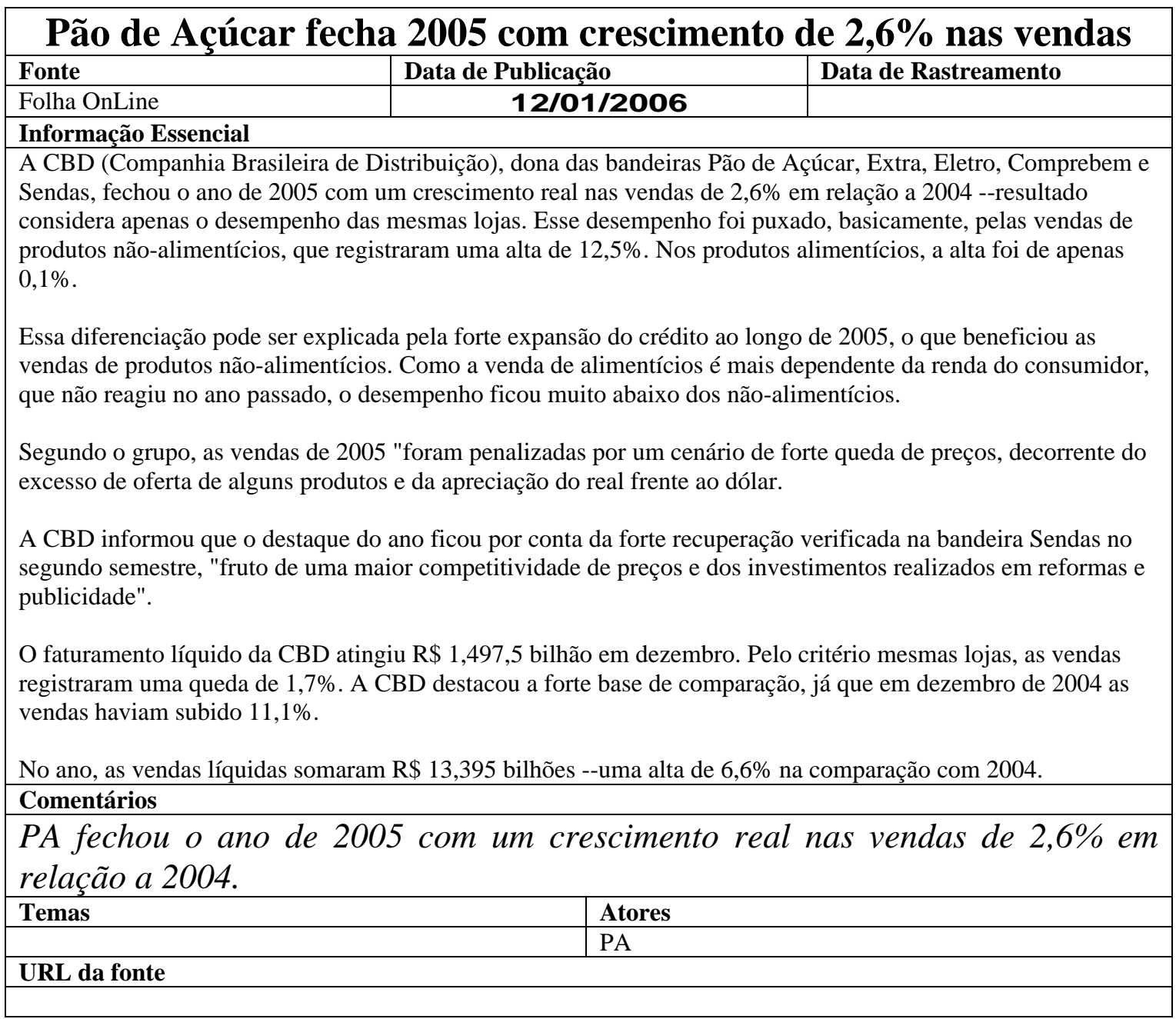




\begin{tabular}{|l|c|c|}
\hline Pão de Açúcar mantém liderança em ranking de supermercados pelo $3^{\circ}$ ano \\
\hline Fonte & Data de Publicação & Data de Rastreamento \\
\hline Folha OnLine & $\mathbf{1 2 / 0 4 / 2 0 0 6}$ & $31 / 08 / 2006$ \\
\hline Informação Essencial & & \\
\hline
\end{tabular}

O grupo Pão de Açúcar manteve em 2005, pelo terceiro ano consecutivo, a liderança no ranking anual de faturamento do setor, colocação que chegou a ser ocupada durante 13 anos pela rede francesa Carrefour ---desde 2003 está no segundo lugar.

O Wal-Mart continua em terceiro lugar, posição assumida já no ano passado, depois que o grupo comprou o Bompreço.

.....mesmo com a aquisição da rede Sonae o varejista norte-americano Wal-Mart permanecerá em terceiro lugar, embora encoste no Carrefour.

No ranking do último ano, o Sonae ainda aparece na quarta posição, separado do Wal-Mart, já que foi comprado pelo norte-americano no final de 2005.

Com a aquisição, o faturamento do gigante norte-americano vai aumentar de $\mathrm{R}$ \$ 7,099 bilhões para $\mathrm{R} \$ 11,7$ bilhões, mas não ultrapassará o do Carrefour (R \$ 12,5 bilhões). O faturamento nominal do Pão de Açúcar em 2005 foi de $\mathrm{R} \$ 15,8$ bilhões.

Lund avalia que o ritmo de aquisições no setor vai desacelerar. "Existem menos possibilidades de aquisições hoje. As empresas que ficaram têm um desempenho muito positivo, o que exigiria um desembolso muito maior de recursos [por parte dos compradores]", afirmou.

Para Lund, a competitividade entre as grandes redes vai permanecer, mas ao invés de focarem em aquisições elas devem anunciar planos agressivos de investimentos, principalmente nas regiões Nordeste e Centro-Oeste do país. Análise da Informação

PA mantém primeira posição do ranking pelo $3^{\circ}$ ano.

\begin{tabular}{|l|l|}
\hline Temas & Atores \\
\hline & WM, PA e CAR \\
\hline
\end{tabular}

URL da fonte

'http://www1.folha.uol.com.br/folha/dinheiro/ult91 $106813 . \mathrm{shtm}$ 


\section{8}

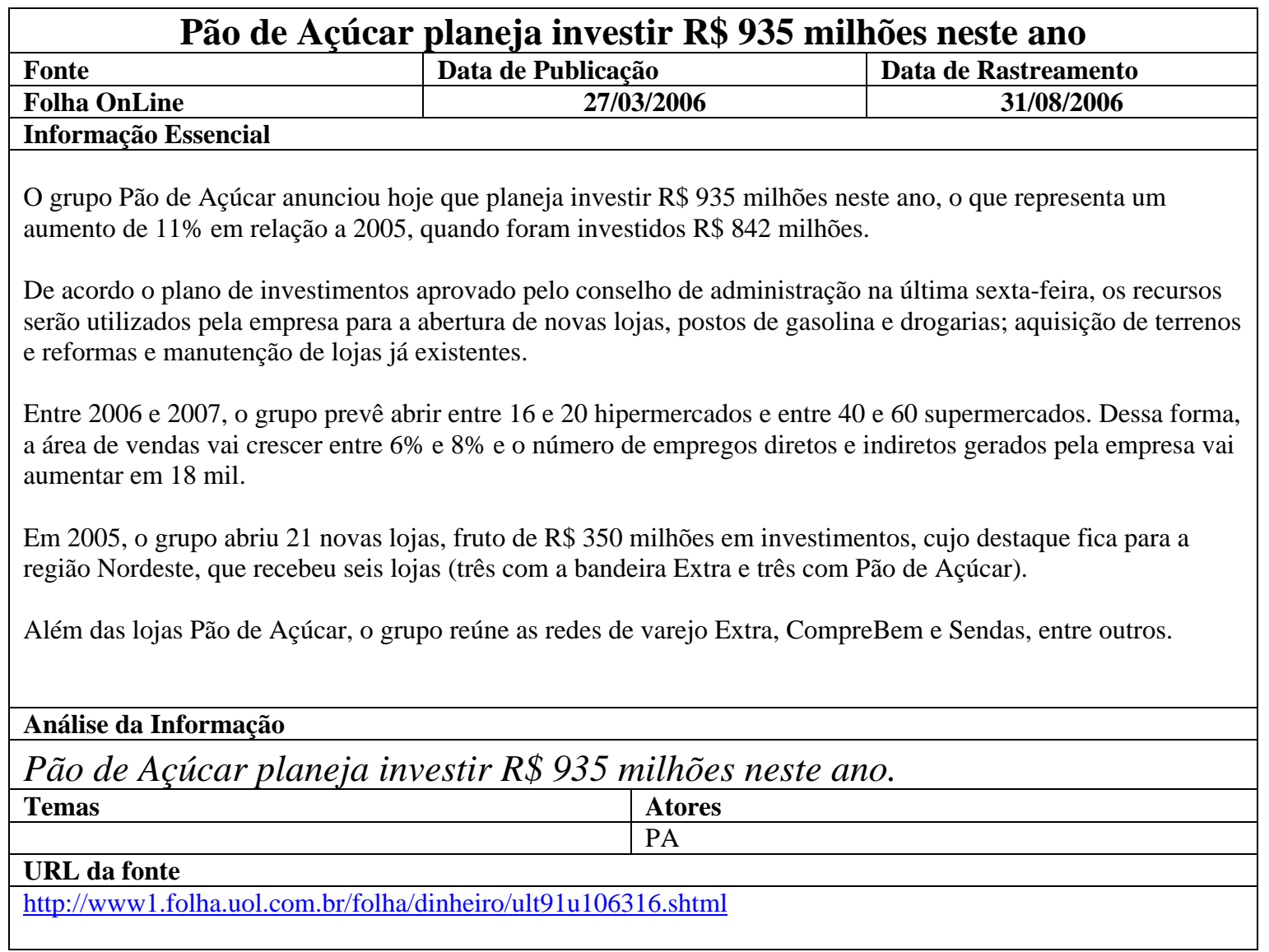




\begin{tabular}{|c|c|c|}
\hline \multicolumn{3}{|c|}{$\begin{array}{l}\text { Wal-Mart inaugura loja em Sorocaba e inicia disputa por vice- } \\
\text { lideranca }\end{array}$} \\
\hline Fonte & Data de Publicação & Data de Rastreamento \\
\hline Folha OnLine & $25 / 01 / 2006$ & \\
\hline \multicolumn{3}{|c|}{ Informação Essencial } \\
\hline \multicolumn{3}{|c|}{$\begin{array}{l}\text { O Wal-Mart inaugura amanhã a sua primeira loja em Sorocaba, que recebeu } \mathrm{R} \$ 40 \text { milhões em investimentos. } \\
\text { Com a nova filial, a rede varejista de origem norte-americana dá início à disputa pela vice-liderança do setor } \\
\text { supermercadista brasileiro. }\end{array}$} \\
\hline \multicolumn{3}{|c|}{$\begin{array}{l}\text { Para encostar no Carrefour, o Wal-Mart já anunciou que pretende gastar } \mathrm{R} \$ 600 \text { milhões neste ano para abrir } 15 \\
\text { novos pontos. Entre as novas lojas está a unidade de Franca (400 km de São Paulo), que deve ser inaugurada até } \\
\text { o final do ano. }\end{array}$} \\
\hline \multicolumn{3}{|c|}{$\begin{array}{l}\text { Mas os concorrentes não estão parados. O Carrefour informou que deve investir } \mathrm{R} \$ 700 \text { milhões na abertura de } \\
15 \text { lojas no país. O Pão de Açúcar pretende investir } R \$ 1,5 \text { bilhão no biênio } 2006 / 2007 \text { na abertura de } 16 \text { a } 20 \\
\text { hipermercados Extra e entre } 40 \text { a } 60 \text { supermercados (CompreBem, Pão de Açúcar ou Sendas). }\end{array}$} \\
\hline \multicolumn{3}{|c|}{$\begin{array}{l}\text { Pelas previsões do Wal-Mart, a cadeia americana fecharia o ano de } 2005 \text { com um faturamento de } \mathrm{R} \$ 11 \text { bilhões - } \\
\text {-já incluúdo o resultado do Sonae. O Pão de Açúcar registrou uma alta de } 5,4 \% \text { nas vendas brutas de } 2005 \text {, que } \\
\text { totalizaram } \mathrm{R} \$ 16,1 \text { bilhões. O Carrefour acumulou uma receita bruta de } \mathrm{R} \$ 11 \text { bilhões. }\end{array}$} \\
\hline \\
\hline \multicolumn{3}{|c|}{$\begin{array}{l}\text { O Wal-Mart inaugura amanhã a sua primeira loja em Sorocaba, que recebeu } \\
R \$ 40 \text { milhões em investimentos. A rede varejista dá início à disputa pela vice- } \\
\text { liderança do setor supermercadista brasileiro. }\end{array}$} \\
\hline \multicolumn{3}{|c|}{$\begin{array}{l}\text { O Carrefour informou que deve investir } R \$ 700 \text { milhões na abertura de } 15 \text { lojas } \\
\text { no país. } O \text { Pão de Açúcar pretende investir } R \$ 1,5 \text { bilhão no biênio 2006/2007 } \\
\text { na abertura de } 16 \text { a } 20 \text { hipermercados e entre } 40 \text { a } 60 \text { supermercados. }\end{array}$} \\
\hline Temas & \multicolumn{2}{|l|}{ Atores } \\
\hline \multicolumn{3}{|c|}{ 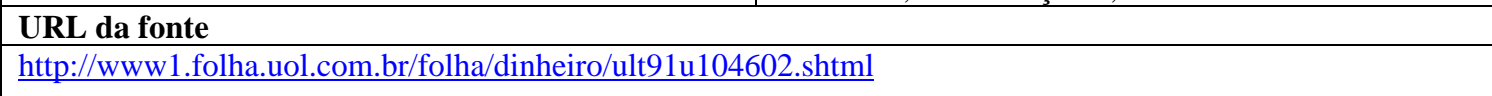 } \\
\hline
\end{tabular}




\begin{tabular}{|c|c|c|}
\hline \multicolumn{3}{|c|}{ Sonae quer comprar Portugal Telecom } \\
\hline Fonte & \multirow{2}{*}{$\begin{array}{l}\text { Data de Publicação } \\
07 / 02 / 2006\end{array}$} & Data de Rastreamento \\
\hline Folha OnLine & & \\
\hline \multicolumn{3}{|c|}{ Informação Essencial } \\
\hline \multicolumn{3}{|c|}{$\begin{array}{l}\text { O grupo português Sonae, por meio do Sonaecom, braço do setor de telecomunicações da empresa, fez ontem } \\
\text { uma oferta pública para a aquisição da Portugal Telecom, o maior grupo privado português, de maneira que ela } \\
\text { se torne dona de } 50,01 \% \text { do capital social da telefônica. }\end{array}$} \\
\hline \multicolumn{3}{|c|}{$\begin{array}{l}\text { A oferta pode não se transformar em negócio: a empresa colocou o plano na mesa, e cabe aos acionistas da PT } \\
\text { avaliar o caso. O governo português mantém uma "golden share" de } 500 \text { ações, que lhe dá poderes especiais na } \\
\text { empresa. }\end{array}$} \\
\hline \multicolumn{3}{|c|}{$\begin{array}{l}\text { Os brasileiros conhecem o Sonae porque a empresa, com atuação em vários ramos, tinha lojas de supermercados } \\
\text { no país (marca BIG), vendidas no ano passado ao Wal-Mart e ao Carrefour. A empresa ainda tem negócios na } \\
\text { área imobiliária e de turismo no Brasil. }\end{array}$} \\
\hline \multicolumn{3}{|c|}{$\begin{array}{l}\text { Já a Portugal Telecom tem negócios na área de comunicação e telefonia no Brasil. O grupo controla a operadora } \\
\text { de celulares Vivo e detém uma posição minoritária no UOL, controlado pela Folhapar, que publica a Folha. }\end{array}$} \\
\hline \multicolumn{3}{|c|}{$\begin{array}{l}\text { Um analista que não quis se identificar disse à agência Reuters que, se conseguir o controle da PT, o Sonae deve } \\
\text { vender alguns ativos, especialmente a brasileira Vivo. Segundo esse analista, um dos alvos principais da Sonae é } \\
\text { a PT Multimedia, a empresa de internet e televisão a cabo do grupo. }\end{array}$} \\
\hline \multicolumn{3}{|l|}{ Comentários } \\
\hline \multicolumn{3}{|c|}{$\begin{array}{l}\text { O grupo português Sonae, por meio do Sonaecom, braço do setor de } \\
\text { telecomunicações da empresa, fez ontem uma oferta pública para a aquisição } \\
\text { da Portugal Telecom, o maior grupo privado português. Um analista que não } \\
\text { quis se identificar disse à agência Reuters que, se conseguir o controle da PT, o } \\
\text { Sonae deve vender alguns ativos, especialmente a brasileira Vivo. }\end{array}$} \\
\hline \multirow[t]{2}{*}{ Temas } & & Atores \\
\hline & & \\
\hline \multicolumn{3}{|l|}{ URL da fonte } \\
\hline
\end{tabular}


51

\begin{tabular}{|c|c|c|}
\hline \multicolumn{3}{|c|}{ Supermercados demitem mais de 1.700} \\
\hline Fonte & Data de Publicação & Data de Rastreamento \\
\hline Folha OnLine & $06 / 06 / 2006$ & \\
\hline \multicolumn{3}{|c|}{ Informação Essencial } \\
\hline \multicolumn{3}{|c|}{$\begin{array}{l}\text { Nos cinco primeiros meses de 2006, incluindo no saldo as demissões de Wal-Mart e Carrefour, as grandes } \\
\text { cadeias de supermercados demitiram } 1.694 \text { trabalhadores até maio na capital --sendo } 1.064 \text { só no grupo Pão de } \\
\text { Açúcar. }\end{array}$} \\
\hline \multicolumn{3}{|c|}{$\begin{array}{l}\text { Nessa conta, também não estão incluídas eventuais demissões que o Wal-Mart pode ter feito no Sul do país em } \\
\text { 2006, após a aquisição da rede Sonae, em dezembro de } 2005 \text {. }\end{array}$} \\
\hline \multicolumn{3}{|c|}{$\begin{array}{l}\text { O Carrefour, também em reformulação de lojas neste ano, fechou } 26 \text { pontos da bandeira Champion em março } \\
\text { nos Estados de Minas Gerais, São Paulo, Espírito Santo e Distrito Federal. Na época, a empresa não havia } \\
\text { informado se os } 2.000 \text { funcionários das lojas seriam reaproveitados. Outras } 34 \text { lojas da empresa já se } \\
\text { transformaram, nos últimos dois meses, na bandeira "Carrefour Bairro". }\end{array}$} \\
\hline \multicolumn{3}{|c|}{$\begin{array}{l}\text { Como é um setor que demanda um volume elevado de mão-de-obra, o número de demitidos pelas cadeias } \\
\text { representa pouco do total. Pelas contas do sindicato, de } 1 \% \text { a } 2 \% \text { da mão-de-obra formal. No Pão de Açúcar os } \\
\text { mais de mil empregados dispensados representam } 1,7 \% \text { da força de trabalho do grupo em } 31 \text { de dezembro. }\end{array}$} \\
\hline \multicolumn{3}{|l|}{ Comentários } \\
\hline \multicolumn{3}{|c|}{ PA demite mais de $1000 \mathrm{em} 1700$ do setor. } \\
\hline \multirow[t]{2}{*}{ Temas } & Ator & \\
\hline & $\mathrm{PA}, \mathrm{C}$ & \\
\hline
\end{tabular}


52

\begin{tabular}{|c|c|c|}
\hline \multicolumn{3}{|c|}{ Veja raio-x da rede Sonae no Brasil, comprada hoje pelo Wal-Mart } \\
\hline Fonte & Data de Publicação & Data de Rastreamento \\
\hline Folha OnLine & \multirow{2}{*}{$14 / 12 / 2005$} & $31 / 08 / 2006$ \\
\hline \multicolumn{2}{|c|}{ Informação Essencial } & \\
\hline \multicolumn{3}{|c|}{$\begin{array}{l}\text { O grupo varejista português Sonae vendeu à rede americana Wal-Mart as } 140 \text { lojas que possuía no Brasil, nos } \\
\text { setores de hipermercados (bandeira Big), supermercados (bandeiras Mercadorama e Nacional) e de atacado } \\
\text { (bandeira Maxxi). }\end{array}$} \\
\hline \multicolumn{3}{|c|}{$\begin{array}{l}\text { A Sonae também possui postos de combustíveis, com a rede Big Posto, e os restaurantes Sabor Nacional e Big } \\
\text { Sabor (estes apenas no RS). }\end{array}$} \\
\hline \multicolumn{3}{|c|}{$\begin{array}{l}\text { Em parceria com a Unisinos (Universidade do Vale do Rio dos Sinos), do RS, a rede criou um curso superior de } \\
\text { gastronomia e, com a PUC, também no RS, criou uma empresa de desenvolvimento de software em Porto } \\
\text { Alegre, a Tlantic. }\end{array}$} \\
\hline \multicolumn{3}{|c|}{ Em 2004, a Sonae criou cerca de 23 mil empregos diretos e outros 8,2 mil indiretos. } \\
\hline \multicolumn{3}{|c|}{ Análise da Informação } \\
\hline \multicolumn{3}{|c|}{ Interesse WM na diversificação. } \\
\hline Temas & \multicolumn{2}{|c|}{ Atores } \\
\hline \multicolumn{3}{|l|}{ URL da fonte } \\
\hline
\end{tabular}


53

\begin{tabular}{|c|c|c|}
\hline \multicolumn{3}{|c|}{ Venda do Atacadão está em banho-maria } \\
\hline Fonte & Data de Publicação & Data de Rastreamento \\
\hline Folha OnLine & \multirow{2}{*}{ 03/07/2006 } & 31/08/2006 \\
\hline \multicolumn{2}{|c|}{ Informação Essencial } & \\
\hline \multicolumn{3}{|c|}{$\begin{array}{l}\text { O temor de que a compra do Atacadão se transforme numa dor de cabeça tributária colocou a negociação da } \\
\text { venda da rede em banho-maria, segundo apurou a Folha. Pão de Açúcar, Carrefour, Wal-Mart e Makro já } \\
\text { visitaram o "data room" (sala de informações) da empresa para levantar dados da rede, que opera numa mistura } \\
\text { de atacado e varejo. }\end{array}$} \\
\hline \multicolumn{3}{|c|}{$\begin{array}{l}\text { A rede é a maior atacadista no país, fatura } \mathrm{R} \$ 4,5 \text { bilhões e tem } 35 \text { lojas. "A empresa em questão, por várias } \\
\text { vezes, foi acionada para prestar esclarecimentos sobre o assunto em pauta". A secretaria não informa se houve } \\
\text { autuação porque trata-se de processo sigiloso. }\end{array}$} \\
\hline \multicolumn{3}{|c|}{$\begin{array}{l}\text { Após uma boa olhada nos números, a dúvida dos interessados está nos benefícios fiscais que a companhia } \\
\text { adquiriu, e que correm o risco de ser questionados pelo fisco após a compra da cadeia de atacado. As empresas } \\
\text { fazem as contas agora para saber qual a situação jurídica da cadeia de } 35 \text { lojas. }\end{array}$} \\
\hline \multicolumn{3}{|c|}{$\begin{array}{l}\text { O tamanho do crédito fiscal que a rede tem poderá ser descontado do preço de venda da operação do Atacadão se } \\
\text { o comprador adotar uma postura mais conservadora --e acreditar que essa vantagem fiscal será questionada na } \\
\text { Justiça. }\end{array}$} \\
\hline \multicolumn{3}{|c|}{$\begin{array}{l}\text { A compra do Atacadão poderá fazer a rede Wal-Mart ( } \mathrm{R} \$ 11,7 \text { bilhões de faturamento bruto) encostar no grupo } \\
\text { Pão de Açúcar ( } \mathrm{R} \$ 16,6 \text { bilhões) e ultrapassar o Carrefour ( } \mathrm{R} \$ 12,5 \text { bilhões) no ranking de supermercados. Ao } \\
\text { mesmo tempo, pode levar o Pão de Açúcar a se consolidar como a maior cadeia do setor no Brasil. As análises } \\
\text { ainda estão sendo feitas e não há favoritos, apenas rumores de mercado. }\end{array}$} \\
\hline \multicolumn{3}{|c|}{ Análise da Informação } \\
\hline \multicolumn{3}{|c|}{$\begin{array}{l}\text { Esta informação reforça o sinal apontado pela informação - } 009 \text { (Wal-Mart, Pão de Açúcar } \\
\text { e Carrefour estão na reta final pelo Atacadão) da apreensão em relação à aquisição da rede } \\
\text { Atacadão, devido ao temor de "uma dor de cabeça tributária" por parte dos envolvidos no } \\
\text { processo. }\end{array}$} \\
\hline \multicolumn{3}{|c|}{ Atores } \\
\hline \\
\hline
\end{tabular}




\section{4}

\begin{tabular}{|l|c|c|}
\hline \multicolumn{3}{|c|}{ Vendas de supermercados caem 1,5\% em fevereiro, diz Abras } \\
\hline Fonte & Data de Publicação & Data de Rastreamento \\
\hline Folha OnLine & $21 / 03 / 2006$ & \\
\hline Informação Essencial & & \\
\hline
\end{tabular}

As vendas reais no setor supermercadista registraram queda de 1,5\% em fevereiro em relação ao mesmo mês do ano passado, informou nesta terça-feira a Abras (Associação Brasileira de Supermercados).

Na comparação com janeiro deste ano, a queda foi maior, de $4,31 \%$.

Apesar de as vendas do setor continuarem apresentando queda em fevereiro e, levando em conta a sazonalidade própria do mês, o desempenho negativo ainda foi mais ameno que o de janeiro, que chegou a $2,16 \%$.

O presidente da Abras, João Carlos de Oliveira ... avaliou que em 2005, o setor obteve "um crescimento muito positivo", exatamente por causa da gordura do volume apresentado no primeiro trimestre do ano.

Nos três primeiros meses de 2005, o setor acumulou crescimento de 8,63\%. O acumulado desse ano até o mês passado ficou negativo em $1,84 \%$.

Entre os motivos que explicariam esse futuro incremento nas vendas do setor supermercadista em 2006 está o anúncio do governo sobre o baixo índice de desemprego, a queda na taxa de juros, a nova tabela do imposto de renda e o aumento significativo de $18 \%$ do salário mínimo.

A expansão do setor, com a chegada das três maiores redes de supermercados (Carrefour, Wal-Mart e Pão-deAçúcar) às regiões Nordeste e Centro-Oeste do país, seria outro fator favorável para índices positivos.

\section{Comentários}

Vendas nos supermercados caem $4,3 \%$ em janeiro e $1,5 \%$ em fevereira, comparativamente aos mesmos meses de 2005.

\begin{tabular}{|l|l|}
\hline Temas & Atores \\
\hline & Setor supermercadista, PA, CAR, WM \\
\hline URL da fonte & \\
\hline
\end{tabular}




\section{5}

\section{Vendas do Grupo Pão de Açúcar crescem 3,6\%, a R\$ 1,255 bi, em junho}

\begin{tabular}{|l|c|c|}
\hline Fonte & Data de Publicação & Data de Rastreamento \\
\hline Folha OnLine & \multicolumn{1}{|c|}{$\mathbf{1 3 / 0 7 / 2 0 0 6}$} & \\
\hline Informação Essencial & \multicolumn{2}{|c|}{$\begin{array}{l}\text { As vendas brutas do Grupo Pão de Açúcar --que incluem as lojas CompreBem, Extra e Sendas-- cresceram 3,6\% } \\
\text { em junho na comparação com o mesmo período de 2005...O resultado foi puxado pela categoria de não- } \\
\text { alimentos, principalmente eletroeletrônicos. As vendas de gêneros alimentícios apresentaram ligeira recuperação } \\
\text { em junho, mas continuam em queda, devido ao efeito do câmbio e da deflação em alguns produtos. }\end{array}$} \\
$\begin{array}{l}\text { O Grupo Pão de Açúcar cita ainda a Copa do Mundo, o aumento do salário mínimo a partir de maio e sua } \\
\text { estratégia de ter preços mais competitivos em busca de competitividade como fatores que contribuíram para o } \\
\text { aumento das vendas. }\end{array}$ \\
\hline Comentários \\
\hline $\begin{array}{l}\text { Vendas PA crescem 3,5\% em junho em relação 2005, puxado pelos não- } \\
\text { alimentos. }\end{array}$ \\
\hline Temas & Atores \\
\hline URL da fonte & PA \\
\hline
\end{tabular}


56

\section{Vendas nos supermercados avançam $0,66 \%$ e atingem $R \$ 105$ bi em 2005}

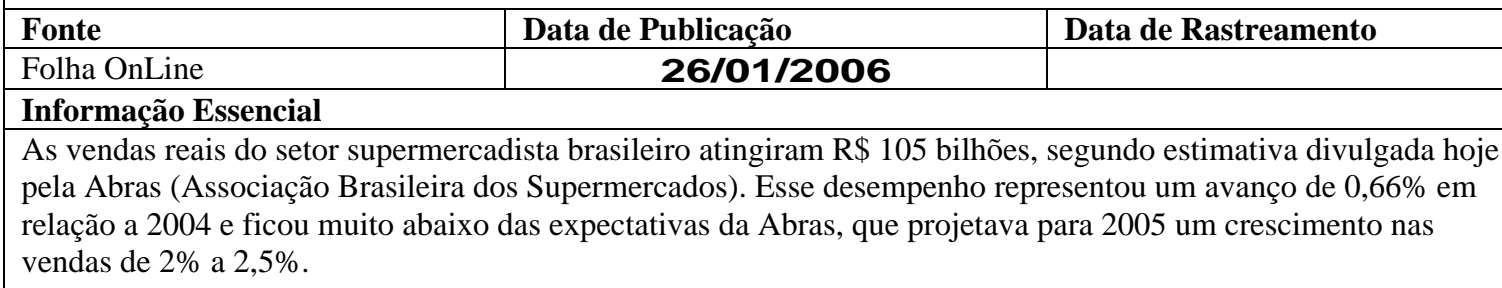

O resultado aquém do esperado pode ser explicado por fatores atípicos, como a queda de 3,84\% nas vendas de dezembro, mês em que sazonalmente o faturamento deveria subir por conta do Natal e Ano Novo. Esse comportamento negativo foi iniciado em abril e manteve presente no restante de 2005, segundo a Abras.

O presidente da Abras, João Carlos de Oliveira, também atribui o péssimo resultado de 2005 à política de juros altas combinada ao desemprego elevado e renda comprimida. "Tínhamos uma expectativa, que não se confirmou, que o início da queda dos juros iria criar um clima favorável ao consumo", disse ele.

Além disso, a expansão do crédito consignado --com desconto direto no holerite-- elevou o nível de endividamento da população e reduziu a renda disponível para o consumo nos supermercados. "Num mercado retraído, em que os consumidores vão empurrando as dívidas e contraindo novas dívidas, o crédito consignado acaba afetando o poder futuro de compra a população", afirmou Oliveira.

Outro fator detectado pela Abras foi a mudança de hábito do consumidor, que voltou a substituir produtos de primeira marca por outros mais baratos. "O consumidor preferiu o panetone mais barato à marca mais conhecida. Em vez de vinhos europeus, comprou produtos da América do Sul, que são mais baratos", disse o presidente da Abras.

A depreciação do dólar também contribuiu para a redução da receita dos supermercados com a venda de produtos importados. Em dezembro, por exemplo, a venda de importados cresceu 17,5\% em volume, mas em receita a expansão foi de apenas $6 \%$. "A depreciação do dólar reduziu o preço dos importados. E o aumento das vendas em volume não foi significante para a receita do setor", afirmou Oliveira.

\section{Projeções}

Para 2006, a Abras espera por um incremento nas vendas do setor supermercadista 2,5\%. "Esperamos pela repetição do ano de 2004, que recuperou parte das perdas de 2003. Se ocorrer o mesmo, 2006 recuperará parte do resultado que não foi alcançado em 2005", disse Oliveira.

Essa projeção se sustenta nos investimentos das redes supermercadistas na expansão do número de lojas. Pelos cálculos da Abras, o crescimento físico do setor é da ordem de $8 \%$ a $10 \%$ ao ano. Os três maiores grupos --Pão de Açúcar, Carrefour e Wal-Mart-- anunciaram investimentos de R \$2,8 bilhões na abertura de lojas.

O gigante norte-americano Wal-Mart, que em 2005 comprou a rede Sonae, pretende gastar R \$ 600 milhões neste ano para abrir 15 novos pontos. O Carrefour informou que deve investir R\$ 700 milhões na abertura de 15 lojas. O Pão de Açúcar anunciou que vai investir R\$ 1,5 bilhão no biênio 2006/2007 na abertura de 16 a 20 hipermercados Extra e entre 40 a 60 supermercados (CompreBem, Pão de Açúcar ou Sendas). O grupo não especificou quanto desse montante será aplicado em 2006.

\section{Comentários}

Vendas reais em 2005 dos supermercados teve alta de 0,66\% em relação a 2004.

\begin{tabular}{|l|l|}
\hline Temas & Atores \\
\hline & M. Supermercadista, PA, CAR, WM \\
\hline
\end{tabular}

\section{URL da fonte}




\begin{tabular}{|c|c|c|}
\hline \multicolumn{3}{|c|}{ Pão de Açúcar pretende investir R\$ 1,5 bi até 2007 para ampliar rede } \\
\hline Fonte & Data de Publicação & Data de Rastreamento \\
\hline Folha OnLine & \multirow[t]{2}{*}{ 12/01/06 } & $31 / 08 / 2006$ \\
\hline \multicolumn{2}{|c|}{ Informação Essencial } & \\
\hline \multicolumn{3}{|c|}{$\begin{array}{l}\text { A CBD (Companhia Brasileira de Distribuição), dona das bandeiras Pão de Açúcar, Extra Eletro, Comprebem e } \\
\text { Sendas, pretende investir R } \$ 1,5 \text { bilhão no biênio 2006-2007 para ampliação de sua rede supermercadista. Os } \\
\text { recursos serão direcionados, principalmente, para a abertura de } 16 \text { a } 20 \text { hipermercados e de } 40 \text { a } 60 \\
\text { supermercados. }\end{array}$} \\
\hline \multicolumn{3}{|c|}{$\begin{array}{l}\text { Até setembro, a CBD contava com } 555 \text { pontos de venda no país: } 185 \text { supermercados Pão de Açúcar, } 75 \\
\text { hipermercados Extra, } 179 \text { lojas da bandeira Comprebem, } 50 \text { Extra Eletro e } 66 \text { unidades da bandeira Sendas. }\end{array}$} \\
\hline \multicolumn{3}{|c|}{$\begin{array}{l}\text { Segundo a CBD, essa expansão permitirá ao grupo um aumento anual médio da área de vendas entre } 6 \% \text { e } 8 \% \text {. } \\
\text { O Grupo Pão de Açúcar informou que esses investimentos fazem parte do seu plano de crescer organicamente, } \\
\text { que ainda precisará ser aprovado pelo conselho de administração da CBD. }\end{array}$} \\
\hline \multicolumn{3}{|c|}{$\begin{array}{l}\text { Em nota divulgada ao mercado, a CBD informa que o principal foco para o biênio 2006-2007 é o aumento da sua } \\
\text { eficiência operacional, competitividade e lucratividade. }\end{array}$} \\
\hline \multicolumn{3}{|c|}{$\begin{array}{l}\text { Para alcançar essas metas, a companhia já deu andamento a algumas ações, como a revisão do modelo de gestão, } \\
\text { de processos e de sistemas relacionados a compras e gerenciamento de categorias. O objetivo é ganhar eficiência } \\
\text { nas negociações com fornecedores, na definição do sortimento e de estratégias de preço, nas promoções e na } \\
\text { exposição dos produtos nas lojas. }\end{array}$} \\
\hline \multicolumn{3}{|c|}{$\begin{array}{l}\text { Outras ações em andamento são o chamado projeto "Orçamento Base Zero"; centralização de serviços internos; } \\
\text { criação da área de suprimentos e serviços que centralizará a compra de produtos e serviços não destinados à } \\
\text { venda; entre outras. }\end{array}$} \\
\hline \multicolumn{3}{|c|}{$\begin{array}{l}\text { "Os ganhos de eficiência que esperamos obter com essas iniciativas serão gradualmente reinvestidos em menores } \\
\text { preços para os consumidores, nos possibilitando aumentar o tráfego de clientes nas nossas lojas, ganhar volume } \\
\text { e, conseqüentemente, aumentar vendas mesmas lojas, que é o caminho mais eficaz para alcançarmos níveis mais } \\
\text { elevados de retornos sobre o capital investido", diz a CBD em nota divulgada ao mercado. }\end{array}$} \\
\hline \multicolumn{3}{|c|}{$\begin{array}{l}\text { O grupo informa que espera obter em } 2006 \text { margens operacionais semelhantes às registradas em } 2005 \text {, "porém } \\
\text { com patamares mais elevados de vendas mesmas lojas, que esperamos significar um crescimento acima da } \\
\text { inflação projetada para o ano". }\end{array}$} \\
\hline \multicolumn{3}{|c|}{$\begin{array}{l}\text { A CBD fechou o ano de } 2005 \text { com um crescimento real nas vendas de } 2,6 \% \text { em relação a } 2004 \text {--resultado } \\
\text { considera apenas o desempenho das mesmas lojas. Esse desempenho foi puxado, basicamente, pelas vendas de } \\
\text { produtos não-alimentícios, que registraram uma alta de } 12,5 \% \text {. Nos produtos alimentícios, a alta foi de apenas } \\
0,1 \% \text {. }\end{array}$} \\
\hline \multicolumn{3}{|c|}{ Análise da Informação } \\
\hline \multicolumn{3}{|c|}{$\begin{array}{l}\text { Pretende investir } R \$ 1,5 \text { bilhão no biênio 2006-2007 para ampliação de sua } \\
\text { rede supermercadista. Foco para o biênio é o aumento da sua eficiência } \\
\text { operacional, competitividade e lucratividade. }\end{array}$} \\
\hline \multirow[t]{2}{*}{ Temas } & Ator & \\
\hline & & \\
\hline \multicolumn{3}{|l|}{ URL da fonte } \\
\hline & & \\
\hline
\end{tabular}




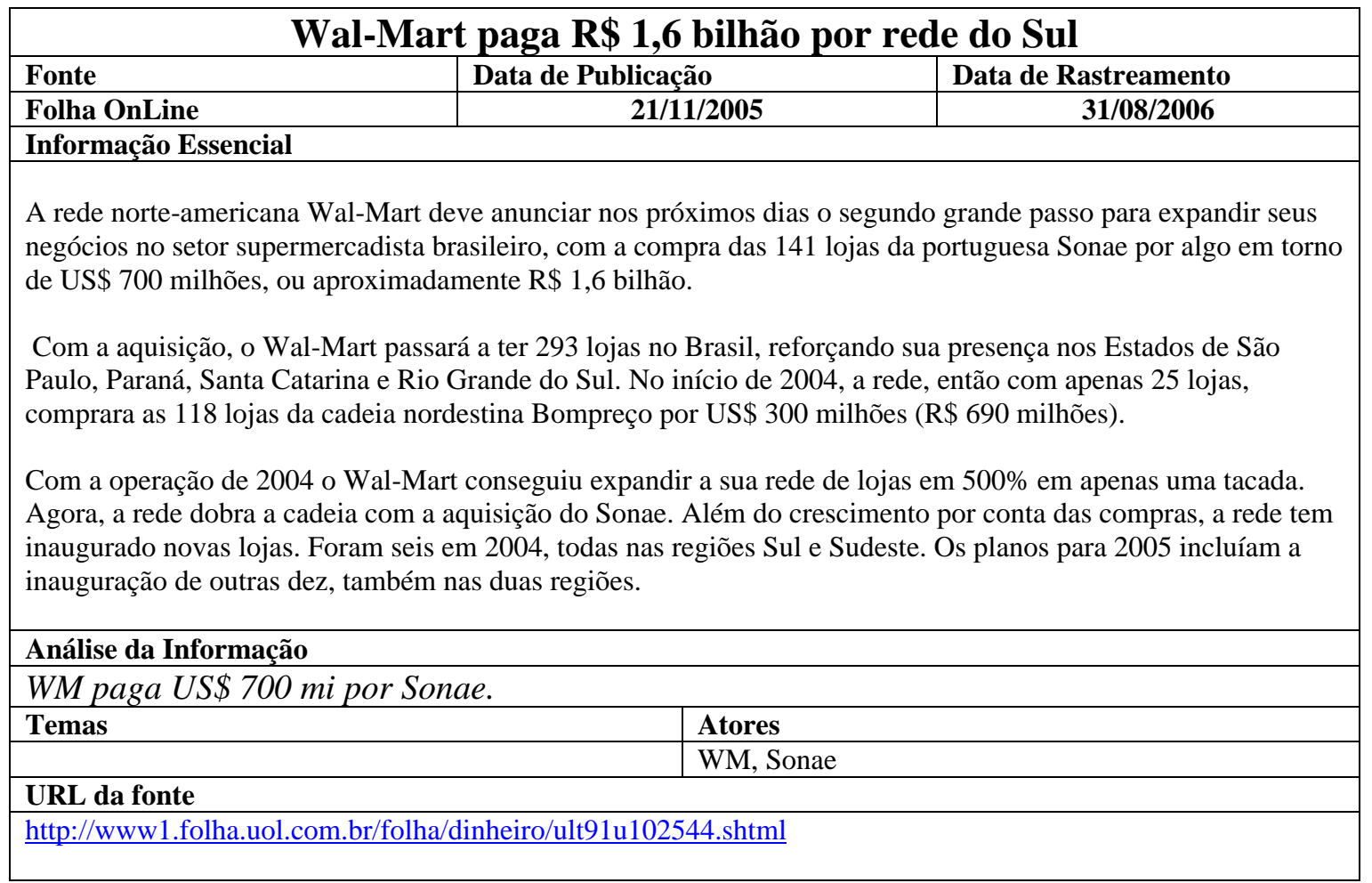




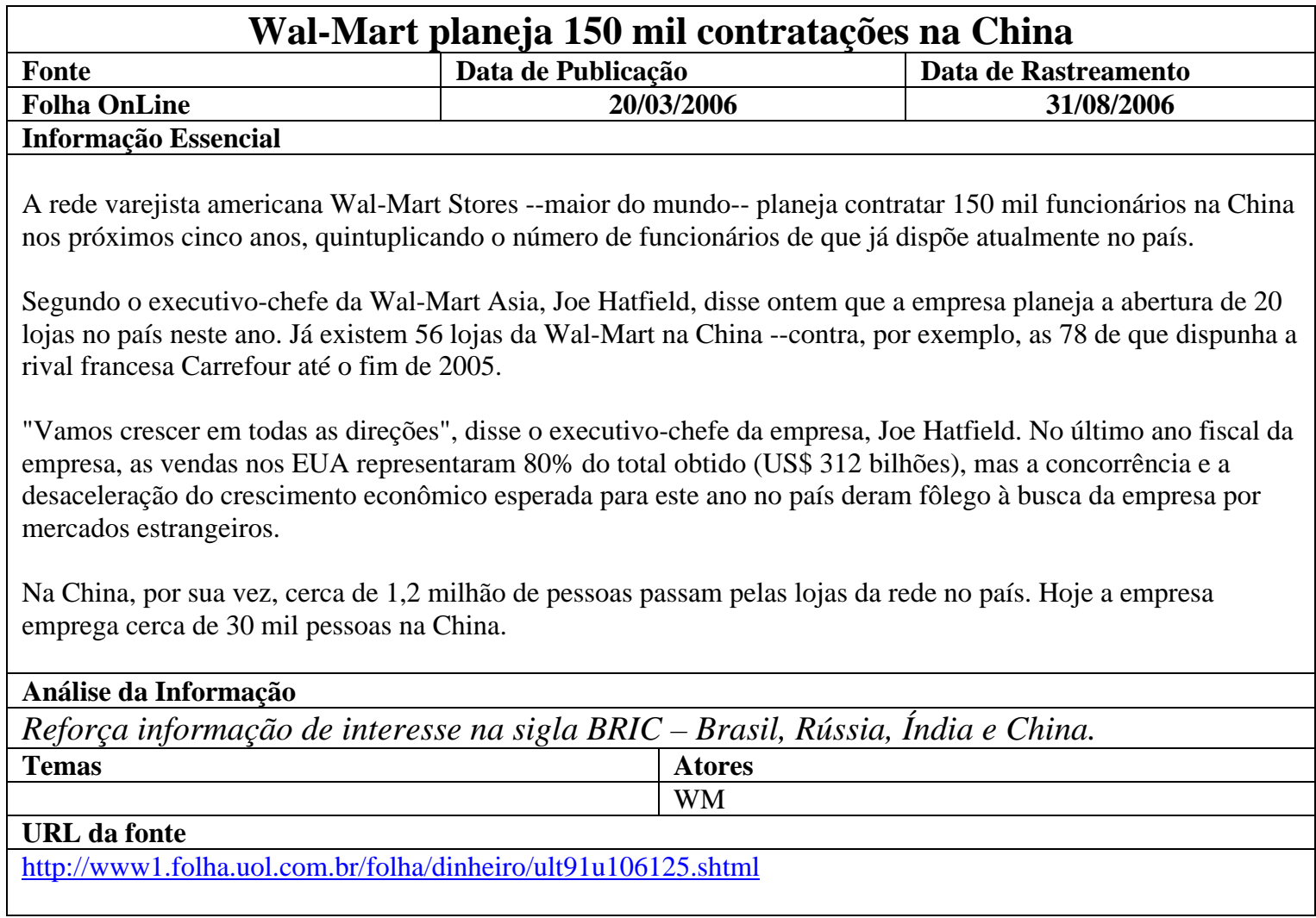


60

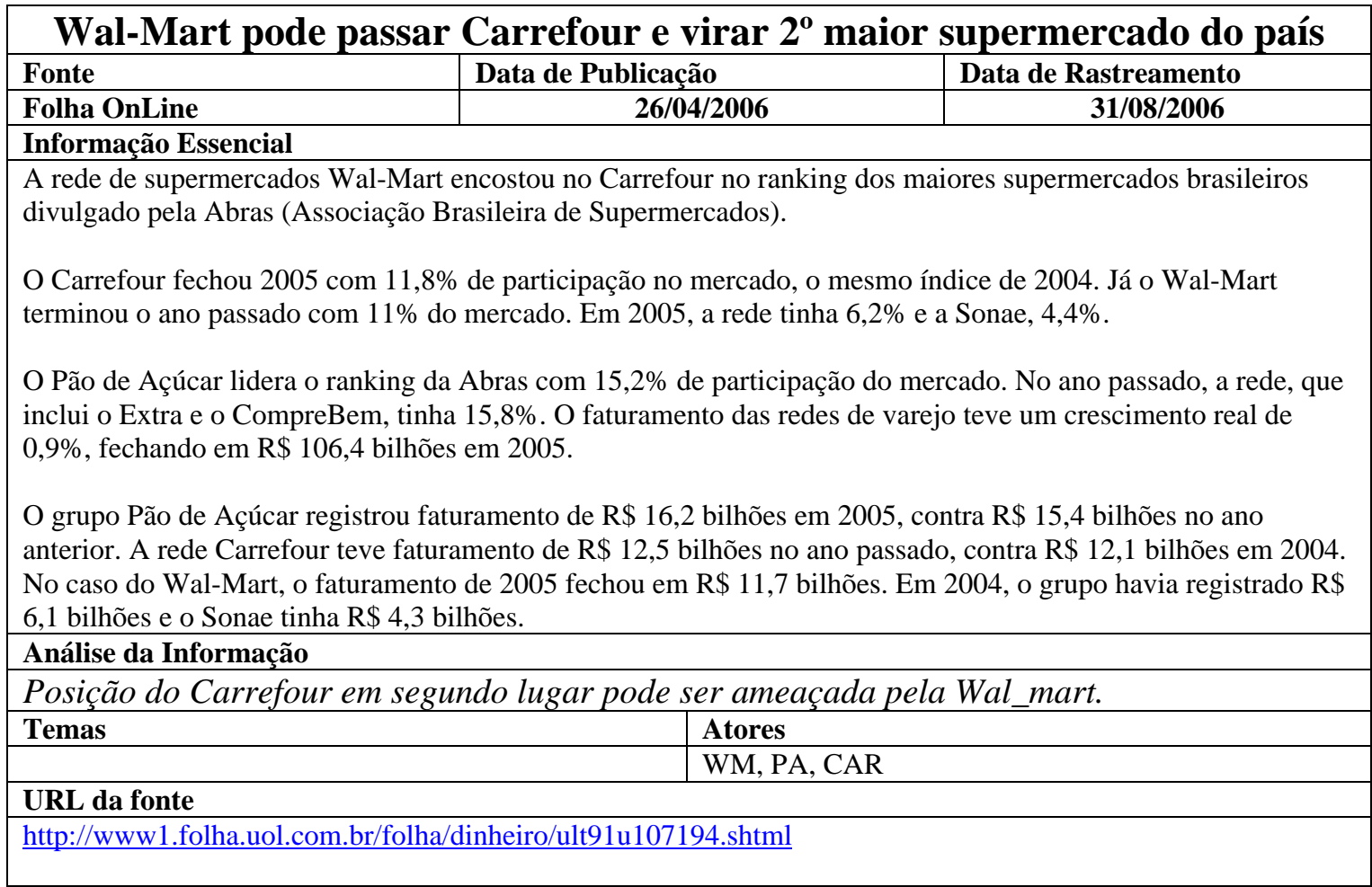


61

\begin{tabular}{|c|c|c|}
\hline \multicolumn{3}{|c|}{ Wal-Mart traça plano para dominar varejo brasileiro } \\
\hline Fonte & \multirow{2}{*}{ Data de Publicação } & Data de Rastreamento \\
\hline Folha OnLine & & 31/08/2006 \\
\hline \multicolumn{3}{|c|}{ Informação Essencial } \\
\hline \multicolumn{3}{|c|}{$\begin{array}{l}\text { Em reunião fechada na sede do grupo Wal-Mart, nos EUA, em junho, a operação brasileira foi alvo de um } \\
\text { relatório interno sigiloso elaborado pelo comando da maior rede de varejo do mundo. Um dos tópicos é uma } \\
\text { bomba: prevê faturamento no país de } R \$ 40 \text { bilhões (valor nominal) daqui a dez anos, apurou a Folha. Trazido a } \\
\text { valor presente (número real), segundo cálculo de analista, seriam } R \$ 27 \text { bilhões --o equivalente à soma da receita } \\
\text { da cadeia americana e do grupo Pão de Açúcar em } 2005 \text {. }\end{array}$} \\
\hline \multicolumn{3}{|c|}{$\begin{array}{l}\text { Os R } \$ 27 \text { bilhões (valor presente) equivalem a pouco mais de } 25 \% \text { de participação de mercado nas vendas do } \\
\text { segmento supermercadista no país. As duas maiores redes no Brasil hoje, Pão de Açúcar e a francesa Carrefour, } \\
\text { têm um "market share" de pouco mais de } 14 \% \text { e } 11 \% \text {, respectivamente. }\end{array}$} \\
\hline \multirow{2}{*}{\multicolumn{3}{|c|}{$\begin{array}{l}\text { Se conseguir atingir os R } \$ 27 \text { bilhões, será uma expansão média real anual, até } 2016 \text {, de } 8,73 \% \text {--muito superior } \\
\text { à taxa de crescimento do setor nos últimos anos, assim como a prevista para os próximos dez anos. O } \\
\text { desempenho dos supermercados acompanha a expansão do PIB nacional, que deverá crescer } 4 \% \text { ao ano, em } \\
\text { média, de } 2006 \text { a } 2011 \text {, e outros } 4,5 \% \text { de } 2011 \text { a } 2016 \text {, segundo estimava média de corretoras e bancos de varejo. } \\
\text { É possível inferir, portanto, que uma expansão nesse patamar de quase } 9 \% \text { só será possível roubando mercado } \\
\text { alheio, dizem especialistas. Seja por um veloz crescimento orgânico ou por aquisiçôes. É nesse segundo caso } \\
\text { que o crescimento pode ser mais rápido. }\end{array}$}} \\
\hline & & \\
\hline \multicolumn{3}{|c|}{$\begin{array}{l}\text { Recursos para o "bote" do Wal-Mart não faltam. Além de ser a maior varejista do mundo, a rede admite } \\
\text { abertamente que analisa todas as possibilidade de compra no país e tem dinheiro de sobra. }\end{array}$} \\
\hline \multicolumn{3}{|c|}{$\begin{array}{l}\text { Foi o Wal-Mart, com faturamento que já ultrapassa os US\$ } 300 \text { bilhões anuais no mundo, que assinou o cheque } \\
\text { de US\$ } 763,7 \text { milhões para a compra da rede portuguesa Sonae no Brasil, em } 2005 .\end{array}$} \\
\hline \multicolumn{3}{|c|}{ Análise da Informação } \\
\hline \multicolumn{3}{|c|}{$\begin{array}{l}\text { Wal-Mart prevê, em reunião fechada nos EUA, faturamento no Brasil daqui há dez anos de } \\
\text { US\$ } 40 \text { bi (US\$ } 27 \text { bi trazidos a valor presente). Considerando-se os valores faturados das } 3 \\
\text { primeiras do ranking ABRAS no ano de } 2005 \text { e um market share respectivamente de } 15 \% \\
\text { (Pão de Açúcar), } 12 \% \text { (Carrefour) e } 11 \% \text { (Wal-Mart), este número é bastante significativo. } \\
\text { Pode representar } 25 \% \text { do market share total em 2016. Sinal importante para a avaliação de } \\
\text { futuros investimentos da área supermercadista no Brasil. }\end{array}$} \\
\hline \multicolumn{3}{|c|}{$\begin{array}{l}\text { A sigla BRIC - Brasil, Rússia, Índia e China - mercados com maior potencial de expansão e } \\
\text { crescimento nos próximos tempos e de maior interesse de investimento da área do comércio } \\
\text { varejista mundial. }\end{array}$} \\
\hline \multirow[t]{2}{*}{ Temas } & Atores & \\
\hline & $\overline{\mathrm{WM}}$ & \\
\hline
\end{tabular}




\section{2}

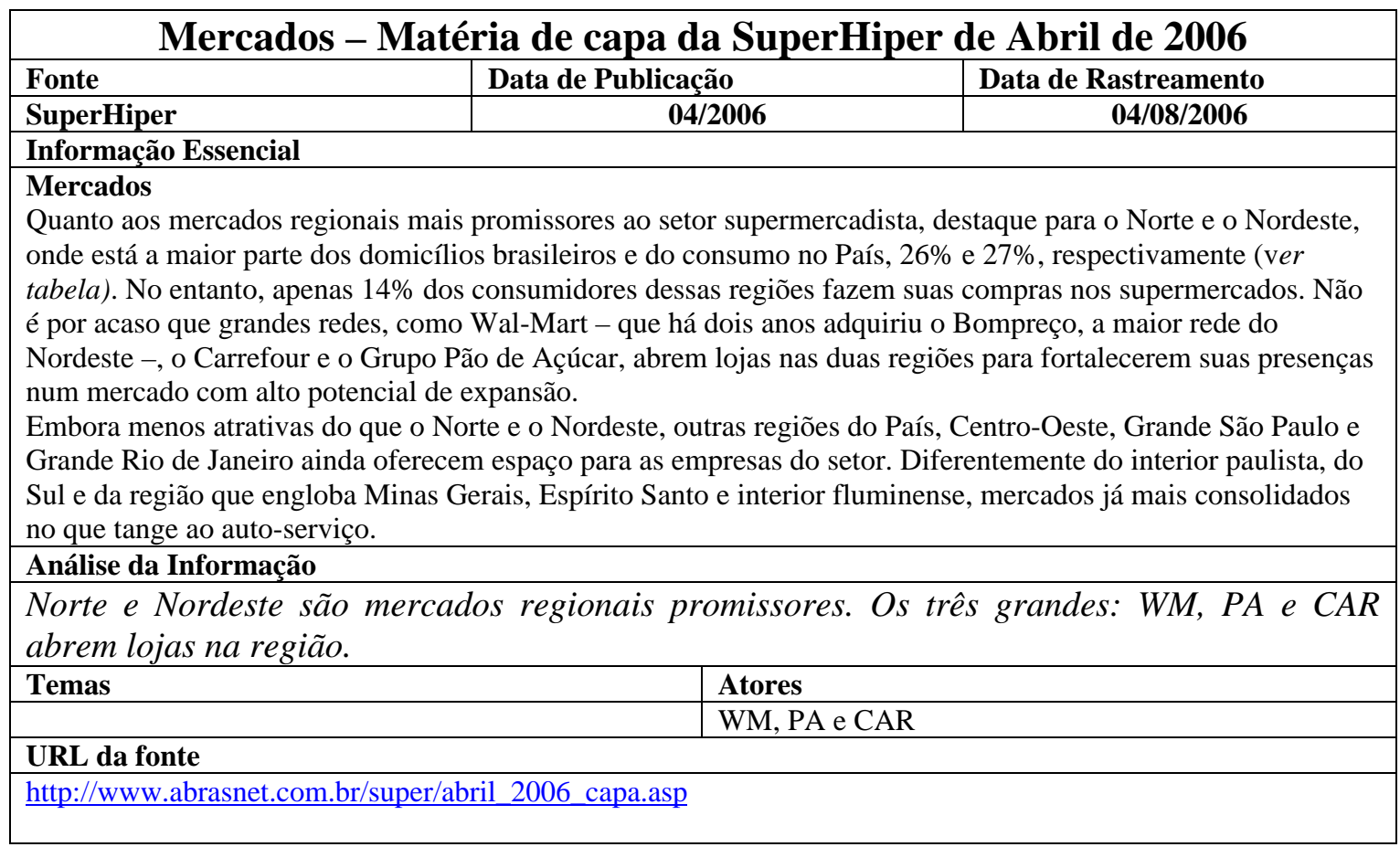


63

\begin{tabular}{|c|c|c|}
\hline \multicolumn{3}{|c|}{ Perspectivas - Matéria de capa da SuperHiper de Dezembro de 2005} \\
\hline Fonte & \multirow{2}{*}{$\begin{array}{r}\text { Data de Publicação } \\
12 / 2005\end{array}$} & Data de Rastreamento \\
\hline SuperHiper & & 006 \\
\hline \multicolumn{3}{|c|}{ Informacão Essencial } \\
\hline \multicolumn{3}{|c|}{$\begin{array}{l}\text { Assim o setor consegue crescer e expandir como aconteceu na virada do ano, quando várias redes inauguraram } \\
\text { lojas em todo o Brasil, de olho nas oportunidades de vendas no período do Natal e visando aos negócios durante } \\
\text { todo este ano de } 2006 \text {. } \\
\text { Nas grandes, especialmente as cinco maiores pelo Ranking Abras, a concorrência deve se acirrar este ano, } \\
\text { ativada por aquisições entre elas, por exemplo a compra da rede Sonae pelo Wal-Mart. Os primeiros colocados } \\
\text { do Ranking Abras - a Companhia Brasileira de Distribuição (CBD), amparada pelo suporte financeiro do } \\
\text { Casino; o Carrefour, que em } 2005 \text { se reestruturou, desenvolvendo até mesmo outros modelos de loja; e o Wal- } \\
\text { Mart, que bem demonstrou seu ímpeto de crescimento com a aquisição da rede Bompreço em } 2004 \text { e a recente } \\
\text { compra do Sonae - devem abrir uma temporada bem intensa de investimentos em } 2006 \text {. }\end{array}$} \\
\hline \multicolumn{3}{|c|}{ Análise da Informação } \\
\hline \multicolumn{3}{|c|}{$\begin{array}{l}\text { A CBD, amparada pelo suporte financeiro do Casino; o Carrefour, que em } 2005 \\
\text { se reestruturou, desenvolvendo até mesmo outros modelos de loja; e o Wal- } \\
\text { Mart, que bem demonstrou seu ímpeto de crescimento com a aquisiçấo da rede } \\
\text { Bompreço em } 2004 \text { e a recente compra do Sonae - devem abrir uma temporada } \\
\text { bem intensa de investimentos em } 2006 \text {. }\end{array}$} \\
\hline \multicolumn{3}{|c|}{$\begin{array}{l}\text { Nas grandes, especialmente as cinco maiores pelo Ranking Abras, a } \\
\text { concorrência deve se acirrar este ano, ativada por aquisiçôes entre elas. }\end{array}$} \\
\hline \multirow[t]{2}{*}{ Tema } & & \\
\hline & & \\
\hline \multicolumn{3}{|l|}{ URL da fonte } \\
\hline \multicolumn{3}{|c|}{ dezembro 2005 capa.asd } \\
\hline
\end{tabular}




\section{4}

\begin{tabular}{|c|c|c|}
\hline \multicolumn{3}{|c|}{ Concentração - Matéria de capa da SuperHiper de Maio de 2006} \\
\hline Fonte & Data de Publicação & Data de Rastreamento \\
\hline SuperHiper & \multirow[t]{2}{*}{$05 / 2006$} & 04/08/2006 \\
\hline \multicolumn{2}{|c|}{ Informação Essencial } & \\
\hline \multicolumn{3}{|c|}{$\begin{array}{l}\text { Concentração } \\
\text { Apesar da manutenção das cinco primeiras empresas do setor em termos de percen- } \\
\text { tual de faturamento, com } 40 \% \text { de participação, percebe-se no quadro uma melhora significativa das outras } \\
\text { empresas que compõem o grupo das } 50 \text { maiores. Em } 2005 \text {, a grande mudança ocorrida foi a ascensão do } \\
\text { faturamento da rede Wal-Mart, a maior varejista do mundo, que adquiriu a operação da rede Sonae, com mais de } \\
400 \text { lojas no Sul do País. Com o acréscimo do faturamento da Sonae, que em } 2004 \text { foi de } \mathrm{R} \$ 4,3 \text { bilhões, o Wal- } \\
\text { Mart ampliou sua presença no setor e praticamente encostou no segundo colocado do Ranking, o Carrefour. } \\
\text { A saída da Sonae, que estava na quarta posição no ano passado, fez a rede G. Barbosa subir um posto, } \\
\text { participando agora do grupo das cinco maiores redes do Brasil. }\end{array}$} \\
\hline \multicolumn{3}{|c|}{$\begin{array}{l}\text { Segundo o consultor da Abras Antonio Carlos Ascar, dentro deste cenário é possível verificar que } \\
\text { principalmente as três primeiras colocadas tiveram índices de crescimento menores, registrando até queda no } \\
\text { faturamento real, se comparado com as empresas com faturamento na casa de } \mathrm{R} \$ 1 \text { bilhão. }\end{array}$} \\
\hline \multicolumn{3}{|c|}{$\begin{array}{l}\text { Por exemplo, partindo da quarta posição, a Cia. Zaffari cresceu nominalmente mais de } 11 \% \text {; a sergipana G. } \\
\text { Barbosa, quinta colocada, cresceu } 19 \% \text {, enquanto a primeira do Ranking, a Companhia Brasileira de } \\
\text { Distribuição (CBD), e a segunda empresa, Carrefour, cresceram respectivamente } 4,75 \% \text { e } 3,5 \% \text {, nominalmente. } \\
\text { Dentre as } 20 \text { primeiras empresas, há exemplos como o da rede Gimenes, do interior de São Paulo, que obteve } \\
\text { variação de } 32 \% \text { no faturamento, com abertura de lojas, bem como a rede Y. Yamada, do Pará, com crescimento } \\
\text { de } 16,4 \% \text {, entre outros bons exemplos de performances em } 2005 \text {. (Veja reportagem "Movimentação das } 50 \\
\text { maiores", nesta edição.) }\end{array}$} \\
\hline \multicolumn{3}{|c|}{ Análise da Informação } \\
\hline \multicolumn{3}{|c|}{$\begin{array}{l}\text { As cinco primeiras empresas do setor tem } 40 \% \text { de participação fo faturamento } \\
\text { total. }\end{array}$} \\
\hline \multirow[t]{2}{*}{ Temas } & & Atores \\
\hline & & \\
\hline \multicolumn{3}{|l|}{ URL da fonte } \\
\hline & & \\
\hline
\end{tabular}




\section{5}

\begin{tabular}{|c|c|c|}
\hline \multicolumn{3}{|c|}{ Gestores - Matéria de capa da SuperHiper de Junho de 2006} \\
\hline Fonte & Data de Publicação & Data de Rastreamento \\
\hline SuperHiper & \multirow{2}{*}{$06 / 2006$} & 04/08/2006 \\
\hline \multicolumn{2}{|c|}{ Informação Essencial } & \\
\hline \multicolumn{3}{|c|}{$\begin{array}{l}\text { Gestores } \\
\text { A empresa vem em um processo de reestruturação, com fechamento em } 2005 \text { de toda a sua operação com a } \\
\text { bandeira de supermercados Champion e incentivo à operação dos hipermercados, seu principal formato de loja } \\
\text { desde que chegou ao País, na década de } 80 \text {. O Carrefour abrirá mais } 16 \text { unidades somente este ano, com a } \\
\text { contratação de } 4 \text { mil funcionários. Este aporte nos negócios deve servir para a rede se manter na segunda posição } \\
\text { no Ranking do País, já que sua distância entre o terceiro colocado, o norte-americano Wal-Mart, está na faixa de } \\
6,5 \% \text {. Mas a companhia investe em outra estratégia especial para manter sua evolução no País e ampliar suas } \\
\text { vendas, o relacionamento como instrumento de motivação de seus funcionários, para obter melhores índices de } \\
\text { eficiência e boa percepção por parte do consumidor. Para isso, viabiliza essa idéia por meio dos seus gestores. }\end{array}$} \\
\hline \multicolumn{3}{|c|}{ Análise da Informação } \\
\hline \multicolumn{3}{|c|}{$\begin{array}{l}\text { Com o fechamento da sua rede Champion, o Carrefour conseguiu um aporte que permitirá } \\
\text { manter-se na segunda posição no Ranking ABRAS, no país. Divulga que tem planos de } \\
\text { abertura de mais } 16 \text { unidades. }\end{array}$} \\
\hline \multirow[t]{2}{*}{ Temas } & & Atores \\
\hline & WM, & \\
\hline
\end{tabular}


66

\begin{tabular}{|c|c|c|}
\hline \multicolumn{3}{|c|}{ Pão de Açucar muda direção executiva } \\
\hline Fonte & \multirow{2}{*}{$\begin{array}{r}\text { Data de Publicação } \\
26 / 04 / 2006\end{array}$} & Data de Rastreamento \\
\hline Site APAS & & \\
\hline \multicolumn{3}{|c|}{ Informação Essencial } \\
\hline \multicolumn{3}{|c|}{$\begin{array}{l}\text { O Grupo Pão de Açúcar muda sua diretoria-executiva. Na próxima semana, Rodolfo Landim, ex-presidente da } \\
\text { BR Distribuidora, assume o cargo de diretor-executivo comercial de não-alimentos da rede. A contratação está } \\
\text { confirmada e Landim tem a missão de ampliar a participação nos resultados da área de não-alimento, que inclui } \\
\text { postos de combustíveis. } \\
\text { Dentro da área, que será dirigida pelo executivo, estão também as seções de eletrônicos e eletroportáteis, } \\
\text { informática, têxteis, bazar, drogarias e comércio eletrônico, um total de } 40 \text { mil itens. No ano passado, essa área } \\
\text { por completo respondeu por } 24 \% \text { do faturamento de } \$ \$ 16,1 \text { bilhões do Grupo. } \\
\text { O Grupo deve investir cerca de } R \$ 935 \text { milhões, ainda este ano, para a abertura de novas lojas, postos de } \\
\text { gasolina, drogarias e aquisição de terrenos, reformas e manutenção de ativos. Entre } 2006 \text { e } 2007 \text { a rede vai abrir } \\
\text { cerca de } 20 \text { hipermercados e de } 40 \text { a } 60 \text { supermercados. }\end{array}$} \\
\hline \multicolumn{3}{|c|}{ Análise da Informação } \\
\hline \multicolumn{3}{|c|}{$\begin{array}{l}\text { Pão de Açúcar quer ampliar a participação nos resultados da área de não-alimento, que } \\
\text { inclui postos de combustíveis. Serão feitos investimentos de } R \$ 935 \text { mi, ainda em } 2006 \text { com } \\
\text { finalidade de expansão orgânica e diversificação. }\end{array}$} \\
\hline \multirow[t]{2}{*}{ Temas } & & Atores \\
\hline & PA & \\
\hline \multicolumn{3}{|l|}{ URL da font } \\
\hline \multicolumn{3}{|c|}{ thttp://www.apas.co } \\
\hline
\end{tabular}


67

\begin{tabular}{|c|c|c|}
\hline \multicolumn{3}{|c|}{ Uma chave para crescer } \\
\hline Fonte & Data de Publicação & Data de Rastreamento \\
\hline SuperVarejo APAS & $01 / 2006$ & 22/08/2006 \\
\hline \multicolumn{3}{|l|}{ Informação Essencial } \\
\hline \multicolumn{3}{|c|}{$\begin{array}{l}\text { A desmobilização de capital é uma valiosa estratégia para as redes supermercadistas, que buscam acelerar sua } \\
\text { expansão e aumentar a competitividade. } \\
\text { Outra forma de desmobilização de capital bastante comum é a anunciada em } 2005 \text { pelo Grupo Pão de Açúcar, } \\
\text { com o objetivo de obter recursos para financiar uma arrancada expansionista. A companhia se desfez da } \\
\text { propriedade de } 60 \text { imóveis onde opera suas lojas, permaneceu neles na condição de locatária, e utilizou o valor } \\
\text { da transação - cerca de R } \$ 1 \text { bilhão - para zerar seu endividamento e captar novas dívidas em melhores condições } \\
\text { financeiras. "É parte da engenharia do varejo", observou Abílio Diniz, presidente do conselho de administração } \\
\text { da companhia, à época do anúncio da operação. "A desmobilização possibilita reformas e abertura de novas } \\
\text { lojas. Ter dinheiro parado não adianta", afirma Paulo Pompílio, assessor de comunicação do Pão de Açúcar. }\end{array}$} \\
\hline \multicolumn{3}{|c|}{ Análise da Informação } \\
\hline \multicolumn{3}{|c|}{$\begin{array}{l}\text { O Grupo Pão de Açúcar desfez-se de } 60 \text { imóveis onde opera suas lojas, com o objetivo de } \\
\text { obter recursos para financiar uma arrancada expansionista, cerca de } R \$ 1 \text { bilhão - para } \\
\text { zerar seu endividamento e captar novas dividas em melhores condiçôes financeiras. }\end{array}$} \\
\hline \multirow[t]{2}{*}{ Temas } & \multirow{2}{*}{\multicolumn{2}{|c|}{ Atores }} \\
\hline & & \\
\hline
\end{tabular}


68




This document was created with Win2PDF available at http://www.win2pdf.com.

The unregistered version of Win2PDF is for evaluation or non-commercial use only.

This page will not be added after purchasing Win2PDF. 